\author{
UNIVERSIDADE DE SÃO PAULO \\ ESCOLA DE COMUNICAÇÕES E ARTES \\ PROGRAMA DE PÓS-GRADUAÇÃO EM CIÊNCIA DA INFORMAÇÃO
}

SILVANA DA SILVA ANTONIO ARDUINI

Rubens Borba de Moraes e a institucionalização da

Biblioteconomia no Brasil: uma questão político-cultural

SÃO PAULO

2021 


\section{Rubens Borba de Moraes e a institucionalização da Biblioteconomia no Brasil: uma questão político-cultural}

Versão Corrigida (versão original disponível na Biblioteca da ECA/USP)

Tese apresentada ao Programa de Pós-Graduação em Ciência da Informação, da Escola de Comunicações e Artes da Universidade de São Paulo, como requisito parcial à obtenção do título de Doutor em Ciência da Informação.

Área de concentração: Cultura e Informação

Linha de pesquisa: Apropriação Social da Informação

Orientação: Prof. Dr. Edmir Perrotti

SÃO PAULO 
Autorizo a reprodução e divulgação total ou parcial deste trabalho, por qualquer meio convencional ou eletrônico, para fins de estudo e pesquisa, desde que citada a fonte.

Catalogação na Publicação

Serviço de Biblioteca e Documentação

Escola de Comunicações e Artes da Universidade de São Paulo

Dados inseridos pelo(a) autor(a)

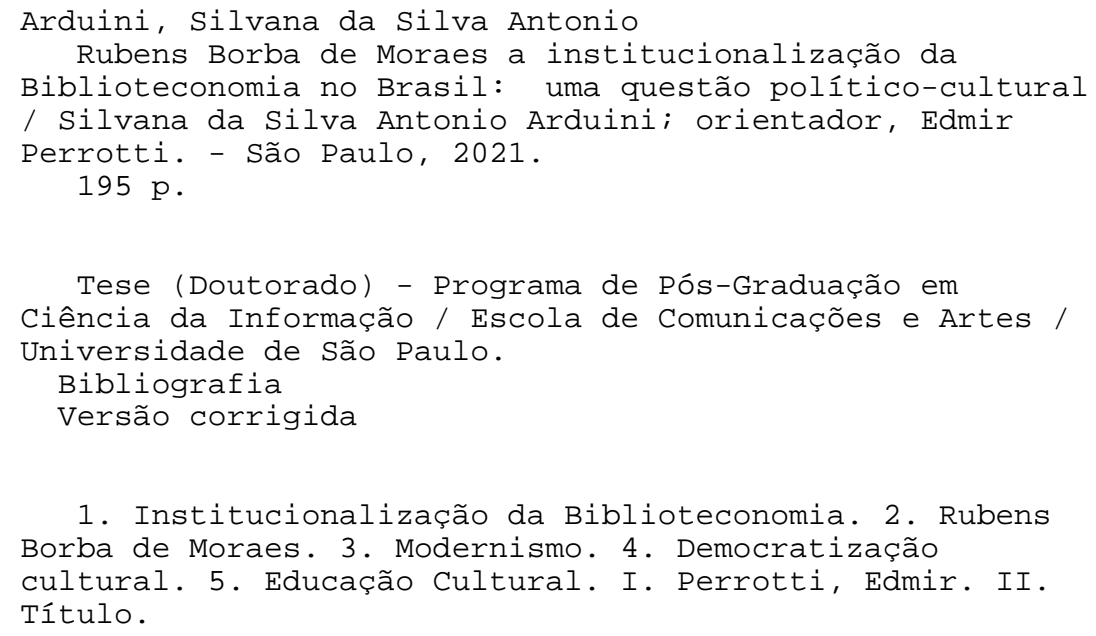

CDD 21.ed. - 020 
Nome: Silvana da Silva Antonio Arduini

Título: Rubens Borba de Moraes e a institucionalização da Biblioteconomia no Brasil: uma questão político-cultural

Tese apresentada ao Programa de Pós-Graduação em Ciência da Informação da Escola de Comunicações e Artes da Universidade de São Paulo para obtenção do título de Doutor em Ciência da Informação.

Avaliação em: 23/07/2021 Conceito: Aprovada com recomendação de publicação

Banca Examinadora

Prof. Dr. Edmir Perrotti (Orientador)

Instituição: PPGCI/ECA/USP

Profa. Vânia Mara Alves Lima

Instituição: PPGCI/ECA/USP

Julgamento: APROVADA

Prof. Oswaldo Francisco de Almeida Junior

Instituição: PPGCI/UNESP

Julgamento: APROVADA

Prof. Fabrício José Nascimento da Silveira

Instituição: PPGCI/ECI/UFMG

Julgamento: APROVADA

Profa. Valéria Martin Valls

Instituição: FESPSP

Julgamento: APROVADA

Profa. César Pereira

Instituição: Puc-Campinas

Julgamento: APROVADA 
Dedico este trabalho a Guilherme Arduini, minha melhor metade, e a Santiago Arduini, filho primogênito de um Amor. 


\section{AGRADECIMENTOS}

Sempre que tomava nas mãos um novo texto acadêmico, corria logo para as páginas "Agradecimentos". Não sei ao certo o que me levava a fazer isso; o que posso afirmar de "sopetão" é que com certeza não foi essa a instrução que recebi nas aulas de Biblioteconomia. Algumas perguntas surgem em minha mente quando tento entender este comportamento: seria uma tentativa de aproximar minhas experiências à concretude de um texto acadêmico? Seria a necessidade de reafirmar cotidianamente para mim mesma de que o trabalho acadêmico não é um trabalho solitário, nem no que diz respeito à estrutura necessária para concretizá-lo, nem no que tange à construção reflexiva em torno do objeto? Seja qual for a motivação que me levou a este comportamento, o fato é que agora chegou a minha vez de deixar o sentimento rolar por minhas mãos nesta parte da tese intitulada "Agradecimentos".

Quero agradecer a Deus em sua manifestação concreta por meio das pessoas que estiveram comigo ao longo dessa jornada e em nenhum momento soltaram a minha mão. Ao mestre Edmir Perrotti; sua sabedoria e gentileza me animaram e animam na caminhada. Agradeço ao Guilherme Arduini, companheiro de jornada. "Gui, não cabe em palavras a gratidão que vivencio por sentir a serenidade que você vibrou ao longo dessa jornada. Gui, minha eterna gratidão pelo companheirismo, dedicação e cuidado com nossos projetos de vida num momento em que minha mente estava voltada para meu projeto acadêmico, e que além de cuidar das "nossas coisas" ainda teve a disponibilidade de ler e discutir o texto da tese". Ao Santi (Santiago Arduini), agradeço seu olhar revigorante e sincero sobre a beleza da vida, mesmo quando estávamos imersos na saudade. Agradeço à minha mãe (Edileusa Antonio), fonte de inspiração de vida e fortaleza - companheira de jornada em dois partos, e ao meu pai (Aparecido J. Antonio), sempre sensível às minhas necessidades, antes mesmo que eu pedisse socorro. À minha irmã Cris (Cristiane Antonio), pelas palavras de ânimo e carinho sempre, sempre presentes. Ao Claudio Jânio, constantemente interessado e animado por acompanhar todo o processo. À querida Zilda Santesso (in memorian), que hoje intercede por minha família nos braços do Pai; jamais esquecerei tudo o que você fez por mim e por minha família. À Brenda Carranza, amiga querida com quem tive proveitosas e animadoras conversas ao longo dessa jornada. Ao Onivaldo Arduini e à Eva Arduini, que participaram do processo de entrada para o doutorado com ânimo, compreensão e cuidado.

Ao longo da jornada, construí amizades que espero cultivar para além da vida acadêmica. À querida Ana Regina Lacerda, com quem aprendi a importância da pesquisa documental, recebi indicações bibliográficas e compartilhei discussões sobre descobertas e 
referências. À Lilian Viana, com quem tive trocas de leituras e compartilhei desafios e alegrias da vida acadêmica. Ao empático Wellington Oliveira, que me ajudou com informações acadêmicas, bibliografia e a leitura técnica desta tese. À Fernanda Passamai, com quem compartilhei descobertas, alegrias e frustrações dos arquivos. À Vímala Ananda, que me acolheu em encontros periódicos que me ajudaram a me encontrar dentro do processo de escrita da tese. À Andreína Virginio, a amiga incentivadora que me ajudou a entrar no GPEC e conhecer de perto o professor Edmir Perrotti. À Maureen Alfinger e à Katia Fugisawa provocadoras do meu lado feminino no meio acadêmico. À Suelena Bandeira, que gentilmente se dispôs a colaborar com a tese e me enviou cópia de sua dissertação e também de documentos relacionados a Rubens Borba de Moraes. À Maria Solange Ribeiro, que me possibilitou acesso à sua biblioteca para que eu pudesse continuar a pesquisa apesar da indisponibilidade de obras nas bibliotecas.

Aos professores Briquet de Lemos e Plínio Martins Filho pelas conversas e envio de informações e materiais que muito contribuiu para que eu pudesse alinhavar a tese. Ao professor Oswaldo Francisco de Almeida Junior e à professora Vânia Mara Alves Lima, que compuseram a banca de qualificação, e, além disso, dispuseram de tempo e informações em conversas informais que facilitaram o percurso metodológico da pesquisa.

Agradeço aos amigos Wellington Gomes (DF), Lea Macedo Dias (RJ) e Lize Roy (Quebec) que disponibilizaram o conforto de seu lar para que eu pudesse realizar parte da pesquisa. Também aos professores Max Butlen e Madeleine Butlen (França), que me acolheram em sua casa com carinho e cuidado. Ao professor Max, em especial por ter ampliado, em tão pouco tempo, a visão que eu tinha sobre a construção de uma pesquisa científica. À Sylvie, que me acolheu no Foyer du Dome, em Paris, durante minha estadia de estudos na França.

Aos colegas do GPEC, com os quais pude participar de ricas discussões que moldaram meu olhar sobre o objeto desta pesquisa, em especial à professora Ivete Pieruccini, que me acolheu como monitora PAE em duas disciplinas e me apresentou a Biblioteconomia sob uma vertente crítica.

Agradeço também aos profissionais que aqueceram minha estadia em arquivos, às vezes gélidos pelo descaso dos poderes públicos, e tomaram os problemas com que me deparei ao longo da pesquisa como "próprios". À Ana Regina Lacerda do Arquivo Histórico da Universidade de Brasília; À Francis Lee do Instituto Hercule Florence; À Mirna do CMU da Unicamp; à Telma do Siarq da Unicamp; À Norma Haru (in memorian) da Biblioteca Mário de Andrade. 
Minha gratidão àqueles que mediaram minha entrada e pesquisa nos arquivos: Emanuel G. F. Guedes e Elisangela Alves Silva (Biblioteca Mário de Andrade); à professora Valéria Valls da FESPSP e ao Winderson Gomes do Cedoc da FESPSP; ao Anderson Gomes e Karina Barros do Arquivo Histórico do Mackenzie; à Eliane do Arquivo Rubens Borba de Moraes da Biblioteca Brasiliana Guita e José Mindlin (BBM); à Denise do Serviço de Arquivo do Instituto de Estudos Brasileiros (IEB); ao Antônio da Biblioteca Monteiro Lobado; à Rubenira da Academia Paulista de Letras; à Ana Virginia Pinheiro da Seção de Obras Raras da Biblioteca Nacional. Também aos funcionários da Academia Brasileira de Letras, aos funcionários da Fundação Getúlio Vargas, aos funcionários da Biblioteca Mário de Andrade, aos funcionários da Biblioteca Nacional da França e aos funcionários da Biblioteca da Universidade Humboldt, em Berlim.

A Geraldo Faccó Vidigal, que gentilmente relatou suas experiências com o Rubens Borba de Moraes e sua família, a "família adotiva" de RBM. À Cristina Antunes, que animou a jornada com relatos de sua experiência pessoal com Moraes. Ao Maurício Trindade do Centro de Formação do SESC, que indicou atividades e bibliografias para que eu pudesse realizar a pesquisa documental.

Aos funcionários do programa de Pós-Graduação em Ciência da Informação, Isabela e Bruno, que mediaram os trâmites burocráticos e que muitas vezes se deixaram conduzir pela empatia em relação às demandas que eu trazia. Aos professores do PPGCI da ECA, que indiretamente participaram da construção teórica ou metodológica desta pesquisa. Agradecimento especial ao professor Marivalde Moacir Francelin e à Cibele Araújo C. M. dos Santos, que continuaram a mostrar interesse sobre minha pesquisa no momento em que eu gerava outra vida. Aos funcionários da biblioteca da Escola de Comunicações e Artes.

Aos funcionários da Biblioteca de Educação da Unicamp, em especial à Rosemeire Passos e à Simone Lucas Gonçalves, que cuidaram de minha longa estadia na biblioteca, fornecendo inclusive acesso como pesquisadora. À amiga Lurdes Pontel da Biblioteca Central da Unicamp, pelas inúmeras buscas de artigos "impossíveis" de localizar e pelas conversas "espairecedoras" depois das longas jornadas de trabalho.

À Laura Antonio, que dedicou dias na organização do meu Mendeley. A Laudemir Merlini pela revisão gramatical desta tese e a Wellington de Oliveira pela formatação deste trabalho.

À Coordenação de Aperfeiçoamento de Pessoal de Nível Superior (Capes), que financiou parte significativa desta pesquisa (incluindo o meu período de licença maternidade); auxílio sem o qual não seria possível a realização desta. Nesse sentido, deixo registrada a 
importância de contar com este incentivo essencial, especialmente para que mulheres possam participar "em pé de igualdade" da construção científica nacional.

A todos aqueles que indiretamente colaboraram com a concretização desta tese, o meu muito obrigada! 
"Fora do outono certo, nem as aspirações amadurecem".

(MEIRELES, 1984, p. 15) 


\section{RESUMO}

Trata da institucionalização da Biblioteconomia no Brasil, como campo político-cultural, empenhado na modernização do país, no século XX. Analisa ações e concepções inscritas nos projetos do bibliófilo, bibliógrafo e bibliotecário Rubens Borba de Moraes, membro ativo de circuitos modernistas brasileiros. Figura emblemática de um amplo movimento políticocultural nacional e internacional. Moraes exemplifica a luta e as contradições da afirmação da cultura letrada, no país. O trabalho apresenta resultados de pesquisas documentais em arquivos pessoais e administrativos, destacando seus planos e ações na direção da Divisão de Bibliotecas, do Departamento de Cultura e Recreação, da Prefeitura de São Paulo, em 1935. Outras ações comprovadoras de um trabalho consciente da importância da definição e afirmação de um campo biblioteconômico, definidas por critérios político-culturais modernos que incluem, mas não priorizam a técnica, também são discutidas. Assim, é analisada a participação ativa de Moraes na criação da Associação Paulista de Bibliotecários, na promulgação de legislação que define a profissão de bibliotecário/a, em São Paulo. Além da institucionalização do campo, estava em causa a luta por uma direção representada por Moraes: a da Biblioteconomia como um campo político-cultural, comprometido, no caso, com o projeto de modernização e de (re)afirmação identitária. Os vínculos com o modernismo deixaram marcas que o tempo e as disputas do campo, no país e fora dele, foram redesenhando.

Palavras-chave: Institucionalização da Biblioteconomia; Rubens Borba de Moraes; Modernismo; Democratização cultural; Educação cultural. 


\begin{abstract}
This thesis deals with the institutionalization of Librarianship in Brazil, understood as a cultural and political field, committed to the modernization of the country in the XXth century. It analyses actions and concepts inscribed in projects by the bibliophile, bibliographer and librarian Rubens Borba de Moraes, an active member of Brazilian modernist circuits. An emblematic character of a wide (in national and international scale) cultural and political movement that incorporates and extrapolates himself, Moraes exemplifies the struggle for the spread of literate culture and the contradictions of its affirmation in Brazil. This research presents the results of document analysis in personal and institutional archives, highlights his plans and actions while he was the director of the Library Division ("Divisão de Bibliotecas") from the Culture and Leisure Department ("Departamento de Cultura e Recreação") of São Paulo city's municipal administration ("Prefeitura de São Paulo") in 1935. Other actions discussed in the thesis involve demonstrations of a conscious plan to shape and affirm a Librarianship field, defined by political and cultural modern criteria that include, but do not prioritize, its technical aspects. Therefore, we analyse the implementation of Librarianship courses that will introduce precepts of Modern Librarianship among Brazilians, as well as Moraes' active participation in the foundation of São Paulo's Librarians Association and in the promulgation of a legislation that defines the profession of Librarian, in São Paulo State. His time as the Head of National Library is also studied, taken as an evidence of broader concerns of his age with the spreading of the Librarianship field in the country. Moraes produces, discusses and disseminates his ideas throughout his publications, interviews and active participation in professional events, as attested in academic journals and unpublished materials. His links with foreign institutions are shown as evidence that the Brazilian librarianship project is stuck onto a national and international panorama of post-colonial and cultural modernization. Beyond the institutionalization of the field, it was at stake the struggle for a postulation assumed by Moraes: Librarianship understood as a cultural political field, committed, in this case, to the project of modernization and identity (re)affirmation. His bonds to the modernist cultural movement left marks reshaped by time and arguments inside the field.
\end{abstract}

Keywords: Librarianship institutionalization; Rubens Borba de Moraes; Modernism; Cultural Democratization; culture learning. 


\section{RESUMEN}

El trabajo trata de la institucionalización de la Biblioteconomía, como campo político-cultural, empeñado en la modernización del país, en el siglo XX. Analisa acciones y concepciones inscriptas en proyectos del bibliófilo, bibliógrafo y bibliotecario Rubens Borba de Moraes, miembro activo de grupos modernistas brasileños. Figura emblemática de un amplio movimiento político-cultural nacional e internacional que incluye y sobrepasa, Moraes ejemplifica la lucha y las contradicciones de la afirmación de la cultura letrada, en el país. El trabajo presenta resultados de investigaciones documentales en archivos personales y administrativos, destacando sus planes y acciones en el puesto de director de la "Divisão de Bibliotecas", del "Departamento de Cultura e Recreação", de la Municipalidad de São Paulo. $\mathrm{Su}$ trabajo como director de la Biblioteca Nacional es abordado, con evidencia de preocupaciones generales de la época con la ampliación del campo biblioteconómico, en el país. Moraes produce, discute y disemina ideas, como prueban publicaciones, charlas, entrevistas y su participación frecuente en eventos del área. Sus relaciones con otros países son expuestas con indicio de que el proyecto biblioteconómico brasileño se insertó en un panorama nacional e internacional de modernización cultural del Poscolonialismo. Además de la constitución del campo, estaba aun en causa la lucha por una dirección representada por Moraes: la de la Biblioteconomía como un campo político-cultural comprometido, en este caso, con el proyecto de modernización y reafirmación de una identidad. Los vínculos con el Modernismo han dejado huellas que el tiempo y las disputas del campo, en el país y fuera de él, fueron rediseñando.

Palabras clave: Institucionalización de la Biblioteconomía; Rubens Borba de Moraes; Modernismo; Democratización cultural; Educación cultural. 


\section{LISTA DE SIGLAS}

ABL Academia Brasileira de Letras

ALA American Library Association

APB Associação Paulista de Bibliotecários

APL Academia Paulista de Letras

CMU Centro de Memória da Unicamp

FUP $\quad$ Frente Única Paulista

IBBD Instituto Brasileiro de Bibliografia e Documentação

MES Ministério da Educação e Saúde

OCIAA Coordinator of Inter-American Affairs

PD Partido Democrático de São Paulo

RBM Rubens Borba de Moraes RBM

UDF Universidade do Distrito Federal

UNICAMP Universidade de Campinas 


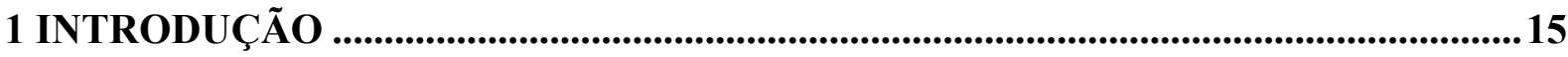

1.1 Biblioteconomia na literatura brasileira ...........................................................20

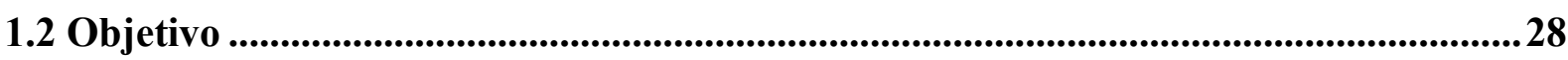

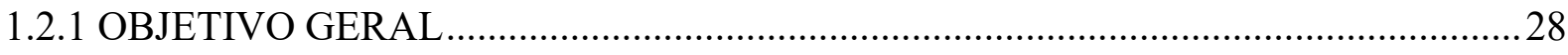

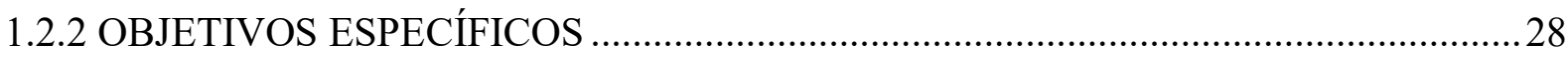

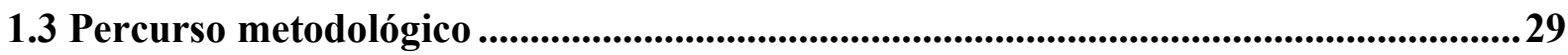

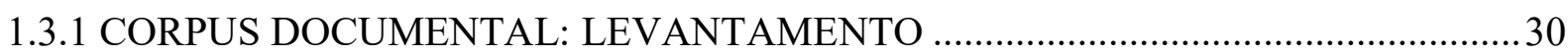

1.3.2 CORPUS DOCUMENTAL: TRATAMENTO, SELEÇÃO E ANÁLISE ......................33

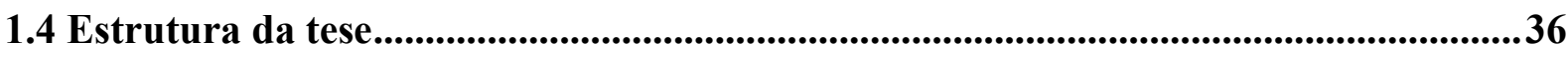

2 UMA BIBLIOTECONOMIA EMPENHADA........................................................38

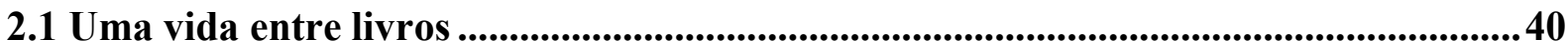

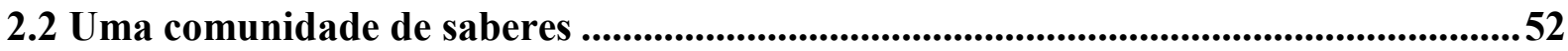

2.3 Ingresso no universo da difusão cultural.............................................................54

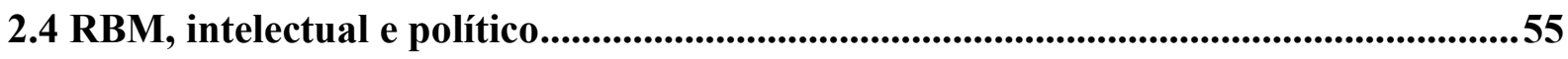

2.5 Da bibliofilia à "ordem dos livros" .........................................................................58

2.6 O bibliotecário modernista: conhecimento em ação ................................................61

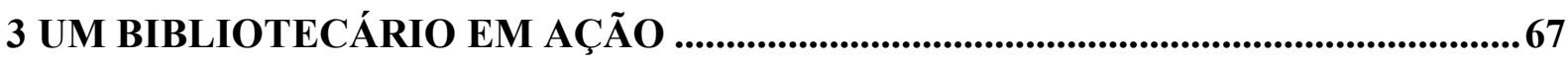

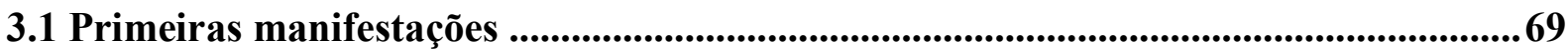

3.2 Preâmbulos da Divisão de Bibliotecas ........................................................................75

3.3 Na Divisão de Bibliotecas: projetos e disputas........................................................82

3.40 projeto........................................................................................................................................85

4 FORMAÇÃO DE UM BIBLIOTECÁRIO PARA UMA TEIA BIBLIOTECÁRIA....97

4.1 O discurso inaugural de Rubens .........................................................................97

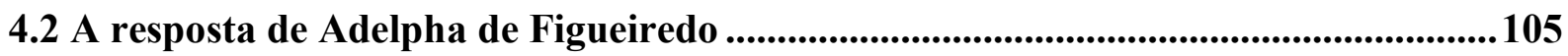

4.3 Rubens Borba de Moraes, professor na Escola de Biblioteconomia: entre a técnica e

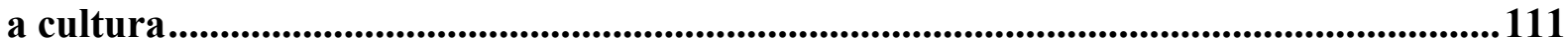

4.4 Aprendizados de um processo ...............................................................................120

5 UM BIBLIOTECÁRIO MODERNISTA - A BUSCA DE RECONHECIMENTO E AFIRMAÇÃO DA BIBLIOTECONOMIA BRASILEIRA ........................................129

5.1 A Biblioteconomia no Legislativo e o Conselho Bibliotecário ..................................129

5.2 Associação Paulista de Bibliotecários (APB) e a publicação de materiais sobre

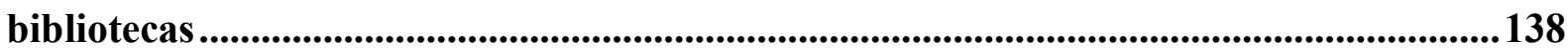


5.3 A Escola de Biblioteconomia vai para a Escola de Sociologia e Política 141

5.4 RBM manifesta sobre "O problema das bibliotecas brasileiras" 148

5.5 Moraes assume a Biblioteca Nacional........................................................................153

5.6 Nem “clássica", nem "moderna": “empenhada" e "antropofagista" ..........................156

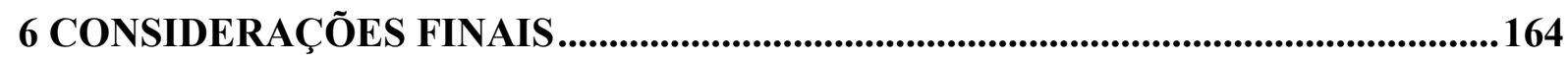

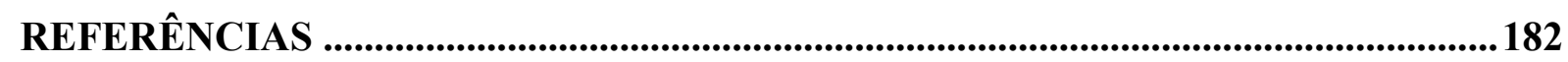




\section{INTRODUÇÃO}

As "sociedades em rede" (CASTELLS, 2005) acrescentaram novas questões a problemáticas clássicas envolvendo as instituições culturais, dentre elas, as bibliotecas. O arcabouço conceitual e metodológico construído historicamente em torno dessas instituições foi abalado de tal forma que vozes pouco cautelosas chegaram a pôr em dúvida, num mundo dominado por tecnologias de informação e comunicação altamente performáticas, a importância sociocultural de bibliotecas ${ }^{1}$. Afirmações de tal teor, feitas muitas vezes no calor da hora, encontraram, evidentemente, resistências de outras vozes e da própria realidade, nos mais diferentes países, especialmente naqueles com tradição significativa nas esferas da cultura e da educação.

No Brasil, todavia, o abalo produzido pela emergência da "era da informação" vem representando, muitas vezes, descontinuidades e, inclusive, cortes abruptos, sobretudo em áreas que só tardia e lentamente se constituíram como campo ${ }^{2}$ sociocultural e epistêmico, como a da Biblioteconomia, criação do nosso século XX.

Nesse sentido, diferentemente de sociedades onde instituições culturais como as bibliotecas se desenvolveram e tiveram condições para consolidar-se, fomos surpreendidos pela emergência inapelável da nova ordem cultural contemporânea, sem termos elementos teóricos e práticos que nos permitissem responder de modo afirmativo às inúmeras perplexidades que nos tomam de assalto.

Sem sistemas efetivos e robustos consolidados de memória social organizada, a "cultura da informação" (LE DEUFF, 2010; SERRES, 2014) não tem possibilidade de se constituir como tal, correndo o risco de tornar-se apenas fenômeno de acumulação caótica de signos, desprovidos de sentidos. Memória e informação são, funcionalmente e cada uma a seu modo,

\footnotetext{
${ }^{1}$ Em 2018, o economista americano Panos Mourdoukoutas publicou na página da Forbes um artigo que dizia que a biblioteca e seus serviços poderiam ser substituídos pelos serviços e lojas da Amazon. O texto foi retirado do ar sob a alegação de que o tema "biblioteca" não estava no escopo de especialidade do autor, que é professor na área de Economia. Para mais informações sobre o artigo, que teve repercussão mundial, ver: GRADY, C. Why public libraries are still essential in 2018: libraries exist for the public. Amazon exists to maximize profits. Vox, Washington, D.C., 24 jul. 2018. Disponível em: https://www.vox.com/culture/2018/7/24/17603692/publiclibraries-essential-forbes-amazon. Acesso em: 13 out. 2020.

${ }^{2}$ Neste trabalho, campo é entendido como espaço de relações políticas, sociais, intelectuais e culturais circunscritos, que não é neutro, ao contrário, é definido por interesses, conflitos e lutas de diferentes ordens (BOURDIEU, 1983; BOURDIEU; WACQUANT, 1992); campo compreende um conjunto de instituições, práticas, ações e processos que vão desde a formação de comunidades de pares até a produção intelectual e/ou artística. Bourdieu define "campo" como um microcosmos social regido por lógicas próprias, como se vê na seguinte passagem: "O cosmos social é constituído pelo conjunto desses microcosmos sociais relativamente autônomos, espaços de relações objetivas que são o lugar de uma lógica e de uma necessidade específicas e irredutíveis àquelas que regem os outros campos" (BOURDIEU; WACQUANT, 1992, p. 73).
} 
contrapartidas necessárias e imprescindíveis uma da outra (OLIVEIRA, 2010). O risco da “desinformação" nos assola, tendendo a agravar-se na medida em que instituições de memória, como as bibliotecas, os museus, os arquivos, não sejam devida e efetivamente revisitadas, repensadas, redimensionadas na ordem social brasileira.

Desse modo, é de especial importância enfrentarmos questionamentos como os mencionados e levantados em diferentes fóruns: em que medida bibliotecas continuariam sendo um equipamento essencial às dinâmicas culturais, aos processos de apropriação de conhecimento e cultura, no Brasil e no mundo atual? As novas configurações tecnológicas seriam capazes de ocupar e preencher com maior eficácia o lugar dessas instituições cujas origens se perdem em tempos distantes, mas que não conseguiram universalizar-se na sociedade brasileira, nem universalizar práticas culturais que as justificassem e legitimassem, como, por exemplo, o acesso à leitura e à cultura letrada por diferentes categorias sociais?

Para responder a estas perguntas, um recuo ao passado para compreender a institucionalização do campo biblioteconômico no Brasil permite iluminar novos aspectos, demonstrando nossa dificuldade em enfrentar, como sociedade, o desafio de universalizar o acesso à leitura, bem como o direito à cultura letrada, dificuldade histórica e persistente, que se mantém até hoje, herdada de nossa condição colonial.

Nessa tentativa de releitura, buscaremos, assim, rever caminhos traçados pela institucionalização do campo biblioteconômico brasileiro, tomando a figura emblemática do bibliógrafo e bibliotecário Rubens Borba de Moraes (1899-1986) como fio condutor de nosso trabalho, seja porque Moraes viveu intensamente as questões culturais e bibliotecárias no Brasil e no exterior, seja porque seus projetos estão articulados com as grandes questões políticoculturais do país, participante privilegiado e atuante que foi nos circuitos modernistas paulistanos e nacionais e cujos membros acreditavam na possibilidade de superação das fraturas culturais deixadas pela sistema colonial, no país, a partir de ações localizadas em torno de suas esferas de interesse. No caso de Rubens, a cultura letrada e seus objetos privilegiados - os livros brasileiros (CASTRO, 2000; FREYRE, 1943³; LEMOS, 1983, 2014, 2016; RUSSO, 1966; SOUZA, 2003)

\footnotetext{
${ }^{3}$ O texto de Freyre (1943) é um artigo publicado no jornal Diário de S. Paulo por ocasião da dispensa de Moraes da Divisão de Bibliotecas do Departamento de Cultura. Trata-se de um protesto diante da política assumida por Prestes Maia, prefeito da cidade de São Paulo. Cf. FREYRE, G. Um bibliotecário. In: FONSECA, E. N. da. Introdução à Biblioteconomia. São Paulo: Pioneira, 1992.

${ }^{4} \mathrm{O}$ reconhecimento internacional de Rubens Borba de Moraes como bibliotecário influente na história da Biblioteconomia brasileira pode ser visto em QUINN, M. E. Historical dictionary of librarianship. Rowman \& Littlefield, 2014.
} 
A escolha de Moraes oferece-nos também a oportunidade de releitura de lugares comuns prevalentes na área e que continuam a turvar a compreensão de questões envolvendo o campo, como a falsa dicotomia entre Biblioteconomia técnica e humanística. Ao contrário do que afirma ligeiramente a literatura a respeito, que posiciona Moraes como um defensor da técnica, buscaremos demonstrar que sua abertura para repensar as técnicas vigentes no Brasil, a partir da experiência bibliotecária estadunidense, notadamente a classificação decimal de Dewey, é um aspecto atrelado aos projetos político-culturais de modernização do país e que requeriam uma concepção de Biblioteconomia Moderna. Em oposição à Biblioteconomia Clássica, centrada na preservação patrimonial, a outra valoriza a circulação e os usos dos documentos, condição que demanda sistemas de recuperação documentária especialmente elaboradas mediante técnicas de organização que visam a disseminação dos registros que constituem a chamada memória social.

A trajetória de Moraes aponta, também, para reflexões sobre o que deveria ser a biblioteca e o bibliotecário no Brasil, tomando inicialmente a Pauliceia dos anos 1930 como campo de experimentação; ação ampliada com um intenso trabalho militante de profissionalização da categoria, desconhecida até então, como tal. Ele estará à frente da organização de instituições formativas e reguladoras do trabalho bibliotecário, de ações de compartilhamento de suas reflexões, tanto no Brasil, como em congressos da American Library Association (ALA), dos quais participou, por exemplo, em 1939 e 1947.

É mister esclarecer, neste ponto, conceitos e elementos históricos mobilizados para que se compreenda o teor desta tese. Iniciaremos pelo bourdieusiano de campo, conforme já mencionado, uma vez que este nos permite referir à nossa problemática de uma forma orgânica e não como uma simples sucessão de fenômenos isolados ou diluídos. Com efeito, a partir dos anos 1930, de maneira não linear, o panorama cultural brasileiro toma rumos novos com a era Vargas, instâncias de acesso à atividade socioprofissional de bibliotecário começam a ser definidas e redefinidas em novos termos, assim como as próprias instituições, seus fazeres e objetivos. Consequência disso é a discussão dos sentidos políticos envolvidos nessa ação social abrangente, marcada por princípios e métodos, por teorias e práticas que formarão um corpo de fenômenos que, em conjunto, resultam no campo biblioteconômico brasileiro.

Desse modo, em nossa escolha, consideramos as possibilidades hermenêuticas do conceito de campo que permitem trabalhar analiticamente o objeto em tela nesta tese que, mais do que uma sucessão de fenômenos no tempo e no espaço, pretende apreender um movimento abrangente, dinâmico e especial, articulado a outras esferas da vida social e com as quais está em relações de colaboração e de disputas. 
Por outro lado, o modelo de campo proposto por Bourdieu (1983), especialmente quando se leva em conta as características da atividade profissional bibliotecária já desde os anos 1930, oferece oportunidade de situar a problemática da profissionalização. Ao contrário da perspectiva envolvida por produtores artísticos a que se refere Becker $(2006,2010)$ e que o levou a utilizar o termo mundo (world) enquanto episteme classe bibliotecária, apresenta já nos anos 1930 a novidade de ter critérios objetivos para atuação e de ser ciosa da atribuição de um nível universitário a seu fazer - o que significa um nível que era bastante elevado, especialmente para a época, não só, mas especialmente no Brasil.

A profissionalização dos bibliotecários(as) marcada pela luta por reconhecimento da necessidade de curso superior específico para essa finalidade, foi condição que acabou ocorrendo efetivamente. A isso se soma a existência de ritos bastante marcantes para a profissão, tais como o registro em um conselho profissional, a participação em eventos característicos da área ou, para uma significativa parcela do corpo profissional, o concurso público de admissão, com seu corolário de lutas por uma carreira de cargos e salários normatizada e impessoal.

Estas marcas de pertencimento ao corpo profissional, estimulantes de uma experiência de consciência em comum, poderiam incentivar a aproximação do caso em escrutínio aos estudos marxistas sobre a história dos trabalhadores. Esta foi ampliada no século XX por preocupações com o cotidiano (BOSI, 2003), com os laços de solidariedade mais ou menos informais compreendidos como terreno (BURKE, 2003) das já tradicionalmente estudadas associações profissionais - em resumo, todo o amplo leque de interesses sintetizado na expressão "mundos do trabalho".

Sem prejuízo dos ganhos obtidos por essa literatura, caberia uma reflexão sobre a pertinência de se utilizar o instrumental teórico talhado para a compreensão do universo fabril no caso das bibliotecas brasileiras. É um truísmo lembrar que os bibliotecários brasileiros vivem e trabalham em uma sociedade capitalista; ainda assim, conceitos como "mais-valor", "valor de uso", ou "consciência de classe" explicam apenas em parte o cotidiano das relações dos bibliotecários com o campo em causa. Também parece redutor tratar apenas como "consciência de classe" as intrínsecas relações do corpo profissional com as legislações reguladoras do trabalho; há de fato um componente na constituição do campo bibliotecário que envolve mobilizações em defesa dos interesses de trabalho ${ }^{5}$, mas talvez haja outros aspectos da trajetória

\footnotetext{
${ }^{5}$ Componente extremamente válido e necessário, devemos afirmar, na condição de profissionais em um "terreno"
} (BURKE, 2003) antes ocupado por "bibliotecários tradicionais" (POIRIER, 2001). 
que se aproximam mais do sentido de trabalho na visão weberiana, como uma ética racionalmente organizada com vistas a um fim (WEBER, 1999).

O conceito de campo, na vertente bourdieusiana, é uma das propostas capazes de unificar a análise acumulada pela sociologia do trabalho, no diálogo entre Marx e Weber. Permite trabalhar com conceitos como capital cultural, habitus e illusio $^{6}$ de forma a tornar inteligível um processo histórico cujas transformações visíveis nos anos 1930 são resultantes da emergência de processos históricos iniciados décadas antes.

Em outros termos, como ficará ainda mais evidente no momento da análise das aulas e diálogos entre Rubens Borba de Moraes e outros atores do campo da Biblioteconomia, como Adelpha de Figueiredo, é da união de certos conceitos marxistas com a sociologia weberiana que se extrai a melhor leitura do panorama nacional da emergência da Biblioteconomia como um campo. Por exemplo, dada a importância das leis e normas moduladoras das condições de atuação dos bibliotecários e de como elas foram construídas em negociação com a burocracia estatal, compreender a racionalização burocrática da modernidade somada ao patrimonialismo (FAORO, 2001) da gestão pública brasileira ajuda a entender a atuação dos bibliotecários em todos os âmbitos, mas especialmente na sua interface com o poder público.

Sob esta perspectiva cabe o questionamento: a bandeira da "leitura pública" (BERTRAND, 2010), utilizada no passado por militantes culturais de diversas procedências, mas de natureza análoga, continuaria válida no mundo da cultura digital, com inúmeras possibilidades não só de recepção, mas de produção e de distribuição de signos organizados sob a ordem que rompe com a ordem linear do mundo analógico? As bibliotecas poderiam continuar sendo consideradas como dispositivos culturais indispensáveis aos processos vivos de democracia cultural (CHATZIMANASSIS, 2014a, 2014b) em nosso tempo, especialmente

\footnotetext{
${ }^{6}$ No Vocabulário Bourdieu (2017), Ana Maria Alice Nogueira define capital cultural como: "Os bens econômicos ou financeiros não constituem a única forma de riqueza que fundamenta a divisão da sociedade em classes ou estratos sociais [...] As diferenças relativas às condições materiais de existência se transmutam - por meio de um processo subjetivo de internalização de disposições e de competências - em diferenças no estilo de viver, isto é, na maneira de se usufruir os bens materiais possuídos, engendrando distinções simbólicas entre os indivíduos ou, em outras palavras, distinções relativas à posse de bens culturais". Por analogia ao pensamento de Marx sobre o processo de acumulação dos recursos materiais nas mãos de um determinado grupo social, Bourdieu toma-lhe de empréstimo o termo "capital", acoplando-o ao qualificativo "cultural", para deixar bem claro que se trata de uma outra dimensão da realidade social." (CATANI, 2017, p. 54). Na mesma obra, Loïc Wacquant define habitus como a "noção mediadora que ajuda a romper com a dualidade de senso comum entre indivíduo e sociedade ao captar 'a interiorização da exterioridade e a exteriorização da interioridade', ou seja, o modo como a sociedade se torna depositada nas pessoas sob a forma de disposições duráveis, ou capacidades treinadas e propensões estruturadas para pensar, sentir e agir de modos determinados, que então as guiam nas suas respostas criativas aos constrangimentos e solicitações do seu meio social existente." (CATANI, 2017, p. 214). Já Andréa Aguiar chama atenção para o uso da palavra illusio, tomada de empréstimo do livro de Johan Huizinga sobre o jogo (Homo Ludens), que é uma forma de definir o interesse dos agentes que participam como algo historicamente datado, com significado circunscrito e compartilhado tacitamente entre os participantes, que concordaram em atribuir o mesmo valor ao que está ali em jogo e que por isso adquire importância dentro daquele campo.
} 
em países como o Brasil que não as "descobriram" ainda? Elas não teriam perdido terreno e sido ultrapassadas pelas lógicas e novas sociabilidades de que as tecnologias da informação e comunicação digitais são portadoras?

O diálogo com as décadas de 1930 a 1940, momento em que se inicia efetivamente o processo de institucionalização da Biblioteconomia, como campo socioprofissional, no Brasil, consistirá na tentativa de compreender seu sentido social, político e cultural. Foi nesse momento - este é um dos eixos de sustentação desta tese - que tal fato se adensa e, em consequência, torna-se necessário uma revisita e mergulho nas águas desse tempo, a fim de que possamos apreender dados indispensáveis à compreensão de questões envolvendo bibliotecas e Biblioteconomia no país, na "era da informação".

Nesses termos, está em questão, apreender, perscrutar e interrogar esforços de construção institucional realizados no país, mesmo que lenta e tardiamente, mas que tiveram como objeto de preocupação a constituição de lugares de memória (NORA, 1993), indispensáveis à produção e renovação de conhecimento e cultura. Com os novos tempos globais, que vêm reordenando, às vezes, de modos drásticos, nossas relações com a informação, a memória, a educação, o conhecimento, a cultura, que tomam tais categorias como valor estratégico, definidor de posições a serem ocupadas por cada país no quadro geopolítico internacional, está em causa, portanto, não apenas o destino e a importância de um campo que vimos emergir no século XX, entre nós.

O tratar da emergência do campo da Biblioteconomia, no país, e seus desdobramentos, talvez possa nos fornecer pistas para a compreensão de caminhos passados e presentes da vida nacional, ao mesmo tempo em que poderá nos oferecer elementos para a construção de um futuro renovado, ao se ancorar e entrar em diálogo com as forças vivas e motrizes da história.

\subsection{Biblioteconomia na literatura brasileira}

Ao revisitarmos a literatura sobre a emergência da Biblioteconomia brasileira, verificamos uma frequente rejeição ao modelo de biblioteca patrimonial, de origem antiga e medieval, e que marcou o início da história destas instituições culturais no Brasil (ALMEIDA JÚNIOR, 2000; MARTINS, 1996; MORAES, 1979b; SCHWARCZ, 2000). Esta reação pode ser constatada em publicações contemporâneas e, da mesma forma, em textos que se inscrevem nos esforços de traçar panoramas tendo em vista a constituição e renovação do campo (RUSSO, 1966). Ao mesmo tempo, na tentativa de desfazer a fratura histórica entre biblioteca e sociedade (ALMEIDA JÚNIOR, 1997), a preocupação em criar bibliotecas sob novas perspectivas é 
frequente. Entretanto, o modo como a literatura aborda o processo constitutivo da Biblioteconomia não responde à complexa problemática que envolve, segundo Perrotti (2016), a passagem da biblioteca de conservação (templum) ou de difusão (emporium) para a biblioteca fórum, modalidade em constituição em contextos contemporâneos, segundo posições críticas de paradigmas culturais que presidiram tanto o mundo antigo e medieval, como o moderno.

A literatura biblioteconômica repete com frequência bordões como "Biblioteconomia humanista" versus "Biblioteconomia tecnicista", sem, todavia, penetrar ou questionar a simplificação dualista operada por tal fórmula exemplificada no caso brasileiro, com a contraposição da história dos cursos da Biblioteca Nacional e do Mackenzie. A redução maniqueísta foi facilmente aceita no campo, a ponto de produzir uma espécie de mito fundador de duas cabeças, isto é, uma divisão normativa entre o que Biblioteconomia é ou deveria ser "técnica" ou "ciência", conjunto de procedimentos ou episteme.

Tal binarismo, além de reducionista, levou à produção de um campo narcísico, fechado em sua história interna e evolucionista, sem o devido exame de suas premissas, ambiguidades e ambivalências. A abordagem dicotômica, cujas origens são discursos biblioteconômicos internacionais, aparecem de diferentes modos nos debates brasileiros que discutem, por exemplo, o "modelo francês" versus o "modelo americano", a Biblioteconomia "de São Paulo" versus a Biblioteconomia "do Rio de Janeiro", caminhando a discussão em atalhos que conduzem mais ao provincianismo que a compreensões essenciais e necessárias. Segundo Lemos (2015), o procedimento esconde o fato de que a literatura da área repete com facilidade discursos acríticos, não refletidos, pouco questionadores e menos ainda investigativos, assentados na busca, análise e interpretação de fontes originais.

Isso nos leva a questionar o modo como a Biblioteconomia, ao menos no Brasil, tem se debruçado sobre sua própria história, a fim de compreender as mudanças ocorridas no campo e em seus objetos de estudos teóricos e empíricos. Para Souza (2003), a história da Biblioteconomia, no Brasil, resultou numa única Biblioteconomia, a "Biblioteconomia massificada". Sua crítica destaca a hegemonia de uma Biblioteconomia tecnicista, afinada com tal perspectiva "massificada".

Por outro lado, Lemos (2014) defende a existência de estudos e práticas em múltiplas biblioteconomias (uma patrimonial, outra digital, outra educacional - e, ainda, a "faça-vocêmesmo"). Sem deixar de reconhecer o privilégio que vigora em torno da técnica, conforme apresentado por Souza (2003), compreendemos, todavia, que, para além da técnica e das visões redutoras do campo, há questões essenciais que a incluem e que podem munir-nos de elementos que não foram suficientemente abordados na literatura e nas práticas bibliotecárias. Tais 
elementos, ao serem explorados, poderão produzir resultados importantes para avanços no campo histórico e cultural do país.

Assim sendo, a técnica, entendida como um meio racional usado pela humanidade para atingir determinados fins, será compreendida neste trabalho com base na noção de controle e valor (BRÜSEKE, 2002). Na Biblioteconomia, o controle pode ser visto sob o aspecto do uso das técnicas em função do volume de obras a serem disponibilizadas para o público. E o valor refere-se à importância dada ao uso destas técnicas em detrimento de outros elementos igualmente essenciais ao campo.

Interessa-nos nesta parte do texto reafirmar, portanto, que no nosso entendimento o fato de as técnicas bibliotecárias “modernas" terem chegado ao Brasil simultaneamente ao processo de institucionalização do campo, país, não nos permite criar uma relação de causa e efeito, que se desdobra em uma categorização dualista entre Biblioteconomia humanista e tecnicista. Este tipo de categorização normalmente aparece ancorada no fato de os atores desta importação e da institucionalização serem os mesmos, e, ainda, no fato de a entrada de novas técnicas de classificação e catalogação ter ocorrido via São Paulo e não Rio de Janeiro, onde o histórico de formação de pessoas para trabalhar em bibliotecas é anterior à institucionalização do campo.

Parece-nos demasiado redutor, do ponto de vista do conceito de campo, sistematizar a história da Biblioteconomia pelo uso ou não de técnicas de classificação e catalogação, já que as produções, as relações estabelecidas entre os sujeitos, as ações políticas, as legislações e as formações científicas e profissionais compõem aos poucos, no Brasil, uma trama complexa da Biblioteconomia como espaço profissional e epistêmico. Assim sendo, entendemos que as discussões dualistas reduzem de maneira expressiva a vertente cultural, e ela é também portadora de técnicas inseridas nas ações que foram construindo a institucionalização do campo. Ou seja, fórmulas que a associam ao tecnicismo pragmático ou ao humanismo essencialista e etéreo, desvinculado do mundo (ALMEIDA JÚNIOR, 2000), não são capazes de penetrar nessa trama complexa onde cada elemento contribui para lhe dar vida e fazê-la avançar.

Este trabalho busca entender, assim, as dimensões político-culturais implicadas na origem do campo, o qual deve ser tomado em suas múltiplas dimensões como forma de apreender, a partir de singularidades que lhes são próprias, seu papel na história cultural brasileira e abrir brecha para um novo caminho metodológico que possa contribuir à compreensão da problemática da Biblioteconomia brasileira na contemporaneidade.

Conforme enunciamos anteriormente tomaremos o percurso intelectual de Rubens Borba de Moraes (RBM) como fio condutor da tese. Moraes tinha um projeto político-cultural compartilhado por outros modernistas, tais como Mário de Andrade (São Paulo, 1893-1945) 
e Sérgio Milliet (São Paulo, 1898-1966), do qual a Biblioteconomia era parte. Essa inserção num movimento que o extrapolava permitia-lhe um trânsito cultural que ultrapassava o campo especializado e profissional, elevando a ideia da Biblioteconomia a projeto cultural para o país, associado a outros projetos, implicando outras instituições, dinâmicas, além de atores culturais.

Assim como escreve Miceli (2012) sobre Mário de Andrade, Rubens Borba de Moraes se beneficiou de uma conjunção que agregava "trunfos familiares, requintada escolarização autodidata e livre trânsito com redes de sociabilidade da elite nativa”. (MICELI, 2012, p. 30). Esse traçado social lhe permitia trânsito livre nas instituições de políticas culturais nacionais e nas instituições internacionais da Europa e da América.

Entendemos que acompanhar Moraes em seus trânsitos culturais e sociais nos permitirá, portanto, rastrear certos traços da Biblioteconomia (CASTRO; RIBEIRO, 2004) que estão perdidos em abordagens restritas, conferindo-lhe uma perspectiva ampla e complexa que a situa nos quadros de constituição da história cultural brasileira.

A hipótese de que a Biblioteconomia brasileira passou por um processo de institucionalização que consistiu ao mesmo tempo em rompimento, construção e afirmação identitária, torna-se central para esta tese. Rompimento este com o modelo exclusivo de biblioteca de preservação cultural, representada pela Biblioteca Nacional, e busca de construção de novas práticas, a partir de orientações bibliotecárias das public libraries (modelo anglófono) e da bibliothèque de lecture publique (modelo francês). Ou seja, a originalidade do "plano bibliotecário" modernista, consistiu em espécie de iniciativa cultural antropofágica, nos termos definidos por Oswald de Andrade, e que consistia em recriar em termos nacionais o que havia de melhor no mundo. Segundo Moraes (1942, p. 201), "nada nos imped[ia], em matéria de biblioteconomia, de nos aproveitarmos da experiência dos países mais adiantados". Nesse sentido, a identidade como pertencimento na construção coletiva de um "minimundo", conectado em sua totalidade com o todo (BAUMAN, 1999), não acontece naturalmente; ao contrário exige uma postura político-cultural, seja diante do passado colonialista, seja das novas formas que o colonialismo tomará, no Brasil republicano, sobretudo a partir dos anos 1930.

O projeto modernista brasileiro estava envolvido na busca de redefinição identitária por variados caminhos, dentre eles o da afirmação das raízes, da suposta memória cultural fundante do país. Nesses termos, não se tratava, simplesmente, de construção de bibliotecas ou da ampliação do número de "usuários". Tratava-se, antes, da unificação da nação em torno de sua memória cultural. Se, de um lado, o processo crescente de criação de bibliotecas e de institucionalização da Biblioteconomia possibilitou a criação de um espaço, ainda que restrito de práticas e de reflexões sobre tais questões, de outro, veio acompanhado de crises identitárias 
da biblioteca e de bibliotecários, dificuldade que se perpetua até hoje e pode ser identificada em discursos de variadas teorias sobre a função social e educativa da biblioteca.

Paradoxalmente, esse estado de crise constituiria a identidade da Biblioteconomia brasileira em diferentes tempos históricos? Tal crise seria exclusiva do campo? Estaríamos vivendo ainda um período juvenil, de um fenômeno que não conseguiu se afirmar no país, que busca seu lugar, em meio às avalanches informacionais e tecnológicas de nosso novo tempo?

Voltar aos momentos iniciais e significativos da formação da Biblioteconomia no país é, portanto, questão de ordem histórica fundamental para responder a dúvidas do presente; é atitude que poderá levar à definição segura e necessária do papel educacional e cultural das bibliotecas, em suas diferentes modalidades, na sociedade brasileira passada e presente, bem como nos rumos tomados pelo campo nas configurações sociais e científicas do presente.

No que diz respeito ao desempenho do ator social norteador deste estudo, Rubens Borba de Moraes, utilizaremos a noção de protagonismo cultural de Perrotti (2017), haja vista que a paixão de Moraes pelos livros (bibliofilia), aliada às condições sociais em que situava, levou-o da dimensão privada para uma dimensão pública (Bibliografia e Biblioteconomia). Para o autor, protagonismo cultural é uma "ação de embate com e pelos signos, tendo em vista a criação e recriação de significações que dão sustentação ao “viver junto'” (PERROTTI, 2017, p. 11). No que diz respeito ao ator desta ação temos um protagonista cultural que articula o seu modo de ser na ação (ARENDT, 2007), o que segundo Perrotti (2017, p. 17), implica "julgamento, linguagem, escolhas, decisões, opções”.

Tomando a ideia do protagonista como um lutador empenhado em participar do "jogo sociocultural de negociação simbólica” (PERROTTI, 2016, p. 15) é possível recorrer a Butlen (2008), que abordou a profissionalização de bibliotecários, na França, como um processo de passagem do bibliotecário militante para o bibliotecário profissional, vinculado à preocupação de resolver um problema social por meio das políticas públicas. A partir de leituras da sociologia e da ciência política, o autor apresenta o tratamento dado no "hexágono" a problemas ligados ao livro, à leitura e às bibliotecas. Interessa-nos no trabalho a articulação construída pelo pesquisador para delinear a passagem do bibliotecário militante para o profissional, dentre as quais observamos na presente tese: a) identificação do problema; b) construção do problema social; c) reconhecimento da concorrência com outros atores que veem o problema sobre diferentes perspectivas; d) construção de uma agenda política de chamada para o debate público; e) transformação de um problema em objeto de intervenção; f) transformação do problema social em política administrativa. Os conceitos trazidos pelo pesquisador ajudam-nos 
a elaborar uma leitura sobre a constituição do campo da Biblioteconomia a partir de seus processos de formação, institucionalização, consolidação e universitarização. ${ }^{7}$

Em contraponto ao bibliotecário por profissão temos o bibliotecário como ocupação (POIRIER, 2001), o bibliotecário tradicional, e cuja referência incluía os copistas, eruditos e eclesiásticos do período em que os caminhos da Biblioteconomia não tinham se cruzado com os das técnicas e tecnologias altamente elaboradas, nem com a explosão documentária e informacional. Os ocupantes dos cargos de bibliotecários na visão tradicional, segundo o autor, eram eruditos, administradores ou missionários. Sua tarefa consistia em administrar o acervo, reproduzir os modos de aquisição, organização e manutenção do acervo. Sua preocupação estava centrada na ordem do sistema e da estrutura, assim como no atendimento de demandas indicadas por "como e quando". Para Poirier (2001) a aceitação do status quo das coisas o leva a ser um "bom soldado" que cumpre o que é para ser feito. Em contraponto a este perfil, veremos nesta tese o bibliotecário líder, que é aquele que tem um envolvimento significativo e reflexivo sobre o fazer e o ser bibliotecário. Em vez de apenas administrar a instituição, ele se coloca como criador e não apenas reprodutor dos modos de fazer e ser. Para ele, as pessoas são a parte mais importante da instituição, ou seja, o leitor toma a centralidade antes ocupada pelo acervo. No caso do modernista Rubens Borba de Moraes, tal centralidade está na relação com os objetos culturais, ao que representam. Daí, talvez, a originalidade que imprimirá às suas ações que, de algum modo, colocam em articulação duas lógicas: a da conservação e a da difusão cultural.

A respeito da história da Biblioteconomia no Brasil, temos como referencial para esta pesquisa trabalhos que destacaram aspectos relacionados a modificações nos cursos de formação em Biblioteconomia do início do século XX, como, por exemplo, os de Castro (2000), Lima (1999) Laura Russo (1966), e Souza (1990; 1991; 1994; 2003; 2006; 2009).

O trabalho de Laura Russo (1966), editado pelo Instituto Nacional do Livro, na Coleção B2, tornou-se uma referência para os estudos históricos sobre o campo por apresentar uma cronologia detalhada e informativa, associada ao conjunto de leis que organizaram o campo da Biblioteconomia no país. Laura Russo usa a expressão uma "biblioteconomia nova", ao se referir ao crescente número de cursos de formação de profissionais para atuar na área. $\mathrm{O}$

\footnotetext{
${ }^{7}$ Considerando importante a afirmação do campo da Biblioteconomia a partir desta vertente, elegemos como objeto de investigação desta tese a formação da Biblioteconomia que, conforme demonstraremos nos próximos capítulos, se institucionalizou como campo político-cultural empenhado.
} 
presente trabalho dialoga com o livro de Laura Russo na tentativa de compreender os sentidos desta biblioteconomia "nova", entendida por Rubens Borba de Moraes na Divisão de Bibliotecas.

Lima (1999) apresenta um quadro crítico sobre a construção das dimensões políticopedagógicas do fazer bibliotecário. O autor desenvolve ao longo do livro a tese de que a Biblioteconomia brasileira não se consolidou como um campo social. Uma das justificativas para sua tese é que os problemas enfrentados na contemporaneidade pelo campo têm sua origem na formulação do primeiro curso de Biblioteconomia, oferecido pela Prefeitura de São Paulo. Para ele, a falta de uma liderança política (incluindo os professores do curso) e um projeto acadêmico mais amplo são alguns dos fatores que levaram à

[...] incapacidade para realizar leituras contextualizadas, fato que favoreceu o surgimento de práticas pretensamente neutras que insistiam em enxergar a dimensão técnica da profissão desvinculada das dimensões social e política e, por extensão, dos contextos do curso, represando a criação e limitando a expansão do modelo-Brasil de Biblioteconomia. (LIMA, 1999, p. 57)

Uma das justificativas do autor é de que talvez tenha faltado "convicção sobre as potencialidades da dimensão sociocultural da profisssão" (LIMA, 1999, p. 69). Em concordância com o autor sobre a importância de lideranças acadêmicas políticas no campo, e provocados pela ideia de que o projeto inicial de Biblioteconomia se rendeu cegamente ao tecnicismo estéril norte-americano, buscamos neste trabalho demonstrar o ideário político-cultural inscrito no plano bibliotecário dirigido por Rubens Borba de Moraes na Divisão de Bibliotecas e suas contradições, especialmente em país como o Brasil, marcado por graves problemas de escolarização, de formação e de participação na vida sociocultural. Os estudos de Souza (1990, 1991, 1994, 2003, 2006, 2009) dedicam-se à discussão de aspectos políticos e econômicos do país no período em que os cursos de Biblioteconomia estavam sendo implantados no Departamento de Cultura em São Paulo. Para Souza (1994), a ênfase tecnicista do campo se deve à importação do modelo norte-americano de classificação e catalogação; iniciativa atribuída à primeira Escola de Biblioteconomia do Brasil, organizado pela Divisão de Bibliotecas. Dado que o presente trabalho se centrou na análise interna ao campo, cobrindo-o no período de oferta do curso mencionado pelo autor, associaremos os estudos de Souza sobre a contextualização educacional e econômica nacional à investigação interna ao curso de Biblioteconomia da Divisão de Bibliotecas.

Souza (2009) provoca uma inquietação ao afirmar que o bibliotecário não tem cumprido seu compromisso social por viver sob o estigma da identidade desprestigiada pelo preconceito 
social de sua profissão, por sua vez alimentado por ele próprio, e que estaria associada ao "analfabetismo do zelador de documentos [...] como condição para guardar os tesouros do saber ou como atividade para não brancos" (SOUZA, 2009, p. 29). Com esta argumentação o autor nos aponta que o bibliotecário desconheceria o seu papel histórico-social, posição que nos inquieta a descortinar o "plano bibliotecário" da Divisão de Bibliotecas a fim de identificar quais as noções de biblioteca, Biblioteconomia e bibliotecário estavam presentes no momento de institucionalização da Biblioteconomia no país. Talvez fosse importante e necessário matizar a colocação e perguntar quais bibliotecários - e qual Biblioteconomia - desconheceriam o relevante papel histórico e social a que o autor se refere?

O trabalho de Castro (2000) buscou analisar os discursos construídos no campo entre os anos de 1950 e 1960 na literatura dessa época. A contribuição do autor está no fato de que ele apresentou a historiografia do campo pela organização e oferta de cursos de formação de bibliotecários. Castro (2000) nos apontou os anos 1960 como o auge das preocupações com a formação que se reveste de caráter tecnicista. Entretanto, dado o recorte da pesquisa, não foi possível avançar nas explicações do tecnicismo na formulação dos cursos oferecidos no país para além da atribuição decorrente da influência europeia ou norte-americana.

Sobre a atuação da Divisão de Bibliotecas, no campo da cultura, destacamos os trabalhos de Abdanur (1992), Assis (2013), Barbato Júnior (2004), Gomes (2008), Negrão (1979) e Raffaini (2001). O trabalho de Abdanur (1992) foi um dos primeiros a relacionar as ações do Departamento de Cultura a políticas culturais. A contribuição da autora está no fato de que discute a atuação dos modernistas, para ela ilustrados, como ato político de democratização cultural que provoca transformações no âmbito da cultura, lazer e ciência.

Também o artigo de Barbato Junior (2004) discute as ações desenvolvidas pelo Departamento de Cultura como políticas de democratização cultural. Enfatiza que as saídas em direção ao povo eram indícios de uma utopia nacional-popular. Seu trabalho ajuda-nos a contextualizar a Biblioteconomia dentro do projeto político-cultural desempenhada pelos modernistas. Especificamente sobre o aspecto da democratização da leitura, temos o trabalho de Gomes (2008) que, ao tratar do tema, fornece um arcabouço teórico sobre o sentido da biblioteca infantil num período de expansão da leitura no Brasil.

Já a pesquisa de Assis (2013) tem como objetivo apresentar, discutir e analisar a política cultural do Departamento de Cultura e Recreação da Prefeitura de São Paulo. Suas contribuições estão no fato de que ele discute as ações da Divisão de Bibliotecas como um "novo padrão de intervenção do Estado" no campo da cultura. Raffaini (2001) discute a atuação do grupo de modernistas sob o aspecto da identidade nacional e das transformações culturais 
que aconteciam na cidade. Traz contribuições no sentido de apresentar as ações do grupo como o embrião de um projeto nacional, em contraponto às políticas nacionais que vinham sendo realizadas por Getúlio Vargas. Negrão (1979) fornece dados factuais relacionados às mobilizações políticas internas à construção da Biblioteca pública Municipal, atual Biblioteca Mário de Andrade. Nesse sentido, trouxe contribuições para a construção da cronologia factual dos acontecimentos em torno da Biblioteca Pública Municipal de São Paulo.

Especificamente sobre a atuação de Rubens Borba de Moraes na Divisão de Bibliotecas, utilizamos o trabalho de Bandeira (2007), que construiu a biografia de Moraes, e o de Lima (2004), que realizou uma análise do discurso do mesmo. O trabalho de Bandeira (2007) vem corroborar com este estudo com apontamentos sobre a atuação de Moraes em torno do livro e das bibliotecas. No mesmo sentido, Lima (2004) desenvolve uma análise do discurso sobre o livro O problema das bibliotecas brasileiras, de Rubens Borba de Moraes (1943). Tal artigo apresenta interrogações sobre as marcas discursivas de Moraes que serão oportunamente aprofundadas na presente pesquisa.

\subsection{Objetivo}

Os objetivos apresentados a seguir são de duas naturezas.

\subsubsection{OBJETIVO GERAL}

Demonstrar que a formação do campo da Biblioteconomia no Brasil está associada a um projeto político cultural de construção de bases institucionais necessárias à afirmação da cultura letrada no país.

\subsubsection{OBJETIVOS ESPECÍFICOS}

- Identificar e analisar iniciativas, projetos e ações ligados saberes empíricos e epistemológicos das bibliotecas que corroboraram com a institucionalização da Biblioteconomia no país;

- Analisar a circulação de conceitos e experiências de biblioteca, bem como sua influência para a institucionalização da Biblioteconomia e da profissão de bibliotecário estabelecida no Brasil, no período; 
- Identificar e analisar o ideário político e cultural inscrito nas realizações articuladas por Rubens Borba de Moraes, bibliófilo, bibliógrafo e bibliotecário, participante ativo do grupo de idealizadores da Semana de Arte Moderna, de 1922, em São Paulo;

- Investigar as articulações conceituais sobre Biblioteca, Educação e Cultura mobilizadas nos projetos da Divisão de Bibliotecas do Departamento de Cultura e Recreação da Prefeitura de São Paulo, no que tange a ações de biblioteca, livro e leitura;

- Identificar as condicionantes fundadoras da Biblioteconomia Moderna no Brasil e que se relacionariam com as preocupações de modernização do país;

\subsection{Percurso metodológico 8}

O estudo foi desenvolvido a partir de pesquisa e análise documental, adotada a distinção de Oliveira (2007) que descreve como principal atividade da pesquisa documental "a busca de informações em documentos que não receberam nenhum tratamento científico, tais como relatórios, reportagens de jornais, revistas, cartas, filmes, gravações, fotografias, entre outras matérias de divulgação" (OLIVEIRA, 2007, p.69), ou seja, documentos primários que não foram analisados por pesquisadores de determinado campo científico.

Para Helder (2006, p. 1) a pesquisa documental é "uma das técnicas decisivas para a pesquisa em ciências sociais e humanas". É por meio desta metodologia de pesquisa que temos acesso a informações factuais que auxiliam a ordenar e elucidar criteriosamente problemas históricos. A escolha deste método de investigação requer do pesquisador um trabalho minucioso no que diz respeito à leitura dos documentos haja vista que os documentos não passaram por "tratamento científico" anteriormente (OLIVEIRA, 2007).

Sobre a análise dos documentos adotamos uma abordagem qualitativa oriunda da análise de conteúdo compreendida por Bauer e Gaskell (2002) como uma técnica de pesquisa que observa a materialidade linguística do texto. Esta metodologia prevê a leitura das condições

\footnotetext{
${ }^{8} \mathrm{O}$ acesso aos arquivos para a realização de estudo histórico-documental tornou-se um desafio para a concretização da pesquisa. Em países como o Brasil, onde questões da memória social não são tratadas com a devida atenção, e num momento de pandemia, ocasionada pela COVID-19, tal dificuldade se agiganta, podendo comprometer de forma irreversível buscas e resultados do trabalho. Um arquivo estratégico para nosso estudo, por exemplo, havia sido fechado por tempo indeterminado para consulta, devido à falta de profissionais. Depois de muitas tentativas, conseguimos acesso à parte do acervo, o que colocou a pesquisa em grande medida dependente da boa vontade de profissionais e da disponibilidade para atendimento a pesquisadores, ao mesmo tempo em que executam outras atividades na instituição. É preciso ressaltar que, em geral, contamos com a atenção dos funcionários, como colaboradores da investigação, o que ficou prejudicado com a pandemia. Infelizmente, é na dimensão pessoal e não institucional que as dificuldades da pesquisa nos arquivos são enfrentadas, não, portanto, no das políticas públicas de memória e de ciência.
} 
empíricas na construção do texto e permite ao analista transferir inferências do conteúdo para o contexto social.

Diante das características do desenvolvimento da Biblioteconomia brasileira com suas problemáticas identitárias, mencionadas anteriormente, entendemos que a área ressente-se de pesquisas apoiadas em fontes primárias, indispensáveis às suas definições e redefinições. Temos muito a desbravar sobre os meandros que ordenam a Biblioteconomia brasileira como campo de estudos e de práticas sociais e profissionais. Embora tenha crescido nos últimos anos o número de pesquisadores que revolvem arquivos, a fim de compreender o campo $^{9}$, ainda carecemos de matéria capaz de dar forma e consistência a um corpo de estudos situados além das funcionalidades e do imediatismo. Nesse sentido, depois de realizar o levantamento bibliográfico e, a partir dele, lançar perguntas que norteariam a pesquisa documental, partimos para as buscas nos arquivos, o que ocorreu em diferentes momentos, motivados pela necessidade de confirmação de informações e possibilidade de agregar novas pistas ao estudo.

Para esta pesquisa debruçamo-nos em acervos de diferentes arquivos e instituições, em busca de pistas sobre o processo de institucionalização da Biblioteconomia brasileira no período de 1935 a 1948, momento em que Rubens Borba de Moraes ingressou e atuou no campo da Biblioteconomia, ora em um projeto no município de São Paulo, na Divisão de Bibliotecas do Departamento de Cultura, ora na Biblioteca Nacional, período anterior, portanto, à sua saída do país, para atuar em organismos internacionais como bibliotecário.

\subsubsection{CORPUS DOCUMENTAL: LEVANTAMENTO}

O corpus documental desta tese, conforme será detalhado mais adiante, é composto por diferentes tipos de documentos. Como fonte privilegiada da atuação de RBM, identificamos documentos em forma de conferências, relatórios e dossiês. Além desses, foram objeto de investigação atos e correspondências oficiais e pessoais, envolvendo especialmente a figura de Rubens Borba de Moraes e seus principais parceiros e interlocutores no campo

\footnotetext{
${ }^{9}$ Conforme já dissemos, RBM é reconhecido internacionalmente como bibliotecário precursor da Biblioteconomia brasileira; no entanto, no Brasil, seu reconhecimento deve-se mais a suas condições de bibliófilo e bibliógrafo notável. Nos últimos anos, no entanto, cartas, diários de memórias e entrevistas concedidas por RBM receberam notoriedade com as publicações encabeçadas pelo professor Briquet de Lemos e pela Editora BBM, sob coordenação do professor Plínio Martins Filho, o que suscitou a necessidade de estudar com maior profundidade sua atuação como bibliotecário e formador de bibliotecários, além de protagonista destacado do processo constitutivo da Biblioteconomia no Brasil.
} 
biblioteconômico; publicações gerais e especializadas por ele realizadas; referências a suas iniciativas por parte de membros pertencentes a seu círculo de atuação; notícias de imprensa; registros de sua passagem por bibliotecas, acervos por ele constituídos, dentre outros materiais.

Logo no início da pesquisa, realizamos um levantamento documental no Instituto de Estudos Brasileiros, instituição que guarda uma parte considerável dos documentos oficiais do Departamento de Cultura. Paralelamente, fizemos buscas na plataforma digital do Centro de Pesquisa e Documentação da Fundação Getúlio Vargas e na Hemeroteca Digital, da Biblioteca Nacional ${ }^{10}$. Após o reconhecimento do corpus documental levantado, mapeamos instituições e pessoas que preservam documentos ligados aos interesses da pesquisa e construímos uma estratégia de busca nos arquivos físicos.

Ao longo das pesquisas, tanto em meios digitais quanto físicos, percebemos a necessidade de padronizar os procedimentos de levantamento e registro documental conforme as regras, organizações e formatações dos acervos consultados. Como termos de busca para as plataformas digitais, utilizamos inicialmente "biblioteconomia", "biblioteca", "departamento de cultura" e "Rubens Borba de Moraes". Após identificar os interlocutores de RBM, nos apropriamos de novas palavras-chave como, por exemplo, "biblioteca popular", "biblioteca infantil", além dos nomes de seus interlocutores ${ }^{11}$. Os documentos oriundos de arquivos físicos foram registrados fotograficamente e posteriormente selecionados. Já para os artigos de jornais disponíveis na Hemeroteca e Acervo Digital da Biblioteca Nacional, ao mesmo tempo em que tivemos acesso a eles, fizemos o processo de descrição em uma planilha criada para esse fim.

Além disso, realizamos entrevistas com remanescentes que lecionaram com Moraes, como o professor e bibliotecário Antonio Agenor Briquet de Lemos e com ex-alunos, como Suelena Bandeira, escolhida por ter realizado um estudo biográfico de Moraes.

Incluiu-se na lista de entrevistados, Aracy Abreu Amaral, correspondente de Moraes, desde os anos 60 até o final de seus dias, e Geraldo Faccó Vidigal, genro de Fernanda Guedes Galvão, filha de Fernando Guedes Galvão - a quem Moraes chamava de "minha família adotiva". As entrevistas forneceram informações sobre o legado de Moraes, bem como pistas dos registros de sua atuação. Foram investigados materiais referentes aos trabalhos de Rubens

\footnotetext{
${ }^{10} \mathrm{~A}$ "Biblioteca Nacional Digital Brasil" (http://bndigital.bn.gov.br/acervodigital/) é uma plataforma disponibilizada pela Biblioteca Nacional que indexa parte de seu acervo documental em formato digital para acesso aberto.

${ }^{11} \mathrm{Em}$ alguns arquivos, somente foi possível realizar as buscas manualmente no acervo físico, ou porque a recuperação documental demonstrava que a indexação era simplificada a ponto de ser inefíciente, ou porque a instituição não possuía instrumentos de busca; ou ainda por não ter nenhum sistema de automatização naquele acervo.
} 
Borba de Moraes na ALA, bem como consultados o Arquivo Central do Sistema de Arquivos da UNICAMP, a Academia Brasileira de Letras (ABL), e a Academia Paulista de Letras (APL), instituição onde ocupou a cadeira de n. 4 no ano de $1982^{12}$. As pesquisas incluíram, também, o Arquivo Municipal de São Paulo, o arquivo histórico da Biblioteca da Universidade de Brasília, o Cedoc da FESPSP, o Arquivo histórico do Instituto Mackenzie, Instituto Hércule Florence, Arquivo Público Mineiro, Biblioteca Monteiro Lobato, Centro de Memória da Unicamp (CMU), Centro de Documentação Cultural Alexandre Eulálio, e o Arquivo Edgard Leuenroth; estes três últimos lotados na Unicamp.

Como fontes importantes sobre a bibliofilia de Moraes, encontramos pistas inscritas nas notas de rodapé dos livros de sua biblioteca ${ }^{13}$, nos recibos de compra de livros, nas cartas trocadas com seus interlocutores ${ }^{14}$, nas publicações sobre bibliofilia, em seus textos memorialísticos, assim como em textos publicados por insiders ${ }^{15}$ e nas cartas trocadas com um livreiro português, António Tavares de Carvalho, recém-publicadas em formato de livro, por Plinio Martins Filho ${ }^{16}$. Outra obra é $O$ bibliófilo aprendiz: prosa de um velho colecionador para ser lida por quem gosta de livros, mas pode também servir para quem deseja formar uma coleção de obras raras antigas ou modernas, cuja primeira edição, no ano de 1965, foi publicada pelo próprio Moraes. Sobre a paixão de RBM pelos os livros, a referência é seu livro de memórias publicado postumamente por Briquet de Lemos ${ }^{17}$ e cujo título é Testemunha ocular: recordações. O que sabemos sobre a vida particular de RBM é resultado dos estudos de materiais relacionados à sua bibliofilia e de entrevistas com pessoas que conviveram com ele.

A face de RBM como bibliógrafo está registrada em cadernos de anotações pessoais, bem como em correspondências trocadas por ocasião das publicações de obras como o Manual bibliográfico de estudos brasileiros, publicado em 1949, sob a direção de Rubens Borba de Moraes e William Berrien, e a Bibliographia Brasiliana (2010) ${ }^{18}$, que segundo (DEAECTO,

\footnotetext{
${ }^{12} \mathrm{RBM}$ foi eleito para a cadeira $\mathrm{n}^{\circ} 4$ da Academia Paulista de Letras em 30/10/1980, no entanto, só tomou posse em 30/06/1982.

${ }^{13}$ Cf.: ANTUNES, C. Rubens Borba de Moraes: anotações de um bibliófilo. São Paulo: Publicações BBM, 2017. ${ }^{14}$ No caso, considerava interlocutores: Mário de Andrade, José Mindlin, Sérgio Buarque de Holanda, livreiros brasileiros e estrangeiros.

${ }^{15}$ Utilizamos neste texto a ideia de Schutz (1962), para quem insider pode tratar-se de pessoas enraizadas no contexto da bibliofilia; nesse caso consideramos outros bibliófilos, que, segundo Bourdieu, estão inseridos na lógica do campo constituído.

${ }^{16}$ Cf:: MARTINS FILHO, P. (org.). Cartas de Rubens de Moraes ao livreiro português António Tavares de Carvalho. São Paulo: Biblioteca Brasiliana Guita e José Mindlin, 2018.

${ }^{17}$ Cf.: MORAES, R. B. de. Testemunha ocular: recordações. Brasília: Briquet de Lemos, 2011.

${ }^{18}$ Obra publicada originalmente em 1958, em inglês, sob o título: Bibliographia Brasiliana: rare books about Brazil published from 1504 to 1900 and works by Brazilian authors of the Colonial period. Em 1958, Moraes publica uma segunda edição ampliada da obra pela Editora Kosmos e pela UCLA (Latin American Center
} 
2011) impulsionou a fixação de uma ideia que partia de um conceito de coleção bibliográfica e avançava no sentido de provocar reflexões sobre o lugar do livro e da memória cultural na história nacional.

Embora não seja objeto de estudo desta tese, consideramos também a entrada de RBM em terrenos de difusão cultural, quando ingressou no universo da editoração, assunto que pode ser encontrado em publicações das revistas Klaxon (1922) e Terra Roxa e Outras Terras (1926).

Para perceber a visão de RBM sobre Biblioteconomias vigentes no mundo, buscamos as referências utilizadas para embasar os dois cursos que lecionou na Escola de Biblioteconomia, as transcrições das aulas dos cursos, as atas de reuniões das quais participou junto às comissões internacionais de Biblioteconomia e discursos proferidos sobre biblioteca e Biblioteconomia.

\subsubsection{CORPUS DOCUMENTAL: TRATAMENTO, SELEÇÃO E ANÁLISE}

Ao longo do estudo, fomos aprimorando os critérios de seleção e métodos de tratamento dos documentos. No que diz respeito ao registro do tratamento dado aos documentos, construímos algumas ferramentas utilizando recursos da Microsoft. O principal deles foi um arquivo em Excel, intitulado "Corpus Documental", com duas planilhas, uma para os documentos manuscritos e datilografados (Documentos gerais) e outra para os artigos de jornais (Artigos). Os campos dos "Documentos gerais" são: tipo documental, data, autoria, local, assunto, descrição, acervo, código (número de identificação do documento no acervo), nome (nome do arquivo na pasta do pesquisador), quantidade de páginas, link/endereço e observação. Para a aba dos artigos de jornal, estabelecemos os seguintes campos: tipo documental, periódico, data, local, palavras-chave, nome do arquivo, página, assunto, observação, link e número da ocorrência. As informações geradas a partir dos registros nestas tabelas foram utilizadas para alimentar o arquivo intitulado "Cronologia Geral", e outro, nomeado como "Mapa de caligrafias". O arquivo "Cronologia Geral" permitiu-nos organizar as pistas de forma cronológica, relacionando acontecimentos relatados na bibliografia sobre Biblioteconomia, com pistas encontradas nos documentos. Já o "Mapa de Caligrafias" foi construído por necessidade de um instrumento que ajudasse no reconhecimento das caligrafias de documentos manuscritos e de assinaturas em documentos datilografados.

Publications). Em 2010, a Edusp edita a primeira versão em português - MORAES, Rubens Borba de. Bibliographia brasiliana: livros raros sobre o Brasil publicados desde 1504 até 1900 e obras de autores brasileiros do período colonial. São Paulo: Edusp, 2010. 
Diante do conjunto de documentos recuperados, indicamos os motivos da reunião, para que alguns tipos de registros fossem privilegiados na presente pesquisa: a) os textos memorialísticos apresentaram a voz de Rubens Borba de Moraes como narrador e, devido ao seu modo de produção, traduziram a dinamicidade constitutiva de Moraes como sujeito que se autodescreve e ao mesmo tempo narra as dinâmicas de que é testemunha; b) conferências proferidas por Moraes dentro e fora do país permitiram observar o posicionamento dele nos debates sobre biblioteca e Biblioteconomia no período estudado; c) os artigos de jornal agregaram elementos factuais e discursivos na análise da repercussão dos trabalhos da Divisão de Bibliotecas; d) os documentos oficiais ligados às ações de Moraes, na Divisão de Bibliotecas e na Biblioteca Nacional, constituem parte da memória social da Biblioteconomia concretizada no período estudado.

A leitura de textos memorialísticos foi crucial para entendermos a construção da “identidade de Moraes”, inscrita na organização de seus arquivos pessoais e também em discursos, incluindo suas aulas e as palestras de 1943 e 1947, analisadas na presente tese. Nesse sentido, lemos a escrita autorreferencial de RBM como tentativa de construir sua identidade e memória, conforme apontado por Gomes (2004).

O mergulho na análise dos documentos selecionados sobre Rubens Borba de Moraes trouxe à tona um traço de personalidade que desafia o pesquisador, já que Moraes demonstra ter sido bastante obcecado pela memória que deixaria. É notável como ele projeta sua imagem de acordo com o seu interlocutor. Disso resulta que algumas vezes ele recria informações diferentes das apresentadas nos documentos de seu arquivo. Os silêncios também merecem destaque, pois Moraes deixa escapar algumas pistas sobre as disputas internas do campo.

Nesse sentido, observamos o que Gomes (2004) diz sobre a escrita autorreferencial, como modo do indivíduo moderno construir seus arquivos.

O ponto central a ser retido é que, através desses tipos de práticas culturais, o
indivíduo moderno está constituindo uma identidade para si através de seus
documentos, cujo sentido passa a ser alargado. Embora o ato de escrever sobre
a própria vida e a vida de outros, bem como de escrever cartas, seja praticado
há muito, seu significado ganha contornos específicos com a constituição do
individualismo moderno. A chave, portanto, para o entendimento dessas
práticas culturais é a emergência histórica desse indivíduo nas sociedades
ocidentais (GOMES, 2004, p. 11).

Por longo tempo, o gênero das memórias consistiu em uma parte desprezada da crítica literária, como se a subjetivação a que se refere Gomes (2004) no trecho acima comprometesse a seriedade do texto. A individualidade expressa através do romance consistiria em um texto 
denso, em que os caracteres autobiográficos emergissem refratados pelas escolhas estéticas e narrativas do autor. A mesma individualidade expressa através das autobiografias, ao contrário, se reduziria a narrativas superficiais e esquemáticas daquilo que a individualidade quer dar a conhecer de si mesmo, retirando do leitor a visão sobre outros aspectos.

Desde a década de 1970, a crítica literária francesa enxerga a autobiografia de maneira mais complexa: como um pacto (LEJEUNE, 2008) entre o autor/narrador/personagemprincipal e o leitor, chamados a participar da narrativa em sua condição de alguém que pode reavaliar, extrapolar as afirmações escolhidas para compor a memória. No caso de Rubens Borba de Moraes, as memórias foram sendo publicadas por meio de entrevistas e, já na primeira década do século XXI, o último texto que havia permanecido inédito veio a lume, e segundo Briquet de Lemos na apresentação do livro, elas continham anotações indicativas de que Moraes considerava o texto pronto para publicação.

Desse modo, trataremos dos textos autobiográficos de Rubens Borba de Moraes como carregados da intencionalidade de se dar a conhecer ao leitor, a partir de um processo histórico de acumulação das lembranças, dos sentidos atribuídos a elas e da mobilização que se esperava alcançar nos interlocutores (no caso das entrevistas) e dos leitores (incluindo-se aí o livro “Testemunha ocular"). Com isso pretendemos chamar a atenção do leitor para o fato de que trataremos as informações trazidas pelo livro sob múltiplos prismas: há dados factuais relevantes para nossa pesquisa, mas há também interpretações, aporias, jogos de retóricas com estes dados que precisam ser levados em conta na interpretação da escrita.

Outro manancial de vozes do passado consultado foi a grande imprensa da cidade de São Paulo durante a década de 1930. Trabalhar com periódicos de grande circulação impõe uma série de protocolos teóricos. Periódicos possuem linhas editoriais mais ou menos definidas e coerentes, que podem mudar com o tempo. Apresentam variações de público expressas pela importância e organização dos temas no mesmo exemplar, perceptíveis pela forma como o espaço das páginas está dividido. O que aparece com maior destaque como manchete do jornal? Qual o espaço conferido para as associações e as manifestações culturais?

A resposta a estas perguntas e observações exige que o periódico seja acompanhado para muito além do pequeno espaço no qual a notícia/artigo de interesse direto foi publicada. É preciso localizá-la no conjunto de cadernos do periódico, é preciso relacioná-la com alguma possível afiliação política - no caso de São Paulo, é muito evidente a ligação dos jornais com os partidos políticos - e reconhecer a marca destas condicionantes no texto final. 
O amplo leque de documentação consultada para a redação da tese permitiu a organização de um texto multifacetado, composto por questões que se entrecruzam e se complementam. Por este motivo, estruturamos a tese da forma exposta abaixo.

\subsection{Estrutura da tese}

Na primeira parte do texto, passaremos pela biografia de Moraes com o objetivo de elucidar, para os próximos capítulos, aspectos ligados à sua formação cultural e trajetória intelectual, que o levaram a ser considerado como uma figura emblemática da Biblioteconomia (Moderna) Brasileira. Compreender a formação do habitus, especialmente durante o período entre os 11 e os 20 anos, vividos em Genebra, tornam inteligíveis as opções vistas em meados da década de $1930^{19}$.

Depois de apresentar aspectos da vida pessoal de RBM, iniciamos o segundo capítulo com o contexto encontrado por RBM no seu retorno, em 1919, e processo de adaptação à cultura brasileira, após sua formação na Suíça. Tomamos a trajetória profissional de RBM em sua passagem pela Divisão de Bibliotecas do Departamento de Cultura (1935-1942) para compreender o papel exercido por ele e outros atores de políticas públicas na cidade de São Paulo ligadas à cultura, ou seja, às bibliotecas e ao conjunto de ações que estão na origem da criação do campo no país.

No terceiro capítulo, tratamos da atividade de RBM na Escola de Biblioteconomia, tanto na condição de docente como de diretor. Interessa-nos observar as concepções de Biblioteconomia e de bibliotecário mobilizadas concretamente por ele. Anunciava-se, ali, uma Biblioteconomia diretamente articulada com dinâmicas políticas, sociais, educacionais e culturais do país e que via na superação da dicotomia entre técnica e erudição um indispensável meio de realização de objetivos de superação das barreiras históricas de acesso à cultura letrada, enunciação de questões que seriam retomadas nas políticas culturais de outros países na categoria de "democratização cultural" e, atualmente, de "democracia cultural".

No quarto capítulo, enxergamos um RBM em transição. Ele e seus estudantes participam dos movimentos profissionais articulados mobilizados para a criação de bibliotecas e regulação do mercado de trabalho de bibliotecários. Quando a Escola de Biblioteconomia,

\footnotetext{
${ }^{19}$ Não se trata de incorrer na "ilusão biográfica" descrita por Bourdieu (ILUSÃO, 2017) como a ingenuidade de ler a trajetória social de um indivíduo como uma progressão linear de acúmulo de propriedades sociais, como se a fase adulta fosse o desenvolvimento em ato do que potencialmente já estaria inscrito na sua infância. Como se verá melhor no primeiro capítulo, a questão aqui é o papel vicariante que a escola e a residência genebrina tiveram na ausência da instituição familiar, geralmente reprodutora do habitus no processo de socialização dos indivíduos.
} 
idealizada por RBM, perde a subvenção da Prefeitura de São Paulo, debates e disputas políticas, epistêmicas e profissionais a respeito da formação de bibliotecários e do que se entende por Biblioteconomia, tomam forma de processo administrativo, conferências, relatórios e artigos de jornal; lógica paradoxal que diferencia e ao mesmo tempo relaciona organicamente diferentes concepções de biblioteconomia que se desdobraram em cursos de Biblioteconomia pelo país.

Ainda neste capítulo, vislumbraremos as desventuras que o conduzem a uma passagem bastante atribulada pela administração federal, no Rio de Janeiro. Buscamos demonstrar como a literatura sobre a história da Biblioteconomia tem sido reducionista na leitura deste episódio, posicionando-o como uma espécie de "mito fundador" às avessas da Biblioteconomia, como o início de nossos problemas, na adoção de um tecnicismo estéril para os objetivos da classe profissional em contribuir para a superação do fosso a separar as frações sociais e seu acesso à produção cultural.

Ao final, já nas considerações finais, retomamos algumas ponderações dos capítulos anteriores (2-5), em relação aos desdobramentos do "plano bibliotecário" que se ocupou da articulação de conhecimentos de diferentes matrizes com vistas a construir, no Brasil, uma "Biblioteconomia modernista" empenhada em colocar a "memória em ação". 


\section{UMA BIBLIOTECONOMIA EMPENHADA ${ }^{20}$}

A Biblioteconomia emergiu, no Brasil, como $\operatorname{campo}^{21}$ socioprofissional e epistêmico, no transcorrer do século XX, ligada inicialmente a um ideal político e cultural empenhado na construção e afirmação de uma nação livre, independente e "moderna", capaz de superar marcas vivas do atraso herdadas, sobretudo de sua condição colonial (BOSI, 1992).

Já no alvorecer da República, nota-se uma constelação de esforços no sentido de criação de instituições que dessem objetividade e condições de desenvolvimento à cultura letrada entre nós, que levariam ao surgimento de novo campo diretamente associado ao projeto de modernização política, social e cultural que nos livraria da dependência, da subserviência e da ignorância impostas pelas amarras do colonialismo.

Conforme demonstrado por Saviani (2013) e Nagle (1976), nos anos iniciais da República persiste um otimismo na imprensa de que os problemas nacionais seriam resolvidos pela cultura republicana de investir na escolarização inicial de toda a população. Reformas educacionais como a de 1891, no Estado de São Paulo, apontariam a direção a ser seguida por todas as unidades da federação, no sentido de ampliar a rede pública e abarcar mesmo os rincões mais afastados dos grandes centros. Deste modo, acreditava-se, o Brasil seria salvo de sua própria ignorância.

Se por um lado os vícios da administração pública e da cultura política da Primeira República demonstraram a ingenuidade deste raciocínio, por outro lado a preocupação com a educação lançou interpretações que seriam retomadas nas décadas seguintes. Para alguns destes herdeiros, como os modernistas Mário de Andrade e Rubens Borba de Morais, o livro e a educação permaneceriam sendo centrais para as discussões sobre o que deveria ser o Brasil, sob as novas perspectivas.

\footnotetext{
${ }^{20}$ O termo "empenhada" é tomado no sentido utilizado por A. Candido, em sua obra Formação da Literatura Brasileira (momentos decisivos) no qual descreve: “Os escritores neoclássicos são quase todos animados do desejo de construir uma literatura como prova de que os brasileiros eram tão capazes quanto os europeus: mesmo quando procuram exprimir uma realidade puramente individual, segundo os moldes universalistas do momento, estão visando este aspecto (...) Depois da Independência, o pendor se acentuou, levando a considerar a atividade literária como parte do esforço de construção do país livre, em cumprimento a um programa (...) 'à tomada de consciência' dos autores quanto ao seu papel, e à intenção mais ou menos declarada, de escrever para a sua terra, mesmo quando não a descreviam" (CANDIDO, 1969, p. 26).

${ }^{21}$ Empregamos a definição de campo proposta por Pierre Bourdieu em trechos como o que segue: "Compreender a gênese social de um campo e apreender aquilo que faz a necessidade específica da crença que o sustenta, do jogo de linguagem que nele se joga, das coisas materiais e simbólicas em jogo que nele se geram, é explicar, tornar necessário, subtrair ao absurdo do arbitrário e do não motivado os atos dos produtores e as obras por eles produzidas.” (BOURDIEU, 1992, p. 69, grifo nosso). Para uma discussão mais aprofundada do porquê usar "campo" e não outros conceitos hermenêuticos de leitura desse objetivo, consultar a Introdução da presente tese.
} 
Para eles, deveríamos deixar de olhar o livro - e tudo o que se relacionasse a biblio como objeto de memória cristalizada e focar em seu papel de mobilizador sociocultural do presente e do futuro. Uma teia bibliotecária, constituída não mais sob o critério prioritário da preservação, mas da circulação de ideias (PERROTTI, 2017) viabilizaria tal deslocamento, permitindo ao povo brasileiro acesso à educação e à cultura "modernas", condição de superação das forças arcaicas que teriam obstruído caminhar do país rumo a seu destino histórico, de grandezas homólogas às suas enormes grandezas naturais, cantadas em prosa e verso, desde a Carta de Caminha.

Segundo Rubens Borba de Moraes, figura emblemática dessa mobilização histórica que envolveu diferentes gerações ao longo do século XX, as bibliotecas eram entendidas, entre nós, como "hospitais de almas" 22 , totalmente apartados dos problemas nacionais. Necessitavam, portanto, ser redefinidas para assumirem a condição de agentes educativos que, mediante a disponibilização cultural para todos, reverteriam a desoladora posição de insignificância que o país ocupava no concerto internacional das nações.

Portanto, a Biblioteconomia emerge no país sob a bandeira de um Brasil inclusivo, supostamente para todos e pronto para realizar seu "destino histórico" 23 de país do futuro. As bibliotecas acolheriam e mobilizariam crianças, mulheres, operários, trabalhadores do campo ou das cidades, habitantes de bairros centrais ou das periferias, intelectuais e letrados de alta cultura, analfabetos desprovidos de escolaridade, mas indispensáveis ao projeto de afirmação nacional.

Tal como fez Candido (1969) com o processo de "formação" do campo da Literatura Brasileira e seus desdobramentos, tomar nessa perspectiva o da Biblioteconomia, categoria inexpugnável dos "sistemas" culturais letrados, é modo de contribuir para o entendimento e o enfrentamento de problemas educacionais e culturais que vêm e continuam marcando a vida brasileira, incluindo aí problemas que afetaram e afetam o próprio campo. Se este nasceu empenhado, no Brasil, como em várias outras partes, acabou cedendo múltiplos espaços à

\footnotetext{
${ }^{22}$ Moraes (1943) toma o sentido imaterial dos livros para lançar críticas ao mesmo tempo a duas concepções de biblioteca: a de conservação, vigente no Brasil no século XIX, e a biblioteca instrumento de doutrinação espiritual. Faz alusão a uma concepção reducionista de biblioteca, que a limita a ser parte do projeto sanitarista que visava orientar a população quanto à higiene pessoal.

${ }^{23}$ Subsistem na retórica dos grupos que apoiam a Biblioteconomia em seu surgimento, leituras distintas sobre o Brasil, mas que se encontram na defesa da ideia de que o Brasil possuiria um grande potencial para integrar o "concerto das nações civilizadas", sem que isso representasse aceitar o discurso racialista de crítica à mestiçagem e defesa do embranquecimento da população. O mestiço "prodigioso de energia física e de iniciativas" de Menotti del Picchia ou o Macunaíma "herói sem caráter" de Mário de Andrade são, mesmo que de maneiras distintas, portadores de um projeto de desenvolvimento cultural brasileiro que não deixaria margens para se pensar em inferioridade em relação a outros países. Sobre a relação entre literatura modernista, ciência eugenista e a questão racial, veja: cf. El-Dine $(2016,2019)$.
} 
funcionalização, ao pragmatismo, aos procedimentos técnico-operacionais, tomados à parte da ordem histórica e cultural que lhes deu origem e sentido. Por tais razões, geraram-se conflitos graves e insuperáveis, dualismos e disputas entre ordem técnica e ordem cultural, ordem documentária e ordem social, tratamento e apropriação de informação e cultura.

Buscar compreender, portanto, como se deu a formação do campo biblioteconômico no país é uma tarefa de importância fundamental, tanto sob a perspectiva científica do próprio campo, como cultural, em seu sentido amplo, já que a constituição de um campo é tanto a delimitação de um espaço singular, particular, como o estabelecimento de uma área relacionada a outras áreas interconectadas e em movimentos dinâmicos de aproximações e disputas.

Rubens Borba de Moraes, bibliófilo, bibliógrafo e bibliotecário, é figura emblemática e que marca fortemente esse momento de constituição da área da Biblioteconomia, no país, por ter protagonizado e encabeçado projetos e iniciativas que foram basilares à constituição do campo biblioteconômico, no Brasil. Nesse sentido, partimos do exame de sua "biografia social" 24 e sua relação com o contexto cultural da época, em especial, o da cultura escrita. Assim, após nos referirmos a seu período de estudos entre a infância e a juventude, passamos a abordar diferentes vertentes que marcam esse intelectual singular e controvertido que se confunde, reflete e refrata contradições próprias à formação do campo no país, estruturalmente vinculado em sua origem a um projeto político-cultural de nação e a tudo o que isso representará. Temos, pois, os seguintes desdobramentos no texto que se segue, após essas considerações sobre a formação na infância e juventude: "Uma comunidade de saberes"; "Ingresso no universo da difusão cultural"; "RBM, intelectual e político"; "O bibliotecário modernista: o conhecimento em ação" e "Da bibliofilia à ordem dos livros".

\subsection{Uma vida entre livros}

Rubens Borba de Moraes "teve uma vida entre livros"25. Nasceu em 23 de janeiro de 1899, natural de Araraquara, cidade do interior do Estado de São Paulo, em um período durante o qual o cultivo do café, iniciado em meados do século XIX, estava no auge de seu crescimento. Imigrantes de diferentes procedências, sobretudo europeus, chegavam ao Brasil nesse período,

\footnotetext{
${ }^{24}$ Entendemos por biografia social a trajetória de RBM como bibliófilo, bibliógrafo e bibliotecário. Apoiamo-nos na concepção de biografia descrita por Dosse $(2007,2009)$ como uma leitura histórica ligada à singularidade, à reflexão sobre as heterogeneidades de sujeitos que têm uma trajetória não linear. Uma característica desse tipo de leitura é a "variação do enfoque analítico, pela mudança constante da escala, que permite chegar a significados diferentes com respeito às figuras biografadas" (DOSSE, 2009, p. 195).

${ }^{25}$ A expressão "Uma vida entre livros" foi usada por Mindlin (1998b) no título de sua obra memorialística na qual relata a relação de amor que construiu com os livros ao longo de sua vida.
} 
para trabalhar em fazendas. Ao mesmo tempo, alguns deles direcionavam-se aos centros urbanos que se formavam, impulsionados pelos excedentes proporcionados pelo café, assim como por um esforço inicial de industrialização, entendida como sinônimo de progresso e civilização.

As cores da imigração, especialmente a italiana, são as tintas da primeira infância de Rubens Borba de Moraes, um indicativo de que sua reflexão sobre a identidade nacional surge de um desconforto com as visões canonizadas sobre o mundo rural brasileiro. Nas suas memórias, orgulha-se de pertencer a uma família pioneira no estímulo à imigração ${ }^{26} \mathrm{e}$ que, portanto, teria auxiliado a modernizar a paisagem rural da parte do Brasil onde nasceu, despertando-lhe certo estranhamento às marcas da condição colonial, visíveis em outras partes do país:

A minha geração que nasceu nas fazendas do Oeste paulista em princípios do século $[\mathrm{XX}]$ não viveu sua infância entre mucamas e mães pretas como os brasileiros do Norte com a mesma idade. Lembro-me dos comentários que fazíamos, meus amigos e eu, logo que apareceram Casa-grande \& Senzala, de Gilberto Freyre, os romances de José Lins do Rego, de Jorge Amado e toda essa literatura autobiográfica que se despejou bruscamente sobre o Brasil, depois de 1930. Era um mundo novo e desconhecido que se abria para nós. [...] Os livros que nos falavam ao coração, que sentíamos como coisa vivida, eram os de Antônio de Alcântara Machado, Juó Bananère e de Mário de Andrade. Mas esse São Paulo italiano de nossa infância, esse Brás, Bexiga e Barra Funda, desapareceu como está desaparecendo o engenho de José Lins do Rego e a Bahia de Jubiabá, tão poeticamente descrito por Jorge Amado. Não foram o getulismo e o salário mínimo, nem as revoluções que mudaram e estão mudando cada vez mais o Brasil. Foi o progresso técnico e a industrialização. (MORAES, 2011, p. 39, grifo nosso)

Com o retrabalho da memória que recolhe suas impressões da vida ao longo de três décadas (entre 1960 e 1980), RBM retorna ao que significou para ele ter o contato com a segunda geração de modernistas da literatura, o romance social, o modernismo regionalista de

\footnotetext{
${ }^{26}$ Ao mesmo tempo, em Testemunha ocular, Rubens Borba de Moraes faz algumas menções sobre sua convivência com os afrodescendentes, e para as quais apontamos como caminhos para pesquisas futuras. Por exemplo, quando dá a entender que sua família "libertou" os escravos por volta da década de 1880, sendo antes da abolição - período em que o Movimento Abolicionista já surtira efeito sobre a opinião pública e sobre a legislação, revertendo a duras penas um processo de conservação ad eternum das estruturas escravocratas nas relações de trabalho. Também notamos outras passagens nas quais, apesar de se dizer livre de preconceitos de raça, classe ou gênero, Rubens Borba de Moraes não vai além desses limites pessoais que desconsideram o racismo estrutural determinante na vida de qualquer brasileiro, inclusive na sua. Ao tratar de um dos "poucos negros da fazenda de minha avó", comenta: "Essa família também meu irmão herdou. Tomé morreu na [fazenda] São Luís. Os filhos e netos ainda estão por lá. Uma neta do Tomé de Souza foi criada, durante anos, de minha cunhada" (MORAES, 2011, p. 41). Este é apenas um exemplo entre outros possíveis para demonstrar que a reprodução das desigualdades sociais com base em características étnicas não provoca, em Moraes, nenhum comentário. Evidentemente, não se pode desconsiderar que a visão de mundo de RBM se formou na primeira metade do século XX, e que nós, brasileiros do século XXI, nos apoiamos no acúmulo de reflexões críticas durante e após o período de existência de Rubens Borba de Moraes.
} 
Gilberto Freyre - com quem Moraes estabeleceu sólida parceria entre os anos 1930 e $1940 .{ }^{27}$ Em ambos os casos, Moraes engrossa os traços do desenho em que contrasta o Estado de São Paulo com o restante do país nas primeiras décadas do século XX, mas também os aproxima no destino que o processo de modernização (a urbanização e a industrialização) lhes reservaria.

O trecho escolhido aborda vários pressupostos das pugnas de Rubens Borba de Moraes ao longo de sua biografia, bem como de lacunas que interferirão nos destinos de projetos por ele representados. Sua leitura sobre as diferenças entre a configuração social de São Paulo e a do restante do país, assim como a importância conferida às transformações advindas da modernização, são prenúncio de disputas e de posições que serão desenvolvidas ao longo da presente tese. Antes, porém, é preciso abordar sua infância e juventude.

Filho de Antonio Mariano Alves de Moraes e Alcídia Borba de Moraes, era, segundo ele próprio, descendente por parte materna do bandeirante Borba Gato. Seu pai era engenheiro chefe do serviço de engenharia do quartel-general da $9^{a}$ região militar. Sua mãe morreu em 1903, quatro anos após seu nascimento, quando passou a ficar sob os cuidados da avó e tias maternas, na fazenda Atalaia. Em 1906, foi morar com seu pai, engenheiro residente na cidade de Santos, onde trabalhava, mudando-se durante a infância para Curitiba, Paris e São Paulo, para acompanhar o pai em seu trabalho (MORAES, 2011).

Embora tenha convivido pouco com o pai, considerava-o "camaradão" e remetia suas lembranças aos livros por ele presenteados ou indicados (MORAES, 2011). Antonio Mariano Alves de Moraes fora aluno de Benjamim Constant no colégio da praia Vermelha, no Rio de Janeiro. Confiava na didática do mestre que, ao invés de decorar, preferia ensinar a raciocinar. Tal convicção justificaria seu ingresso tardio na educação formal, que segundo ele próprio, só conheceu a escola ao ingressar em um colégio interno aos dez anos de idade, em Paris.

A decisão de enviar filhos a estudar no exterior não era incomum entre os membros da elite nacional na Primeira República, não obstante o fortalecimento da preocupação com os destinos da educação nacional. A justificativa apresentada pela família para enviar Rubens era de que os custos da educação ginasial seriam muito elevados no país ${ }^{28}$ e seria mais barato e melhor enviá-lo à França, conforme ele próprio relata em sua biografia (MORAES, 2011), onde teria parentes para acolhê-lo.

\footnotetext{
${ }^{27}$ Para entender mais sobre essa parceria, consultar o capítulo 4 da presente tese.

${ }^{28} \mathrm{Com}$ a reforma da Instrução Pública de 1892, o ensino no Brasil foi organizado em três etapas: ensino primário, secundário e superior. $\mathrm{O}$ ensino primário era obrigatório e gratuito e deveria ser completado até os 12 anos de idade. O ensino secundário realizado nos ginásios tinha que ser custeado pelas famílias. Possivelmente Moraes refere-se à formação correspondente ao ensino secundário, o que coincide com o período em que é enviado para a Suíça, conforme veremos adiante.
} 
A preocupação com o custo pode ser justificada pelo monopólio das corporações católicas (p. ex. beneditinos, jesuítas e salesianos) no fornecimento do ensino na etapa de ginásio e secundário, salvo raras exceções de escolas públicas exemplares, geralmente alguns poucos grupos escolares por cidade. A mobilidade geográfica do pai de Rubens também pode ter pesado na escolha, assim como a sedução que a cultura francesa desempenhava; quando esteve em Paris pela primeira vez, acompanhado de seu pai, Rubens visitou "tudo quanto era museu" com ele e conheceu o teatro de Sarah Bernhardt.

Ainda criança, Moraes sai, portanto, de um mundo onde predominava ainda a linguagem oral e vai ser alfabetizado num país em que o domínio da linguagem escrita já era preocupação central dos sistemas de ensino, tanto como meio de expressão como de comunicação "modernos". Tal fato significa dizer que, enquanto a França vive em clima da Belle Époque, celebração da modernização, progresso cultural e técnico-científico, o Brasil, com seu passado colonial, está imerso num índice de analfabetismo que atinge no início do século XX $84 \%$ da sua população (SALIBA, 2010).

RBM não se demora em comentar esta passagem do oral ao escrito e que, ao que parece, não gerou grandes dificuldades de domínio cognitivo do sistema da escrita. Entretanto, o período no qual estudou na França não foi de fácil adaptação ao meio, com choques culturais que fizeram com que seu pai o retirasse da escola em 1910 e o trouxesse de volta a São Paulo (MORAES, 2011).

A estadia de Rubens Borba de Moraes pela capital paulista, entre 1910 e 1911, não é detalhado em seus textos memorialísticos. Sabemos deste fato porque Moraes foi matriculado no Colégio Macedo de Soares, frequentado pela elite cultural e econômica local. É desse período que remontam suas recordações mais antigas da família de Mário de Andrade (18931929), com a qual se relacionou, antes do ingresso no Colégio de Genebra, na Suíça, para onde foi levado, em 1911 (MORAES, 1979).

Vale ressaltar que tanto a família de Rubens Borba de Moraes quanto a de Mário tinham meios que lhes permitiam acessar equipamentos culturais. Um dos indícios disso é que, juntamente com Renato Andrade (1899-1913), irmão de Mário, frequentou a primeira sala cinematográfica de São Paulo, a Bijou-Theatre, inaugurada na Rua São João, em $1907^{29}$, quando tinha apenas oito anos. Tal condição nos permite destacar aspectos de habitus $^{30}$ da

\footnotetext{
${ }^{29}$ Carta recebida de Renato, irmão de Mário de Andrade, por RBM, datada de 13 de dezembro de 1911. Por meio da correspondência, Renato envia notícias sobre suas atividades culturais e de lazer dos últimos meses. Documento recuperado no Instituto Hercule Florence.

${ }^{30}$ Fazemos referência ao conceito de habitus defendido por Bourdieu, que quebra com a dualidade entre interioridade e exterioridade na formação de sujeitos. O habitus é o repertório de pensamentos, ações e alternativas
} 
infância de RBM que lhe conferem distinção educacional e cultural especial, numa época em que escola e lazeres "modernos", como sessões em salas de cinema do centro eram prerrogativas, em São Paulo, de crianças de meios sociais abastados.

O Colégio Macedo de Soares, em que Moraes estudou entre 1910 e 1911, dispunha de ginásio nas modalidades internato e externato. No início do século $\mathrm{XX}$, era muito comum famílias de elite colocarem seus filhos em colégios internos. A escolha do colégio estava relacionada não só aos aspectos cognitivos, mas a valores cultivados por meios sociais elitizados. Além da formação moral, havia a preocupação com a preparação para o ensino superior, privilégio quase exclusivo dos meninos, pois para meninas era importante a formação para a vida doméstica. Fazia parte do currículo da escola o ensino da língua portuguesa e também o francês.

Na publicidade do colégio, divulgada anualmente nos jornais, um dos destaques era dado ao ambiente arborizado onde se localizava, sob a justificativa de que o prédio havia sido construído propositalmente como escola. A peça publicitária fazia questão de enfatizar que os valores superiores do Colégio estavam estampados fisicamente em seus prédios. Além disso, no âmbito pedagógico,

[...] a escola [Macedo Soares] tem por fim secundar a família na educação das crianças. Consiste a sua missão, não só em lhes fazer adquirir conhecimentos e aptidões, como também lhes cultivar a inteligência, fortificar os bons sentimentos, formar caráter e favorecer o desenvolvimento físico... ${ }^{31}$ (GYMNASIO, 1917, p. 14)

A partir do anúncio feito pelo colégio, é possível notar que a escolha da instituição onde RBM foi matriculado, em 1910, não foi aleatória. Tratava-se de uma escolha seletiva e especial, destinada a círculos restritos da infância brasileira, além de uma fase de preparação para o ingresso do adolescente no Colégio de Genebra, na Suíça.

Em 1911, RBM é, pois, reenviado à Europa, com o irmão Arnaldo, desta vez para estudar no Collège de Genève, o mais antigo colégio público calvinista da Suíça ${ }^{32}$, fato determinante para a constituição do leitor curioso que foi, apaixonado pelos livros. Passou dez anos em Genebra e nesse período iniciou um caderno de registro de livros lidos. O pequeno

\footnotetext{
vislumbrados por cada indivíduo como disponíveis para sua ação, via de regra vivenciados como uma condição de liberdade quando também poderiam ser lidos como as limitações que as propriedades sociais introjetam nos indivíduos (CATANI, 2017).

${ }^{31} \mathrm{O}$ trecho é uma citação em anúncio de publicidade feito pelo colégio e publicado em 1917. O original refere-se ao primeiro artigo da lei sobre instrução no Cantão de Berna, na Suíça.

${ }^{32} \mathrm{Em} 27$ de agosto de 1912, Moraes foi matriculado no VII ano da Instrução Pública, do colégio de Genebra. Nesse momento, RBM tinha 13 anos de idade.
} 
caderno de capa azul lista obras literárias em francês, inglês e, nas últimas páginas, em português $^{33}$. Ele próprio dizia que sua base intelectual era fruto da formação no Collège de Genève: "de tanto respirar aquele ambiente, acabei intoxicado o resto da vida" (MORAES, 2011$, p. 74$)^{34}$.

Em textos memorialísticos, RBM retoma o modo como foi estimulado a formar seu gosto pela leitura, a partir de uma literatura infantil escrita no século XIX, pela escritora russa Condessa de Ségur:

Eu me lembro que os primeiros livros que eu colecionei, eu tinha talvez uns dez anos. Eram livros da Comtesse de Ségur, famosos, feitos para criança. Na época que toda criança europeia e, inclusive no Brasil, se lia muito e meu pai me comprou um. E então eu fiquei com vontade de ler outro, e então eu li o outro. E aí então eu vendo na página... parada na página de rosto todas as obras da Comtesse de Ségur, aí veio a ambição de possuir a obra completa da Comtesse de Ségur. Meu pai disse: 'Bom, então eu vou comprando você vai lendo que eu vou comprando à medida...'. Quando eu cheguei aos doze, treze anos, isso já estava combinado com Júlio Verne, com outros livros dessa época, e eu lia os meus livros sempre com muito cuidado, conservava muito bem tudo. (MORAES, 1981, p. 4)

O Colégio de Genebra foi fundado por Calvino no século XVI e oferecia aulas das 8 às 17 horas, com exceção do período de verão, quando as aulas começavam às 7 e terminavam às 18 horas. A rotina intensa de estudos atraía estudantes de diversas partes do mundo, mas poucos brasileiros, a considerar seus registros de memória que fazem referência a seu irmão Arnaldo, sobre quem, no entanto, Moraes comenta muito pouco. Alguns professores do colégio possuíam fama internacional, como foi o caso de Édouard Claparède, um dos fundadores da psicologia infantil, que viria a ser décadas depois convidado a lecionar em São Paulo, mas também Édouard Pittard e Henri de Ziegler, por quem RBM demonstra especial afeição. Nesse sentido, o capital intelectual estimulado pelo pai, juntou-se ao escolar num continuum a que poucas crianças tinham possibilidade de experimentar no país dominado pelo analfabetismo e baixa escolarização.

\footnotetext{
${ }^{33}$ No caderno não consta indicação da data de início de seu uso; apenas na página 13 , apontamento 250 , é que há a marcação "Janvier 1917". O que possivelmente indica que a leitura foi finalizada em janeiro de 1917, quando ainda estava em Genebra. A última anotação data de 6 de dezembro de 1921. No total, foram apontados 588 livros, o que segundo informações do Instituto Hercule Florence, foi o núcleo inicial de sua primeira biblioteca.

${ }^{34}$ De acordo com documentos recuperados no seu arquivo pessoal, RBM, ao longo de sua trajetória profissional, retornou mais duas vezes à Suíça, em momentos estratégicos para o desenvolvimento de seu trabalho. A primeira delas quando projetava o novo prédio da biblioteca municipal de São Paulo, que viria a ser desenvolvido por Jacques Pilon; a segunda, quando já na ONU, como diretor do Departamento de Informação, em Paris. Nas duas vezes, RBM retorna ao seu país de formação em busca de referenciais culturais.
} 
O colégio de Genebra, os cuidados do pai e da avó, constituíram, apesar das dificuldades resultantes da perda da mãe, um oligopólio na formação do habitus, desenvolvendo aptidões, estilos de vida e gostos que se reproduziriam durante a vida adulta.

Deve-se considerar a importância da escolha da cidade de Genebra como espaço formativo, por sua singular história. Historicamente ligada à França, a cidade tornou-se o abrigo da Reforma Protestante calvinista no século XVI e, no presente, ela tem o estatuto de cantão dentro da federação helvética, mais conhecida como Suíça. A soma desses fatores fazia de Genebra um lugar onde se pensava o mundo a partir da cultura francesa, mas de uma forma diferente. Ciosa de sua tradição de liberdade de pensamento, conquistada a duras penas durante as guerras religiosas da Idade Moderna, a cidade se orgulhava de pertencer a um país que permaneceu neutro mesmo durante a I Guerra Mundial e que, dentro do país, desfrutava de uma relativa autonomia pela configuração política adotada entre os suíços.

Estudar em Genebra, entre 1911 e 1917, significou para Rubens Borba de Moraes ter acesso ao que de melhor a cultura europeia poderia oferecer e permanecer à margem dos horrores do morticínio pelo qual o resto da Europa começou a passar a partir da eclosão da I Guerra Mundial, em 1914. Paradoxalmente, o conflito armado reforçou as vantagens da neutralidade suíça, condição singular, capaz de atrair pacifistas perseguidos em seus países de origem, serviços de espionagem e de diplomacia dos lados beligerantes, além de ser um dos poucos lugares da Europa em que se poderia discutir qualquer assunto livremente.

A condição geopolítica da Suíça e de Genebra, em particular, fez com que os irmãos Borba de Moraes tivessem uma oportunidade ímpar de formação, da qual Rubens soube aproveitar-se, dedicando-se à cultura francesa e a uma formação poliglota e literária como poucos brasileiros tiveram no período - em detrimento das áreas científicas e clássicas.

No Colégio Genebra, RBM estudou sete anos de alemão, quatro de inglês e dois de italiano, mas a centralidade do currículo estava no aprendizado do latim e do francês. Quanto à primeira dessas duas línguas, declara ter aprendido o suficiente para ler pequenos trechos, mas reconhece que lhe faltaria competência para decifrar o latim de seus incunábulos. Em compensação, sua paixão pela língua e pela literatura francesa desponta já nos anos finais, correspondentes ao que na época chamava-se "ensino secundário" e hoje conhecemos pelo nome de Ensino Médio, como RBM explica na passagem abaixo:

Se fui um péssimo estudante de ciências, fui um ótimo aluno de história e de literatura. Nos últimos anos fui sempre o primeiro em composição francesa. [...] O que eu ambicionava era ser escritor, historiador, professor de qualquer coisa desse gênero. Nunca um engenheiro, um advogado, um médico, ou 
exercer qualquer outra profissão. Não há dúvida que para essa descoberta de talentos ilusórios nesse meninote, esse 'petit brésilien', influíram o ambiente da casa de madame Chenou onde morava eu e meu primeiro professor de literatura francesa. Chamava-se Henri de Ziegler. (MORAES, 2011, p. 76)

Ao longo do texto memorialístico, transparece o peso das relações pessoais para a definição dos gostos do pequeno Rubens, inconscientemente em busca, talvez, de um substituto temporário para a figura paterna, distante. A atenção dedicada por de Ziegler ou recebida pelo mérito de vencer os concursos de redação em seus últimos anos de estadia no colégio, atuaram como um estímulo social para a definição de seu modo de ser, quebrando-se a corrente de reprodução das expectativas familiares e sociais de seu ambiente de origem e, assim, sendo capaz de pensar em opções profissionais extraordinárias para os horizontes dos brasileiros da época.

Enquanto os nomes ligados à cultura no Brasil viam-se na obrigação de terem várias ocupações - precisavam ser jornalistas, profissionais liberais, funcionários públicos, e muitas vezes mais de uma coisa ao mesmo tempo - para justificarem sua dedicação em tempo parcial à cultura, RBM demonstra sair de Genebra com o ânimo decidido a buscar algo que lhe permitisse dedicar-se à cultura com exclusividade. O modelo de sociedade (a suíça) onde se formou oferecia tais opções e isso parece ter marcado a história profissional e intelectual de Moraes.

Este aspecto também é fundamental para compreender como Moraes viria a se tornar um bibliotecário e, ao chegar ao Brasil, se aproximaria do grupo então "subversivo" dos modernistas e não dos portadores dos gostos já consagrados no Brasil dos anos 1920. Em outras palavras, há fatores sociais e psicológicos que dirigem o jovem Rubens a uma posição de militância intelectual potencialmente transformadora ao voltar ao Brasil e que ajudam a tornar inteligível sua escolha pelo fortalecimento de um novo campo de atuação, a Biblioteconomia.

Do ponto de vista social, o investimento financeiro familiar (por parte de seu pai, Antonio) lhe permitiu travar contato com outras formas de compreender o mundo, além de dedicar-se ao acúmulo de um extenso saber sobre a cultura tida como "a superior", pois mesmo sem ser a maior potência econômica mundial, os franceses eram vistos como o exemplo de como o Brasil poderia ser em termos culturais.

Do ponto de vista afetivo, a atenção de sua anfitriã, que segundo o próprio Moraes os tratava como filhos a ele e a seu irmão, são um elo da corrente de laços psicológicos que conformam e confirmam as escolhas do jovem rapaz. Seriam raros os lugares, mesmo em uma Pauliceia que desejava se apresentar cosmopolita (embora continuasse a ser muito provinciana), 
em que um garoto pudesse, no Brasil, ter a oportunidade que Rubens teve e que é relatado por ele abaixo:

Todas as noites, depois do jantar, reuníamo-nos no salão, ao pé do fogo da chaminé no inverno, e madame Chenou lia-nos um livro. Pelo menos umas três vezes por semana ela se sentava ao piano e tocava as grandes obras clássicas. [...] Falava-se de tudo em casa, mas, principalmente, de literatura. Quem ia a um teatro, a um concerto, a uma conferência, tinha obrigação de contar tudo direitinho e fazer a crítica. Surgiam discussões apaixonadas. Era um ambiente estimulante. Encontrei ali apoio e compreensão. (MORAES, 2011, p. 95)

Apoio e compreensão através da exposição ao que se poderia considerar como "a fina flor da cultura erudita": Moraes (2011) relata, por exemplo, que toda vez que escuta uma obra de Beethoven lembra-se com carinho de Mme Chenou. Insistimos aqui na associação entre estas três coisas: o psicológico (carinho) e o cognitivo (apreciação artística), em ambiente completamente alheio aos pressupostos da cultura brasileira. Estas são informações relevantes para compreender a trajetória de Moraes no Brasil; compreender sua atuação junto ao Departamento de Cultura de Mário, com Mário de Andrade e outros empenhados modernistas.

Entre os professores que dedicavam especial atenção ao garoto brasileiro, ressalta-se a atuação de Eugene Pittard, professor de antropologia e geologia. RBM foi convidado a compor a equipe que trabalharia no laboratório da disciplina, limpando crânios humanos e anotando suas medidas, conforme os cânones da Antropologia no período, que aceitavam as teorias raciais de diferenças entre as personalidades humanas detectáveis a partir da morfologia da cabeça. Do aprendizado com o professor Pittard, a memória de Rubens reteve, para a redação de sua biografia, outro aspecto fundamental para compreender os rumos que ajudou a conferir à Biblioteconomia, anos depois de sua volta ao Brasil:

Para mim, o importante não era essa tarefa material. Era viver num grupo, trabalhar com um mestre. Era sentir que estava colaborando com um savant, que estava aprendendo o ofício de pesquisador. [...] O resultado geral de todos aqueles trabalhos não me competia, não me interessava. Era a tarefa do mestre, não a minha. Quando analiso hoje essa minha tendência para fazer trabalhos que demandam longas pesquisas, a sentir prazer somente em procurar dados e reuni-los sem me preocupar com as interpretações que poderia tirar, perguntome se essa propensão não teve origem no laboratório de antropologia. No fundo o que faço redigindo laboriosamente e com imenso prazer uma bibliografia é procurar repetir a sensação agradável que sentia na mocidade. (MORAES, 2011, p. 80) 
$\mathrm{Na}$ passagem de onde este trecho foi retirado, Rubens Borba de Moraes constrói seu argumento em duplo movimento: em uma direção, conduz o leitor a pensar como "o menino foi o pai do homem", para retomar, de forma aligeirada, o argumento freudiano. Moraes tinha nos professores um modelo de figura paterna e na equipe de laboratório um elemento de socialização que compensava em alguma medida sua condição familiar da qual se encontrava exilado. Assim, desenvolve o gosto pela pesquisa erudita pelo resto de sua vida. Pittard lhe ensina os prazeres de participar da "comunidade dos sábios", Ziegler desperta sua paixão pelos livros e, adiantando-se às próximas partes da tese, Mário de Andrade lhe mostra o caminho para converter esse saber (não apenas no sentido cognitivo, mas no sentido de "ter a experiência de") em uma paixão pelo Brasil.

Na outra direção, o argumento se constrói no sentido de antecipar a possível crítica de que o trabalho do bibliotecário é "menor", menos autoral do que os outros profissionais ligados à cultura. A passagem citada já posiciona a produção de catálogos e manuais bibliográficos como um "laborioso" e generoso preparo de "matéria-prima" (termos do próprio Rubens) para que outros possam também exercer sua autoria. Na sequência, arremata: "O que me dá prazer de fato é procurar, pesquisar e achar. O resto é uma questão de redação. Acho penoso e maçante escrever o que já sei” (MORAES, 2011, p. 81).

A frase apresenta a chave de ouro para uma nova definição do que é ser bibliotecário. Não é por falta de conhecimento que o bibliotecário bibliófilo se completa de bibliografias e outros instrumentos de pesquisa; é sua generosidade e sua dedicação à pesquisa que lhe permitem ir além dos limites de uma pesquisa estritamente individual e pensar em propiciar os materiais de trabalho para os outros especialistas do tema. Os resultados obtidos pelos bibliotecários assumem, nesta visão, o papel de pedra angular da construção de outros arquitetos do conhecimento, com atuação autoral de instrumentos e recursos de mediação cultural que são um terceiro ponto essencial dos processos sociais de significação.

Além da escola, é também em bibliotecas, museus e livrarias suíças que Moraes desenvolve a base de seu repertório cultural. Nesse período, frequentou tais ambientes com regularidade, o que pode indicar, segundo Bandeira (2007), que sua relação com a arte tenha aflorado aí.

Igualmente importante, é mencionar a relação emocional com o pai nesse período. Todas as vezes em que descreve o que viveu em terras francófonas, tem como evocativo a figura de um pai que zelou por sua formação. Apesar do pouco tempo vivido com ele, são notáveis as vezes que cita livros e indicações de leituras que envolvem a figura paterna, o que confirma a tese de que as figuras de pai e de professor se confundem na construção memorialística de 
RBM. Lembranças referidas com maior frequência, quando já se encontrava retirado em sua casa em Bragança Paulista, onde viveu no final da vida. Da mesma forma, outra pessoa da qual relembra com frequência é sua avó materna. Mais do que consanguinidade temporal, vemos que há entre eles um relacionamento discipular.

Podemos dizer que o repertório cultural de Moraes, desenvolvido por meio das relações com seu pai, professores, anfitriã genebrina (Mme Chenou) e avó materna, teve seu núcleo nos livros, na leitura e nas relações que, por causa deles, foram estabelecidas. Agrupados em coleções, seus livros ganhavam sentidos que ultrapassavam os aspectos físicos do objeto. Não que isso fosse suficiente para justificar sua trajetória intelectual e profissional, mas é notável que a relação com os livros foi muito além da relação com a materialidade do objeto.

Quando perguntado sobre quando começou sua paixão pelos livros, fez questão de falar que sua vida se construiu no meio deles (MORAES, 1975), ou seja, por meio dos livros, RBM encontrou seu modo de se colocar no mundo; enquanto formava suas coleções, construía seu espírito (MELOT, 2019). Aos 20 anos, diferentemente da maioria de seus antecessores familiares, irmãos e primos, que tinham como tradição viajar aos Estados Unidos para formação na área das Engenharias, RBM era um intelectual ligado aos livros, ao mundo da literatura, da cultura letrada e da Universidade.

Quando desembarcou no Brasil, em 19 de setembro de 1919, RBM encontrou um país mudado (MORAES, 2011). Segundo ele próprio, se antes a terra exaltava a supremacia europeia, naquele momento passava a marginalizar os que retornavam depois de passar um tempo na Europa ou nos Estados Unidos. O adjetivo estrangeiro, segundo ele, teria se transformado em termo pejorativo, indicativo de marginalização. Atribuía tal fato a vestígios da Primeira Guerra Mundial. Outra diferença, que atingiria diretamente diferentes camadas da sociedade, era que o país estava cada vez mais burocrático, por causa da segurança pública.

Se para sair do Brasil, RBM precisou apenas de um cartão de visitas, na volta, para circular por ele com sotaque estrangeiro, era necessária "uma carta de escravo do Estado moderno" - o documento de identidade que, ao mesmo tempo, assegurava a submissão ao controle do Estado contemporâneo sobre o cidadão e a consecutiva autorização para seguir em liberdade (condicional e vigiada). Portador de um espírito genebrino cioso de suas liberdades individuais, RBM viu-se de volta a um território esquadrinhado pela cultura do coronelismo, a permitir que "a" autoridade (no singular, característica de uma promiscuidade entre público e privado, entre o que era da ordem do político, do econômico e do cultural). Segundo as declarações do próprio RBM, seu temor de viver uma vida sem liberdade o levou a considerar 
sedutora a vida do intelectual, visto que a classe dos intelectuais, segundo ele, foi a única livre por muito tempo (MORAES, 2011).

Ao chegar ao Brasil, RBM manifestou interesse em conhecer a literatura e a cultura nacionais. Na casa de sua avó materna, na fazenda Atalaia, matou a curiosidade pela literatura brasileira. Registros dessa narrativa apontada em suas memórias coincidem com as de seu caderno de leituras; o caderno azul encontrado em seu arquivo pessoal. Nele, as anotações de leituras de autores brasileiros começam a aparecer em 1919 e vão até setembro de 1921, quando termina o caderno. Dentre os escritores de língua portuguesa estão Eça de Queiroz, Machado de Assis, Aluízio de Azevedo, Viriato Correa, Menotti del Picchia, Afrânio Peixoto, Graça Aranha e Godofredo Rangel. Há também na lista Os Sertões de Euclides da Cunha.

Entretanto, RBM não só se envolveu com textos em língua portuguesa como se interessou por livros de história do Brasil. O primeiro que comenta em suas memórias é de Francisco Adolfo de Varnhagen (1816 - 1878), um estudioso sobre o passado do país, que percorreu arquivos e bibliotecas, a fim de pesquisar materiais sobre o período colonial do Brasil. Varnhagen, um dos fundadores do Instituto Histórico e Geográfico Brasileiro chegou a publicar textos que o identificavam apenas como membro do instituto.

Ainda no campo da história, comenta que, ao ler As populações meridionais do Brasil, de 1920 de Oliveira Vianna, notou atraso no determinismo sobre as quais estava alicerçada sua apreciação sobre a história nacional. Com isso, não hesitou em lançar críticas às bases utilizadas pelo autor para interpretar São Paulo. Segundo ele, as teorias já estavam ultrapassadas na Europa. Essa declaração de RBM ganha vigor renovado quando se recorda que, após novo giro das rodas da história, o desconforto com as teses autoritárias do pensamento social de Oliveira Vianna voltaria a aparecer com a implantação do Estado Novo, nesta feita retraduzidas em algo bastante mais concreto do que a leitura sobre o passado brasileiro, pois as dificuldades em aceitar a mudança no trato da coisa pública, em especial no tocante às políticas culturais, possuem também suas raízes teóricas ${ }^{35}$.

Ainda com a indicação da avó, RBM procurou Mário de Andrade em uma das vezes que foi a São Paulo. Dessa amizade começou uma nova fase de relacionamento com a cultura brasileira, desta vez mediada pela interlocução com o autor de Macunaíma e com outros membros do círculo modernista.

\footnotetext{
${ }^{35}$ Para ver mais detalhes sobre as dificuldades enfrentadas por Rubens Borba de Moraes após o Golpe de 10 de novembro de 1937, verificar item 4.4 da presente tese e, em sentido mais lato, todo o capítulo seguinte. Por ora, cabe apenas informar que Francisco Campos, autor da Constituição de 1937, era leitor de Oliveira Vianna, e que os pressupostos legislativos dessa Carta Magna representaram uma negação do projeto de cultura política que permitia o funcionamento do Departamento de Cultura e de sua política cultural revolucionária.
} 


\subsection{Uma comunidade de saberes}

Em 1919, enquanto a cidade de São Paulo ampliava seu caminho de urbanização, um grupo de jovens ligados às letras buscava espaço na sociedade para pensar, discutir e escrever de forma livre sobre artes, política e sobre eles mesmos. Dentro desse grupo estavam Mário de Andrade, Oswald de Andrade ${ }^{36}$, Guilherme de Almeida, Di Cavalcanti, Sergio Milliet, Anita Malfatti, Luís Aranha, entre outros. A eles, juntou-se Rubens Borba de Moraes, jovem também, recém-chegado ao Brasil.

Se cada um desses jovens tinha desenvolvido seu modo especial de se relacionar com a arte, Rubens Borba de Moraes, Mário de Andrade e Sérgio Milliet tinham ligações especiais não só com as letras, mas também com o patrimônio literário e, por extensão, estavam atentos à questão das bibliotecas. Dados os objetivos deste trabalho, fixaremos nossa atenção, portanto, nestas relações envolvendo os destinos da cultura letrada no país, tendo em vista compreender movimentos do grupo que favoreceram e colocaram-lhes em lugar de destaque na construção de um campo institucional de ação e reflexão letrado, instância até então inexistente no país.

Rubens Borba de Moraes voltara da Suíça formado em Letras, e encontrou no grupo eco às suas veleidades literárias e culturais. Seu rito de entrada no círculo intelectual paulista foi coordenado por Mário de Andrade, que tinha relações antigas com a família de Moraes, pois ambas eram proprietárias de terras em Araraquara, tanto a família de Moraes como a de Andrade. A avó de Rubens era amiga da família de Mário de Andrade e o avô de Mário, Dr. Joaquim de Almeida Leite Moraes, parente distante do pai seu pai.

Ao chegar ao Brasil, RBM vinha com um cartão de visitas: a publicação da peça de teatro "Le Chevalier au Barizel: drame en 3 actes et 4 tableaux", escrita juntamente com Constant Bourquin e Robert Bernard. A peça em três atos tinha sido encenada, no dia 19 de fevereiro, no principal teatro de Genebra, o Thêatre de Plainpalais. Seu encontro com Mário de Andrade serviu de incentivo para alavancar seus estudos de literatura nacional e sobre o país.

Mário de Andrade, com formação em Letras e no Conservatório, dava aulas de música e tinha transformado sua casa em um espaço de fomento a aspirações literárias. Os encontros de trocas de leituras e discussões literárias serviam de referencial não só para a classe intelectual de São Paulo - artistas, músicos e escritores - como também para intelectuais de passagem pela cidade. Ou seja, o reconhecimento da comunidade que se formava era atestado não só pela elite

\footnotetext{
${ }^{36}$ Moraes refere-se a Oswald como Oswaldo, nome pelo qual era conhecido dentro do grupo de modernistas.
} 
cultural e social paulistana, como também pela classe intelectual de outros estados e, também, estrangeira.

Moraes retoma nas memórias o repertório de leituras que introduziu no grupo com o qual passou a conviver, constituído de obras de Lafargue, Villiers de l'Isle Adam, Huysmans, Apollinaire, Claudel, Cocteau, Blaise Cendrars, Max Jacob, entre outros autores. Além de fornecer, por meio de sua biblioteca particular, livros que não se encontravam facilmente nas livrarias de São Paulo, disponibilizou para seu circuito revistas das publicações de Henri Barbusse e do grupo Clarté, das quais tinha assinatura. De acordo com Mindlin (1998a), Rubens foi um dos primeiros a ler Proust, em São Paulo. Por outro lado, enquanto fornecia seu acervo filosófico, literário, político-social, recebia apoio especial de Mário de Andrade no processo de apropriação de textos da literatura brasileira ${ }^{37}$.

Foi nos "lindus" 38 de Mário de Andrade, às terças-feiras à noite, na Rua Lopes Chaves, no bairro da Barra Funda, em São Paulo, que se discutiram ideias, se debateram princípios, se estabeleceram caminhos estéticos do movimento que revolucionou a literatura e a arte brasileira em geral. Ao rememorar as origens do movimento modernista, Rubens conta que a ideia para a realização da Semana de Arte Moderna teria partido de Di Cavalcanti. Segundo ele, o pintor necessitava quitar suas dívidas. Então, com a ajuda dos amigos, organizou uma exposição de suas obras. Contudo, o evento foi um fracasso nas vendas.

Sem dinheiro, Di Cavalcanti resolveu que exposição individual era coisa do passado, era preciso uma grande exposição de arte moderna, um salon des indépendants, para sacudir a indiferença do público. Foi na fracassada exposição individual de Di Cavalcanti que os modernistas conheceram Graça Aranha. Com a autoridade de um capitão inspecionando a tropa, nas palavras de Moraes, Graça incentivou a ideia da Semana de Arte Moderna e orquestrou um encontro com Paulo Prado para a organização e levantamento de recursos para o evento, além de apresentar os modernistas do Rio de Janeiro aos paulistas.

A aproximação com o grupo de jovens intelectuais e artistas que fariam a Semana de Arte Moderna na capital paulista, despertou em RBM um interesse pela política cultural da cidade de São Paulo, que se estabelecia como capital da industrialização do país.

A Semana de Arte Moderna de 1922 ocorreu entre os dias 11 e 18 de fevereiro, no Teatro Municipal de São Paulo, e foi a concretização do sentimento de modernidade idealizada por

\footnotetext{
${ }^{37}$ Rubens Borba de Moraes tinha dificuldades com a língua portuguesa. Para ele era mais fácil se expressar em francês que na sua língua materna. Aconselhado por Mário de Andrade, tomou aulas de português com o professor Marques da Cruz, durante um ano.

${ }^{38}$ As reuniões na casa de Mário de Andrade eram chamadas de "Lindus do Mário”, por Di Cavalcanti.
} 
uma parcela da intelectualidade paulista, somada a outras forças de procedências diversificadas no país, como os cariocas Graça Aranha e Heitor Villa-Lobos. Rubens Borba de Moraes participou da idealização e preparação do evento, mas poucos dias antes, foi diagnosticado com tifo $^{39}$, o que o impediu de estar presente na Semana.

Entre tentativas de compreender suas raízes e de buscar um modo singular de viver é que aparecem, portanto, as problematizações a respeito do livro, da leitura e das bibliotecas para os jovens modernistas em questão. A problemática geral da cultura letrada e da cultura, de forma ampla, inscreve-se, assim, numa perspectiva de construção nacional que extrapola dimensões meramente individuais ou idiossincráticas. A formação da Biblioteconomia, como se verá, é fruto dessa dinâmica de afirmação e de construção da brasilidade e, nesse sentido, tal qual Candido (1969) afirma, ao tratar da literatura brasileira, trata-se de manifestação "empenhada", isto é, vinculada a questões político-culturais que regulam a vida nacional.

\subsection{Ingresso no universo da difusão cultural}

A movimentação dos modernistas não se encerrou com a concretização da Semana de Arte Moderna. O grupo inicial continuou a se reunir na casa de Paulo Duarte, na Avenida São João. Juntos idealizaram a Klaxon, revista editada durante nove meses (de 15 maio de 1922 a janeiro de 1923), subsidiada pelos próprios criadores e que tinha como objetivo a difusão das ideias do grupo. Para Moraes, a Klaxon era uma forma "divertida" e "agradável" de discutir ideias (MORAES, 2011). Ainda em 1923, com o fim da revista, Rubens e Tasso da Silveira $\left(1895\right.$ - 1968) ${ }^{40}$ fundaram a editora "Candeia Azul” (CASTELLO, 1999). Em 1924, Moraes ingressa em nova ação no campo da Editoração, ligando-se sempre a questões da cultura escrita no país. Primeiro, trabalhou na edição do Anuário do Brasil, com Tasso da Silveira. Depois, na criação e edição da revista de cultura e literatura Terra Roxa e Outras Terras (1926), que teve como diretor Antônio Carlos Couto de Barros e Antonio Alcântara Machado, além de Sérgio Milliet, encarregado da secretaria. Na publicação do primeiro número da revista, anunciavam a edição da Biblioteca Histórica Brasileira que, a partir de 1941, seria organizada por Rubens Borba de Moraes, em evidente ação que revela suas preocupações com a memória do país,

\footnotetext{
${ }^{39}$ Cf. DUARTE, P. Mário de Andrade por ele mesmo. 2.ed. São Paulo: HUCITEC, 1985.

${ }^{40}$ Tasso Azevedo da Silveira, bacharel em Direito pela Faculdade de Ciências Jurídicas e Sociais, foi um poeta e editor ligado à segunda geração de modernistas. Da ala espiritualista do modernismo, ao lado de Tristão de Ataíde e Cecília Meireles, atuou em revistas como "Os novos", Árvore Nova, Terra do Sol, América Latina e Cadernos da Hora Presente. Além de colaborar em jornais como O momento, Rio-Jornal, A Manhã e Revista Sul-americana, e ainda participar da fundação da revista Festa e secretariar os jornais O Estado e o Diário da Tarde; foi também redator do Diário da Manhã. Na década de 1930, é eleito deputado estadual em Curitiba/PR.
} 
enquanto elemento de afirmação identitária. A coleção, editada pela Livraria Martins, contou com a direção de RBM e se especializou na publicação de relatos de viajantes nos períodos da Colônia e Império.

Em 1928, lança o primeiro número da revista Antropofagia que, um ano mais tarde, seria vendida ao jornal $O$ Diário, cujo dono era Assis Chateaubriand. Nesse momento, Moraes já acumulara experiência de leitor, crítico, escritor e editor ${ }^{41}$, ou seja, tornara-se um homem das letras, imerso em diferentes papéis e dinâmicas, tendo em vista a constituição de trama institucional que dá objetividade e contorno à manifestação da escrita, entendida não apenas como conjunto de textos, mas como "cultura letrada", isto é, conjunto de práticas, de objetos, de instituições, de modos de atuar, de comunicar, de refletir, de produzir diretamente ligados à utilização dos sistemas escritos (CHARTIER, 1994).

A preocupação do grupo com o tema da nacionalidade e a relação entre cultura popular, intelectuais e projeto nacional desaguou no envolvimento de alguns membros - inclusive RBM - na política partidária e nos movimentos armados ou não, que chacoalharam o cenário político brasileiro no período.

\subsection{RBM, intelectual e político}

Klaxon pode servir como marco de mudança entre o movimento artístico-cultural de rompimento com o conformismo cultural burguês e o movimento em que RBM enveredaria pela política nacional estrita. Assim, junto a outros participantes da revista, Moraes atuou na fundação e da organização do Partido Democrático ${ }^{42}$, conforme ele próprio relata. Assim, RBM afirma ter participado desde a primeira reunião para criação do partido, no dia 31 de agosto de 1924, na casa de Paulo Nogueira Filho, com quem já havia trabalhado na revista Klaxon. Várias reuniões estão na origem da criação do Partido Democrático, ocorrida em 1926; RBM afirma que o interesse em unir o grupo era "lutar contra a corrupção eleitoral e o coronelismo brasileiro" (MORAES, 2011, p. 214). Também colaboraram outros nomes, envolvidos com a

\footnotetext{
${ }^{41}$ Moraes já tinha publicado as obras "Le Chevalier au Barizel”, em 1919, e "O domingo dos séculos”, em 1924, além de artigos na Revista Klaxon.

${ }^{42} \mathrm{O}$ Partido Democrático (PD) surgiu como uma dissidência do Partido Republicano Paulista (PRP), herdeiro dos arranjos entre as elites estaduais realizados para trazer estabilidade à Primeira República, após os anos iniciais de governo dos militares Deodoro da Fonseca e Floriano Peixoto. O PRP, como todos os outros partidos republicanos estaduais, era talhado de modo a combinar uma estrutura municipal tensionada pela disputa da liderança entre os coronéis locais e o estabelecimento de uma série de alianças entre os vencedores destas disputas e os grupos no comando dos executivos estadual (o Presidente do Estado) e federal (o Presidente da República). O PD surge para pôr em xeque as práticas que permitiam a manutenção desse status quo, como o fisiologismo e a realização de eleições fraudadas, com voto aberto.
} 
revista Klaxon, já então fora de circulação: Mário de Andrade e os campineiros Tácito de Almeida - irmão de Guilherme de Almeida - e Antonio Carlos Couto de Barros, sócios de uma banca de advocacia. Juntos, ajudavam a compor o grupo dos profissionais liberais que aderiram ao Partido Democrático, com vistas a defender uma proposta que, conforme o manifesto fundador, pugnasse pelo voto secreto, pela criação de um sistema judiciário independente, "pela independência econômica do magistério público e pela criação de um organismo integral de instrução, abrangendo o ensino primário, secundário, profissional e superior" (RAMOS, 2009). $\mathrm{O}$ interesse do manifesto pela educação converge e soma-se à preocupação manifestada por RBM na época, acerca do resgate, preservação e divulgação da memória cultural nacional, como condição de construção de novos padrões identitários, afinados com a modernidade e o progresso social e cultural.

Enquanto os jovens modernistas se organizavam em torno das artes, emergiam também em São Paulo movimentos sociais de trabalhadores têxteis, sapateiros, gráficos, padeiros, metalúrgicos e operários. Segundo Lilia Schwarcz (2010), entre 1919 e 1920, a capital de São Paulo foi palco de 64 greves. Dentre as reivindicações estavam as condições de trabalho e jornada abusiva. Reclamavam das péssimas condições de trabalho que permitiam que crianças de 5 anos de idade se sacrificassem nas fábricas da cidade. Havia, de fato, um grande contingente de mulheres e crianças na indústria, o que, segundo esta autora, chegava à metade dos empregados, fato que contribuía para rebaixar salários (SCHWARCZ, 2010).

Novos protagonistas surgiam, portanto, no cenário brasileiro, assumindo um papel importante na problematização da situação política, social e cultural do país. Desde a proclamação da República, o Brasil via-se dividido, assim, entre a afirmação de suas raízes e a busca pela modernidade, entre o "arcaico" e o "moderno". Nesse jogo entre forças que se apresentavam como contrárias, havia uma movimentação em torno da busca da identidade nacional, seja por vias centrípetas ou centrífugas. Em nenhuma perspectiva era possível, todavia, ver o Brasil como um quadro humano homogêneo étnica e culturalmente, como atribuído à maioria das nações que serviam como referência de civilização ao país. Isso remetia, portanto, à necessidade de apreender intelectualmente as características do presente do país, a fim de que se viabilizassem outros futuros possíveis para ele (CERQUEIRA, 2010).

Em 1931, RBM publica o livro Só separando, no qual arquiteta uma análise política daquele momento do qual resulta a defesa de um descolamento da administração paulista em relação ao resto do país. E ainda, ele e Tácito de Almeida continuam a atuar juntos na fundação da Liga de Defesa Paulista, com um tom regionalista que buscava "abafar dissídios e ressentimentos resultantes de antigas lutas partidárias, a fim de obter a união da família 
paulista" (MORAES, 2011). Para compreender as palavras de Moraes, é preciso lê-las à luz dos acontecimentos políticos ocorridos no intenso período entre 1930 e 1932. Membro fundador do PD, RBM se associa a este na campanha pela Aliança Liberal, durante as eleições de 1930. Entretanto, a Revolução subsequente o decepciona, ao conferir o controle do Executivo paulista a um "tenente", isto é, um militar forasteiro aos olhos das elites locais. Os desentendimentos entre o interventor e o PD levam este último (inclusive o próprio RBM) a buscar a unidade com seus antigos opositores do PRP - um movimento traduzido, na prosa de Moraes, como "a união da família paulista”.

Essa proposta desembocou na Frente Única Paulista (FUP), responsável pela articulação da Revolução Constitucionalista de 1932, da qual RBM participou como combatente na cidade de Cunha, no vale do Paraíba, em São Paulo. Essa experiência foi avaliada a posteriori como uma grande desilusão, em todos os sentidos, como é possível ler no trecho seguinte:

Não há heroísmo em matar pobres diabos que estão padecendo o que você padece, suarentos e fedidos como você, enganados como você pelos discursos dos que ficaram confortavelmente em casa, falando, falando, falando. Quando a guerra acaba, o soldado que escapou da mutilação, da psicose e da morte volta para casa $[$ a fim de] recomeçar duramente a vida. Só os políticos ganham com a guerra. Se a liberdade custa a morte, então que morra a liberdade! Tudo, qualquer solução, menos a guerra, a matança organizada. Tudo, menos a bagunça da revolução! [...] É mentira que a guerra e as revoluções salvam a Justiça e a Liberdade. É o contrário que acontece. Ela mata a Justiça, destrói a Liberdade. (MORAES, 2011, p. 215)

É possível enxergar que RBM, entre outros, acreditava anteriormente na "revolução" (linguagem da época para qualquer movimentação militar) e se decepcionou profundamente. Esta decepção é descrita como algo que provoca asco e faz combaterem como inimigos dois grupos de pessoas que vivem a mesma situação, um raciocínio cuja formulação exige grande dose de empatia com a alteridade. Os grandes ideais, construídos com letras maiúsculas, dão a vez ao cotidiano dos enfrentamentos militares que sacrificam tudo, desde as normas higiênicas ("suarentos e fedidos") até a dignidade humana.

Note-se também a contrariedade com o grupo de políticos dos quais RBM até então se aproximara em suas ações - "os que ficam confortavelmente em casa falando, falando, falando". Há um reconhecimento de que a luta armada não é compreendida por ele como um meio para se chegar à sociedade almejada, movida pelos ideais de justiça e liberdade. Mas então qual seria este caminho?

A experiência como combatente em Cunha, da qual RBM não gosta de se lembrar, e não tece comentários em suas manifestações públicas, pode, entretanto, ser lida como um ponto 
de inflexão rumo à elaboração de novas estratégias de participação na construção da Nação brasileira. Os anos seguintes trariam a RBM oportunidades de pôr em prática seus anseios e novas estratégias políticas, através de sua atuação, via máquina estatal, na esfera da cultura. Cultura e política passam a se articular mediadas pelo Estado e a luta se fará a partir do interior dos aparelhos estatais, então em constituição, com a emergência da era Vargas.

\subsection{Da bibliofilia à "ordem dos livros"}

Se a bibliofilia é um dos descritores que marcaram a trajetória de vida de Rubens Borba de Moraes, sua paixão pelos livros o articulou à constituição da ordem dos livros (CHARTIER, 1994), em processo de estabelecimento no país, dadas as precariedades do contexto brasileiro e paulista. O que o motivou a interessar-se por obras sobre o Brasil, no primeiro momento, foi o desejo pessoal de saber sobre a formação do país, de constituição de sua própria "identidade brasileira", uma vez que vivera longos anos de formação na Europa.

Entretanto, seu projeto esbarrou na escassez de obras e na dificuldade de encontrá-las. Naquele momento, São Paulo estava ainda em processo de estruturação de seu mercado editorial (SORÁ, 2010), o que dificultava o acesso desejado aos livros. Isso o motivou a mudar o foco da coleção que havia iniciado na Europa. Assim, ainda no início da década de vinte, resolveu vender parte de sua biblioteca - nesse caso, um acervo francês - a José Olympio, livreiro da Livraria Garraux (MORAES, 2011). Investiu o dinheiro em livros sobre a Capitania de São Vicente e outros relacionados à história nacional.

Foi a partir daquele momento, portanto, que iniciou uma coleção sobre o Brasil, com impressos dos séculos XVI e XIX, e livros de autores brasileiros, impressos no estrangeiro até 1808, quando foi criada no Brasil a Impressão Régia, filial da editora de mesmo nome, em Portugal.

Para melhor contextualização e compreensão dos sentidos da bibliofilia para Rubens Borba de Moraes, é preciso, talvez, fazer uma reflexão sobre a relação de sujeitos com seus objetos de coleção, em especial elementos sociais inerentes à relação particular do colecionador com seu objeto de interesse.

Kopyroff (2003) organizaram estudos sobre a rede de significações e valores que envolvem os objetos e extrapolam o valor econômico a eles atribuídos. Nessa perspectiva, apresentam quatro níveis de vínculos das pessoas com os objetos. No primeiro, está o nível utilitário, que analisa se o objeto cumpre a finalidade a que foi criado. No segundo, a relação está pautada no uso do objeto, mais precisamente nas mudanças que ele produz quando usado. 
Como exemplo, podemos citar os instrumentos musicais que, ao serem tocados, modificam os sentimentos das pessoas que estão no ambiente. Neste caso, as pessoas se relacionam com o objeto na expectativa de produzir mudanças no ambiente. Os aspectos simbólicos dos objetos aparecem no terceiro e no quarto níveis. Como destaques do terceiro nível estão os vínculos estabelecidos entre objeto e possuidor por meio de linguagens e imagens. No quarto nível, está a acumulação, a bibliofilia, que pode se dar por meios simbólicos, não necessariamente ligados à materialidade ou ao conteúdo do livro (KOPYROFF, 2003).

Esta função social da bibliofilia, mesmo com seu caráter particular, estaria relacionada à possibilidade de ela preservar fontes que possam contribuir para que as novas gerações conheçam melhor o seu passado. O que se torna mais evidente, quando estas coleções acabam integrando o patrimônio de alguma instituição pública, como é o caso dos 30 mil volumes da coleção do paulista José Mindlin sobre o Brasil, há alguns anos, disponibilizada à Universidade de São Paulo.

Para Reifscheinder (2011), a bibliofilia pode ser entendida a partir de duas motivações: a primeira sendo consequência dos estudos e a segunda como fruto da bibliomania. A primeira refere-se ao interesse por determinada área do conhecimento, oriundo de curiosidade ou necessidade profissional. Já a segunda diz respeito ao impulso de colecionar livros por desejo de tê-los como objeto de posse, não importando necessariamente o valor cultural da coleção, mas sim o prazer por colecionar algo de difícil acesso (COSTA, 2009).

Ao falar de sua bibliofilia em $O$ Bibliófilo Aprendiz (MORAES, 2005), a relaciona ao amor pela leitura, iniciado na infância. Seu processo de colecionar livros é motivado por sua necessidade de se compreender e de pertencimento, de se ver inserido numa cultura que é sua, mas onde, por falta de contextos adequados, é difícil exercer atividades letradas; condição que o faz sentir-se um outsider em seu próprio país.

Assim, depois de uma vida em certo sentido "nômade" (com a avó, no interior, com o pai em Santos, no Paraná, em Paris, em São Paulo, no colégio interno na Suíça), ao se estabelecer no Brasil, RBM viu-se perdido social e culturalmente, fazendo desse estranhamento mote para sua atuação pública e profissional. Por ter origem em família dona de terras e ligada ao cultivo do café, no âmbito financeiro não teve grandes dificuldades, pois ainda tinha parte de uma herança que anos mais tarde serviria para a compra de um cargo na Recebedoria de Rendas (MORAES, 2011). O lado social foi resolvido de certa forma, quando, com a ajuda de sua avó materna, resgatou relações com Mário de Andrade. Este orientou o encontro de RBM com sua cultura de origem que teria, no entanto, que ser (re)feita. 
A retomada da amizade de RBM com Mário de Andrade, foi, assim, para Mário, oportunidade para o contato com ideias recentes que o velho amigo trazia da Europa, ou seja, um repertório intelectual de ponta, almejado pelos homens das letras empenhados com a modernização do país, o reconhecimento do fazer cultural letrado, em sociedade dominada ainda pelos padrões advindos da colonização e que, para dizer o mínimo, acantonaram as manifestações letradas à esfera das Belas Letras.

A leitura do contexto nos leva a observar que, se o recém-chegado à Pauliceia teve sua bibliofilia impulsionada por interesses pessoais de compreensão de si, de suas origens, bem como de sobrevivência e pertencimento cultural, os vínculos de amizade com Mário e seu círculo, aliados às condições do país, levaram Moraes a mudar o foco de sua coleção, voltandoa para o interesse social e público. Consciente de suas opções, Moraes atribui tal mudança à escassa oferta de livros no país, à precariedade cultural letrada reinante entre nós, nos anos 1920, somando-se a isso a problematização identitária que o marcou e ao país que encontrou em seu retorno de longos anos de formação na Europa.

Nesse sentido, além das questões pessoais, o contexto social e editorial do país também nos ajuda a compreender a bibliofilia de RBM sob aspectos que transitam entre o pessoal e o sociocultural, entre interesses pessoais e político-culturais, a partir do estabelecimento de relações do livro enquanto instrumento de mobilização da sociedade (BAUDRILLARD, 1993). Nesse sentido, além dos aspectos psicológicos, que dizem respeito à personalidade e à identidade do colecionador, está em causa a identidade cultural dos leitores, seres pertencentes a uma comunidade cujos laços se estabelecem na dimensão simbólica.

Reifschneider (2011) observa que é justamente essa junção que faria de Moraes o bibliófilo brasileiro mais completo, pois ele tinha os livros como hobby pessoal e também como objeto de ação pública e social. Podemos somar a tal ideia o fato de que a singularidade de RBM pode estar vinculada à razão segundo a qual sua bibliofilia extrapolou a esfera particular para estar a serviço de um desenvolvimento cultural nacional que, segundo ele, não existia no país, mas que o país necessitava que existisse.

Moraes carregava em sua bagagem experiências com sua biblioteca pessoal e as vivências de bibliotecas universitárias e públicas as quais frequentara assiduamente quando morava na Suíça. Ao retornar ao Brasil, o desejo por compreender a história e cultura nacionais o fez interessar-se pela biblioteca como um instrumento patrimonial da cultura brasileira, mas também essencial à constituição de identidades "modernas", o que equivaleria dizer a "identidades letradas", como a sua. Ao falar da formação do acervo de sua biblioteca particular e também da biblioteca pública, atribui, às coleções um valor identitário individual e social, 
pessoal e político-cultural. Tratava-se de construção de sujeitos e de uma nação situados na contemporaneidade, em diálogo com o mundo, mas independentes e autônomos. Os livros e a biblioteca ganhavam, assim, a dimensão empenhada que pôs em relevo a intencionalidade dos modernistas em se posicionar a respeito dos problemas nacionais, a partir da trincheira da cultura.

Nesse sentido, RBM, muito além de ser o intelectual que saía de sua "torre de marfim" e entrava para as políticas públicas, é a encarnação, junto de outros contemporâneos importantes, de um momento que significou um corte paradigmático nas dinâmicas culturais do país. Mais que a inclusão da biblioteca como preocupação a ser incluída na agenda educacional e cultural do país, as ações protagonizadas por Moraes apontam para a instauração no país de processos que mais tarde ficaram conhecidos sob o nome de democratização cultural via ações de políticas públicas pelo Estado. A biblioteca representava até o momento, no país, poder para uns e paixão para outros, colecionismo e preservação, culto mítico do passado, desvinculado do presente e do futuro. O Departamento de Cultura e a Divisão de Bibliotecas significaram outra direção: além de colocar o passado no âmbito das políticas públicas de educação e cultura, significou o reconhecimento da biblioteca como instituição especial de democratização da cultura letrada, num Brasil que se pretendia moderno e autônomo.

\subsection{O bibliotecário modernista: conhecimento em ação}

Entre os anos de 1931 e 1934, como já mencionamos, parte do grupo de intelectuais da Klaxon e Terra Roxa e Outras Terras, continuava a se reunir na residência de Paulo Duarte. O grupo idealizava a criação de um Instituto Paulista de Cultura. Às vésperas de ver o sonho do 
Instituto concretizado, após a indicação, por Armando Salles de Oliveira ${ }^{43}$, de Fábio Prado ${ }^{44}$ à prefeitura de São Paulo, Paulo Duarte apresentou a este o texto do projeto que viria a ser aprovado pelo ato 861, de 30 de maio de 1935 e consolidado em 1936. Foi criado, assim, o Departamento de Cultura, tendo em sua Direção, Mário de Andrade.

A trajetória de Moraes com os livros e as bibliotecas apontam algumas pistas para o entendimento de sua escolha como responsável pela Divisão de Bibliotecas, quando da criação do Departamento de Cultura. A primeira delas está relacionada, sem dúvida, à sua bibliofilia; a segunda, ao seu perfil de bibliógrafo; a terceira, à sua capacidade de se comunicar com grupos ligados ao universo do livro; a quarta, ao fato de ter desempenhado um papel de bibliotecário de referência para o grupo. Soma-se a essas sua concepção "moderna" de ver a biblioteca e os livros. Estes não são apenas documentos a serem preservados em instituições autorreferentes, fechadas sobre si mesmas. Moraes alia ao sentido preservacionista um sentido "moderno" de difusão cultural e que ultrapassava gostos pessoais ou, ainda, tradicionalistas de culto à memória social tomada abstratamente.

Se o texto final de criação do Departamento de Cultura foi escrito por Mário de Andrade e Paulo Duarte, recebendo comentários de Plínio Barreto, Anhaia Melo, Júlio de Mesquita Filho, F. E. Fonseca Teles, Fernando de Azevedo, Antônio de Almeida Prado, Cantídio de Moura Campos e do grupo da Klaxon (DUARTE, 1977), Moraes, segundo afirmações suas, em entrevistas e textos memorialísticos, foi o autor da parte do projeto que trata da Divisão de Bibliotecas. A linguagem objetiva e as marcas de preocupação com a memória em ação

\footnotetext{
${ }^{43}$ Armando Salles de Oliveira era descendente de uma família de comerciantes de Jacareí ligada também aos investimentos na construção de ferrovias. Órfão precoce de pai, assume o ramo deste e atua na construção de ferrovias, com sucesso. Nos anos 1920, expande seus investimentos em outros ramos da infraestrutura, como a geração de energia por usinas hidroelétricas e o fornecimento de energia por meio da rede de cabos; atua em outras frentes, ligando-se por laços matrimoniais ao clã dos Mesquita, proprietários do jornal O Estado de S. Paulo, e viaja à Europa no fito de buscar alternativas tecnológicas para os desafios estruturais do rápido crescimento paulista. Membro do Partido Democrático e da decorrente união entre este e o PRP, formando a Frente Única Paulista, assume o papel de garantir o abastecimento da cidade durante a Revolta Constitucionalista de 1932. Após o fim das hostilidades entre São Paulo e o governo federal, atua na formação da Chapa Única para concorrer aos mandatos para deputados constituintes. O sucesso da Chapa Única, que elegeu 17 dos 22 representantes de São Paulo no Legislativo federal, somado ao seu trânsito por todos os grupos políticos paulistas, o posicionou em situação privilegiada para pleitear a indicação ao cargo de interventor federal - o substituto do governador de Estado, nomeado por ordem do Presidente da República - no Estado de São Paulo, fato que afinal ocorreu em 17 de agosto de 1933. O sucesso de sua administração o gabarita para uma vitória na eleição indireta realizada em 1935 , a partir da qual passa a governar por mandato democrático até 29 de dezembro, quando renuncia ao cargo para se dedicar à candidatura para presidente da República. As eleições foram canceladas, como se sabe, pelo Golpe de 10 de novembro de 1937.

${ }^{44}$ Sobrinho de uma das figuras mais emblemáticas da política paulista entre o final do Império e o início da República, o Conselheiro Antônio Prado, que terminou sua carreira política engrossando o coro dos fundadores do Partido Democrático. Fábio era engenheiro de formação e se dedicou às indústrias da família até ingressar na política no cargo de vereador da capital, sendo alçado à condição de chefe do executivo municipal em 1934.
} 
evidenciam, se não a autoria, a grande participação e influência de Moraes na redação dessa parte do projeto que se refere à Divisão de Bibliotecas.

O Departamento de Cultura foi organizado em cinco divisões, o que segundo Moraes favorecia a gestão do projeto conforme conhecimento e interesse de cada um dos envolvidos. A Divisão de Expansão Cultural ficou a cargo de Mário de Andrade, a de Educação e Recreio, de Nicanor Miranda, a de Documentação Histórica e Social ficou sob a responsabilidade de Sérgio Milliet e a de Bibliotecas, de Rubens Borba de Moraes; por último, a de Turismo e Divertimentos, não chegou a ser implementada.

O objetivo do grupo, embora não declarado naquele momento, era fazer "política cultural" (MORAES, 1983). Reordenar, redefinir, reestruturar a atividade cultural estava dentro do escopo daqueles que buscavam se encontrar num país em pleno desenvolvimento urbanoindustrial e questionamento identitário. A cultura era parte constitutiva da vida moderna, ganhara centralidade e não era mais simples atividade subsidiária, "diversão" no espectro diversificado da vida social.

Mário de Andrade, que constantemente se declarava um homem feliz em seu sossego, vibrava a cada conquista rumo ao desenvolvimento das ideias do futuro Instituto. Todavia, segundo Duarte (1977), não se via como candidato do "disputadíssimo" cargo de chefe da Expansão Cultural. A fala de Paulo Duarte parece indicar que a divisão da Expansão cultural e a da Documentação Histórica e Social eram as mais importantes do Departamento:

Havia pelo menos cinquenta candidatos que se julgavam excelentes para dirigir a Expansão Cultural, ou para dar conta da Documentação Histórica e Social, todos aqueles postos para os quais campeávamos um dirigente capaz, sem encontrar! (DUARTE, 1977, p. 52)

Não se sabe ao certo quais as características almejadas para tais cargos; o que se vê por meio de cartas e jornais da época é que os idealizadores buscavam intelectuais que se dispusessem a colocar seu conhecimento em ação.

Nesses termos, é difícil imaginar que os idealizadores encontrassem alguém fora do seu círculo que pudesse responder às demandas pensadas por eles mesmos. Encontraram-no na figura de Moraes, membro do grupo que preenchia a contento o perfil demandado então como bibliotecário $^{45}$. Além de sua bibliofilia, que o próprio RBM e seus amigos de Klaxon,

\footnotetext{
${ }^{45}$ À época, era considerado bibliotecário o ser letrado ou erudito, amante e conhecedor dos livros que se dedicava à preservação da memória social impressa, em bibliotecas particulares ou públicas, e que colocava à disposição das instituições de memória seu conhecimento empírico, literário e histórico. A identidade definia-se pelo seu vínculo mantido com o conhecimento registrado nos livros e dos quais o bibliotecário seria o guardião. Foi só
} 
consideravam compor o cerne de sua identidade; Moraes juntava ao gosto clássico pelo universo letrado, a vocação "moderna" por sua difusão, pela circulação das ideias, como forma de desenvolvimento civilizatório. Da mesma forma, RBM era um crítico da "desordem" dos livros e sabia da importância de sua ordenação para a recuperação pelos leitores, preocupação que alavancava a nova biblioteconomia. Em outras palavras, RBM possuía um perfil que conjugava erudição e ação, amor aos livros e clareza quanto à importância de sua circulação social. Para tanto, precisavam ser devidamente organizados, a partir de procedimentos técnicos especializados que permitissem a públicos diversos recuperá-los. Assim, a Biblioteconomia moderna encontrava no modernista Moraes figura síntese que necessitava para dar início a processo que o extrapolava, mas que ganharia força e densidade no país, com sua designação como Diretor da Divisão de Bibliotecas do Departamento de Cultura.

Em carta enviada por RBM a Mário de Andrade por ocasião de recebimento da primeira edição de Klaxon, lançada em maio de 1922, Moraes afirma:

Se eu te digo tudo isso às pressas numa linguagem horrível, meu caro Mário, é porque não sou nem poeta, nem escritor, nem crítico, nem diplomata, nem fazendeiro, nem jardineiro, nem pescador, mas simplesmente um pobre diabo que ama os livros. Gente mui sabia em grego e português nos chama de um nome feio: bibliófilos. Se eu te digo tudo isso é porque és um velho amigo e aos velhos amigos unicamente, diz-se a verdade. Não pense sobretudo que é crítica, não sou crítico já disse, sou Klaxista e quero o êxito de Klaxon; que Deus vos guarde. (MORAES, 1922, p. 2) ${ }^{46}$

Para RBM, a bibliofilia servia como mapa de lugares desconhecidos. A biblioteca seria, assim, ponto de chegada e ao mesmo tempo de partida, de possibilidades de construção de novas identidades. Foi o espaço que ele procurou para se conectar à cultura do Brasil, ao retornar, mas que não ofereceu respostas às suas expectativas. Por isso, talvez seja possível observar que tais concepções gerarão frustrações com acervos e dinâmicas das bibliotecas na cidade de São Paulo dos anos 1920 e que, segundo ele, estavam defasados.

A compreensão de que as bibliotecas brasileiras estavam defasadas, tanto no âmbito do acervo quanto de sua organização e dinâmicas em geral, era compartilhada por bibliotecários

\footnotetext{
posteriormente que o bibliotecário passou a se definir como especialista, o que levará à construção identitária distinta, de ordem técnica e especializada, ligada ao domínio de procedimentos de organização e gestão documental. A identidade desloca-se dos territórios dos afetos para situar-se nos da racionalidade, muitas vezes reduzida à racionalidade instrumental.

${ }^{46}$ Carta enviada por RBM a Mário de Andrade [possivelmente do dia 29 de maio de 1922] por ocasião de recebimento da primeira edição de Klaxon lançada em maio do mesmo ano. O documento pode ser consultado no Arquivo do Instituto de Estudos Brasileiros, Fundo Mário de Andrade (MA-C-CPL-5221).
} 
pioneiros, identificados com a renovação dessas instituições no Brasil. Exemplo é Menegale ${ }^{47}$ em Minas Gerais, e Sérgio Milliet ${ }^{48}$ participante do grupo de modernistas de São Paulo. Todos previam no âmbito das bibliotecas a criação de um campo bibliotecário que envolvesse a profissionalização do bibliotecário, a criação de um corpo de profissionais e de bibliotecas atuantes nos projetos de modernização do país.

Moraes reitera em suas memórias que o seu lugar era a biblioteca. Paulo Duarte salienta: "O Rubens, pelo gosto de ir para a biblioteca, abandonara, na Recebedoria de Rendas, um lugar onde ganhava mais" (DUARTE, 1977, p. 52). A fala de Paulo Duarte reforça a ideia de que Moraes tinha uma relação afetiva com as bibliotecas, a ponto de dispensar o provimento maior de um funcionário da receita estadual para se dedicar a um projeto de bibliotecas públicas. A reestruturação prevista para a Biblioteca Municipal ditava que seu chefe morasse dentro dela, embora isso não viesse a ocorrer, pois a intervenção de Prestes Maia no projeto de Biblioteconomia almejado pelos modernistas alterou inclusive a estrutura física da Biblioteca, retirando a torre de residência do diretor. A justificativa apresentada para essa supressão era de que a cidade de São Paulo não comportaria uma biblioteca com as dimensões projetadas por Moraes e o arquiteto Jacques Pilon.

A ideia de construir a residência dentro da biblioteca ilustra bem o espírito bibliotecário que RBM havia incorporado: amor e dedicação pessoal aos livros, à cultura letrada e o interesse de compartilhamento público desse amor, no caso específico, representado pela dedicação aos projetos da Divisão de Bibliotecas do Departamento de Cultura. A vida pessoal e a pública se fundem, portanto, caracterizando um modelo de gestor cultural que perdurará na vida

\footnotetext{
${ }^{47} \mathrm{Em}$ 1932, Menegale redigiu um relatório da Biblioteca Pública de Belo Horizonte, texto em que manifestava os problemas e os projetos para a biblioteca da cidade. Dele resultou um livro, intitulado O que é e o que deve ser a biblioteca pública. Moraes teve conhecimento dessa obra e procurou Menegale como interlocutor, enviando emissários da Biblioteca Municipal de São Paulo para lá. Posteriormente, quando da criação da Escola de Biblioteconomia, por Rubens Borba de Moraes, em São Paulo, uma das matriculadas viria a ser Etelvina de Lima, funcionária da biblioteca belo-horizontina.

${ }^{48}$ Milliet, em 1931, tinha sido escolhido para o cargo de Diretor-técnico na Biblioteca da Faculdade de Direito com a missão de compor o catálogo decimal da Biblioteca. Anos antes de Milliet assumir o cargo de bibliotecário na faculdade, Spencer Vampré (1888-1964), diretor da Faculdade de Direito, já defendia a adoção da classificação decimal de Dewey, como demonstrado por um discurso preparado por Spencer Vampré em 1925, em comemoração ao centenário da faculdade. A esse respeito, cf.: VAMPRÉ, S. O centenário da Fundação da Primeira Bibliotheca Pública de S. Paulo. O Estado de São Paulo, ano 51, n. 16.862, p. 2, 25 abr. 1925. Disponível em: https://acervo.estadao.com.br/pagina/\#!/19250425-16862-nac-0001-999-1-not. Acesso em: 20 maio 2021. A ideia defendida por Vampré visava manter o acervo organizado por localização fixa e alterar apenas os registros bibliográficos para a classificação decimal, o que foi concretizado em 1931, por Milliet. Milliet, antes de ingressar como bibliotecário na Faculdade de Direito, por meio de carta, tinha solicitado intercessão de Mário de Andrade junto a Paulo Prado para trabalhar no consulado do Brasil na Europa; como não foi atendido, em 1931, começou a trabalhar na Biblioteca do Largo São Francisco. A carta pode ser consultada no Arquivo do Instituto de Estudos Brasileiros, Fundo Mário de Andrade (MA-C-CPL4911).
} 
sociocultural brasileira e que transitará entre a ética da convicção e a ética da responsabilidade (WEBER, 1982). 


\section{UM BIBLIOTECÁRIO EM AÇÃO}

Neste capítulo, apresentaremos o projeto da Divisão de Bibliotecas em diálogo com a bibliografia da história social dos livros, das bibliotecas, de bibliotecários e da leitura, a fim de extrair elementos que corroboram com a constituição da Biblioteconomia no Brasil, enquanto campo inserido em projeto político-cultural e, ao mesmo tempo, em tensão com a realidade viva do país, herdeiro de marcas que continuaram fortes também no período pós-colonial, apesar de tentativas de modernização sob diferentes regimes e em diferentes períodos. $\mathrm{O}$ interesse e a articulação de múltiplas disciplinas por esses objetos nos ajudam a identificar quais foram os debates que movimentaram a Biblioteconomia em seu período inicial, entre nós, quais forças entraram em disputa, quais eram os meios associativos de discussão, dentre outros importantes aspectos implicados na construção do campo. Trataremos da ação de Rubens Borba de Moraes no universo das bibliotecas, no bojo de inquietações que mobilizavam pessoas ligadas à educação e à cultura, como, por exemplo, setores da elite intelectual e vários atores ligados à cadeia do livro e da leitura - entendidos aqui como autores, editores, tipógrafos, bibliotecários, professores, livreiros, dentre outros (BUTLEN, 2008).

Moraes vinha de uma tradição em que cabia ao erudito, ao homem das letras o cargo de bibliotecário, entendido como conservados e gestor dos acervos (conservateur). Sua função era o cuidado e a guarda, resumindo-se do ponto de vista político-cultural e funcional a reproduzir os modos de manutenção e conservação já estabelecidos pela tradição. Eram eficientes aqueles que conseguissem seguir a ordem previamente estabelecida, assegurando a aplicação das técnicas de organização e preservação de coleções, a serem utilizadas por pequenos grupos das elites dirigentes, com o controle atento, tanto dos objetos quanto de modos de ler os documentos. Os desafios do bibliotecário se limitavam a execução de tarefas cotidianas de controle, centradas, sobretudo, na coleção, condição que o tornava o bibliotecário; com frequência um executor de palavras de ordem dos poderes estabelecidos (POIRIER, 2001).

RBM e os circuitos intelectuais de que fazia parte inaugura, assim, com a perspectiva modernista, uma concepção de biblioteca e de bibliotecário distinta, que tinha na circulação e no uso, dos objetos culturais seu ponto de inflexão, seguindo olhar que reitera discursos e práticas que vinham ocorrendo em nível mundial. Biblioteca e bibliotecário inscreviam-se em processos de mudanças políticas, econômicas e sociais, próprios da modernidade, e ser bibliotecário em tal contexto, especialmente em países de industrialização e democratização tardias, com o Brasil, significava assumir outros saberes, outros fazeres, outra identidade. Para Poirier (2001), que realizou um estudo comparativo entre o que chama de bibliotecário gestor 
e bibliotecário líder, foram as mudanças tecnológicas (nos meios de produção, organização e disseminação de informações), sociais e econômicas que estabeleceram uma nova conjuntura, atualmente muito "pouco previsível”, que estabeleceram novos desafios aos bibliotecários, a começar pela reflexão do que é ser bibliotecário no século XX.

É com esse espírito moderno, assumido conscientemente como projeto histórico e cultural que Moraes se revela emblemático de uma ruptura de paradigma cultural e que resultou na institucionalização do campo da Biblioteconomia brasileira, no transcorrer do século XX. Ao estudar a história das bibliotecas e sua relação com a elite cultural, Moraes se interessou pelos meandros da Biblioteconomia, no mundo europeu e norte-americano, a fim de propor mudanças estruturais na fratura social que separava a sociedade da cultura letrada, no Brasil. (Moraes, 1983). Entre estratégias “de convicção”, procedentes de foro íntimo e de história familiar e estratégias "de responsabilidade", assumira as tensões daí resultantes e que, marcam até os tempos atuais, sob diferentes formas, os destinos da área e de tudo o que a ela se refere. Talvez se pudesse dizer, uma Biblioteconomia com o "jeitinho" brasileiro, apesar da marca não ter sido exclusividade nossa. Mas, provavelmente, sua permanência e assimilação como traço cultural.

Tal quadro nos leva a considerar as ações de RBM no interior de uma rede de iniciativas e agentes que o sustentaram e, ao mesmo tempo, se sustentaram, inspirando-se nas ações levadas a cabo pelo Departamento de Cultura. Então, é desse conjunto de mobilizações sociais, de maior ou menor fôlego, mais ou menos renovadoras, que veremos se constituir um quadro de instituições, de profissionais, de legislações, de publicações e de referências que acabarão por constituir o campo e seus marcadores materiais e imateriais.

Nesse sentido, abrangeremos as inquietações que levaram às primeiras manifestações de RBM com vistas a conceber uma trama bibliotecária que sustentasse o projeto de democratização cultural idealizado pelos modernistas paulistas, como parte do projeto de construção da identidade nacional. Analisaremos desdobramentos de ações idealizadas e realizadas, a partir dos anos 1920, e do clima "modernista", mas, sobretudo, a partir dos anos 1930, com a criação de situações e condições que permitiram iniciativas indispensáveis à constituição da Biblioteconomia brasileira como campo de práticas e saberes socioculturais e não apenas manifestação pontual, localizada e encerrada em si mesma. Adicionalmente faremos referência aos projetos em torno do sistema de bibliotecas públicas, incluído nos projetos de RBM para a cidade de São Paulo e que envolvia unidades voltadas ao público infantil, aos operários e a estudiosos. Destacado, dada a importância que adquiriu, deixa-se para o próximo 
capítulo a análise sobre a atuação e repercussão da Escola de Biblioteconomia em São Paulo e que teve RBM como mentor e seu diretor.

Este movimento no tempo nos permitirá ver que os anos 1930 foram um período fértil para a institucionalização da Biblioteconomia brasileira, graças à capilaridade e à resistência de projetos de sociedade sustentados por bibliotecários engajados em políticas culturais locais ou nacionais, afinados com ideais de modernização, muitas vezes democratizantes em suas finalidades declaradas, mas nem sempre nas práticas e nos meios adotados.

\subsection{Primeiras manifestações}

A história de RBM com os problemas bibliotecários nacionais é resultado, como mencionamos antes, de uma preocupação expressa décadas antes, logo que retornou da Europa para o Brasil (1919). Inicialmente, instalou-se na fazenda de sua família, onde havia uma biblioteca da qual, segundo ele, se apropriou. Neste período, foi a São Paulo, para visitar o velho amigo da infância e de sua família, Mário de Andrade, e para ir às Bibliotecas na cidade. Segundo Moraes, essas ações tinham como objetivo declarado conhecer a cultura brasileira por meio de contato com o amigo e de registros históricos e literários guardados nos livros e nas bibliotecas.

Seu contato inicial com as bibliotecas estadual e municipal de São Paulo provocou indignação:

\footnotetext{
Não tinha verba para comprar livros, para comprar nada. Aquilo acabou ficando um depósito de livros. Nomearam para lá um diretor que fez alguma coisa. Depois veio outro, que não pôde fazer nada. Tinha uma frequência de umas dez ou quinze pessoas por dia [...] Era muito rica em literatura, péssima em ciência e assuntos afins, mas essas coisas não eram estudadas porque não existiam naquela época em São Paulo. O acervo da literatura parava em Machado de Assis. Os modernos não se compravam, era como se não existissem. (MORAES, 1978, p. 1)
}

O contato com as bibliotecas paulistanas, inicialmente como leitor, chamou a atenção de RBM para a ausência de política de desenvolvimento de coleções, para a falta de organização dos acervos; situação que resultava na dificuldade de acesso do público aos documentos. Não havia catálogos previamente elaborados pela instituição, nem instrumentos de recuperação de documentos e de informações que não fosse a disponibilidade e a boa vontade do atendente. RBM critica já nesse período, a adoção, pela gestão da instituição, da concepção de biblioteca como "depósito de livros", o que implica em dizer que ela estaria pautada, quando muito, pela 
guarda patrimonial, objetivo tampouco alcançado pelas instituições paulistanas, a se julgar o estado físico do acervo relatado por Moraes.

As críticas de Moraes ao "depósito", não significa, todavia, falta de reconhecimento da importância da biblioteca como instituição de preservação da herança cultural. Para RBM tal herança devia estar não somente preservada, como também organizada adequadamente, possibilitando a recuperação dos "tesouros" aí guardados. Tratava-se, portanto, de mudar a compreensão sobre o lugar da biblioteca na sociedade, dotando-a de condições de acesso ao público, ou seja, em instrumento de disponibilização da memória social, condição de sua recriação, em termos da contemporaneidade dos leitores. Referindo-se à visão reduzida do papel da biblioteca na sociedade, Moraes registra que tal limitação implicou em improviso, na aceitação de prédios residenciais usados como biblioteca, sem as devidas adequações, impossibilitando, por exemplo, a ampliação dos acervos e restringindo o acesso da população a eles (MORAES, 1978).

A indignação com o estado das únicas bibliotecas disponíveis quando chegou à capital paulista, segundo Moraes, está na origem de seu desejo de organizar bibliotecas "decentes", algo que já lhe ocorria, portanto, antes de entrar para o Departamento de Cultura. A precariedade do que observava teria suscitado a ideia de criar, na cidade, uma biblioteca acessível e com acervo abrangente e atualizado. O termo "atualização" aparece em suas falas, notadamente, como sinônimo de resposta a anseios de estudiosos, como ele, ávidos por conhecimento e com imensas dificuldades para acessá-lo. Da mesma forma, Moraes utiliza o adjetivo "desatualizado" para designar a falta de renovação e ampliação dos acervos, assim como a abrangência cultural limitada que, segundo ele, exibiam.

As críticas de Moraes não eram exclusivas. Outros frequentadores das bibliotecas paulistanas apontavam seus desconfortos com o serviço oferecido. Como interessado, ele provavelmente acompanhou as ações empreendidas pela Câmara Municipal de São Paulo, entre os meses de janeiro e fevereiro de 1926, com o objetivo de modificar o quadro apresentado; sem muito sucesso, todavia, já que se resumiu logo mais que a transferência de lugar da biblioteca do município, acrescentando-lhe o epíteto de "pública". Uma breve narrativa deste episódio do cotidiano do Legislativo paulistano permitirá enxergar, mais adiante e por contraste, o que foi realizado pelo grupo liderado por Mário de Andrade e que teve Rubens Borba de Moraes, como participante. Todavia, e enquanto eles não entram efetivamente no campo da biblioteconomia, vejamos o que (não) foi feito.

Em 12 de janeiro de 1926, Raphael Archanjo Gurgel, vereador presidente da Câmara Municipal em fim de mandato fez aprovar, nos Anais da Câmara, sem registro de discussões, 
um ato administrativo contendo um novo regulamento para a Biblioteca Municipal, definindo quais seriam as seções da biblioteca ${ }^{49}$ e qual o pessoal a ser empregado. ${ }^{50}$

O regulamento fixava as inúmeras atribuições do diretor da Biblioteca Municipal, dentre elas, destacadas no artigo $10^{\circ}$, as questões ligadas à gestão dos funcionários que parecem ter importância maior que as da constituição e preservação das coleções, embora estas também ali figurassem, incluídas no artigo $5^{\circ}$. Assim, primeiramente, cabia ao diretor informar ao presidente da Câmara sobre a promoção de funcionários ou sanção, motivada por absenteísmo ou comportamento desrespeitoso; cabe a ele justificar até o máximo de oito faltas por mês para os funcionários e, feito o devido controle do corpo funcional, cabia-lhe, também, "velar pela conservação dos livros e mais objetos, proceder à discriminação dos que devem pertencer a cada uma das seções e promover as aquisições que julgar convenientes".

Caberia ao diretor da biblioteca também providenciar ações com as duplicatas, que poderiam ser permutadas por outras obras de interesse ou simplesmente doadas sem contrapartida; expulsar os consulentes que se portarem de forma inconveniente na Biblioteca, publicar os Anais da Biblioteca Pública Municipal de São Paulo e promover, quando possível, um curso prático para os funcionários.

Há outros itens do Regulamento que visam a restringir a circulação de pessoas nas dependências da biblioteca, com recomendações expressas para que os funcionários buscassem evitar transitar pela sala de consulentes e que as visitas a funcionários não acessassem nem esta sala e nem a sala de depósito, permanecendo no vestíbulo de entrada. Consulentes não poderiam em nenhuma hipótese acessar a área do acervo.

O Regulamento é bastante detalhista na gestão dos recursos da biblioteca e nas receitas que ela poderia gerar para os cofres públicos. Estabelece o preço e as condições para o fornecimento de cópias, para o uso da sala de conferências - que poderia ser alugada, desde que não servisse a objetivos políticos e religiosos - e para o provimento das nomeações, geralmente a critério do Presidente da Câmara e do seu diretor-chefe.

O $92^{\circ}$ artigo (o Regulamento possui ao todo 96) sugere a criação de salas de leitura em bairros populares, cujos acervos seriam constituídos por "manuais de artes e ofícios, livros de viagem, história e literatura acessíveis ao público" (artigo 92º ). O novo regulamento não se

\footnotetext{
${ }^{49}$ Conforme o artigo $5^{\circ}$ do regimento, a $1^{\text {a }}$ seção abrangia livros, folhetos, avulsos tipográficos e músicas impressas; a $2^{\mathrm{a}}$ seção incluía as publicações periódicas, com exceção daquelas compostas pelas normas jurídicas ou com providências administrativas; a $3^{\mathrm{a}}$ seção incluiria a iconografia e a cartografia; a $4^{\mathrm{a}}$ seção, os elementos de paleografia e diplomáticos.

${ }^{50}$ Os cargos estavam assim distribuídos: 3 cargos de direção, 5 de encarregados, 8 funcionários administrativos e 10 funcionários para serviços manuais.
} 
preocupa em definir o que considera "acessível", nem dá detalhes sobre como deveriam funcionar estas salas, ou mesmo quando elas deveriam ser abertas.

O Regulamento de 1926 foi uma das últimas realizações de um parlamentar no ocaso de sua breve carreira, sem grandes mobilizações para sua aprovação. Afirma um conceito de bibliotecário como gestor público que, enquanto tal, deve estar preocupado com o controle de funcionários e consulentes, dos acervos e do balanço entre as receitas e despesas da "repartição". Era prioridade, fixada em documento legal, informar seu superior imediato - o Presidente da Câmara - sobre as medidas punitivas a serem tomadas, bem como sobre promoções em serviço.

As alternativas ao cotidiano morno da repartição, previstas pelo regulamento não surtem grandes efeitos. A publicação dos Anais passa despercebida inclusive do público voltado para a cultura; não há evidências suficientes para afirmar que os cursos de "bibliotecosofia" (como são chamados no regulamento) tenham existido, nem as salas de leitura popular.

O Regulamento é concomitante à abertura de um novo prédio para a Biblioteca, que deixa de ocupar algumas salas contíguas à Câmara para um espaço arrendado pelo Legislativo, na Rua Sete de Abril, 37, no centro. O novo prédio era uma propriedade particular, adaptada para ser um lugar de transição do acervo, que ali deveria permanecer por cinco anos, mas prorrogáveis por mais cinco. Entretanto, o prédio definitivo da Biblioteca Pública Municipal só viria a ser inaugurado em 1942, com seis anos de atraso em relação ao que havia sido determinado em 1925.

Para organizar a mudança de localização do acervo foi nomeada uma equipe chefiada por Eurico de Góes ${ }^{51}$ e que continha, entre seus funcionários, Maria Leonor Voigtlander ${ }^{52}$. A inauguração do prédio improvisado, em 15 de janeiro de 1926, é emblemática: houve atraso na chegada de livros comprados para ingressar no acervo e em outros itens da biblioteca, que por isso teve o acesso do público impedido, mesmo em se tratando da sala de consulta (REIPERT, 1972). Este fato talvez explique a decisão da Câmara Municipal de cancelar a propaganda que seria feita na revista Ariel sobre a inauguração do novo prédio, em um dos raros casos na história política brasileira em que os representantes eleitos se recusam a fazer propaganda de seus feitos, mesmo os não realizados.

\footnotetext{
${ }^{51}$ Deputado estadual na Bahia (1921-1922), Eurico de Góes foi organizador e primeiro diretor da Biblioteca Municipal de São Paulo, deixando o cargo ao ser substituído por RBM.

${ }^{52}$ Como veremos logo adiante, Eurico de Góes será pivô de um gesto administrativo que servirá como "batismo de fogo" para a gestão Mário de Andrade junto ao Departamento de Cultura. Voigtlander terá discreta, mas decisiva, participação na configuração do Curso de Biblioteconomia da Divisão de Bibliotecas na década de 1940.
} 
Os breves acontecimentos de 1926, ligados à Biblioteca Pública Municipal, demonstram o descompasso entre as políticas de cultura e os acontecimentos na cidade. À guisa de ilustração do argumento, cinco dias após a malfadada inauguração, o primeiro exemplar de Terras Roxas e Outras Terras ganharia as ruas; no mês seguinte, no dia 24, seria oficialmente fundado o Partido Democrático, defecção do PRP, portador de esperanças de renovação das políticas públicas, inclusive com os temas pertinentes à cultura e pelo qual se mobilizara RBM e outros membros dos circuitos modernistas, como visto anteriormente.

Ao mesmo tempo em que parlamentares da Câmara Municipal aplicavam saídas ineficientes para temas bibliotecários, a repetir a tradição biblioteconômica estabelecida, por outro lado, registrava-se uma fervilhante atividade na cidade que se industrializava, crescia e modernizava (SEVCENKO, 2009): artistas articulando-se em projetos como as revistas literárias, membros de diferentes frações sociais, formavam novos grupos políticos; a cidade fervilhava, "não era moderna, mas não tinha já passado" na leitura indicada, de Sevcenko (2009). Os tempos acelerados de transformação na Pauliceia envolveram a percepção compartilhada por vários setores sociais sobre a necessidade de se pensar em novos espaços e novas funções para as bibliotecas da cidade. Mas é apenas com o Departamento de Cultura, em 1935, que as soluções apontadas passam a ser postas em prática, em meio evidentemente às tensões existentes no cenário paulistano, paulista e brasileiro.

A sintonia de Moraes com os problemas do ambiente em que vivia levou-o a gerar um dos incômodos devido à defasagem intelectual que observava no país em relação à Europa, imposta, sobretudo, pela falta de material bibliográfico atualizado. Segundo ele, nem mesmo questões que o tinham marcado no início de seu longo período europeu, tinham chegado ao país, anos depois, após seu retorno.

O Brasil, ainda incipiente no âmbito da editoração e ancorado em sua própria história, vivia, entretanto, um momento de opacidade e silêncio (DARNTON, 1988), tanto no âmbito da produção de livros quanto no da apropriação de seus conteúdos. A condição colonial deixou o país sem uma tradição editorial, diferentemente de locais como a Cidade do México ou Lima, no Peru, que puderam introduzir a impressão no país logo depois da conquista espanhola (DAVINSON, 1975; HALLEWELL, 2005) $)^{53}$.

\footnotetext{
53 Na América Portuguesa, a monarquia de Lisboa impediu o estabelecimento de tipografias; em decorrência, a igreja católica assumiu o papel de mediadora dos livros, contando com a atuação de padres que tinham acesso à cultura escrita e assim podiam interpretar textos sagrados ou profanos para a comunidade, evitando a difusão de livros que pudessem comprometer ideias entendidas pela Igreja como "perigosas". Tal fato significa dizer, também, que a oferta de livros dependia em grande medida do mercado editorial europeu, sobretudo português e francês (EL FAR, 2006), reduzindo a estreita oferta de livros a obras estrangeiras, traduzidas ou impressas fora do
} 
Para compreender melhor as desventuras de RBM face às condições encontradas em sua volta ao país é mister considerar a situação editorial nos países francófonos em que se formou. Ali, no início do século XX, já se impunha para certos circuitos socioculturais letrados, uma lógica de seletividade face à extensão do mercado editorial. Diante da impossibilidade de se conhecer tudo o que era produzido em larga escala o leitor deve desenvolver um processo de triagem, de qualificação dos livros que a ele se apresentam, como atitude intelectual determinante na era da explosão bibliográfica (CHARTIER, 1999). Da mesma forma, as bibliotecas, em vez do acúmulo irrefletido das obras, já enfrentam os dilemas da constituição, desenvolvimento e organização de seus acervos, compostos a partir da farta oferta do mercado editorial em língua francesa.

Se em alguns países europeus de vanguarda havia a preocupação com a explosão editorial, a proposta do então presidente interino da Câmara Municipal de São Paulo, Gurgel, em 1926, desconhecia essa realidade, embora São Paulo já fosse à época cidade símbolo de modernização cultural. Segundo Moraes (1981), não se pensava em critérios rigorosos, nem para composição, nem para atualização dos acervos; consequentemente, a busca de informações, o contato com a memória cultural, tema caro para ele, que via no uso do livro a razão de ser da guarda das coleções pela biblioteca pública, estava comprometido desde as origens.

Desse modo, o interesse em se vincular a projetos ligados às políticas das bibliotecas surgiu em Moraes como uma resposta à falta de perspectiva sobre o alargamento da função da biblioteca e, por conseguinte, redutora do papel do bibliotecário à função de almoxarife, conservador de um "depósito de livros", mais que uma biblioteca, mesmo se em moldes clássicos.

A resposta a tal interesse se concretiza no período da criação, em 1935, quando assume a Diretoria da Divisão de Bibliotecas do Departamento de Cultura, e onde poderá exercer sob diferentes formas sua preocupação com a memória bibliográfica, articulada à da sua circulação como ferramenta essencial de educação e de difusão cultural, funções a serem privilegiadas, segundo ele, nas ações em torno da biblioteca pública para adultos, da biblioteca infantil e das bibliotecas circulantes e ambulantes que foram então desenvolvidas.

Brasil. Nesse sentido, livros de literatura, sociologia e filosofia, assim como outros bens culturais como teatro, estavam restritos a parcelas reduzidas das elites letradas. 


\subsection{Preâmbulos da Divisão de Bibliotecas}

A implantação de um organismo da administração pública que se ocupasse da trama bibliotecária paulistana somente foi possível graças à reestruturação administrativa realizada por Fábio Prado, que viabilizou o Departamento de Cultura nos quadros da Prefeitura de São Paulo. Através do Ato $\mathrm{n}^{\circ}$ 861, de 30 de maio de 1935, ao instaurar o Departamento de Cultura, na seção III, artigos de 194 a 202, criava a Divisão de Bibliotecas que seria dirigida por Moraes. O projeto do Departamento foi apresentado inicialmente por Paulo Duarte a Armando Salles de Oliveira, interventor do Estado de São Paulo. Este indicou a proposta a Fábio Prado, por considerar que a Prefeitura estava em situação financeira mais favorável que o Estado naquele momento. A ideia seria acatada por Fábio Prado, em 1934, e levada a efeito em 1935, sob a liderança de Mário de Andrade. Sobre esta passagem, Moraes afirmou:

Foi aí que nasceu a ideia de criar um organismo estatal que incentivasse, em São Paulo, o estudo e a cultura. Não seria um departamento burocrático, mas seria um organismo vivo, ativo, que desse ao povo a possibilidade de cultura e procurasse resolver o problema da 'miséria cultural'. Não se tratava de alfabetizar para fabricar eleitores, mas de dar ao povo o acesso à cultura nas mesmas condições que a burguesia privilegiada. Não pretendíamos tratar da educação, da instrução popular, para isso já existia a secretaria de Educação com sua rede de escolas primárias, secundárias e faculdades. O que pretendíamos era criar um organismo que desse cultura ao povo, a cultura que não se aprendia nas escolas. $O$ organismo que idealizávamos não seria somente um centro de pesquisa do nosso meio, mas um instrumento capaz de agir socialmente. (MORAES, 2011, p. 217)

A leitura da fala de Moraes nos permite perceber que a preocupação com o que mais tarde seria chamado de "democratização cultural" estava no cerne do projeto do grupo que seria liderado do Mário de Andrade e que se ocuparia do Departamento então criado. No trecho, Moraes faz questão de diferenciar a concepção de formação cultural e de educação cultural, como categoria distinta de educação escolar, embora a ela articulada e em consonância com a posição do grupo dirigente do Departamento. Para este, a cultura era via diferenciada e indispensável à necessária elevação do país e do povo brasileiro à condição de nação civilizada. Não se tratava apenas de aprendizagem localizada especialmente no momento de escolarização, mas de vivência constante, corrente, ao longo da vida e traduzida em objetos culturais especiais e em processos a ele relacionados, cujo acesso é propiciado por instituições culturais como as bibliotecas. Nesse sentido, ainda que de forma complementar, o projeto e as estratégias do grupo fazem contraponto a posições de outros intelectuais do período, mais centrados, por 
exemplo, na "educação popular", feita muitas vezes à margem do Estado, mas da mesma forma entendida como elemento-chave nos projetos de superação dos modos "arcaicos" de viver, sobretudo de populações que migraram para as cidades ${ }^{54}$.

Em consonância com Mário de Andrade, Moraes reconhece, sem dúvida, a relevância da educação popular; mas refere-se também à sua limitação, enquanto tomada apenas como “instrução pública”, termo pelo qual era conhecida a educação básica nesse período. Era preciso, segundo ele, oferecer oportunidades de acesso à cultura, forma mais livre de amarras pedagógicas, fruto do contato direto e desinteressado do sujeito com leituras literárias, científicas, filosóficas, de diferentes naturezas.

Nessas circunstâncias, cultura era entendida aqui como conjunto de manifestações simbólicas produzidas pelas elites intelectuais locais e internacionais. Diferentemente, portanto, do fornecimento dos níveis básicos de instrução necessários para o domínio dos códigos escritos, mas não a participação efetiva nos circuitos de produção, distribuição e recepção da cultura escrita. A formação cultural, assim compreendida, ultrapassava a escolarização e era forma de cultivo do espírito superior a que somente "a burguesia privilegiada" tinha acesso, mas que necessitava se universalizar como recurso indispensável à superação do "atraso" e sua substituição pela modernização e o progresso.

Apesar das diferenças, o lema de "atraso versus civilização" perpassa variadas posições do período que professam em comum a crença na Educação e na Cultura como categorias determinantes à construção de condições geradoras do progresso da Nação e da brasilidade que deve singularizá-la e distingui-la.

Estava em pauta, portanto, um projeto político-cultural que pretendia, em movimento constante e ascendente, a partir do Estado, irradiar-se e tomar o país, modernizando-o, livrandoo da condição de pauperização material e imaterial em que se achava mergulhado, desde o período colonial:

\footnotetext{
${ }^{54}$ É com esse intuito que o livro com fins educacionais ganha força em programas de governos e as bibliotecas populares e públicas, por sua vez, ganham notoriedade. Desse modo, cidades que estavam ativamente em processo de organização social se envolveram em discussões sobre livros e bibliotecas, sobretudo em regiões do país que passavam por grandes mudanças no modelo agrário-exportador, como era o caso de São Paulo. Dadas as mudanças do papel da educação e da leitura na sociedade, cidades em processo crescente de urbanização experimentaram uma mudança na compreensão social dos livros: antes vistos como materialidade da memória, agora, além do valor histórico, passam a ter valor formativo do cidadão do futuro. É no bojo dessas discussões que bibliotecas ligadas a iniciativas e lógicas da "educação popular" também começam a ganhar existência na cidade que se industrializava e que via uma movimentação forte em relação à "aculturação letrada", como pode ser visto em: COSTA, A. L. J. da. Associativismo operário, educação e autonomia na formação da classe trabalhadora em São Paulo (1889-1930). Educ. Pesqui., São Paulo, v. 44, 2018. Disponível em http://www.scielo.br/scielo.php?script=sci_arttext\&pid=S1517-97022018000100472\&lng=pt\&nrm=iso. Acesso em: 03 maio 2021.
} 
Nós sabíamos que o Departamento era o germe do Instituto Brasileiro de Cultura. Primeiro, um Instituto Paulista, que Armando Salles no Governo já nos garantira. Para isso o projeto do Departamento do Patrimônio Histórico e Artístico de São Paulo, lá estava na Assembleia Legislativa, ladrado embora pela cachorrada solta do despeito e da incompreensão. Depois, com Armando Salles na Presidência da República, seria o Instituto Brasileiro, uma grande fundação libertada da influência política, com sede no Rio, inicialmente instalados, além do de S. Paulo, paradigma, outros núcleos em Minas, no Rio Grande do Sul, na Bahia, em Pernambuco e no Ceará. Tivéramos uma ideia genial que Armando Salles aprovou: os Institutos de Cultura assistiriam com assiduidade todas as grandes cidades, com a colaboração da Universidade, porque, não comportando evidentemente essas cidades uma Faculdade, teriam contato íntimo com esta, através de conferências, cursos, teatro, concertos, etc. (DUARTE, 1977, p. 55).

A Divisão de Bibliotecas estaria no cerne deste projeto $^{55}$ e, assim, elevaria a biblioteca e suas preocupações sociais ao âmago das propostas inovadoras de modernização do país. Era a primeira vez que bibliotecas e os processos de produção e difusão cultural se projetavam e se explicitavam não só em âmbito local, mas articulados às políticas públicas nacionais, porquanto não havia nada semelhante consolidado em âmbito municipal, estadual ou federal ${ }^{56}$. Segundo Mário de Andrade, “[...] o prefeito Fábio Prado deu todo o seu carinho para a organização do Departamento Municipal de Cultura, como uma tentativa de criar em nossa capital um corpo auxiliar da Universidade de São Paulo" (ANDRADE, 1936, p. 3).

A declaração de Mário de Andrade demonstra a importância que o prefeito Fábio Prado atribuía ao Departamento de Cultura; nesse sentido, o "corpo auxiliar" e "cultural" da USP era parte do projeto de uma elite paulista histórica que, associada a outros segmentos "modernos" do país, pretendia retomar o controle das agendas econômicas e culturais do país, por meio de quadros técnicos e intelectuais cuja qualificação os posicionasse em condição insuperável na discussão sobre os rumos das políticas públicas de um Estado Nacional em fase de ampliação.

Uma das primeiras ações de Mário de Andrade foi buscar a opinião e o apoio de Eurico de Góes para apresentar a Fábio Prado um projeto de organização das "bibliotecas populares". Na visão de Mário de Andrade, o artigo 92 do Regulamento de 1926 da Biblioteca Pública Municipal serviria de base legal para um projeto bastante mais ambicioso e detalhista no seu modo de funcionar e nos objetivos a serem alcançados.

\footnotetext{
${ }^{55}$ Segundo Duarte (1985) a Divisão de Bibliotecas junto com a Divisão de Expansão Cultural e a de Estudos Sociais foram as primeiras idealizações dos modernistas na concepção do Departamento de Cultura.

${ }^{56}$ No momento de criação do Departamento de Cultura, já estava em funcionamento o Ministério da Educação e Saúde (MES), um dos primeiros atos de seu Governo Provisório. No entanto, as políticas públicas ligadas às bibliotecas somente viriam a ser objeto do MES após a criação, em 1937, do Instituto Nacional do Livro (INL), dirigido no primeiro momento por Augusto Meyer, com quem Moraes trocou correspondências e também debateu sobre as concepções de biblioteca e políticas públicas de democratização cultural. Sobre estes debates trataremos no capítulo 4.
} 
A correspondência entre o recém-empossado Diretor do Departamento de Cultura e o longevo Diretor da Divisão de Bibliotecas, que no período da troca das missivas em 1936 já possuía dez anos no cargo, revela personalidades com abordagens e ânimos bastante distintos a respeito do projeto das chamadas bibliotecas populares. Mário de Andrade tinha pressa; encaminhou seu projeto para Góes no dia 7 de agosto e, menos de uma semana depois, no dia 13 , voltava a cobrar uma resposta.

O documento preservado revela a minúcia do texto apresentado por Mário de Andrade: sugeria que a biblioteca permanecesse aberta inclusive domingos e feriados, que durante os dias normais permanecesse aberta até o horário das 23 horas e que fosse constituída por duas salas de consulta, onde o consulente poderia encontrar amplo acervo de revistas, jornais e livros, cabendo no caso destes últimos a possibilidade de empréstimo a domicílio.

Até aqui, já se pode notar que o projeto de Mário de Andrade excedia consideravelmente o que, à época, eram as práticas bibliotecárias da cidade. Em sua compreensão, uma biblioteca se configurava como algo muito além da modesta "sala de leitura", proposta pelo Regulamento de 1926. Outras inovações são colocadas sem trechos do ofício enviado por Mário a Góes:

4 - A biblioteca terá uma seção destinada à correspondência popular, que será sempre feita dentro da biblioteca, auxiliada pelos funcionários desta quando este auxílio for pedido, e depositada na própria caixa de correio do edifício que se encarregará de encaminhá-la;

5 - A biblioteca terá uma seção bibliográfica, destinada a orientar o povo em suas leituras, aceitar-lhes as reclamações, providenciar sobre a falta de livros solicitados, e mesmo na medida do possível, responder a qualquer consulta de caráter instrutivo;

6 - A biblioteca terá uma seção de cultura, destinada a promover no edifício pequenos cursos de caráter vulgarizador, conferências isoladas, com auxílio ou não de cinematografia, rádio e disco; articulando-se para isso com a Rádioescola e a Discoteca Pública;

7 - A biblioteca terá um jornal mural, destinado às notícias nacionais e internacionais mais importantes do dia, como a expor artigos, poesias, desenhos, reclamações e quaisquer manifestações gráficas provindas do povo. (ANDRADE, 1935, p. 2)

O projeto de Mário de Andrade apresenta uma clara abertura para a participação da comunidade atendida pela biblioteca. Ela se pretende apresentar como uma via de mão dupla: a formação do acervo é inicialmente responsabilidade do bibliotecário, mas ele deve ouvir o que os usuários têm a dizer e justificar as ausências de livros que se fizerem pedidos em grande número. A biblioteca tem a responsabilidade de oferecer cursos de formação e o bibliotecário deve, quando solicitado, instruir o leitor quanto ao que ler; mas em troca também deve disponibilizar os espaços de participação da população. 
Para compreender o alcance dos projetos de Mário de Andrade é preciso mobilizar uma discussão do mundo da francofonia que gira em torno da diferença entre "democratização cultural” versus “democracia cultural” (ROMAINVILLE, 2014). André Malraux, em sua gestão à frente do equivalente francês ao "Ministério da Cultura""57, cria, nos anos 1950, diversos pressupostos básicos do que hoje consideramos política cultural, tais como a concepção da cultura como um direito social, do papel ativo do Estado em assegurar este direito e do protagonismo dos cidadãos comuns no exercício deste direito.

As inovações propostas por Malraux levaram ao surgimento de novos desafios e questões enfrentadas pelos atores desse ramo de atividade. Afinal, quais os limites entre o que pode ser considerado cultura e o que não pode ser envolvido neste rótulo? Quem define estes limites? A proposta de Malraux pressupunha a existência de cânones; ainda que houvesse uma discussão interminável se este ou aquele autor deveria pertencer ao cânone, a ideia de cânone em si mesma seria inquestionável.

Paradoxalmente, a hierarquização de produções culturais poderia encontrar abrigo em uma visão de mundo democrática. Era preciso preservar a "qualidade" da cultura oferecida à população; aproveitando-se dos múltiplos sentidos da palavra cultura, era como se fosse um gesto de respeito à população que o serviço cultural colhesse os melhores frutos do espírito para nutri-la.

É necessário evitar a confusão desses princípios básicos com a ideia de um academicismo, ou de um pedagogismo que pressupõe que os agentes do Estado devam direcionar as maneiras pelas quais a população usufrui da cultura. Tratava-se de projeto liberal, destinado a combater a reprodução da desigualdade perenizada pelo acesso desigual à cultura; uma bandeira que, segundo André Malraux, não deveria ser exclusiva da esquerda (ele próprio sendo identificado aos agrupamentos da direita gaullista).

Na década de 1960, enquanto outras nações como Bélgica e Canadá criam seus próprios Ministérios da Cultura no modelo proposto por Malraux, começam a surgir as primeiras fissuras do projeto. O movimento dos estudantes de Maio de 1968 privilegia leituras ${ }^{58}$ questionadoras do entendimento de que uma ação do Estado poderia assegurar a todos o mesmo acesso à “cultura erudita"; mais além do que isso, expõe-se a nu os mecanismos de mobilização de certos atributos culturais como formas de distinguir e hierarquizar indivíduos, preservando a falácia da "meritocracia".

\footnotetext{
${ }^{57}$ Ministère des Affaires culturelles, no original em francês.

${ }^{58}$ Este é um caso por excelência em que, não obstante o relativo distanciamento dos autores em relação ao movimento, sua obra adquire um sentido próprio e um uso político entre os estudantes.
} 
Assim como a "educação", a "cultura" deixa de ser vista por esse grupo crítico como o mecanismo de acesso para uma suposta e ilusória ascensão social assegurada a todos e de interesse de todos como projeto histórico e existencial.

Decorrente dessa percepção, questiona-se, portanto, os princípios básicos de ação estatal que pretende, no espírito típico da tecnocracia reinante em meados do século XX, "planejar" a cultura, "desenvolvê-la".

Fazendo eco às preocupações de maio de 1968, ganha fôlego a expressão "democracia cultural" que assume, como seus pressupostos, a quebra da barreira entre cultura erudita/popular, as ações culturais entendidas como um processo de participação democrática no qual o conjunto de indivíduos, envolvidos em trocas dinâmicas variadas, desenvolvem suas potencialidades, seus interesses, e em conjunto determinam o que deve ser apresentado ao coletivo $^{59}$

As discussões construídas no universo cultural francês entre as décadas de 1960 e 1980 parecem, em certa medida, serem antecipadas pela ação localizada de um grupo encabeçado por Mário de Andrade. Atinar ao que isso representa em termos de novidade não pode significar assumir um pensamento colonizado, através do qual consideramos que o melhor a se fazer nestes tristes tópicos é copiar o que a Europa pode nos oferecer de melhor - nesse caso, se tivéssemos sido capazes de nos avançarmos aos europeus em três décadas, poderíamos inclusive ter o orgulho de dizer que fomos mais europeus que os próprios europeus.

O intuito dessa digressão é bem distinto. Trata-se, mais precisamente, de perceber que, ainda que em momentos distintos, pela diversidade de circunstâncias históricas, muitas sociedades no século XX, enfrentaram as mesmas problemáticas ligadas ao tema das complexas relações entre cultura, valores democráticos de combate à desigualdade e o uso da riqueza apropriada pelo Estado para esse combate - ou para a reprodução dos abismos sociais.

No enfrentamento de uma questão que parece tão gigantesca, ações individuais adquirem sentidos mais amplos e a Biblioteconomia - e os bibliotecários - está na linha de frente desse feixe de conflitos sociais. Pensado dessa forma, adquire um especial sentido a resposta de Eurico Góes, enviada no mesmo dia da segunda cobrança de seu superior imediato e na qual demonstra sua falta de entusiasmo em relação ao projeto. Começa desculpando-se pela sinceridade "às vezes nem sempre [sic] bem compreendida por todos" e adotando a cortesia de elogiar o projeto em linhas gerais, para então começar com as críticas. Mário de Andrade

\footnotetext{
${ }^{59}$ Tais pressupostos passam a constar nos documentos oficiais produzidos por órgãos como a Unesco e a União Europeia, como a "Declaração sobre os direitos culturais”, da Unesco, assinada no México em 1982.
} 
propunha contratar um bibliotecário pelo valor de $800 \$ 000^{60}$, mas Góes pedia que ele acrescentasse a exigência de um diploma "ginasial normal ou, ao menos comercial"61 sem a necessidade de mostrar prévio conhecimento de "noções de biblioteconomia, que poderia obter, por sucintas aprendizagens, na sede ou matriz da Divisão de Bibliotecas” (GÓES, 1935, p. 2).

Esta seria apenas a primeira de uma série de críticas de Góes ao projeto e precisa ser lida em suas entrelinhas. No ambicioso plano de Mário de Andrade, chefiar a biblioteca exigiria erudição para guiar as leituras do público, disposição para trabalhar até tarde da noite, domingos e feriados e a capacidade de lidar com atendimento intensivo ao público, já que a biblioteca também serviria de espaço para manifestações artísticas espontâneas - no mural - ou programadas na seção de cultura, espaço também ofertado ao público no sentido de oferecer cursos, idealmente concebidos a partir das demandas manifestadas pela comunidade.

Por todas essas habilidades e disposições, Mário de Andrade sugeriu um salário elevado para os padrões da época, ao que tudo indica. Quando Góes rebate com a exigência de um diploma "ginasial" correspondente a uma etapa pré-universitária, tal posicionamento significa rebaixamento do estatuto desse profissional, posicionando-o em uma condição hierárquica inferior a que ele próprio ocupava: a de bibliotecário-diretor. É impossível, com as evidências de que dispomos, explicar as razões desse comportamento, mas é novamente um exemplo por oposição e contraste do que significaria, em termos de mudança de conceito, a criação da Escola de Biblioteconomia no ano seguinte à troca de missivas ora em análise.

Outras críticas de Góes ao projeto reforçam a leitura de que sua concepção de biblioteca era radicalmente divergente dos princípios que norteavam Mário de Andrade. Segundo aquele, o "Jornal Mural" poderia "perturbar, de alguma forma, a finalidade ou os propósitos diretos da biblioteca popular", a menos que fosse constantemente tutorado pelos funcionários da biblioteca.

Góes também sugere a substituição de uma sala de leitura aberta ao público por uma sala, à parte, dedicada à direção ou secretaria da biblioteca. Questiona igualmente o horário de

\footnotetext{
${ }^{60} \mathrm{O}$ documento não informa se o salário era anual ou mensal, mas assumimos o entendimento de que o mais provável é que fosse mensal, a partir de uma comparação com o que o próprio Mário de Andrade solicitaria dois anos depois, já para a Escola de Biblioteconomia da própria Divisão. Na ocasião, solicitou-se o pagamento mensal de 500\$000 para cada docente responsável por uma matéria do curso. Outra forma de comparar é informar que, no mesmo pedido de 1935, é incluído um contínuo com pagamento de $400 \$ 000$ e um servente por $250 \$ 000$.

${ }^{61} \mathrm{~A}$ linguagem de Góes é um pouco obscura por demonstrar certo atraso em relação à nomenclatura oficial utilizada na época. Com a Reforma Francisco Campos (Decreto $\mathrm{n}^{\circ}$ 19.890, de 18 de abril de 1931), o período de escolarização seguinte ao primário passou a se chamar "curso secundário" e teria duração mínima de 5 anos, podendo ser complementado por mais 2 anos caso incluísse a formação de docentes não universitários (o curso "normal"). O termo "ginasial", usado por Góes, não possuía mais base legal, mas ainda era bastante empregado na linguagem laica por força da Reforma Carlos Maximiliano, estabelecida pelo Decreto n ${ }^{\circ} 11530$, de 18 de março de 1915, e que cunhou a expressão "ginasial" para designar essa mesma fase escolar.
} 
funcionamento da repartição, que deveria ocorrer das 15 às 21 horas ou, "na pior das hipóteses", das 16 às 22 horas. Finaliza perguntando sobre os critérios de seleção do acervo a ser constituído e menciona que já havia vocalizado ao modernista quais deveriam ser eles, segundo sua visão. Nota que Mário de Andrade não havia escrito nada em resposta a essa conversa prévia.

Em resumo, o que Eurico de Góes propunha era um recuo de Mário de Andrade: menos tempo de abertura ao público, menos espaço, menos serviços e uma preocupação reduzida em relação à qualificação dos funcionários ${ }^{62}$. A resposta não viria a tardar, como será visto no próximo item, no qual analisaremos como os anseios de Mário de Andrade se objetivaram na Divisão de Bibliotecas, dirigida por Rubens Borba de Moraes, até 1942, com a saída de Góes. A Biblioteconomia emerge, assim, em cenário de disputas por posições no interior do aparelho de Estado e às quais os grupos a ela afeitos não eram - e não poderiam ser - alheios.

\subsection{Na Divisão de Bibliotecas: projetos e disputas}

A implantação da Divisão de Bibliotecas por Mário de Andrade culminou em mudanças estruturais na repartição que provocaram inúmeras críticas, como a publicada sob o título de "Comum de dois" em 05 de dezembro de 1935, na seção "Notas e comentários" do diário Correio Paulistano:

O sr. Eurico de Góis acaba de ser aposentado como diretor da Biblioteca Municipal, com 2:700\$000, sumariamente, por assim dizer. Teria o ilustre intelectual incorrido em qualquer falta grave? Quer-nos parecer que não. $\mathrm{O}$ próprio gesto do prefeito o diz. [...] Que é que há, então? Nada mais, nada menos do que a necessidade de colocar-se alguém. E esse alguém quem é? Baldada interrogação. De onde poderia vir o novo diretor da Biblioteca Pública Municipal se não do seio de Abraão que é a falange democrática? E foi o que se deu: o novo diretor é o Sr. Rubens Borba de Moraes. Fica, assim, o cargo de diretor da Biblioteca Pública Municipal, como tantos outros, a lembrar daquela designação gramatical de certos substantivos: -comuns de dois... (COMMUM, 1935, p. 5) $)^{63}$

A menção à "falange democrática" pode proporcionar uma chave de leitura para as razões que explicam a publicação da nota quando se leva em consideração que o periódico era tradicionalmente ligado ao Partido Republicano Paulista, do qual havia surgido, como dissidência, o Partido Democrático em 1926, com o qual Moraes se identificara desde seu

\footnotetext{
${ }^{62}$ Isso sem considerar que o silêncio de Mário de Andrade pode ser indício de um desacordo em relação aos critérios de formação de acervo propostos por Eurico de Góes.

${ }^{63}$ COMMUM de dois. Correio Paulistano. São Paulo, 05 dez. 1935. Notas e Comentários, p. 5. Disponível em: http://memoria.bn.br/docreader/DocReader.aspx?bib=090972_08\&pagfis=10216. Acesso em: 19 fev. 2021.
} 
início ${ }^{64}$. Ainda que o PD tenha sido extinto em $1934^{65}$, a menção à ideia de "democrático" pode ecoar disputas ainda recentes, sobretudo quando a ela se agrega a denominação "falange", palavra empregada tanto para designar um grupo de ação militar quanto para se referir a um grupo que age de forma ilícita.

Em ambos os casos, o texto parece indicar um uso irônico para a expressão, como uma forma de diminuir e desqualificar o grupo responsável pela indicação de Rubens Borba de Moraes, pela gritante contradição entre ser uma "falange" e ser "democrática". Denominar o grupo como o "seio de Abraão"66 e dizer que sua política de ocupação dos cargos públicos remete aos substantivos “comuns de dois gêneros" também pode ser compreendido como forma sutil de criticar o que, na visão do jornal, seria considerado um acúmulo indevido de cargos, com prejuízo de funcionários que não deveriam ser retirados de sua função. Se Moraes já assumira o cargo de Chefe da Divisão de Biblioteca, não haveria razão para exonerar o Diretor da Biblioteca Municipal e atribuir mais este cargo àquele.

Lida a contrapelo, essa passagem revela a importância conferida, no tempo de sua criação, aos cargos de chefia das Divisões do Departamento de Cultura e às aspirações das diversas tendências políticas a controlar - ou, na impossibilidade disso, a questionar - os critérios para nomeação. Sob o ponto de vista dos modernistas, houve um gesto estratégico de concentrar o controle sobre o projeto bibliotecário nas mãos de uma única pessoa, Rubens Borba de Moraes, um sinal de sua importância para as articulações da política cultural.

O que para o periódico era favorecimento político, representava para os modernistas o caminho de um "movimento a favor das bibliotecas e, sobretudo, um movimento que congregasse os bibliotecários que existiam naquela época" (MORAES, 1981, p. 6). Segundo Moraes, estava claro para o grupo que a Divisão de Bibliotecas seria entregue a ele que

\footnotetext{
${ }^{64}$ Para mais detalhes a esse respeito, regressar ao capítulo 2 da presente tese.

${ }^{65}$ Nessa data, o PD se fundiu com outra dissidência posterior do PRP (a "Ação Nacional Republicana") e a "Federação dos Voluntários" para formar o Partido Constitucionalista de São Paulo, comandado por Armando Salles de Oliveira e cuja linha política se definia pela tentativa de juntar as aspirações políticas da Revolução de 1930 e a Constitucionalista de 1932.

${ }^{66} \mathrm{~A}$ expressão "seio de Abraão" aparece em uma passagem do Novo Testamento e faz referência a um conceito do judaísmo corrente no primeiro século de nossa era. Como Abraão é considerado o patriarca do povo judeu, estar no "seio de Abraão" significa desfrutar de um lugar especial, privilegiado em relação aos comuns. Na parábola neotestamentária, esse sentido é invertido quando se narra que um rico comerciante e um mendigo teriam morrido no mesmo dia, porém apenas este último teria sido admitido ao "seio de Abraão", por ter agido de forma justa durante a vida, ao contrário do seu colega de sina. A se pautar por essa interpretação exegética, a ironia contida no texto do jornal seria a de que o grupo ligado ao Departamento de Cultura reservaria para si os melhores lugares na administração pública, mas o faria de forma injusta e deixando um rastro de iniquidades com funcionários estabelecidos na repartição.
} 
participou da concepção do projeto $^{67}$, pensado como uma trama para que pudesse ter sustentação e continuidade diante das oscilações políticas do período ${ }^{68}$.

Conforme discorremos no tópico 3.1, quando Rubens Borba de Moraes entrou para o órgão que ainda era denominado por "Departamento de Cultura e Recreação", o município de São Paulo tinha uma Biblioteca Pública Municipal ainda essencialmente herdeira de sua condição original de ter servido exclusivamente à Câmara, para a qual ainda respondia administrativamente. Sua situação, segundo Moraes (1983), "era lamentável”.

As condições das duas bibliotecas públicas da cidade fizeram com que Moraes levantasse várias críticas à forma como vinham sendo conduzidas as bibliotecas existentes na cidade de São Paulo. Vale lembrar que havia também uma Biblioteca Estadual, cuja condição, segundo Moraes, não era em nada superior à da Municipal. Defendia que a situação exigia, ao olhar do grupo modernista, a urgência de uma intermediação de alguém que entendesse dos livros e tivesse estreita relação com a cultura nacional.

Assim sendo, previram logo, no projeto da Divisão de Bibliotecas, a incorporação da Biblioteca Estadual pela Biblioteca Municipal, já que na instância do município poderiam fazer as mudanças almejadas no rol de ofertas de bibliotecas aos munícipes. Duarte (1977), assim como Moraes (1943), atribuía a situação das bibliotecas existentes, tanto a estadual quanto a municipal, ao fato de a coordenação destes espaços ser feita por burocratas que davam importância relativa a ela.

Sim, porque os nossos bibliotecários eram até então gente que entendia de tudo menos de biblioteca. Todo bacharel malogrado que não ia ser professor ia ser bibliotecário. Ou então, quando se tratava de amparar um desses velhos autodidatas brasileiros ou qualquer rebuscador de arquivos, quase sempre um bom sujeito, sem preparo e senso crítico, dava-se a ele a direção de uma biblioteca. Ora o que acontecia era que, no primeiro caso, esses institutos ficavam com um diretor para o qual só tinha importância ou a parte de manuscritos ou a parte literária ou a parte de livros antigos, ou o comodismo do cargo, conforme inclinação do velho medalhão. (DUARTE, 1977, p. 73)

Ao se reportar aos antigos bibliotecários como "velhos medalhões", Paulo Duarte aponta críticas aos bibliotecários "burocratas" que viam as bibliotecas apenas sob o "comodismo do cargo". Como visto no item anterior, as observações de Eurico de Góes sobre

\footnotetext{
${ }^{67}$ Paulo Duarte afirma que desde o princípio do projeto as bibliotecas seriam de responsabilidade de Moraes, ainda assim, caso Mário de Andrade falhasse na direção do Departamento, Rubens Borba de Moraes era um dos cotados para substituí-lo (DUARTE, 1977, p. 59).

${ }^{68}$ Como veremos no capítulo 3, o plano de bibliotecas envolveu a criação de leis no âmbito municipal e estadual, fazendo com que a trama bibliotecária se sustentasse em suas ramificações de recrutamento de multiplicadores e construção do arcabouço legal.
} 
os critérios de contratação de um novo bibliotecário parecem confirmar a leitura de Paulo Duarte. Para os modernistas paulistas, o plano de bibliotecas só iria avançar se fosse implementado sob uma premissa diferente daquela que vinha sendo empregada, estritamente ligado à conservação. Para isso, vislumbravam para o cargo o jovem modernista Borba de Moraes, que ficaria responsável por reunir na política cultural jovens engajados e esperançosos no futuro do país e, ao mesmo tempo, abertos para conhecer o que já se havia feito ${ }^{69}$. A fim de melhor compreender o que foi e o que significou o projeto da Divisão de Bibliotecas, iremos, nas próximas páginas, analisar o projeto que pautou as ações de Rubens Borba de Moraes à frente da Divisão.

\subsection{O projeto}

Ao recorrermos ao Projeto do Departamento de Cultura ${ }^{70}$ observamos que a primeira menção à Divisão de Bibliotecas ocorre logo no artigo $4^{\circ}$, no qual são descritas suas partes componentes:

1. Biblioteca Pública Municipal;

2. Bibliotecas Populares;

3. Bibliotecas Infantis;

4. Bibliotecas Circulantes e

5. Bibliotecas de Parques.

Rubens Borba de Moraes, na condição de Chefe de Divisão, respondia diretamente pela Biblioteca Pública Municipal, pelas bibliotecas populares, circulantes e de parques. A primeira já estava historicamente estabelecida na cidade, mas foi com Rubens Borba de Moraes que seu prédio atual foi construído, conforme será comentado algumas linhas a seguir. O projeto inicial de uma dezena de bibliotecas populares, concebidas por Mário de Andrade e Moraes para serem implantadas nos bairros operários da capital, foi apenas parcialmente realizado, com a

\footnotetext{
${ }^{69}$ Mocidade, moços; eram assim chamados os jovens intelectuais que atuavam na estrutura política com ideias progressistas (MATOS, 1933, p. 6).

${ }^{70}$ Ao longo da pesquisa tivemos acesso a diferentes versões do projeto do Departamento de Cultura, ora identificado como Anteprojeto, ora como regulamento, e ainda como Projeto. Foi possível verificar que partes do documento que analisamos neste texto foram posteriormente transformadas como "Regulamento" das subseções da Divisão. É o caso da Escola de Biblioteconomia cujas normas analisaremos neste capítulo, e sua repercussão no capítulo 4 e 5.
} 
construção de uma unidade na Mooca, enquanto estiveram ligados à Prefeitura. Além disso, as bibliotecas circulantes $^{71}$ foram um projeto-piloto e deveriam funcionar nos parques da capital.

Com o ingresso de Prestes Maia na Prefeitura Municipal, o serviço de Biblioteca Ambulante foi descontinuado, mesmo destino das bibliotecas-parque, as quais não chegaram a ser construídas. $\mathrm{O}$ fato de muitos dos projetos não terem se desenvolvido da forma como haviam sido inicialmente pensados serve como uma objetivação importante das disputas enfrentadas por Rubens Borba de Moraes com a finalidade de atender ao compromisso histórico assumido por ele próprio, por Mário de Andrade e pelo grupo de modernistas durante sua passagem pelo Departamento de Cultura.

Nesse sentido, no embate entre modernidade e tradição, saíram-se vencedores, no momento, os que apostaram na segunda. Prestes Maia era aliado político de Adhemar de Barros, interventor federal para o Estado de São Paulo, nomeado por Getúlio Vargas, em abril de 1938, em consequência do Golpe de Estado de 10 de novembro de 1937 e da decisão de desmantelar o grupo político de Armando Salles de Oliveira ${ }^{72}$. Prestes Maia entrou em $1^{\circ}$ de maio de 1938 e permaneceu na prefeitura até 10 de novembro de 1945.

O primeiro capítulo do Regulamento da Divisão de Bibliotecas, parte integrante do ato jurídico que cria oficialmente o Departamento de Cultura, define as funções de seus membros, a começar pela de Diretor, terminando na de serventes. O segundo capítulo versa sobre a Divisão de Expansão Cultural e logo em seguida é contemplada a Divisão de Bibliotecas. O modo como o Regulamento está redigido permite supor que esta divisão usufruía de grande importância para os projetos dos modernistas, dada sua posição no conjunto de capítulos que forma o Regulamento, cujo terceiro capítulo se desenvolve entre os artigos 101 e 194.

Logo no primeiro artigo, define-se que "todas as bibliotecas municipais de consulta pública” pertencem à Divisão. Em seguida, definem-se suas funções:

$1^{\circ}$ criar e organizar os serviços municipais de bibliotecas públicas;

$2^{\circ}$ organizar concursos literários de toda espécie, tendentes a incentivar a cultura nacional e completa-la em suas deficiências;

$3^{\circ}$ orientar os serviços de catalogação, classificação e conservação dos livros; $4^{\circ}$ procurar e manter intercâmbio com bibliotecas nacionais e estrangeiras;

$5^{\circ}$ organizar e dirigir anualmente um curso de biblioteconomia;

\footnotetext{
${ }^{71}$ Tratava-se da disponibilização de carros biblioteca que circulariam em dias pré-estabelecidos por parques da cidade. O objetivo era observar os usos da biblioteca para projetar a instalação de bibliotecas fixas naqueles parques.

${ }^{72} \mathrm{~A}$ decisão foi à resposta de Getúlio à insistência de Salles de Oliveira em acreditar que haveria eleições presidenciais em 1938 e, na visão getulista, ao erro mais grave do paulista em se credenciar para a disputa em oposição ao desejo de Vargas.
} 
$6^{0}$ divulgar mensalmente os dados estatísticos relativos ao movimento de consultas, entradas de livros e revistas;

$7^{\circ}$ adquirir, registrar e permutar duplicatas, propondo ao Diretor do Departamento a sua venda, quando necessária. (REGULAMENTO, 1935, p. 39 , grifo nosso).

Desde as primeiras disposições do Regulamento, é possível apreender diversas características essenciais para a Divisão de Bibliotecas. Por exemplo, a ideia implícita de sistema de bibliotecas, visto que seu artigo 101 determina que todas as bibliotecas municipais estivessem sob a gestão da mesma Divisão; desse modo, o Regulamento visava ordenar o campo de atuação das bibliotecas do ponto de vista administrativo. Outrossim, prevê a formação de bibliotecários, como atestado pelo item $5^{\circ}$ do artigo 102 , no qual se preconiza a construção de um curso de biblioteconomia. Até aquele momento, apenas a Biblioteca Nacional oferecia formação para bibliotecários ${ }^{73}$.

Note-se também a preocupação com a interface entre a biblioteca e a comunidade na qual está inserida, como demonstra o segundo item do artigo 102, que trata da promoção de concursos literários. Há um olhar ampliado sobre a atuação da biblioteca, pensada não apenas como um espaço de guarda da memória, mas também como um espaço em diálogo com a sociedade. Nesse sentido, os concursos literários pressupunham o envolvimento da biblioteca no cotidiano de seus usuários e o estímulo ao contato com a cultura letrada.

Do artigo 103 até o 105, o tema é a distribuição dos trabalhos administrativos entre a divisão e a subdivisão. Em seguida, inicia-se a parte dedicada a regrar o funcionamento da Biblioteca Pública Municipal, com a extensão de mais de cinquenta artigos (do 106 até o 160) que descrevem o que compreende cada unidade administrativa e os serviços prestados pela Biblioteca. Esta franqueava o acesso às coleções aos usuários com 10 anos de idade ou maiores (art. 117) e funcionava todos os dias da semana, inclusive aos domingos e feriados (art. 118), nos seguintes horários: de segunda a sábado, das 9 às 22 horas e aos domingos e feriados, das 13 às 18 horas (art. 139). Há uma mudança de concepção da biblioteca como serviço a ser prestado à sociedade, ainda que à primeira vista parecesse apenas uma questão burocrática: como ela empregava funcionários públicos, cujos horários de trabalho concentravam-se em um único período do dia, a divulgação do horário estabelecido representou uma ampliação que demonstrava interesse em proporcionar espaços de leitura que fugiam à regra do funcionalismo público vigente.

\footnotetext{
${ }^{73}$ Para uma comparação entre o curso da Biblioteca Nacional e o que significou o curso de Biblioteconomia proposto no projeto da Divisão de Bibliotecas, ver capítulo 4 da presente tese.
} 
É patente uma preocupação com o comportamento do leitor na biblioteca, conferindo ao documento um caráter normativo. Para utilizá-la, seria necessário lavar as mãos (art. 123), contribuir para manter "o máximo silêncio nas salas de leitura" (art. 125) e seguir as regras de requisição e acesso ao material (art. 127 até 130): o leitor requisita a "peça" a ser consultada através de uma ficha, aguarda em seu local (fixado por uma senha entregue no ingresso do salão) e, após seu uso, deverá devolvê-la ao funcionário, no balcão de atendimento. Este procedimento não valia para as obras de referência, disponíveis para acesso livre nas estantes das salas de leitura.

Havia um serviço telefônico para informar sobre a existência de livros na biblioteca (art. 132) e um livro de reclamações encontrava-se à disposição dos consulentes (art. 136). Este livro embasou a negociação junto à Prefeitura para solicitação de contratação de mais funcionários, a fim de melhorar os serviços prestados pela biblioteca. A participação dos leitores na formação de acervo se dava por meio de indicação de obras não existentes na coleção da Biblioteca, através de uma ficha criada com essa finalidade e preenchida pelos usuários (art. 137). Ainda a respeito da formação do acervo, os chefes de seção poderiam "propor aquisições que julgassem convenientes" (art. 149). As responsabilidades de cada funcionário estão meticulosamente descritas entre os artigos 149 e 160.

Os artigos 161 e 162 são fundamentais para se compreender uma grande novidade do projeto: as Bibliotecas Populares. Uma leitura atenta às filigranas do texto regulatório permite enxergar uma inflexão, como se tornará mais claro com a menção na íntegra dos artigos e o comentário posterior:

Art. 161 - As Bibliotecas Populares, localizadas em bairros operários, serão
constituídas: a) - de um serviço bibliográfico, destinado a orientar o povo em
suas leituras em tudo quanto se refira à sua especialização técnica ou
desenvolvimento cultural; b) - de um serviço cultural destinado a promover
cursos de vulgarização e conferências e a formar associações de caráter
educativo ou cultural; c) - de um serviço de leitura a domicílio mediante
empréstimo, destinado a facilitar consultas aos moradores dos bairros; d) - de
um serviço permanente de inquérito das exigências culturais e outras, das
camadas populares, por meio de cartas, queixas, pesquisas e jornais rurais.
Art. 162 - As Bibliotecas Populares, à medida que sejam criadas, adotarão
para consulta pública os mesmos princípios da Biblioteca Pública Municipal,
no que lhe for aplicável, expedindo-se regulamento suplementar
(REGULAMENTO, 1935, p. 48).

$\mathrm{O}$ art. 161, que se refere às Bibliotecas Populares, traz pela primeira vez no documento as palavras "povo" e "leitura", ao invés de "consulente" e "consulta". A ideia de povo, carregada de sentido cultural e político, pode ser aproximada à tradição de estudos folclóricos, 
originada na Europa durante a Primeira Revolução Industrial ${ }^{74}$ e expressa, no caso brasileiro, a partir do início da urbanização e industrialização, na passagem do século XIX para o XX. No grupo de modernistas, Mário de Andrade é o expoente máximo dos estudos sobre cultura popular e o documento apresenta uma sintonia com sua compreensão matizada e complexificada do que significa tratar de "povo", categoria a se apresentar em múltiplas faces e diversidade de subculturas. As Bibliotecas Populares pressupõem a concepção de "povo" como sujeitos dotados de demandas próprias, tanto do ponto de vista econômico-profissional "a especialização técnica" - quanto como produtores de sentido para suas existências - o “desenvolvimento cultural".

O plano de Bibliotecas (MORAES, 1978, 1981, 1983, 1986) é apresentado como um serviço prestado pelo poder público junto à população, calcado em uma mudança de paradigma no qual a instituição preza em primeiro lugar pelo interesse e necessidade de seu público. Neste caso, a preservação é entendida como um meio necessário para atingir seu fim: oferecer ao povo acesso à cultura letrada, identificada como a cultura própria da modernidade e indispensável aos projetos de modernização necessários a inserir o Brasil em posição de destaque no "concerto das nações "civilizadas".

As bibliotecas deveriam atuar como mobilizadoras sociais por meio da promoção de "cursos e conferências de vulgarização", "associações culturais", confecção de "inquéritos" e “comunicação com os jornais rurais", no que pode ser visto como uma tentativa de aproximação com a realidade de muitos moradores dos bairros onde essas bibliotecas seriam instaladas, pois seriam migrantes oriundos de regiões rurais pautadas pela produção de bens primários. Tratase de uma tentativa de contribuir para o sucesso na inclusão de uma parcela da população em transição de comunidades "arcaicas" para uma sociedade "moderna", vale dizer, letrada.

Outra informação relevante do artigo 161 diz respeito à possibilidade de se retirar livros para leitura em domicílio, característica marcante da concepção moderna de biblioteca, algo que viria a ser empregado também na Biblioteca Infantil. Esta é compreendida como extensível à casa do leitor, compreendido como portador (concretamente ou em potencial) de uma cultura de leitura, a ser exercida para espaços para além da biblioteca. É uma tentativa de "naturalização" do uso do objeto livro, de criação de habitus pelo que ele significa na cultura moderna, marcada pelo predomínio da escrita.

Ainda com o intuito de assimilação dos códigos da cultura letrada pelas camadas populares, o artigo 162 estabelece que o comportamento desejável para o frequentador da

\footnotetext{
${ }^{74}$ BURKE, P. Cultura popular na idade moderna: Europa, 1500-1800. São Paulo: Companhia das Letras, 2010.
} 
Municipal deve ser reproduzido pelo leitor das Bibliotecas Populares. Portanto, faz parte do plano que estas últimas sejam concebidas como espaço formativo de novos leitores, que devem se acostumar às regras de requisição e acesso ao acervo, em moldes similares ao da tradicional e primeira biblioteca pública da cidade.

Os artigos de 163 a 169 tratam das Bibliotecas Infantis e dedicam os dois primeiros para definir o que deveria ser a biblioteca infantil.

Art. 163 - As Bibliotecas Infantis serão constituídas por obras nacionais e estrangeiras de literatura infantil, de história, figuras, revistas infantis, recreativas e educativas, mapas e gravuras, moedas e selos.

Art. 164 - As Bibliotecas Infantis destinam-se a: a) - constituir um centro de diversões e descanso infantis, baseados no estudo; $b$ ) - despertar e desenvolver na criança o amor do estudo, a elevação do nível das leituras e o gosto pelas artes; c) - auxiliar as crianças à compreensão e amor da vida, da sociedade e da natureza, por meio de coleções especializadas, conferências, audições, filmes, reuniões e excursões ao campo, a exposições, fábricas e institutos científicos e artísticos; d) - estabelecer e auxiliar inquéritos sobre fenômenos psicológicos, sociais e etnográficos; e) - oferecer campo de observação, estudo e prática ao professorado em geral e aos alunos das escolas normais. (REGULAMENTO, 1935, p. 49).

A definição de biblioteca infantil é primeiramente apresentada pela descrição da composição do que seria o acervo. A destacar o reconhecimento da literatura infantil nacional e estrangeira como elemento formativo de crianças, ou, para ser mais preciso, dos indivíduos até 14 anos, para quem essas bibliotecas estavam destinadas (art. 165). A demonstração da preocupação de formação de sujeitos pela leitura aparece na descrição da instituição como um "centro de diversões e descanso infantil, baseados no estudo". A responsável pela implantação das bibliotecas foi Lenira Fraccaroli ${ }^{75}$. Vinda da biblioteca da Escola Caetano de Campos, contou com o apoio de Monteiro Lobato que, anos mais tarde, acabou dando nome à primeira biblioteca do sistema, hoje situada à Rua General Jardim, 485, na área central de São Paulo.

A inserção de dispositivos para as crianças no Plano de Bibliotecas entra no escopo da preocupação latente de reconhecimento da importância da infância na construção de Nação e se soma a esforços como o trabalho de Cecília Meirelles que, em 1934, organizou e dirigiu o Pavilhão Mourisco no Rio de Janeiro ${ }^{76}$. A novidade na proposta está no fato de que o plano

\footnotetext{
${ }^{75}$ Para saber mais sobre o trabalho de Lenira Fraccaroli, ver a dissertação de Fernanda de Lima Passamai Perez, defendida em 2021 pelo Programa de Pós-graduação em Ciência da Informação da ECA/USP, intitulada: Biblioteca e Educação Cultural: o projeto pioneiro da Biblioteca Infantil do Departamento Municipal de Cultura de São Paulo (1936-1940).

${ }^{76}$ Para saber mais sobre o projeto ver a obra de PIMENTA, J. S. Leitura, arte e educação: a biblioteca infantil do Pavilhão Mourisco (1934-1937). Rio de Janeiro: CRV, 2011.
} 
compreendia que a inserção na cultura letrada se daria de forma combinada com uma formação dos indivíduos em sua singularidade ("compreensão e amor da vida"), mas também em sua projeção na sociedade (“compreensão da sociedade e da natureza") por meio de sua participação em conferências, audições, filmes, excursões ao campo e exposições, ou seja, atividades culturais "comunitárias", compreendidas como espaços de formação coletiva.

A distinção sobre o papel educativo da biblioteca infantil fica clara na fala de RBM, ao rememorar suas divergências com Lenira Fraccaroli, responsável por dirigir os trabalhos na biblioteca infantil:

Vou explicar isso, que é muito engraçado. Quando eu quis fazer a rede de bibliotecas, naturalmente que pensei nas crianças. Havia uma seção de bibliotecas infantis, e toca eu a procurar uma bibliotecária infantil. Disseramme que havia uma moça, uma senhora chamada Dona Lenira Fracarolli, que tinha feito coisas extraordinárias. Era professora, mas tinha feito bibliotecas infantis em escola, e fiquei entusiasmado, pois ela tinha uma orientação muito boa, conhecia o problema do livro para a criança. Convidei-a para vir trabalhar comigo, e ela topou. Ela começou a trabalhar admiravelmente. Arranjei dinheiro para ela, arranjei tudo, arranjei até criança. E ela começou a fazer um serviço muito bom. Alugamos um prédio, e a biblioteca infantil era esplêndida. Mas, eu ia lá, visitava aquilo, e dizia: "Dona Lenira, a senhora está esquecendo de uma coisa. A senhora não é mais professora, a senhora agora é bibliotecária de uma biblioteca infantil. A sua orientação é de professora, a senhora dirige demais as crianças". Eu criticava a coisa de professora. Queria uma coisa mais de biblioteca infantil. E ela discutia muito comigo. Era uma senhora muito viva, muito inteligente, muito capaz, e tinha um carregado sotaque paulista. Então ela me dizia: "Senhor doutor, senhor doutor, o senhor está enganado. As crianças precisam fazer isto". E eu dizia: "Pois é, isso é escola, isso não é biblioteca" (MORAES, 1978, p. 11, grifo nosso).

A tensão manifestada no trecho acima indica que Moraes direcionava críticas à educadora por observar que ela "dirige demais as crianças". Para ele, a biblioteca deveria ter um escopo formativo diferente daquele previsto para o ensino e aprendizagem escolar, onde as crianças são submetidas a processos e atividades concebidos e controlados pelos educadores. A divergência na concepção da biblioteca pode ser identificada no artigo 161 do Regulamento, cujo propósito seria constituir "um centro de diversões e descanso", além de favorecer seu contato com as artes em diferentes formatos e manifestações, e, por conseguinte, "despertar e desenvolver na criança o amor do estudo". Para Moraes (1978, 1981, 1983, 1985, 1986), a atuação da biblioteca em relação à escola se diferenciaria no fato de que a primeira compreenderia a formação de sujeitos em sua singularidade pela liberdade a ele dada para que 
possa adentrar no universo dos livros sem o controle de um professor na intermediação de sua relação com o objeto, seus signos e significados.

Os artigos 170 e 171 tratavam das "Bibliotecas Parque", pensadas para difundir a cultura escrita a "frequentadores de jardins e às pessoas residentes em bairros afastados". Esta faceta de atuação da Divisão de Bibliotecas trouxe à tona o incômodo gerado na classe política a respeito dos resultados da ampliação da oferta de dispositivos culturais à população, especialmente das franjas para as quais ela sempre foi menos acessível.

O Regulamento previa a implantação de carros-bibliotecas em parques municipais que seriam progressivamente substituídos por prédios destinados não só a empréstimos de livros, mas também ao oferecimento de espaços públicos de leitura. Quando a biblioteca "ambulante" estava sendo reconhecida pela sociedade como um dispositivo de acesso aos livros e de leitura, Prestes Maia mandou descontinuar o serviço sob a alegação de que o combustível estava com preço muito elevado, encarecendo assim os custos para a Prefeitura.

À medida que foi se concretizando, o plano modernista de bibliotecas foi ganhando visibilidade social e foram-se complexificando também as relações políticas. Além do aumento no número de atores envolvidos na concretização das bibliotecas, entraram no jogo também as diferentes concepções sobre o papel social da biblioteca e o lugar do Estado diante da formação de novos leitores e de estudiosos sobre a cultura nacional. Intensificaram-se, desse modo, as disputas de forças que atuavam sobre as políticas públicas. Em país sem tradição letrada consistente, mesmo nos diferentes segmentos das elites que o constituíam, ações voltadas à renovação das bibliotecas e à constituição da Biblioteconomia encontravam barreiras de várias ordens, a exemplo das interferências de Prestes Maia nos projetos ligados à Divisão de Bibliotecas.

Devido à importância da Escola de Biblioteconomia na constituição do campo no país, organizamos a discussão sobre o tema em dois momentos. No primeiro momento, focaremos na leitura dos artigos 172 a 194, do Regulamento do Departamento, e que tratam das normas que nortearam a criação e sustentaram a Escola entre os anos 1936 e 1938. Aspectos ligados à concepção de biblioteca, Biblioteconomia e à mobilização em torno da profissionalização do campo serão desenvolvidas no capítulo 4.

No artigo 172 do Regulamento, a Escola de Biblioteconomia de S. Paulo é definida como "o curso de formação bibliotecária instituído pela letra "e" do art. 195 do Ato no 1.146 de 4 de julho de 1936". O artigo citado diz que é atribuição do Diretor da Divisão de Bibliotecas 
“organizar anualmente um curso de biblioteconomia"77. É notável observar-se que o que era para ser apenas um curso de preparação em Biblioteconomia, ou seja, iniciativa nos moldes de um curso preparatório para concurso ${ }^{78}$, se constitui como uma Escola de formação de bibliotecários. Segundo Moraes (1981), tal direção foi autorizada pelo prefeito Fábio Prado, para que, por meio dela, "bibliotecários e funcionários que trabalhavam em bibliotecas tivessem a oportunidade de aprender". Note-se que ao diretor da Escola cabiam funções legais, formativas e também burocráticas. Rubens Borba de Moraes era o responsável por representar "os atos" da Escola (Art. 172), aprovar os programas de ensino elaborados anualmente pelos professores (Art. 174), admitir ou não alunos com "títulos científicos, provenientes de escolas situadas em outro Estado ou no estrangeiro" (Art. 176).

Em tom normativo, o documento prescreve os pré-requisitos dos interessados na formação profissional em Biblioteconomia. O artigo 176 descreve:

Serão admitidos à matrícula os candidatos que, além das demais exigências deste Regulamento, apresentarem qualquer dos títulos seguintes: - diploma de bacharel em ciências e letras ou certificado de exames parcelados, em número de doze; - certidão de aprovação em exame vestibular de escola superior; diploma de professor normalista ou certidão de aprovação final do curso normal; - diploma de contador, expedido por escola reconhecida e fiscalizada. (único) - Os títulos científicos, provenientes de escolas situadas em outro Estado ou no estrangeiro, serão aceitos ou recusados, a juízo do Chefe da Divisão (REGULAMENTO, 1935, p. 52).

Como "demais exigências" constam no regulamento "ter mais de 18 e menos de 30 anos" (art. 177); realizar "provas vestibulares, segundo programa previamente anunciado aos candidatos" (art. 178); apresentação de "atestado de boa conduta e sanidade" (art. 180) - os dois últimos entendidos como etapas a serem ou não aplicáveis, de acordo com a determinação do chefe da divisão. Ainda assim, as exigências de perfil dos candidatos ao curso eram altas, previam a apresentação de "diploma de bacharel em ciências e letras" ou "certidão de aprovação em exame vestibular" ou "diploma de professor normalista", ou ainda, "diploma de contador",

\footnotetext{
${ }^{77}$ Para conhecer os detalhes da Lei 1146 de 7 de julho de 1936, cf.: SÃO PAULO (Cidade). Ato do Executivo Municipal de São Paulo no 1146 , de 4 de julho de 1936. Consolida e modifica disposições referentes aos serviços, repartições e funcionários da Prefeitura, e dá outras providências. Diário Oficial da Cidade, 07 jul. 1936, p. 1. Disponível em: http://legislacao.prefeitura.sp.gov.br/leis/ato-gabinete-do-prefeito-1146-de-7-de-julho-de-1936. Acesso em: 20 maio 2020.

${ }^{78}$ Em 1926, no mesmo ato que regulamentava a reorganização da Biblioteca Municipal (Ato 1 - apresentado por Raphael Archanjo Gurgel à Câmara Municipal), no capítulo II, artigo $10^{\circ}, 26^{\circ}$ parágrafo, previa-se a instalação "logo que se tornar possível" de um "curso prático de bibliothecosophia" a ser em tempo regulamentado. Proposta que foi concretizada em forma de palestras proferidas nas dependências do Instituto Histórico Geográfico no ano de 1935 .
} 
ou seja, não bastava só o interesse pelos livros, era exigida também uma formação em nível superior ou secundário.

Sobre a vida acadêmica do aluno, exigia-se presença em no mínimo $60 \%$ das aulas práticas e teóricas (art. 181) e as notas variavam entre 10 e 100, com um mínimo de nota acima de 40 para garantir a aprovação (art. 184). Os artigos entre 185 e 191 abordavam a vida acadêmica do aluno, especialmente no que diz respeito à sua frequência às aulas teóricas e práticas. A Escola previa que o aluno tivesse liberdade nas escolhas das disciplinas ou "cadeiras" - como era chamada no Regulamento - o que permitia que o aluno frequentasse "uma só cadeira do curso, bem como realizá-lo parceladamente em dois ou mais anos" (art. 192). O diploma de bibliotecário estava atrelado à finalização de todas as cadeiras que conformavam o curso (art. 192).

Em sua primeira fase, o curso previa quatro disciplinas distribuídas entre seus dois professores: Rubens Borba de Moraes e Adelpha de Figueiredo. Além de conduzir a Escola, RBM lecionava as matérias de "História do Livro" e "Bibliografia". Adelpha de Figueiredo, que já havia sido convidada por Moraes para dirigir a Subdivisão de Catalogação da Biblioteca Municipal, lecionava as disciplinas de "Catalogação" e "Classificação".

A estes profissionais, qualificados por meio do cumprimento do currículo exposto em grandes traços acima, se desenhava, no projeto de bibliotecas dos modernistas, a empregabilidade em um sistema de bibliotecas para o qual já se previa, inclusive, as regras para ampliação e desenvolvimento. Segundo Moraes (1981), o plano seguia duas vertentes: a de qualificação profissional que se articularia como um "movimento a favor das bibliotecas" e a de aumento na oferta de espaços de leitura cujo projeto seria

[...] pautado na oferta de bibliotecas e leitura e previa o crescimento do sistema de bibliotecas conforme o crescimento da cidade de São Paulo. E poderíamos mais tarde, em um bairro novo, em situação nova, abrir novas bibliotecas. (MORAES, 1981, p. 5)

Moraes ressalta que a oferta de bibliotecas deveria ser pautada pelo "crescimento da cidade de São Paulo", que estava em processo de urbanização e industrialização. Para isso, a Divisão contava com a Divisão de Documentação Histórica e Social com o objetivo de desenvolver estudos sociais para apontar as "necessidades" culturais, educacionais e econômicas da população da cidade de São Paulo, incluindo especialmente os imigrantes operários, suas famílias e crianças. 
Estudando-se o desenvolvimento de sua população, observa-se um movimento intenso de imigração de uma para outras zonas. A causa disso é essencialmente econômica. São zonas novas que surgem, promissoras e exuberantes de vida e de energia latentes atraindo os homens das zonas velhas e exploradas. Com os elementos estatísticos de que dispomos, torna-se fácil acompanhar o desenvolvimento demográfico de São Paulo, de 1890 a 1934, com os dados colhidos nos quatro últimos recenseamentos. (GODOY FILHO, 1935, p. 78)

Havia grande preocupação dos modernistas ${ }^{79}$ em compreender o povoamento de São Paulo para além da face "essencialmente econômica" que motivava a migração de famílias do interior para a capital do Estado. Além do mais, acompanhar o desenvolvimento demográfíco de São Paulo, após a implantação do Departamento de Cultura, seria o caminho, para "agir em profundidade realisticamente, lentamente, sem esperar resultados imediatos (MORAES, 2011, p. 216), e assim efetivar o sistema de bibliotecas", conforme demonstrado na passagem abaixo:

[...] o meu slogan era: uma biblioteca não adianta nada. É preciso fazer uma rede de bibliotecas. Eu me batia por esse negócio de rede de bibliotecas, falava e doutrinava, escrevia e dava entrevista. Se se tivesse escutado o nosso plano, já em 40 e poucos, São Paulo teria dez bibliotecas de bairro e uma biblioteca central de referência. Depois era só construir outras a cada três, quatro, cinco anos, conforme as necessidades. Como todas as dez estavam planejadas em terrenos públicos e com possibilidade de expansão o plano estaria feito. (MORAES, 1978, p. 9)

Pautar a oferta de bibliotecas às necessidades de crescimento da cidade era um dos slogans de RBM, que defendia as bibliotecas como instituição essencial no desenvolvimento de uma população urbana, bem como do Departamento de Cultura, que apoiara a criação de um "sistema de bibliotecas" 80 , ao invés de bibliotecas isoladas.

No próximo capítulo, discorreremos sobre a Escola de Biblioteconomia em suas ações e resistências conceituais e políticas. Veremos que a proposta da Divisão de Bibliotecas era

\footnotetext{
${ }^{79}$ Os estudos conduzidos e sistematizados pela Divisão de Documentação Histórica e Social eram publicados na Revista do Arquivo Municipal, órgão oficial do Departamento de Cultura. Para saber mais sobre a importância da Revista dentro do projeto do Departamento de Cultura, ver a tese de Silene Claro (2008). Cf.: CLARO, S. F. Revista do Arquivo Municipal de São Paulo: um espaço científico e cultural esquecido (proposta inicial e as mudanças na trajetória - 1934-1950). 2008. Tese (Doutorado em História Social) - Faculdade de Filosofia, Letras e Ciências Humanas, Universidade de São Paulo, São Paulo, 2008. Disponível em: https://teses.usp.br/teses/disponiveis/8/8138/tde-09022009-164245/pt-br.php. Acesso em: 03 maio 2021.

${ }^{80}$ Moraes, por diversas vezes em seus discursos, trata "Rede de bibliotecas" e "Sistema de bibliotecas" como sendo sinônimos. Entendemos que a ideia adotada no Departamento de Cultura refere-se ao conceito de "Sistema de Bibliotecas" que compreende uma biblioteca principal, no caso a Biblioteca Pública Municipal (também chamada de Biblioteca de Referência ou Biblioteca Central) e as bibliotecas de bairro que por vezes são retratadas como "Bibliotecas ramais". Observamos que as bibliotecas de bairro e infantil reportavam-se a Rubens Borba de Moraes, o que nos faz observar que do ponto de vista administrativo e financeiro as bibliotecas eram extensões da Biblioteca principal - a Biblioteca Pública, atual Mário de Andrade - já do ponto de vista pedagógico, podemos dizer que a biblioteca infantil gerida por Lenira Fraccaroli era, por sua vez, autônoma.
} 
objetiva, abrangente e visionária, pois esperava-se resolver o problema da "miséria cultural" e, com isso, a do país em seus múltiplos aspectos. Da mesma forma que o Manifesto da Escola Nova, em 1930, afirmava ser a Educação o instrumento básico da superação do atraso, os idealizadores do Departamento de Cultura, acreditavam que o motivo central do atraso era cultural. Nesse sentido, RBM atuou no sentido de ampliar, com a Escola, teia bibliotecária atuante em nível nacional que culminaria em um movimento de constituição e consolidação do campo da Biblioteconomia nas décadas seguintes, agregando novos aspectos e iniciativas às desenvolvidas, a partir da constituição do Departamento de Cultura e da sua Divisão de Bibliotecas. 


\section{FORMAÇÃO DE UM BIBLIOTECÁRIO PARA UMA TEIA BIBLIOTECÁRIA}

Quando Moraes assumiu a Direção da Divisão de Bibliotecas, em 26 de novembro de $1935^{81}$, trouxe consigo o repertório cultural construído ao longo de sua carreira intelectual e política, o que viria a ser refletido nas ações que liderou, conforme veremos neste capítulo. Para compreendermos melhor o que significaram as ações de Moraes na instauração da Escola de Biblioteconomia, em 1936, na cidade de São Paulo, organizamos o capítulo em três partes: na primeira, analisaremos discursos internos à Escola de Biblioteconomia, referentes a questões envolvendo a temática do livro, da biblioteca e do bibliotecário. Em seguida, trataremos do reconhecimento de RBM por pares da teia bibliotecária internacional, expresso através de menções a ele em eventos da ALA - American Library Association. Esta será também uma oportunidade para retornarmos a questões envolvendo livro, biblioteca e bibliotecários, na medida em que as experiências internacionais dos anos 1930 validam em certos aspectos sua formação inicial, ao mesmo tempo em que expandem suas concepções, fazendo-as dialogar com outras formas contemporâneas de enxergar a biblioteca. No final do capítulo, recorreremos ao processo que culminou no fechamento da Escola de Biblioteconomia da Divisão de Bibliotecas para analisar as disputas em torno da compreensão do que deveria ser a Biblioteconomia no país, tema que será explorado no quarto capítulo desta tese.

\subsection{O discurso inaugural de Rubens}

A Escola de Biblioteconomia do Departamento de Cultura iniciou suas atividades em 17 de agosto de 1936, com o discurso de abertura realizado por Rubens Borba de Moraes ${ }^{82}$, cujas primeiras frases trazem uma justificativa para sua criação:

\footnotetext{
${ }^{81}$ Em julho de 1935, Rubens Borba de Moraes tinha sido comissionado junto ao Departamento de Cultura. Em novembro de 1935, Eurico de Góes é aposentado no cargo de Diretor da Biblioteca Municipal. Em 26 de novembro de 1935, Moraes foi nomeado Diretor da Divisão de Bibliotecas - que tinha entre suas atribuições a direção da Biblioteca Pública e da Escola de Biblioteconomia. Segundo o próprio Moraes, a opção de deixar o cargo vitalício para assumir a liderança do projeto bibliotecário fez com que ele tivesse perdas salariais.

${ }^{82} \mathrm{O}$ discurso foi sucedido pela primeira aula do curso de catalogação, proferida por Adelpha Rodrigues de Figueiredo. O acervo da Escola de Biblioteconomia da FESP preserva a transcrição da aula de Figueiredo, assinada por ela própria e datada de 17 de agosto de 1936. A aula de Moraes está alocada no fundo do Departamento de Cultura do Instituto de Estudos Brasileiros, e o discurso inaugural de Moraes está abrigado no Fundo Rubens Borba de Moraes na Biblioteca Brasiliana Guita e José Mindlin, sem indicação de data, mas com a seguinte frase final:

"Dou a palavra a d. Adelpha Rodrigues de Figueiredo, B[achelor] S[cience] in library service pela Universidade de Columbia, que pronunciará a primeira aula". Nesta breve frase há diversos temas a merecer nossa atenção. $\mathrm{O}$ primeiro é a apresentação da "lente" da disciplina de catalogação que já dispunha de um grau de nível superior na área de biblioteconomia, uma novidade que se pretendia firmar com o curso. Moraes trouxe para o início do curso um saber técnico reconhecido no âmbito internacional, demonstração de sua preocupação em afirmar a importância
} 
A Divisão de Bibliotecas do Departamento de Cultura tem o prazer de inaugurar hoje o $1^{\circ}$ curso de biblioteconomia de São Paulo. A julgar pelo número de pessoas inscritas e pelos comentários despertados nos meios intelectuais, parece-nos que a iniciativa foi acertada. E é com a maior alegria que a Divisão de Bibliotecas do Departamento de Cultura vê repercutir tão favoravelmente o seu novo empreendimento. O Departamento de Cultura, tão seriamente empenhado em dotar S. Paulo de um aparelhamento bibliotecário à altura do seu desenvolvimento, organizou, depois de longos estudos, um plano que se irá executando paulatinamente. (MORAES, 1936, p. 1)

Já em sua primeira turma, o curso havia sido bastante procurado dentro do Município ou alhures, com manifestações de pessoas de outras unidades da federação ${ }^{83}$, fato que, segundo Moraes, comprovaria a necessidade de sua existência. Ao mesmo tempo, RBM faz questão de identificar o curso como "o primeiro de São Paulo", declaração que Adelpha de Figueiredo, mais tarde, não endossará. Ela havia participado, em 1929, do "curso de bibliotecários" oferecido no Instituto Mackenzie de São Paulo, sob a orientação da bibliotecária estadunidense Dorothy Muriel Geddes (também referenciada na literatura pela forma nominal adotada após seu casamento, isto é, Mrs. Arthur E. Gropp). Segundo ela, a Sra. Gropp "foi a verdadeira fundadora da biblioteconomia moderna, em São Paulo" (FIGUEIREDO, 1945) ${ }^{84}$. Na verdade, as declarações de Moraes e Adelpha de Figueiredo podem ser interpretadas como indício de disputas internas ao campo, bem como, sobre o que se entendia por biblioteconomia moderna, e também sobre "curso", já que as concepções e os modos de organização eram distintos. Por outro lado, a decisão de Moraes em identificar o curso como o "primeiro de São Paulo" remete a narrativas do grupo que ocupava a direção do Departamento de Cultura e que tinham a função

de uma formação especializada no desenvolvimento de um campo bibliotecário. Com o exemplo de Figueiredo, Moraes reafirma a constituição de um acúmulo de reflexões epistemológicas como métrica para avaliar quem pode ou não ser considerado como bibliotecário - é preciso dotar os bibliotecários com um conjunto de preocupações, técnicas e conceitos próprios da área - sem se esquecer da exigência de erudição humanística, também propalada por Moraes.

${ }^{83} \mathrm{~A}$ demanda social pelo curso pode ser comprovada pelo número de correspondências recebidas pelo Departamento de Cultura, tendo como remetentes tanto candidatas que se apresentam como interessadas pessoais quanto prefeitos que visavam o desenvolvimento das políticas de bibliotecas em seus respectivos municípios. O conjunto de correspondência se encontra sob a guarda do Arquivo Histórico da Biblioteca Municipal Mário de Andrade.

${ }^{84}$ Neste capítulo, veremos que disputas inscritas na história da Biblioteconomia podem estar relacionadas às divergências de sentidos sobre a formação de bibliotecários e no que se entende por essencial na formação profissional. Ou seja, a aceitação ou não do curso oferecido no Mackenzie como elemento que contribuiu com a formação da máquina bibliotecária em São Paulo revela um espaço de disputa sobre o que deveria ser a biblioteconomia e o curso de formação profissional. Debates que ficarão mais evidentes quando analisarmos a aula inaugural do curso proferida por Adelpha de Figueiredo, tema do próximo tópico deste capítulo. Em uma conferência no Departamento do Serviço Público de São Paulo (DASP), Adelpha de Figueiredo afirma: "Apareceu então, em outubro de 1929, a primeira turma de candidatos ao curso de bibliotecários que o Mackenzie criava. [...] a vossa conferencista chegou, depois de oito (8) meses de curso intensivo, em maio de 1930, portanto, ao fim do primeiro curso de biblioteconomia que São Paulo teve.” (FIGUEIREDO, 1945, p. 9). 
de reservar para São Paulo um papel de ponta na modernização do Brasil, assim como na busca de sua redefinição identitária.

Após o relativo sucesso político da Revolta Constitucionalista de 1932, as elites paulistas se viram como gabaritadas a pleitear a volta de seu controle sobre o país, mas em condição diferente do estabelecido na Primeira República. O grupo político que bancou a criação do Departamento de Cultura, chefiado por Armando Salles de Oliveira, desejava unir as expectativas de 1930 e 1932, isto é, descartava a volta ao regime da Primeira República e não aceitava participar do grupo de alianças que mantinham Vargas no controle do sistema político nacional. Em uma escala microscópica, quando Moraes menciona de forma indireta que a busca pelo curso de Biblioteconomia envolvia até pessoas de outros estados, parece ser uma prova do acerto das intenções do grupo em ser vanguarda no empreendimento de uma Biblioteconomia brasileira moderna.

Moraes menciona que São Paulo "merece um curso à altura de seu desenvolvimento", e se utiliza de imagem de retórica para legitimar as pretensões políticas desse grupo, na medida em que eles desejam se apresentar tanto como distintos do que foi a oligarquia que constituiu o PRP, quanto dos grupos em torno de Vargas - ambos associados a formas distintas de atraso. A formação de "quadros técnicos" para atuar em bibliotecas pode ser interpretada, assim, como parte da construção discursiva sobre a cidade de São Paulo como força motriz do desenvolvimento nacional, algo que pode ser novamente identificado em outros trechos do mesmo discurso de Moraes:

Tem parte preponderante, nesse plano, a formação de bibliotecários. E não poderia ser de outra maneira. A formação técnica de um pessoal especializado, a instrução de verdadeiros bibliotecários, a admissão aos cargos de pessoas que possuem habilitação comprovada são indispensáveis, uma vez que se queira organizar entre nós verdadeiras bibliotecas. Vale uma biblioteca o que valem seus bibliotecários, diz um axioma antigo. É verdade. Mas entre nós a culpa das bibliotecas mal organizadas nem sempre cabe ao bibliotecário. Como culpar de ignorância uma pessoa, quando ela não tem possibilidade de aprender? Se não existe escola especializada entre nós, como podemos exigir especialistas? Sim, especialista, técnico, porque o bibliotecário de hoje não é mais um "homem que gosta de ler". O fato de gostar de leitura não é uma razão suficiente para uma pessoa aprender a ser bibliotecário, como não me parece razoável que um amador de viagens se ache com direito de ser piloto de navio. (MORAES, 1936, p. 1)

A preocupação de Moraes em afirmar a importância da "formação", "instrução" e "admissão" de bibliotecários especializados traduz a visão que os modernistas tinham sobre o que entendiam como campo bibliotecário. A preocupação em ressignificar a biblioteca como 
instância participante ativa dos processos de "democratização do mundo" culminaria na institucionalização das bibliotecas em dois caminhos: 1) criar instâncias de reflexão acerca do que é ser bibliotecário e proporcionar preparação técnica; 2) simultaneamente a isso, regrar o mercado profissional para restringi-lo aos que tivessem percorrido essas instâncias, deixando assim de ver os bibliotecários como uma mera ocupação profissional para enxergá-los como agentes históricos (SILVEIRA, 2008), profissionais das "verdadeiras bibliotecas", conectadas ao contexto de urbanização, industrialização e complexificação das teias sociais.

Ainda neste trecho, Moraes traz informações do que pensa acerca de como deveriam ser repensados os papéis e a identidade do bibliotecário e interpela por uma saída da biblioteca do âmbito do que é exclusivamente individual para ampliar seu acesso a todos. No período em que a biblioteca pertencia a um universo particular, de um sujeito ou de um pequeno grupo de letrados, o problema da biblioteca era atribuído ao bibliotecário. Na visão inovadora de Moraes sobre as bibliotecas, demanda-se uma reflexão coletiva sobre qual o papel do bibliotecário. A resposta de Moraes é concretizada na oferta de um curso de formação profissional para bibliotecários oferecido por uma escola pública. A sociedade brasileira era convidada pelos modernistas a decidir qual deveria ser o papel das bibliotecas ofertadas ao povo, levando-se em consideração as transformações sociais já referidas e o fato fundamental de que as exigências coletivas eram muito maiores do que a simples soma das exigências individuais de seus leitores. Dito de outra forma, a sociedade em ebulição encontraria nas bibliotecas, e, portanto, nos bibliotecários, uma instância mediadora para a inserção dos seus membros iletrados na cultura escrita, ou, de forma mais ampla, mediadora da interação dos brasileiros com um mercado editorial em explosão, tanto no número de títulos quanto em temas, causa e consequência do período de instabilidade característica dos anos 1920 e 1930. Ainda sobre a identidade do bibliotecário e o papel da biblioteca, RBM continua:

É muito interessante notar-se a evolução da profissão de bibliotecário. Enquanto o livro foi uma coisa rara, o bibliotecário foi, sobretudo, um 'caçador de livros'. A ele competia organizar a 'bandeira de caça ao livro' e trazer as 'peças' aos grandes centros consumidores ou às bibliotecas. $\mathrm{O}$ bibliotecário era bibliófilo, um homem cujas tendências o impeliam a dedicarse a essa ocupação de colecionador de livros. A produção era escassa. Uma vez reunida, era quase que só conservá-la. O bibliotecário não tinha quase que outra ocupação que a de conservar aquilo que reunia. Ele, aliás, não se chamava bibliotecário, mas 'conservador': conservador de tal biblioteca. A concepção que se tinha então de uma biblioteca era de 'um templo do livro'. Templo, isto é, casa onde se adora uma divindade, onde penetram iniciados. (MORAES, 1936, p. 2) 
A alegoria da "bandeira" como referência ao bibliotecário e a de "templo" para se referir à biblioteca conformam uma visão crítica sobre a história das bibliotecas e de quais os desafios necessários para vencer o fardo legado por essa herança, no Brasil. A "bandeira" é, ao mesmo tempo, um dos fenômenos históricos mais importantes para a ocupação das terras paulistas/paulistanas e origem de um mito fundador sobre a história. Coerente com a tradição modernista, Moraes parece indicar um questionamento sobre o aspecto positivo atribuído a esse mito fundador, pois equipara o bibliotecário ao bandeirante e o livro ao papel de indígena a ser escravizado através do uso do vocábulo "peça", utilizado no linguajar dos bandeirantes para se referir ao que hoje chamamos de "nativo". Pode-se concluir então que o livro se torna um escravo do leitor e do bibliotecário, conferindo um caráter negativo ao modo como esta relação se desenvolvia, da qual este último era apenas o "conservador" de uma biblioteca compreendida como "um templo" de adoração para "iniciados". Ao escolher a palavra "templo", Moraes pode ter buscado um diálogo com duas tradições:

1) O cientificismo que - não obstante o clima de pessimismo estabelecido pela crise econômica mundial de 1929 e marcante na década de 1930 - ainda emplacava uma visão de ciência não apenas oposta às visões religiosas do mundo como também superior a elas, em diversos aspectos. Ver a biblioteca como uma instituição religiosa seria, portanto, defini-la como um espaço de afirmação do obscurantismo, em gritante contradição com as expectativas sociais construídas no entorno dessa instituição;

2) Em diálogo com o cientificismo, boa parte da emergente literatura sobre a identidade brasileira apostava na leitura do passado colonial como um período marcado pelo domínio das ideias religiosas sobre a sociedade, e dos efeitos negativos desse domínio. ${ }^{85}$ Afirmar que a biblioteca era vista como "templo" indica que Moraes considerava tal perspectiva da existência da biblioteca como algo a se evitar por seu caráter excludente.

\footnotetext{
${ }^{85}$ A preocupação com o tema era cara aos modernistas. Oswald de Andrade, no Manifesto Antropofágico, publicou: "Contra o Padre Vieira. Autor do nosso primeiro empréstimo, para ganhar comissão. O rei-analfabeto dissera-lhe: ponha isso no papel, mas sem muita lábia. Fez-se o empréstimo. Gravou-se o açúcar brasileiro. Vieira deixou o dinheiro em Portugal e nos trouxe a lábia. $\mathrm{O}$ espírito recusa-se a conceber o espírito sem o corpo. $\mathrm{O}$ antropomorfismo. Necessidade da vacina antropofágica. Para o equilíbrio contra as religiões de meridiano. E as inquisições exteriores". A menção ao Pe. Vieira, zênite da produção literária colonial e religiosa, apresenta de forma lapidar o modo como o manifesto se contrapõe a esse passado. Ao estilo iconoclasta de Oswald, a virtuosidade do maneirismo barroco se vê reduzida à condição de "lábia" entreguista da riqueza nacional. E caso isso não fosse suficiente, Oswald ainda apela à luta contra "as religiões do meridiano" e as "inquisições". Cf. ANDRADE, O. de. O manifesto antropófago. In: TELES, Gilberto Mendonça. Vanguarda europeia e modernismo brasileiro: apresentação e crítica dos principais manifestos vanguardistas. 3. ed. Petrópolis: Vozes; Brasília: INL, 1976. Disponível em: https:/www.ufrgs.br/cdrom/oandrade/oandrade.pdf. Acesso em: 27 mar. 2021.
} 
Um templo exige dos iniciados um conhecimento prévio não compartilhável com os de fora e que autoriza a hierarquização dos usuários desta instituição como superiores ao restante. Nesta perspectiva não existe uma dimensão pública da biblioteca, pois a instituição só existe para aqueles poucos que têm o privilégio de frequentá-la.

Se a leitura do passado colonial indicava o que precisaria ser superado, as "máquinas"86, as "engrenagens", a velocidade dos automóveis e trens e o ritmo frenético das greves e sublevações dos anos 1920 exigiam uma resposta rápida e impunham aceitar que o mundo e a cidade de São Paulo estavam em transformação, com a emergência de grandes grupos sociais, como o operariado, saídos do anonimato para se constituírem, na sua condição coletiva, como sujeitos a compreenderem e a participarem das transformações. A modernidade se constituía sob o signo da democratização e era urgente considerar seu impacto na relação com os livros:

A democratização do mundo revolucionou esse conceito. O livro não é, hoje em dia, um privilégio, manusear in $4^{\circ}$ s não é mais uma coisa difícil, ao alcance apenas de uma elite de iniciados. Uma biblioteca não é mais um centro de cultura para homens cultos, mas um centro de estudos proporcionando as mesmas possibilidades para todos. O bibliotecário não é mais um erudito perdido entre livros raros, lendo e estudando para si. É um organizador, um homem que possui um preparo técnico para fazer funcionar uma organização "sui generis". (MORAES, 1936, p. 1)

A "democratização do mundo" corresponde ao crescimento exponencial da produção e circulação dos livros e, para tanto, seria necessário contar com bibliotecários que compreendessem seu papel de mediadores culturais de sujeitos geralmente excluídos da cultura letrada, mas lançados em cheio, via êxodo rural ou imigração do estrangeiro para o país, nos processos de transformação econômica, política e cultural - desta última, resulta um acúmulo de reflexão criativa sobre a identidade nacional. Esse acúmulo se expressa através de um aumento significativo da produção editorial mundial e brasileira. Esta nova configuração da relação dos livros com a sociedade colocaria a nu as dificuldades impostas pela visão tradicional do que era ser bibliotecário ${ }^{87}$, que conforme já visto linhas acima, correspondia a um período

\footnotetext{
${ }^{86}$ Moraes (1943) se apropria do vocabulário e expressões ligadas à industrialização, tais como "máquina bibliotecária" e "engrenagem", para se referir à força que acredita encontrar na classe bibliotecária para forjar as transformações no âmbito cultural que os modernistas enxergavam como necessárias.

${ }^{87} \mathrm{Com}$ um pouco de ousadia é possível utilizar essa chave de leitura para compreender o transcorrido entre Mário de Andrade e Eurico de Góes, do qual resultou a aposentadoria compulsória deste último do cargo de Diretor da Divisão de Bibliotecas, em novembro de 1935. Do ponto de vista dos modernistas, o projeto de bibliotecas populares era fundamental para superar a visão tradicional das bibliotecas e dos bibliotecários. Para Eurico de Góes, foi impossível enxergar as transformações que essa nova visão de biblioteca e bibliotecário poderiam trazer de positivo para sua rotina profissional.
} 
em que prevaleciam no Brasil as relações econômicas e sociais regidas pela lógica colonial escravocrata. Esse passado era contraposto ao período coevo à criação da Escola de biblioteconomia, erigido sob o signo da liberdade - tanto na relativa facilidade de produção, dado o aumento da produção editorial, quanto pelo crescimento do mercado de leitores e de críticos ávidos pelas novidades editoriais. A estas novidades era imperativo responder com uma ampliação de olhar sobre o bibliotecário que evitasse o reducionismo de seu papel social:

Enquanto a produção da imprensa foi pequena e as bibliotecas frequentadas por gente já habituada ao manuseio dos livros, por pessoas que iam a elas procurar uma determinada obra, a função do bibliotecário foi das mais simples. Estava em manter mais ou menos em ordem as peças e oferecer ao leitor uma lista das obras que possuía. (MORAES, 1936, p. 2)

Em suma, o papel social do profissional na sociedade brasileira em vias de ingresso no capitalismo industrial $^{88}$ extrapolaria as atividades de conservação e gestão de acervos. Ao definir a biblioteca moderna como "um centro de estudos proporcionando as mesmas possibilidades para todos", Moraes traz uma interpretação de que as bibliotecas seriam uma das forças motrizes do desenvolvimento nacional, com o papel estratégico de tornar a cultura letrada acessível para uma parcela crescente da população, exposta às transformações sociais cujos primeiros efeitos já começariam a se tornar visíveis na cidade de São Paulo. Para o grupo político do qual RBM fazia parte, a urbanização e a industrialização paulistanas tinham uma apreciação positiva e justificariam suas pretensões de irradiação das ações locais em dimensão nacional $^{89}$.

Moraes aspirava que a Escola de Biblioteconomia fosse - em conjunto com a promulgação de leis - a "parte preponderante do plano" para que o Estado induzisse e regulasse a formação de um mercado de trabalho para os bibliotecários. O poder público também era chamado a agir no processo de ampliação de oferta de bibliotecas, entendido como condição sine qua non ao projeto de democratização cultural. Com efeito, durante a aula, Moraes cita o Ato Municipal n. 1.146/1936 de São Paulo, que passou a exigir pré-requisitos para o exercício

\footnotetext{
${ }^{88}$ Não se pode ignorar que o capitalismo industrial de um país que ocupa a posição do Brasil na divisão internacional do trabalho não corresponde àquela dos países que embarcaram na Revolução Industrial em seu primeiro momento (1750-1850, grosso modo) e que ainda hoje ocupam, em sua maioria, o posto de principais arrecadadores da riqueza produzida. Não se trata de igualizar a posição brasileira à de uma Inglaterra, EUA ou Alemanha, mas de admitir que o ingresso no rol de países industrializados impôs mudanças na escolarização/universitarização e nas experiências de sociabilidade e lazer que modificaram profundamente as formas de produzir e fazer circular as manifestações culturais. No âmbito da Biblioteconomia a profissionalização e a universitarização se interpelaram reciprocamente.

${ }^{89}$ No segundo capítulo, apresentamos as motivações que conduziu o grupo de intelectuais do qual RBM fazia parte a proporem a Divisão de Bibliotecas dentro do Departamento de cultura.
} 
do cargo de bibliotecário-chefe e de diretor da Divisão de Bibliotecas, a saber: ser portador de um diploma de curso superior e também do curso de Biblioteconomia. Naquele momento, havia apenas duas instituições em todo o país que ofereciam o curso de formação de bibliotecários: além da própria Escola do Departamento de Cultura, contava-se nessa categoria a Biblioteca Nacional, no Rio de Janeiro, então capital federal. A estrutura do curso é apresentada no final do discurso inaugural, como segue:

Neste primeiro semestre, como os senhores já sabem, a escola dará somente a
$1^{\text {a }}$ cadeira de seu curso: catalogação e classificação. Insisto: a $1^{a}$ cadeira. No
fim deste ano, os senhores não serão, ainda, oficialmente, bibliotecários
formados. O Estado exige mais. Outros conhecimentos, além destes são
indispensáveis para quem pretende dedicar-se à carreira dos livros. Essas
outras matérias serão ensinadas, no próximo ano, durante os 2 semestres. É,
portanto, de ano e meio a duração do curso completo de biblioteconomia do
Departamento de Cultura. Não é muito. É esse um tempo mínimo para se
poder formar, sem aprofundar muito, bibliotecários eficientes. Estamos certos
que, entre os alunos desta primeira turma, entre os quais vemos alguns que já
provaram, na prática, serem bibliotecários de primeira ordem, S. Paulo
encontrará os homens capazes de levar nossas bibliotecas à altura de nossa
cultura. (MORAES, 1936, p.1)

A respeito da exigência criada pelo ato municipal, cumpre observar que ela já consistia em prática adotada explicitamente na Escola de Biblioteconomia à qual se somava um elemento adicional: pela análise da lista de ingressantes da Escola em 1936 e de suas ocupações, é possível afirmar que a maior parte deles já era atuante em bibliotecas e, por isso, buscariam, naquele espaço, a formação que legitimasse sua atuação. Além disso, para serem admitidos pela escola, já deveriam ter apresentado um diploma de bacharel, contabilista ou normalista, ou ainda uma aprovação em vestibular. Vê-se, portanto, como era elevado o nível de exigência para que seu pertencimento ao campo profissional fosse oficialmente reconhecido. As cartas de recomendação dos estudantes eram, em sua maioria, assinadas por políticos com declarações entusiásticas de interesse em modernizar as bibliotecas dos municípios de suas bases eleitorais.

Para RBM “a criação da Escola de Biblioteconomia e a exigência do diploma para o concurso inicial na carreira de bibliotecário inauguram uma nova era para as bibliotecas paulistas [cujos] resultados, estou certo, não se farão esperar" (MORAES, 1936, p.1). Após estas palavras de incentivo aos estudantes, apresenta a estrutura do curso e fornece pistas sobre o que entendia como biblioteconomia, nó górdio das disputas entre os professores da Escola de Biblioteconomia, como se verá algumas linhas abaixo neste mesmo texto. RBM atribui o mesmo peso aos temas das disciplinas de "História do Livro" e "Serviço de Referência" que ao tema escolhido para iniciar o curso ("Catalogação e Classificação"). A decisão de iniciar por 
esta matéria é digna de atenção, tendo em vista que os bibliotecários matriculados no curso já haviam acumulado algum nível de conhecimento empírico sobre o tema, através do exercício de suas funções, conforme o próprio Moraes reconhece durante o discurso.

A intervenção de Moraes termina com a associação da Biblioteconomia à origem do livro como documento escrito, entendida por ele como parte essencial na formação de uma "verdadeira cultura", o que implicou reforçar que nem todos os conhecimentos a serem transmitidos no curso teriam uma "finalidade prática". Feita a ressalva, Moraes passa a palavra a Adelpha de Figueiredo, responsável por proferir sua aula inaugural, a ser brevemente analisada na presente tese, na medida em que pode ser lida como uma réplica a diversas afirmações de Moraes em seu discurso.

\subsection{A resposta de Adelpha de Figueiredo}

No início de sua aula, Adelpha de Figueiredo demonstra sintonia com os propósitos modernistas ao enfatizar que o objetivo das bibliotecas era "tornar acessível, no sentido mais amplo da expressão, a herança de cultura a que todos têm direito". Para a realização desse objetivo, é necessário:

1. Tornar essa herança um elemento vivo, não apenas colecionando livros, mas fazendo-os circular.

2. Relacionar a biblioteca não só com as escolas e a classe adulta erudita, mas ligá-la estreitamente a lojas, fábricas, sindicatos diversos, partidos políticos, organizações religiosas, hospitais, casas de caridade, áreas rurais, quartéis de polícia e de bombeiros, etc.

3. Fazer propaganda, por meio de conferências, jornais, rádio, cartazes e, acima de tudo, pela eficiência do trabalho da própria biblioteca.

4. Estabelecer a semana integral de funcionamento e o dia integral (12 horas). (FIGUEIREDO, 1936, p. 1)

Adelpha de Figueiredo reconhece a biblioteca como uma instituição de memória que, sob a influência das mudanças sociais pulsantes, sofreu alterações em seus objetivos. Se antes a preservação do acervo se sobrepunha ao acesso ao patrimônio cultural, a prioridade passaria a ser a difusão cultural, entendida por ela e por RBM como instância capaz de transformar a biblioteca templo em um "elemento vivo" reconhecido pela sociedade. Tal declaração, de início, reforça o espírito de democratização cultural proposto no regulamento da Divisão das Bibliotecas e concretizado nas ações da Divisão ${ }^{90}$, a qual se preocupava inclusive com medidas

\footnotetext{
${ }^{90}$ Assunto sobre o qual já discorremos no capítulo 3 da presente tese.
} 
administrativas que facilitassem o acesso do maior número possível de pessoas ao acervo, como a possibilidade de empréstimo domiciliar e ampliação do horário de funcionamento dos dispositivos. Para Adelpha Figueiredo, a preocupação com a expansão resulta na busca de parcerias com outras instituições sociais. A democratização da biblioteca para atender a todos sem exceção dialoga com o contexto compreendido pelos modernistas como propício aos processos simultâneos de fortalecimento dos movimentos sociais e profissionalização dos bibliotecários. Os futuros bibliotecários, agora profissionais, participariam da mobilização para lutar por ampliação de acesso à leitura como direito social..$^{91}$

Na sequência de seu discurso, Adelpha Figueiredo apresenta uma categorização objetiva sobre o que entende ser o leitor dentro da biblioteca e define como deveria agir o bibliotecário em relação a eles. Há uma inflexão significativa em relação ao nível do discurso de Moraes: Adelpha de Figueiredo se utiliza de um tom normativo em sua fala e se volta para o interior da biblioteca, onde acontecem as relações entre bibliotecário e leitor. Como já visto no item anterior, a visão de Moraes é ampliada, no sentido de suscitar nos alunos a ideia de que seu papel educativo e social extrapola os limites da biblioteca e corrobora com um projeto de sociedade, compartilhado por outros movimentos sociais em São Paulo, no Brasil e no mundo. Tratava-se de apresentar os desafios de se criar uma Escola frente aos embates políticos nas escalas local e nacional e às transformações societais em desenvolvimento não apenas na cidade de instalação da Escola, mas ao redor do mundo; transformações essas cujos impactos na produção e circulação da cultura não tardaram a aparecer.

Adelpha de Figueiredo define o primeiro tipo de leitor da seguinte maneira:

Os que leem para encher o tempo [...] Geralmente os deste grupo usam os livros como medicamento, para fugir a uma vida de tédio. Realmente não se interessam pela biblioteca, como o prova a leitura de sua escolha que gira em torno do livro de sensação, de literatura barata [...]. Não é deixando-os de lado que conseguiríamos mudar-lhes o gosto, mas tratando-os com solicitude. Esse grupo representa uma das falhas da nossa civilização. Tomando em consideração que a educação de muitos não vai além da escola primária, é de

\footnotetext{
${ }^{91}$ Vale lembrar que a primeira grande greve ocorrida em São Paulo datou de 1917 e teve como foco o parque industrial da cidade. Na década de 1920, na capital paulista, mas também em outros polos industriais, eclodem diversos movimentos paredistas. As bases de sustentação de Vargas - especialmente durante o Estado Novo consistem no investimento na educação e na cultura, associados a uma relação com os trabalhadores sem a mediação das instâncias democráticas (sindicatos autônomos, partidos políticos, casas legislativas) identificada pelos especialistas com o nome de "trabalhismo" cf. GOMES, A. C. A invenção do trabalhismo. Rio de Janeiro: FGV, 1988. Sobrevivendo ao fim do Estado Novo, sua força política se manteria ao longo de toda a década de 1950 (novamente, período de intensa industrialização) e apenas sofreria seu golpe fatal com a implementação do regime ditatorial de 1964. Não obstante as enormes diferenças de configuração entre os movimentos do início e fim do período, eles guardam em comum certas pautas, como a diminuição da jornada do trabalho, a melhoria das condições de emprego, formas de financiamento público para a construção de casas populares, rede de proteção aos doentes e inválidos, entre outras.
} 
admirar que esse grupo não seja ainda muito maior. É tarefa dos bibliotecários melhorar a situação, fazendo lentamente diminuir esse grupo, pelo ingresso dos indivíduos dele no grupo subsequente. (FIGUEIREDO, 1936, p. 1)

Adelpha de Figueiredo chama a atenção para a importância do vínculo entre leitor e biblioteca. Se, na visão tradicional, as bibliotecas eram um objeto de posse e estavam vinculadas aos seus proprietários por meio da "paixão pelos livros", com a biblioteca aberta a todos, a vinculação do leitor com a instituição passaria a fazer parte da responsabilidade do bibliotecário. Este, conforme pensa Adelpha de Figueiredo, deveria voltar sua atenção inicial ao leitor com o objetivo de identificar sua relação pessoal com os livros e, a partir daí, estabelecer uma estratégia de trabalho no fito de vincular o sujeito à instituição. Adelpha de Figueiredo reconhece que a indústria do livro está em projeto de expansão e isso facilita o acesso a obras para um público maior, numericamente falando. Ao mesmo tempo, indica que a biblioteca ganha novo papel diante da expansão do mercado editorial: ela é responsável por reconhecer este tipo de leitor atraído pela literatura "barata", de "sensação" e transportá-lo para o grupo dos familiarizados com a cultura legitimada como de boa qualidade por instâncias consagradoras oficialmente reconhecidas como tal (a escola, a universidade, a crítica literária expressa através da imprensa). Portanto, a biblioteca reteria um sentido de público como aquela instituição que possibilita o acesso a todos que dela se aproximarem, mas com a responsabilidade de pugnar pela conversão do leitor que enxerga a leitura exclusivamente como passatempo a outras formas de se relacionar com o livro:

Os que lêem para aprender. [...] Este é o grupo ideal, é por assim dizer, o sal
da terra. Seus componentes são os que procuram bons contatos e precisam
da certeza que a biblioteca os ajudará, que no bibliotecário encontrarão um
guia, um amigo. Propagar entre esses o desejo do trabalho nas bibliotecas é de
alto conselho, pois entre eles estão os apóstolos da ciência. Os que lêem para
adquirir uma informação de momento, com um objetivo determinado. [...] É
formado de elemento passageiro, que não compreende a organização da
biblioteca e nem os deveres do bibliotecário que para ele está apenas na
posição de servir, do cumprimento de um dever sem direitos. Desde que a
informação desejada lhe seja fornecida ele está satisfeito e retira-se sem pensar
em voltar. É neste campo que o bibliotecário precisa agir como missionário,
procurando converter o indivíduo à religião dos livros, atraí-lo às fontes
do saber, procurando fazê-lo ingressar no grupo anterior. Os que usam a
biblioteca pública como fonte para pesquisa de toda sorte. [...]. Este é o grupo
que dá menos trabalho. O mais que se lhe pode fazer é ver que o material
necessário lhe seja fornecido. (FIGUEIREDO, 1936, p. 1, grifo nosso)

Adelpha de Figueiredo fornece numerosas evidências sobre sua trajetória social e o peso de sua formação sobre a maneira como enxergava o papel da Biblioteconomia. Embora 
coincidentemente ela e Moraes tivessem se formado em instituições de matriz calvinista, apenas Adelpha de Figueiredo preservou um caráter fortemente religioso em sua visão de mundo, ao menos no que tange à atuação profissional. Pode-se lançar a hipótese de que o Colégio de Genebra, no qual Moraes viveu por alguns anos de sua juventude, tenha produzido uma experiência de sociabilidade relativamente mais secularizada que as salas de aula da Presbiteriana Mackenzie por onde passou Adelpha de Figueiredo ${ }^{92}$. Sejam quais forem os motivos, a intervenção de Adelpha de Figueiredo produz um entrelaçamento de um fundo religioso com o cientificismo ao afirmar que uma parcela dos leitores será o "sal da terra" 93 , por poderem se transformar em "apóstolos da ciência"94. Note-se aqui uma possível influência do calvinismo nos moldes consolidados na instituição presbiteriana de São Paulo, no diálogo com o que Weber (1999) identifica nas religiões de matriz calvinista: uma concepção de trabalho como beruf, vocábulo alemão que amalgama as noções de profissão (técnica), vocação (ética) e missão (propósito). O bibliotecário seria o sujeito que, dotado de técnicas modernas e portador de uma ascese do investimento na sua própria erudição, cumpre seu objetivo de identificar os diferentes perfis de leitores e de encaminhá-los para uma espécie de "salvação laicizada": a educação, tema que será desenvolvido ainda neste item. Com um pouco de ousadia, pode-se lançar a hipótese de que essa definição de bibliotecário mostra a fatura de composição ao negociar sua identidade entre os grupos positivista e católico, ambos fortemente representados na cena escolar paulistana (SAVIANI, 2013).

Adelpha de Figueiredo se apropria de expressões do vocabulário do primeiro grupo e de sua defesa da ciência, rejeitando a tradição católica de submeter a educação a propósitos

\footnotetext{
${ }^{92}$ Registre-se aqui, embora fujam aos objetivos do trabalho, o interesse em estudar como mulheres e homens seriam educados de forma diferente em colégios calvinistas e como as tradições nacionais do calvinismo também produziam matizes importantes no processo de socialização dos seus estudantes.

${ }_{93}$ A expressão remete ao Evangelho de Mateus, Capítulo 5, versículos 13 a 16, em uma passagem pronunciada por Jesus de Nazaré para se referir à responsabilidade de seus seguidores em relação às outras pessoas e se emprega a alegoria do sal para afirmar que os primeiros não deveriam se misturar com os últimos para lhes modificar o sabor, preservando suas características puras e sua integridade. Resulta, portanto, em uma afirmação de um caráter missionário do bibliotecário, portador de uma "verdade" a ser aceita pelos usuários. Note-se que o caráter missionário ganhou ares de estudo universitário (a "missiologia") nos finais do século XIX e se amalgamou ao discurso de superioridade racial dos europeus e norte-americanos em relação aos povos da África e da Ásia. (KOLLMAN, P. At the origins of mission and missiology: a study in the dynamics of religious language. Journal of the American Academy of Religion, Oxford: Oxford University Press, vol. 79, n. 2, p. 425-458, 2011). Como se verá ao longo destas e das próximas linhas, essa mistura entre a ideia de missão, cientificismo e afirmação da superioridade com base em saberes se repetirá ao longo de toda a aula de Adelpha de Figueiredo.

${ }^{94} \mathrm{~A}$ expressão "apóstolo da ciência" tem lastro no positivismo, mais especificamente na interpretação a ele conferida em terras brasileiras, a qual desembocou em curiosa aproximação entre o positivismo como a defesa da ciência e a adoção de uma nova religião. A peculiaridade estaria no fato de que, em suas obras iniciais, o fundador do positivismo (Augusto Comte) advogasse que o positivismo representaria exatamente a superação do estágio religioso da história da humanidade. Cf. COMTE, A. Cours de philosophie positive, 1877. Disponível em: https://bibdig.biblioteca.unesp.br/handle/10/28016. Acesso em: 03 mar. 2021.
} 
religiosos, mas o faz paradoxalmente, empregando ela própria tropos religiosos em profusão, como viria a fazer novamente, ao tratar da definição de bibliotecário:

O monge não é mais o tipo que nos convém. Para ter sucesso, um bibliotecário deve ser um "amante dos livros". [...]. Um verdadeiro amigo de livros não o é por possuir obras raras, coleções preciosas ou encadernações custosas, mas porque o exército de autores silenciosos, por ele guiado, difundirá luz e conhecimentos onde quer que esteja. O bibliotecário imbuído deste espírito, se achar tempo para ler, refletirá a sua leitura, sua eficiência dobrará e seus leitores terão nele um catálogo suplementar. (FIGUEIREDO, 1936, p. 2)

Assim como Moraes, Figueiredo apresenta uma perspectiva do bibliotecário como intelectual. Se para o primeiro o aspecto intelectual é parte constituinte do ser bibliotecário profissional, ou seja, está atrelado à sua identidade, para esta última a leitura e a reflexão constituem o arcabouço distintivo de sua eficiência no espaço profissional. Note-se que a eficiência aparece como resposta à expansão editorial que desafia o profissional a ser uma espécie de guia ("imbuído de [um] espírito") responsável por dar voz a "autores silenciosos", ou seja, a textos não consagrados - o que, por sua vez, o torna um educador que atua como guia ativo em processos de mediação junto ao leitor.

Depois de apresentar o que entendia ser o distintivo entre o bibliotecário tradicional e o profissional, Figueiredo discorre sobre o lugar das Escolas de Biblioteconomia na tessitura social que envolve, conforme já falamos anteriormente, mudanças de ordem societal que desembocam nas esferas social, educacional e cultural:

A complexidade das atividades de uma biblioteca, o progresso dos métodos educacionais, a necessidade da organização da cooperação da biblioteca com todo o mecanismo social de um povo, fizeram dos processos em vigor nas bibliotecas, uma ciência complexa, porém, suscetível de aplicação organizada e ao alcance dos estudiosos. A análise dessa complexidade trouxe-nos a constituição das partes básicas na organização e o aparecimento de disciplinas indispensáveis no preparo técnico de um bibliotecário. Daí nasceram as escolas de biblioteconomia visando o preparo técnico dos candidatos à carreira de bibliotecário. [...] visam essas escolas dar preparo técnico a candidatos que já tenham cultura bastante para dessa combinação nascerem os verdadeiros bibliotecários, mas, técnica e cultura, aliadas, darão os profissionais que procuramos para administrarem as nossas bibliotecas. (FIGUEIREDO, 1936, p. 2)

Moraes já havia chamado a atenção de seus alunos para a necessidade de compreender que os processos de urbanização, industrialização e expansão do mercado editorial demandariam uma análise cautelosa e situada sobre as relações históricas das bibliotecas para 
com a sociedade. Figueiredo, por sua vez, enfatiza o aparecimento das Escolas de biblioteconomia e ressalta que, naquele período, os "verdadeiros bibliotecários" eram possuidores de cultura e conhecimento técnico. Figueiredo apresenta as técnicas de organização e catalogação de acervos, como uma das variantes que complexificaram as "atividades de uma biblioteca"; em seguida relaciona o papel da biblioteca com a mudança do tipo de educação necessária para preparar os indivíduos para uma sociedade transformada pela ciência e pela técnica e que exigiam mudanças em sua política de formação de acervos; por exemplo:

\begin{abstract}
Antes que a habilidade de decifrar impresso se tornasse universal, os livros eram produzidos apenas para os eruditos. As bibliotecas, até o meado do século XIX continham, quase exclusivamente, livros sobre humanidades. $\mathrm{O}$ homem de leitura, que era sinônimo do culto ou educado, era aquele cuja leitura e interesses eram filosofias, religião, biografia ou literatura. [...] Havia, entretanto, já uma tentativa de produção científica e, debatendo-se entre essas duas correntes, letras e ciências, nasceu a biblioteca pública, numa época que coincidiu justamente com o aumento colossal de produção livresca, causada pelo desenvolvimento das novas forças econômico-sociais que começavam a despontar. [...] as bibliotecas de nossa época, não desconhecendo o valor de certas obras antigas, têm em mira o grande objetivo de todos os tempos: EDUCAR. Para isso, elas se obrigam a andar a par do desenvolvimento rápido das pesquisas científicas, renovando sempre suas coleções com o que houver de mais autorizado e novo em todos os ramos de atividade intelectual. Nós, bibliotecários, temos uma missão nova: pugnar pelo uso dos livros como instrumentos de educação, mas da verdadeira educação, de acordo com a época em que vivemos. (FIGUEIREDO, 1936, p. 4)
\end{abstract}

Sem mencionar os nomes dos assinantes do Manifesto da Escola Nova ${ }^{95}$, Figueiredo insere os alunos no mesmo embate promovido por este grupo em torno do que deveria ser a educação. Ao mesmo tempo em que eles afirmavam a necessidade de o país investir na formação especializada de seus educadores, de ampliar o acesso à escola pública e repensar seu currículo para direcioná-lo à alfabetização científica, Figueiredo pensa nas transformações da formação do bibliotecário, na facilitação do acesso às obras para o grande público e no perfil de coleção a ser construída pelo bibliotecário. Em suma, o bibliotecário é também um educador, no sentido do termo definido pelo grupo da Escola Nova. Entretanto, à diferença do que ocorreu no mesmo período na Universidade do Distrito Federal ${ }^{96}$, o posicionamento da

\footnotetext{
${ }^{95}$ Entre os quais se encontra: Fernando de Azevedo, Afrânio Peixoto, A. de Sampaio Doria, Anísio Teixeira, Lourenço Filho, Roquette Pinto, Júlio de Mesquita Filho, Noemy M. da Silveira, Cecília Meirelles, Armanda Álvaro Alberto.

${ }^{96}$ Anísio Teixeira, convocado a ser o reitor da Universidade do Distrito Federal, emplacou um modelo de universidade de acordo com seus princípios pedagógicos e por isso foi questionado por intelectuais reunidos em torno de Alceu Amoroso Lima. No final, Teixeira foi sacado da UDF e seu projeto foi completamente destruído.
} 
Escola de Biblioteconomia, apresentado por Adelpha de Figueiredo, não encontrou resistência, fato que pode ser explicado por um deslocamento dos polos do debate na cidade de São Paulo em relação ao restante do país. A sinergia de forças entre políticos locais, intelectuais modernistas e os princípios enunciados pela Escola de Biblioteconomia ${ }^{97}$ constituía uma singularidade da paisagem paulista e era improvável em praças como Rio de Janeiro ou Minas Gerais, onde, por motivos distintos, a educação católica possuía uma articulação política relativamente mais forte. Por outro lado, contudo, grupos de Minas Gerais, Bahia e Rio Grande do Sul demonstraram simpatia pela bandeira hasteada em torno do projeto de biblioteconomia dirigido por Rubens Borba de Moraes ${ }^{98}$.

\subsection{Rubens Borba de Moraes, professor na Escola de Biblioteconomia: entre a técnica e a cultura}

O curso de "Arte do Livro" foi ministrado em 25 aulas, entre 22 de abril de 1937 e 24 de fevereiro de 1938, transcritas por J. Eduardo Oliveira de Barros. A justificativa para a existência do curso é fornecida logo na primeira aula e pauta os interesses e objetivos que Moraes pretende alcançar:

Muita gente julga que para o bibliotecário não há necessidade de conhecimentos sólidos de história do livro. É um erro, pois que o bibliotecário não possui somente uma técnica, isto é, um conhecimento com aplicação imediata, mas deve possuir uma cultura mais desenvolvida e desinteressada, isto é, que não tenha aplicação imediata e diária. Urge que se faça uma distinção entre cultura e técnica. O bibliotecário deve ser uma pessoa que possua estes dois elementos. (MORAES, 1937, p. 1, grifo nosso)

Como pretendemos demonstrar ao longo deste item, a superação da dicotomia entre técnica e cultura se dá, no caso desta matéria do curso, através da apresentação das técnicas de preparação do livro, visto sob a perspectiva da chave de leitura da sociedade que produziu essa forma de registro. Moraes pretende romper a separação historicamente estabelecida na atividade biblioteconômica entre pensamento crítico e rotina de organização de bibliotecas, entre o agir (homo faber) e o refletir sobre a ação (homo sapiens) (BACHELARD, 1938) e o bibliotecário como profissional que assume a posição de protagonista cultural (PERROTTI; PIERUCCINI, 2008), superando a dualidade técnica versus cultura. Com tal ideia, Moraes (1937) equipara a

\footnotetext{
${ }^{97}$ Mas não apenas por ela. Vale lembrar que o brasão escolhido para a recém-criada Universidade de São Paulo incluía o dístico latim "Sciencia vinces", ou "A ciência vence", em português.

${ }^{98}$ Isso será tema desenvolvido no capítulo 5 da presente tese.
} 
condição de bibliotecário à condição do filólogo ou do historiador, isto é, de um estudioso sobre o passado, compreendido em sua relação dialética com o presente (MORAES, 1929) ${ }^{99}$, cuja missão seria possibilitar contatos com a inteligibilidade da forma de pensar e sentir das sociedades antigas no presente.

A realização desse intuito conecta o presente ao passado, desvelando continuidades dessas distintas camadas sobrepostas e atuantes umas sobre as outras. O formato do curso e sua atenção às tecnologias empregadas na fabricação do livro, à sua materialidade, aos tipos de letra e de outros elementos textuais apontam na direção de um método próprio de trabalho, a ser constantemente reafirmados e aprimorados pelos bibliotecários em formação na escola e pelas gerações posteriores. Ora, o filólogo trabalha com o vocabulário e a etimologia dos vocábulos para desenterrar-lhe os significados contidos em sua trajetória ao longo do tempo. Por sua vez, o historiador desenvolve métodos de leitura da documentação para datá-la com precisão e fazêla dialogar com as perguntas que o inquieta. De modo similar, na visão de Moraes, o bibliotecário se torna responsável por tratar o livro como seu objeto de estudo, não apenas em termos de conteúdo, mas também em sua própria fatura.

Em diálogo com a reflexão da historiografia francesa sobre a categoria epistêmica “documento/monumento" (LE GOFF, 1990), pode-se descrever o esforço de Moraes ao longo do seu curso em enxergar nas diversas formas históricas adotadas pelo livro o objeto que faz recordar, que perpetua as sociedades do passado nos aspectos que decide registrar voluntariamente e, muitas vezes, em perspectivas involuntariamente abertas ao conhecimento das gerações posteriores, mas ambas com caráter de prova aberta à interpretação e reavaliação pelos pares. Para tamanha pretensão, Moraes dispõe de um arcabouço teórico constituído pelas reflexões mais atualizadas da Antropologia de sua época, como revela o trecho a seguir:

Iniciando-se hoje o estudo da matéria propriamente dita, vamos examinar as origens da escrita de uma maneira muito esquemática. A necessidade de transmitir o pensamento pela palavra escrita não constitui uma necessidade para certas civilizações. Quando eu digo "civilização" e quando digo "cultura", emprego tais expressões no sentido "etnográfico", isto é, sem estabelecer comparações entre elas, sem sugerir ideia de progresso. Cultura e civilização são dois termos que não têm sentido comparativo, quando aqui empregadas. Assim, pois, houve culturas que não sentiram esta necessidade de transmitir o pensamento por meio da escrita, que nos parece natural, quase instintivo. (MORAES, 1937, p. 6)

\footnotetext{
${ }^{99}$ Cf. MORAES, R. B. de. Lar Brasileiro. Revista de Antropofagia, São Paulo, ano 1, n. 9, p. 3, jan. 1929. Disponível em: https://digital.bbm.usp.br/bitstream/bbm/7064/10/Anno.1_n.09_45000033273.pdf. Acesso em: 03 mar. 2020.
} 
Moraes logra deter-se sobre diversas sociedades do mundo antigo com especial atenção para aquelas cuja escrita alfabética contribuiu para nossa forma atual, porém, também reserva linhas para outras formas de escrita mais ou menos distantes da Ocidental, como a cuneiforme (da Babilônia), de onde se acredita que os fenícios partiram para desenvolver a ideia de alfabeto, ou ainda a ideográfica (China antiga). Neste estudo de longo fôlego, Moraes demonstra sintonia com a antropologia iniciada por Franz Boas e propagada no Brasil por nomes como o de Gilberto Freyre; ambos a alertarem para a necessidade da relativização cultural - isto é, negar a existência de uma hierarquia entre as sociedades. Vale lembrar que neste período ainda estava em vigor o debate entre os termos "civilização" e "cultura", os quais podem ser compreendidos pelo prisma definido por Norbert Elias (1990): o primeiro indica uma tentativa de compreender a espécie humana naquilo que ela teria de unidade e indica um sentido dentro da heterogeneidade, ao apontar o que seria posterior - isto é, mais civilizado - e o que seria anterior, tido como mais atrasado, arcaico. Cultura, ao contrário, elevaria as manifestações de uma determinada sociedade à condição de categoria singular, idiossincrática, às quais não poderiam ser aplicados critérios de classificação externos à própria sociedade que as produziu.

É pertinente aos objetivos da presente tese especular sobre o que significaria admitir, logo no início do curso, que nem todas as culturas sentem a necessidade de uso da palavra escrita em meio a uma experiência urbana que acolhe diversas culturas entre as quais várias também se pautavam pela oralidade, por tradição e por falta de opção ${ }^{100}$. Embora Moraes não comente esse paralelismo, pode-se deduzir que seu raciocínio autoriza a concluir que as pessoas nessa condição - para as quais também se pensava a biblioteca, como demonstrado pelo projeto de bibliotecas Parque e de bibliotecas nos bairros operários - deveriam ser tratadas em pé de igualdade em relação às outras. Para se ter uma ideia do que isso representa dentro dessa época, não custa lembrar que, até 1930, o país e, de forma especial, o que hoje conhecemos por Sudeste e Sul, haviam sido objetos de uma política racial de "embranquecimento" da população com o fito de "europeizá-la" e que o modelo de cultura estabelecido nas paragens de Piratininga era o francês, visceralmente constituído sob o império da cultura escrita. Se, por um lado, o argumento de Moraes adere ao interesse de Mário de Andrade pelo folclore ${ }^{101}$ e pela cultura

\footnotetext{
${ }^{100}$ Os Censos de 1920 e 1940 indicavam, respectivamente, 65\% e 56\% da população analfabeta, na média nacional. Não foram encontrados índices específicos para a cidade de São Paulo nos anos 1930; na falta destes, pode-se apontar um estudo comparativo entre os estados de São Paulo, Paraná e Rio Grande do Norte capaz de indicar um índice de $70 \%$ de analfabetismo no território paulista em 1920 (um pouco acima da média nacional para o período). Cf. PINTO, J. M. et al. Um olhar sobre os indicadores de analfabetismo no Brasil. Revista Brasileira de Estudos

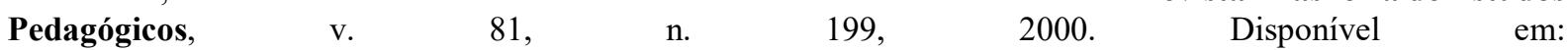
http://www.rbep.inep.gov.br/ojs3/index.php/rbep/article/view/1340. Acesso em: 03 mar. 2020.

${ }^{101}$ Em 1937, Moraes participou do II Congresso de População, etnografia e folclore em Paris, juntamente com Sérgio Milliet, representando o Departamento de Cultura.
} 
política, até a gradual percepção de Monteiro Lobato sobre as raízes sociais (isto é, não biológicas) dos vícios do caboclo brasileiro, por outro lado se bate contra uma linhagem de pensamento constituído por nomes como o de Nina Rodrigues, Oliveira Vianna e outros pensadores que enxergam saídas autoritárias para os problemas nacionais e que desconsideram a diversidade cultural do país.

Nas ruas, Moraes - como todos os outros paulistas - encontravam manifestações integralistas em favor de Plínio Salgado e sua crença em uma pretensa superioridade do elemento europeu sobre todos os demais legados para a cultura brasileira. Nos livros didáticos de história mais vendidos no período, Jônathas Serrano (professor do D. Pedro II) erigia o catolicismo português como o baluarte da cultura brasileira. Enfim, um recuo no tempo permite enxergar o sentido histórico do posicionamento de Moraes, devolver-lhe o sentido avançado que possuía e o que projetava como função social do bibliotecário, no embate com outras vertentes interpretativas sobre o Brasil e as consequências políticas e culturais dessas alternativas etnocêntricas.

Em coerência com o projeto estabelecido acima, RBM percorre uma longa via pelo mundo antigo e dedica toda a terceira aula para uma apresentação sobre o papiro; aborda as diferentes qualidades, as formas de se registrar o texto sobre ele e as tipografias distintas empregadas por egípcios, gregos e romanos. Percorre a geografia dos papiros preservados até o presente e inicia uma vertente inovadora ao tratar do livro como objeto de comércio e da importância deste aspecto em dois sentidos: a) compreender como se dava o comércio do livro permite entender melhor sua história, enxergar os agentes envolvidos em sua produção, circulação e preservação; b) em seguida, também é possível compreender as relações mercantis como formas privilegiadas de trocas culturais estabelecidas em torno do objeto livro, para além do ato de compra e venda; são dois ou mais mundos que se tocam. Este raciocínio é carregado de significados para o presente, como demonstra a passagem abaixo:

O comércio do papiro era feito, no Egito antigo, em larga escala. Ao tempo dos Ptolomeus, parece que o papiro foi um dos produtos de maior exportação da época e alguns historiadores sustentam que chegou a constituir monopólio do Estado. Esta é, porém, uma questão muito controvertida. [...] O curioso, porém, é que os romanos importavam o papiro bruto e depois preparavam-no para ser revendido. Procediam, portanto, exatamente como nossos industriais que importam um produto bruto, manufaturam-no e revendem-no. É por este motivo que encontramos nos papiros antigos certas referências às "Carta Claudia" e "Carta Augusta"; eram marcas feitas no tempo de Claudio e de Augusto. (MORAES, 1937, p. 16) 
A dinastia ptolomaica é aquela que governa o Egito após a morte de Alexandre o Grande e a divisão de seu império entre seus generais, cabendo ao primeiro Ptolomeu o domínio da região do rio Nilo. Ele e seus descendentes homônimos promovem a transferência da capital para a recém-criada cidade de Alexandria, onde havia uma biblioteca em torno da qual se desenvolvia uma política, estendida a todo Egito, de promover o encontro entre a cultura grega clássica e a nativa. Diferentemente dos faraós do antanho, portanto, estimulavam o comércio e as trocas culturais com outros povos, mormente com aquele estabelecido na península itálica e que se encontrava, neste período, em processo de expansão militar e comercial. Até que o pacto político amoroso entre Cleópatra VII e Marco Antonio fizesse água, em 30 a. C., e seu rival Otaviano Augusto reduzisse o Império Ptolomaico a uma província do Império Romano.

Como se verá ao longo deste item, esmiuçar o comércio sobre o livro - neste caso em específico, redigido sob o suporte do papiro - é uma forma de comprovar seu potencial aglutinador; realçando a sensibilidade dos bibliotecários para a função social que o hábito da leitura exerce antes mesmo de chegar a termo. Dito de outra forma, o exercício exige que a atenção à materialidade do livro seja estimulada no cotidiano de sua atividade profissional e de sua reflexão acadêmica, antecipando, portanto, a direção que a história cultural de Chartier indicará várias décadas depois, ao se deter, por exemplo, na materialidade da "ordem dos livros".

Também é possível observar como o papiro serve como instrumento de conexão, na sequência narrativa das aulas, entre as culturas egípcia, grega e romana. Dá mais importância aos gregos do que aos romanos, classificados como meros copiadores dos feitos helênicos, mas valorizados em sua avidez pela leitura e pelo apoio aos escritores ${ }^{102}$. Outra herança romana identificada por Moraes no cotidiano brasileiro de seu tempo era a convergência das funções de editor/livreiro, cabendo ao editor não apenas providenciar as cópias que desejava pôr à venda, como anunciá-las e fazê-las conhecidas, através de sessões públicas de leitura e divulgação de seu "catálogo". Se retomarmos a divisa croceana de que "toda história é história do presente", o tema dos direitos autorais emerge por contraste em comparação com o arranjo promovido

\footnotetext{
102“Sabemos que os romanos não tinham cultura própria, mas que se limitavam a copiar aquilo que já tinha sido feito pelos gregos. Em Roma, existia um intenso comércio de livros, o que é facilmente compreensível se nos lembrarmos dos vultos notáveis, em todos os ramos do conhecimentos humano, que existiram em Roma. [...] Naquele tempo não existiam os direitos autorais e o editor nada pagava ao escritor para editar-lhe a obra. $\mathrm{O}$ editor tirava as cópias pedidas, procedia à venda das mesmas e nada pagava ao escritor. Quando o autor queria receber alguma coisa pelo seu trabalho, dirigia-se a um mecenas e este, a troco de uma dedicatória ou de um discurso laudatório, no início da obra, gratificava o escritor. Este sistema perdurou muitos anos e na história do livro vimos encontrar a existência dos direitos autorais somente posteriormente, no século XVIII, pois que até então os autores viviam do mecenato. No Brasil, não faz muitos anos que se paga alguma coisa aos que escrevem." (MORAES, 1937, p. 18).
} 
pelos romanos - ou talvez devêssemos dizer, a continuidade, dada a errática situação dos direitos autorais na história editorial brasileira.

A preocupação em aproximar esses tempos distantes do cotidiano dos estudantes é uma estratégia retórica comum a diversos pontos do livro. Ao descrever a biblioteca romana, a qual se mirava no exemplo da Biblioteca de Alexandria, Moraes retoma aspectos como o salário dos bibliotecários romanos, convertido em valores de sua época para 60:000\$000 ${ }^{103}$, o fato de que as bibliotecas romanas permitiam o empréstimo a domicílio ou de que não era considerado necessário manter o silêncio no recinto. Também é das bibliotecas romanas, ou mais precisamente a de Alexandria, que surge o costume de se produzir um catálogo das obras contidas em seu interior, para informação dos usuários e da administração. A descrição das bibliotecas romanas parece trazer para o tempo da aula anseios que Moraes desejava ver realizados nas instituições e nos bibliotecários de seu próprio presente, como volta a ocorrer quando comenta o apreço que os romanos ricos possuíam pela formação de coleções gigantescas.

Este "snobismo" dos romanos, relativamente às bibliotecas, é um fenômeno humano que perdura até nossos dias e assim é que vemos milionários fazerem questão de terem bibliotecas completas, cujos livros, porém, não leem. Todo romano rico, como já disse, possuía bibliotecas, e Luciano e Marcial criticavam os romanos que, apesar de possuírem bibliotecas tinham menos cultura que seus escravos bibliotecários. (MORAES, 1937, p. 20)

Moraes provavelmente se refere a Luciano de Samósata, autor de obras satíricas sobre os costumes romanos que foram publicadas, principalmente, entre 161 e 180, e Marcus Valerio Marcial, sobre o qual se sabe muito pouco, exceto que provavelmente viveu entre 40 e 104 de nossa era. Para além da erudição histórica, a passagem atesta a diferença já descrita em outras passagens da presente tese entre o bibliófilo e o bibliotecário. Se o primeiro estanca sua verve pelos livros no ato da posse, deste último se exige a tarefa de conhecê-los ou, no mínimo, saber atribuir-lhes valor e possibilidades de viagens fundamentais ao mundo essencial do conhecimento; ao decidir incluir este ponto em sua aula, Moraes reforça que essa era sua expectativa para seus estudantes, no presente. Assim como no passado romano, os bibliotecários formados pela Escola se fariam valer pelo valor da cultura acumulada no contato com os livros, independentemente de qual fosse sua posição circunstancial na hierarquia das organizações onde trabalhassem. Assim como no passado romano, os manuscritos poderiam

\footnotetext{
${ }^{103}$ De acordo com o Acervo do $O$ Estado de S. Paulo, este valor equivaleria, em termos atuais, ao equivalente a 2 mil exemplares do diário, ou seja, $\mathrm{R} \$ 10$ mil.
} 
assumir valores astronômicos para sua época e eram buscados por sua raridade, mas isso não impediria que o verdadeiro valor de um livro estivesse acessível ao bibliotecário ou àqueles que se utilizassem de seus serviços.

Curiosamente, a descrição das bibliotecas medievais oferece uma visão desse período como "Idade das Trevas", cunhada durante o Renascimento e sobrevivente, na historiografia, até os trabalhos inovadores de Marc Bloch e outros autores publicados nos Annales $^{104}$. Ao contrário dessa visão tradicional, as bibliotecas conventuais no medievo são vistas como um centro de saber, onde copistas desenvolveram técnicas de reprodução dos textos e aprimoramento da tipografia, com a inovação proposta pelas iluminuras e pela fonte carolina. Entre os séculos XII e XIII, surgem as primeiras universidades, abordadas no texto de Moraes sob o aspecto da intensificação de uma rede de circulação dessas obras a unir partes da Europa, Ásia e África, prefiguração da mundialização dos textos que se instalaria com força inédita a partir do século XIX (tema das aulas finais do curso), como demonstra a passagem abaixo:

Os copistas estavam organizados em corporações que, na [I]dade [M]édia, tiveram papel importantíssimo no desenvolvimento do livro, sob todos os pontos de vista, inclusive o comercial. Podemos dizer que antes das universidades ainda não existia aquilo que chamamos o comércio de livro organizado. A princípio tal comércio estava adstrito às universidades, a que estavam ligados os copistas, os encadernadores, os iluminadores, os rubricadores. Eram as universidades que expediam autorização para cópia de texto, bem como que fiscalizavam esta cópia. As universidades intervinham na revisão e cópia das obras que os livreiros faziam e vendiam, e esta venda era feita em conformidade com regulamentos muito severos. [...] No século $\mathrm{XV}$, o comércio do livro adquire outro aspecto e desenvolvimento muito maior, pois que o livro passa a ser objeto de comércio como qualquer outro. Isto se explica pela circunstância de ter surgido, neste século, uma nova classe: a dos burgueses. O comércio veio abrir as portas da fortuna a muitos indivíduos que vieram a constituir uma nova classe social à qual não interessava tanto a literatura sagrada, o livro da literatura cristã, mas que apreciava imensamente o livro comum, o romance, o livro de versos, etc. Isso acarretou o grande desenvolvimento da literatura comum. Nos séculos XIV e $\mathrm{XV}$, começam a aparecer as grandes obras em língua nacional. A burguesia desde logo se interessou pelos livros jurídicos, pelo livro prático, de ensinamentos úteis como livros de receitas médicas, de botânica, etc. Esta procura de livros sobre assuntos novos, para a qual tanto contribuiu a burguesia, teve como consequência trazer um grande desenvolvimento para $o$ comércio do livro. (MORAES, 1937, p. 44)

\footnotetext{
${ }^{104}$ Moraes menciona diversos manuais franceses de biblioteconomia na sua bibliografia, mas é impossível ter acesso a eles para verificar se estes teriam tido contato com alguma obra de Bloch para comprovar a linhagem. Neste caso, apenas a simultaneidade entre M. Bloch - cofundador do periódico Annales d'histoire écnomique et sociale, onde trabalhos inovadores sobre a Idade Média foram publicados - e Rubens Borba de Moraes não é suficiente para atestar alguma relação intertextual entre ambos.
} 
Diversificação das temáticas abordadas pelos livros, protagonismo de uma nova fração social urbana, que procura uma literatura em sintonia com suas novas formas de subjetividade. Várias das características que Moraes identifica no Brasil de seu tempo presente podem ser cotejadas a outros períodos históricos, como o da transição ocorrida entre os séculos XIV e XVI, grosso modo. Em sua viagem pela odisseia do livro, Moraes conduz seus estudantes através de suas aulas a construírem, com a ajuda do recuo no tempo, uma sensibilidade para a forma como se distribuíam os papéis de produção, divulgação e mediação do uso do livro que, naquele momento do curso, se esperava que fossem assumidos pelos bibliotecários formados nessa nova proposta que, ao menos em termos de Brasil, Moraes propunha de forma pioneira ${ }^{105}$. A menção aos copistas, iluminadores, mercadores de livro comum - influentes também na formatação dos gostos literários sob o ângulo da oferta de novos livros, em diálogo com a demanda oriunda de uma classe burguesa ávida por leitura - mostra como o sucesso da prática da leitura depende de uma série de profissionais do livro cuja formação e ramo de atuação se especializaria progressivamente durante as Idades Moderna e Contemporânea, em um processo histórico de longa duração cuja compreensão era fundamental para que os bibliotecários em formação no curso de Moraes compreendessem a si mesmos, e às expectativas que deveriam se preocupar em atender.

A comparação com o período do Renascimento permite enxergar um período que traz uma virtude fundamental para as pretensões de RBM e do grupo dos modernistas: a facilitação do acesso aos livros, promovida nesse período em relação à Idade Média. O aumento no acesso à leitura conduz as sociedades renascentistas europeias a criar novas formas de se relacionar com o livro, com a valorização da individualidade do leitor como determinante do que merece circular. O interesse renascentista pelo livro de ciências ou pelos gêneros literários que abordam sentimentos, dilemas e dramas da vida terrena é, em seu conjunto, formas de valorizar as transformações que tornam o mundo mais complexo, mais próximo das formas atuais de trocas econômicas (chamadas genericamente de "capitalismo") e dos modos de o indivíduo se pensar e se sentir como parte da sociedade, dotado de livre arbítrio e de direitos de exercer sua subjetividade.

\footnotetext{
${ }^{105}$ Em outubro de 1945, Luiz Washington escreve um artigo no Correio Paulistano no qual declara: “A biblioteca [..] é um ser orgânico que carece de sol e de ar para subsistir. E hoje negam-lhe tais elementos. O problema bibliotecário, no Brasil, não está na fundação de novas casas de leitura, mas no seu melhor aproveitamento. Esta é a opinião dos nossos mais abalizados técnicos no assunto [...] e é o motivo condutor dos escritos e palestras de Rubens Borba de Moraes. [...] o interesse está em que seus livros sejam verdadeiramente lidos, só resta uma solução - o processo circulatório. Cf. WASHINGTON, L. Posição do bibliotecário. Correio Paulistano, São Paulo, ano 92, ed. 27.411, p. 4, 03 ago. 1945. Disponível em: http://memoria.bn.br/DocReader/090972_09/24530. Acesso em: 03 mar. 2020.
} 
Para Moraes, conhecer o tipo ideal (no sentido weberiano do termo) de bibliotecário em afinidade eletiva com este período histórico especial, que marca a virada para o que ficou reconhecido como Modernidade, em oposição à Antiguidade e à Idade Média, é fundamental para fazê-lo dialogar com os desafios vivenciados em seu presente e, por essa razão, decide apresentar aos seus estudantes a figura histórica de Petrarca. Aqui conhecido como o "pai do Renascimento" pelas inovações de sua produção literária, tais como escrever em língua vernácula e abordar as delícias e dilemas das paixões amorosas, Petrarca é apresentado no curso sob outra faceta: a do bibliófilo/bibliotecário, embora esta última perspectiva tenha sido subitamente interrompida pela morte precoce do italiano.

É significativo que o poeta/bibliotecário tenha sido apresentado como alguém que reconhecia com igual valor as obras de Santo Agostinho e de Cícero (prova de um espírito universal que dialogava com a herança greco-romana sem olvidar-se das preocupações medievais), que percorreu muitas das principais regiões da Europa em termos de produção artística e cultural (Península Itálica, França e Países Baixos), conhecia profundamente o latim e financiou a tradução de obras em grego para esta língua, a fim de que pudesse conhecê-las, além de adquirir muitos livros para sua coleção pessoal e arquitetar, ao final de sua vida, a doação de todos eles para a formação de uma biblioteca pública em Veneza. Ainda que este sonho não tenha logrado bom êxito pelas razões já expostas, o fato de isso ser concebido como plano o torna, aos olhos de Moraes e da bibliografia que o acompanha, o "pai das bibliotecas".

Em termos de legitimidade acadêmica e cultural, a aposta de Moraes é alta: deseja posicionar a importância do bibliotecário para a cultura ao mesmo pé do poeta e do humanista, indexando o mesmo "pai” para as três funções sociais. Pragmático, Moraes também adverte seus ouvintes sobre a relação entre as bibliotecas e o poder político, ao destacar como exemplo de bibliotecas renascentistas a biblioteca pública do Convento de São Marcos, patrocinada pela família Médici, e a biblioteca do Vaticano, enriquecida pelo trabalho de papas como Nicolau $\mathrm{V}$, descrito como "erudito e bibliotecário capaz e (sic) sentia tal paixão pelo livro que empregou toda sua fortuna pessoal na aquisição de livros” (MORAES, 1937, p. 47).

A arte do livro é outro objeto central do curso de Moraes, com aulas inteiramente dedicadas à descrição da trajetória das tecnologias envolvendo não só o fabrico do papel, seu emprego em diferentes técnicas de impressão, mas também no formato dos livros. Os in-quartos do início da impressão são substituídos por formatos menores, como os do in-oitavo, e surgem inovações de projeto gráfico, como a criação de uma capa e da lombada do livro (século XVIII) para indicar título e autor. As técnicas de ilustração também variam com o passar do tempo, adotando-se a "telha doce" e, posteriormente, a litografia, isto é, literalmente, o desenho sobre 
pedra. Técnicas mais arcaicas como a xilogravura são substituídas, no século XIX, pela impressão e inovações das técnicas tipográficas, como as de Plantin, esmiuçadas por Moraes. A "arte do livro", como já sinalizado pelo título da matéria, é objeto da atenção de Moraes especialmente no final do curso, quando as formas de se produzir livros se diversificam, complexificando-se, e também é um período para o qual há mais evidências históricas a serem analisadas. O panorama histórico chega ao fim com a análise do século XIX, sobre o qual algo muito semelhante ao presente de RBM pode ser dito:

É evidente que o livro do século XIX é muito semelhante ao do século atual. A biblioteca do século XIX, bem como o comércio e a fabricação do livro, já eram quase como no século em que estamos. O que caracteriza o século XIX sob o ponto de vista que nos interessa é o extraordinário desenvolvimento da produção literária, então verificado. Podemos dizer que a partir de 1880 o livro toma um desenvolvimento assombroso e a produção literária atinge cifras fantásticas. [...] Conhecer os grandes editores do século XIX é conhecer os pais das grandes casas editoras de hoje. As bibliotecas também tiveram um desenvolvimento enorme, que começou logo no início do século, com a $[R]$ evolução $[F]$ rancesa, quando se deu a nacionalização das bibliotecas particulares. [...] Finalmente não quero deixar de lembrar a influência enorme que teve o 'Manuel du libraire' publicado por Brunet. Brunet introduz na bibliografia uma classificação [com] uma orientação histórica e uma descrição de exemplares, como teremos oportunidade (de) ver futuramente, em outro curso. (MORAES, 1938, p. 78)

A comparação do mercado do livro de seu tempo com o do século XX, e a referência a Jacques-Charles Brunet (1780-1867), símbolo do retorno dos bibliógrafos à classificação de livros raros metódica, precisa e instrutiva (ARAÚJO; REIS, 2016) e realista (OTLET, 2018), indica uma aposta de Moraes em chamar a atenção dos alunos para a necessidade de se conhecer com profundidade o passado do campo, de suas dinâmicas e objetos. Nesse sentido, o resgate histórico, construído ao longo de suas aulas, conduz os estudantes a repensarem suas práticas cotidianas, a partir dos sentidos social e histórico do livro e de sua profissão, que apesar das correlações de tempo, não nasceram e nem se encerrarão com as aulas de "Catalogação" e "História do Livro".

\subsection{Aprendizados de um processo}

Após um sucesso considerável no número de inscrições de suas três primeiras turmas, a Escola de Biblioteconomia sofreu um duro golpe que significou uma interrupção de suas atividades até que o projeto fosse retomado pela Escola Livre de Sociologia e Política de São 
Paulo, alguns anos depois. As razões do ataque à primeira instituição formadora de bibliotecários em São Paulo carecem de maiores e aprofundados estudos. No entanto, tentaremos neste item, por meio da análise do Processo $n^{\circ}$ 68.268/1938, da Prefeitura do Município de São Paulo, extrair elementos para a reflexão biblioteconômica, sobre o que significou amparar-se no poder local, como principal agente da regulação e incentivo da formação de bibliotecários e de como as disputas local versus nacional implicara, entre outros resultados, em certa dificuldade em garantir a continuidade da formação e, posteriormente, o crescimento e a autonomia do campo social, frente às tentativas de ingerência dos ocupantes do comando da burocracia.

Os eventos ligados a este processo têm sua raiz na Constituição outorgada ao país em 10 de novembro de 1937, em decorrência do golpe de Estado que dá início ao Estado Novo ${ }^{106}$. Redigida por Francisco Campos, pensador e jurista alinhado em seus escritos com a intenção de privilegiar a organização e o controle da vida nacional sob o poder central, ainda que em detrimento do poder nacional, a nova Carta Magna conferiu um caráter autoritário e centralizador de todas as decisões na figura do chefe do Executivo nacional ${ }^{107}$, posto que caberia a Getúlio Vargas, como as tropas postas na rua nos dias seguintes ao golpe não deixariam dúvidas.

No bojo desse espírito controlador e normatizador dos diferentes aspectos da vida pública, o art. 159 da Constituição de 10 de novembro, de 1937, estabelece as condições para acúmulo de vencimentos entre os funcionários públicos: “Art 159 - É vedada a acumulação de cargos públicos remunerados da União, dos Estados e dos Municípios." Trata-se, como se vê, de uma proibição pura e simples, sem concessões à complexidade das situações na administração pública brasileira. Talvez por isso, precisou ser complementado pelo Decreto-lei $\mathrm{n}^{\mathrm{o}} 24$, de 29 de novembro de 1937, o qual confirma e tornam mais precisas as disposições do texto constitucional:

\footnotetext{
${ }^{106}$ Nesta data, Getúlio Vargas faz divulgar um plano falso em que comunistas nacionais apoiados pelos soviéticos tentariam tomar o poder no Brasil; o "Plano Cohen". O objetivo do plano era criar um clima que justificasse o fechamento de todas as casas legislativas e, principalmente, interrompesse o processo eleitoral que escolheria o sucessor do próprio Getúlio Vargas, visto que ele estaria impedido de concorrer à eleição pela Constituição de 1934. Coerentemente a este intuito, o primeiro gesto de Vargas é outorgar uma nova Constituição, que estabelecia a obrigatoriedade - mesmo depois de já posta em prática - de passar por um plebiscito avaliativo (art. 187), nunca realizado.

${ }^{107}$ Além dos óbvios exemplos das Constituições vigentes na Alemanha, Itália e Portugal, Francisco Campos inspirou-se no texto constitucional da Polônia, outro país no cinturão de regimes de extrema-direita. Por isso, a Constituição de 1937 ganhou o apelido de "polaca", termo que em linguagem chula da época também podia se referir a profissionais do sexo e assim poderia exprimir, dentro da mentalidade do período, a ideia de um texto "prostituído", "imoral".
} 
Art. $1^{\circ}$ É vedada a acumulação de funções ou cargos públicos remunerados da União, dos Estados ou Municípios, bem como de uma e outra dessas entidades, qualquer que seja a forma da remuneração. A proibição do artigo 159 da Constituição estende-se aos empregados de caixas econômicas, do Banco do Brasil, Lloyd Brasileiro, Instituto Nacional de Previdência e institutos e caixas de aposentadorias e pensões.

Art. $2^{\circ} \mathrm{O}$ funcionário ou empregado civil, ou o militar, que na data desta lei estiver acumulando funções ou cargos públicos remunerados, deverá optar dentro de trinta dias, a partir da data da publicação desta lei, por um só cargo ou função. [...]

Art. $5^{\circ}$ Não se compreende na proibição dos artigos precedentes o recebimento de ajudas de custo, diárias, representação, gratificações por serviços extraordinários e gratificações de função legais ou regulamentares. [...]

Art. $9^{\circ}$ Aos funcionários que além de vencimentos fixos percebam quotas, percentagens ou gratificações é fixado o limite máximo de cinco contos de réis mensais para a totalidade desses proventos.

Art. 10. O Ministro da Justiça e Negócios Interiores providenciará para que o texto deste decreto-lei seja transmitido por via telegráfica aos Governos dos Estados, afim de ser publicado nos respectivos órgãos oficiais. (BRASIL, 1937, p. 23672)

A lei define a amplitude exata da aplicação do princípio constitucional, estabelece seus limites, prevendo as exceções a serem permitidas, e exige a comunicação oficial às administrações estaduais, para que se adequem à nova condição. Atinge, portanto, todo o funcionalismo público, mas especialmente aqueles que acumulassem alguma gratificação ou cargo. Esses eram os casos de Rubens Borba de Moraes e Adelpha de Figueiredo, que receberam, até junho de $1938,500 \$ 000^{108}$ mensais pela docência na Escola (o texto não menciona nenhuma gratificação extra a Moraes, por estar na condição de diretor), conforme informação oficiada pelo próprio $\mathrm{RBM}^{109}$, a pedido de seu superior imediato, o Diretor do Departamento de Cultura, Francisco Pati ${ }^{110}$.

Os riscos inerentes à situação levaram os membros do poder estadual a se movimentarem conforme seus interesses e receios. Como é frequente ocorrer na administração

\footnotetext{
${ }^{108}$ Considerando as singularidades históricas que tornam difícil atualizar os valores de um período histórico para o presente, pode-se utilizar como instrumento de comparação o número de exemplares de jornal que poderiam ser adquiridos com essa quantia. Em setembro de 1938, data do ofício de Rubens, 500\$000 compravam 1666 exemplares do Estado de S. Paulo, o que equivale a R\$ 8300 reais em 2021, aproximadamente.

${ }^{109}$ Os dados conferem com o que encontramos no "Livro caixa da Escola de Biblioteconomia dos anos 1937 e 1938”, consultado no arquivo histórico da Biblioteca Pública Municipal de São Paulo.

${ }^{110}$ Francisco Pati nasceu em Amparo, em 18 de fevereiro de 1898, e formou-se em Direito pela Faculdade do Largo São Francisco em 1923. Frequentou as redações dos jornais Correio Paulistano e Folha da Manhã (atual Folha de S. Paulo), além de publicar cinco obras (entre poesia, romances e ensaios sobre política). Sua participação no Correio Paulistano e sua defesa da necessidade de uma constituição em 1931 parecem indicar uma aproximação ao grupo do PRP. Atuou no Jornal Folha da Noite no período em que o periódico escrevia contra os modernistas aliados a Mário de Andrade. Em 27 de abril de 1923, Pati publica "O crime de Oscar Wilde: São Paulo e seus homens de letras", em resposta ao discurso de Mário de Andrade como paraninfo no Conservatório Dramático e Musical de São Paulo associando crime, homossexualidade, Oscar Wilde e Mário de Andrade (VERGARA, 2018). Foi, durante 35 anos, diretor do Departamento de Cultura.
} 
pública nestes casos, cada lado se muniu das alianças possíveis nas procuradorias e setores jurídicos de seus órgãos, produzindo interpretações em sua defesa. Nesse movimento, os membros do Departamento de Cultura se movimentaram em direções opostas, criando um impasse fatal para o destino da Escola. Francisco Pati consultou a Procuradoria do Município e recebeu do Diretor do Departamento Jurídico, Oswaldo Aranha Bandeira de Melo, a resposta de que a acumulação de cargos estava vedada pelo novo dispositivo legal. A argumentação era a de que o texto que criou o Departamento de Cultura estabelecera como uma das funções da Divisão de Bibliotecas: "organizar anualmente um curso de biblioteconomia"111 e que esse dispositivo havia sido acionado para justificar a criação da Escola; logo, não havia como justificar que o trabalho na Escola fosse extraordinário às obrigações do Diretor da Divisão de Bibliotecas e, portanto, não faria jus a um vencimento extra. Baseado nesse parecer e provavelmente preocupado com as responsabilidades administrativas que poderiam recair sobre si mesmo, Pati decidiu suspender os repasses de 2:000\$000 (dois contos de réis) ${ }^{112}$ para a Escola em junho de 1938.

Esse introito com minúcias jurídicas e administrativas, ainda que longo, permite apreciar a estratégia de Rubens Moraes e avaliar o impacto que a questão apresentou para a configuração do campo bibliotecário na São Paulo dos anos 1930. As dificuldades que o caso impunha iam muito além do interesse pessoal do próprio Rubens Moraes ou de Adelpha de Figueiredo, afetados diretamente naquele momento; como praticamente todos os bibliotecários no período eram funcionários públicos, solucionar a questão do acúmulo de vencimentos se tornou crucial para evitar que a Escola desaparecesse por falta de professores.

Por isso, Rubens Borba busca uma estratégia argumentativa sofisticada. O início consistiu em mostrar números de sucesso da escola: três turmas matriculadas, totalizando mais de 240 alunos e a entrega de diplomas a mais de 60 bibliotecários já na primeira formatura. Era mister, portanto, encontrar uma continuação para a escola. A primeira tentativa envolvia o Conselho Bibliotecário, pois, embora ele também fosse presidido pelo próprio Rubens Moraes, poderia ser apresentado como um intermediador legítimo, reforçando seu papel designado por lei estadual de regulador das atividades da classe bibliotecária.

\footnotetext{
${ }^{111}$ Ato do Executivo Municipal de São Paulo no 1146, de 6 de julho de 1936, art. 195, letra E. Cf. SÃO PAULO (Cidade). Ato do Executivo Municipal de São Paulo no 1146, de 4 de julho de 1936. Consolida e modifica disposições referentes aos serviços, repartições e funcionários da Prefeitura, e dá outras providências. Diário Oficial da Cidade, 07 jul. 1936, p. 1. Disponível em: http://legislacao.prefeitura.sp.gov.br/leis/ato-gabinete-doprefeito-1146-de-7-de-julho-de-1936. Acesso em: 20 de maio 2020.

${ }^{112}$ Algo em torno de R\$ 30 mil em valores de 2021.
} 
O diálogo se dera com um consultor jurídico da Secretaria Estadual de Educação e Saúde Pública, João Mendes Neto, e com o antecessor de Oswaldo Melo, chamado Paulo Barbosa de Campos Filho. Segundo Moraes, teria se construído (informalmente) uma compreensão de que o caso da Escola de Biblioteconomia poderia ser equiparado ao dos docentes das escolas profissionais paulistas, para os quais a gratificação já teria sido aprovada pelo interventor federal, Adhemar de Barros. ${ }^{113} \mathrm{O}$ argumento de Moraes tinha um ponto forte: a profissão de bibliotecário e a própria escola já haviam sido reconhecidas pela Lei Estadual 2839, de 05 de janeiro de 1937. O caso das outras escolas profissionais também criava uma jurisdição favorável. E, para terminar, havia a possibilidade de sensibilizar Francisco Pati e os procuradores do Município pela publicidade que a Escola alcançara e pela decisão de Moraes de não interromper as atividades, mesmo após ter sustados os pagamentos aos funcionários.

Por outro lado, o argumento de Moraes também possuía pontos fracos. As escolas profissionais mencionadas como jurisprudência não tinham o mesmo caráter de formação em nível superior que a Biblioteconomia tinha e que era resultado de uma das bandeiras de mobilização do próprio Rubens, desde 1936. Ora, se a formação era diferente das outras escolas, então não poderia se justificar a gratificação por esse caminho. Mas se a formação fosse apresentada como sendo do mesmo nível das outras escolas, ganhava força o argumento de que cuidar do aperfeiçoamento da atuação dos funcionários da Divisão de Bibliotecas já faria parte das atribuições do seu Diretor e tampouco seria justificável continuar a pagar um valor a mais.

Diante do impasse, a Procuradoria do Município de São Paulo exarou uma série de pareceres $^{114}$ cujas entrelinhas transpiraram o esforço de agradar a todos os envolvidos. Manteve-se o entendimento de que o pagamento de gratificações nos moldes anteriores não

\footnotetext{
${ }^{113} \mathrm{O}$ Governo do Estado produziu um Ato Administrativo em 10 de janeiro de 1938; menos de 60 dias depois do decreto-lei federal, estabelecendo que 'gratificações só serão pagas a funcionários que exerçam funções especiais, extraordinárias ao cargo'. O mesmo princípio foi confirmado no Decreto 9.303 de 6 de julho de 1938, inicialmente versado sobre as escolas profissionais sob abrigo do Governo Estadual, mas que seria invocado como argumento em seus dois primeiros artigos:

"Artigo 1.- - São consideradas funções extraordinárias legais e regulamentares as especificadas no presente decreto e atribuídas, no ensino profissional, a funcionários públicos e a empregados das empresas industriais do Estado. Artigo $2 .^{\circ}$ - Só poderão ser designados para os serviços referidos neste decreto os funcionários que exerçam cargos cujas funções correspondam ou sejam correlativas as que vão exercer, e sem prejuízo daquelas." (SÃO PAULO (Estado) Decreto n. 9.303, de 6 de julho de 1938. Consolida disposições sobre pagamento de gratificações para serviços extraordinários no ensino profissional e dá outras providências. Diário Oficial do Estado de São Paulo: Secretaria de Estado da Educação e Saúde Publica, 6 jul. 1938. Disponível em: https://www.al.sp.gov.br/repositorio/legislacao/decreto/1938/decreto-9303-06.07.1938.html. Acesso em: 07 abr. 2021).

1141) Parecer de Carlos Monteiro Brisolla, de 12 de novembro de 1938. 2) Despacho de H. Meirelles Teixeira, de 14 de novembro de 1938. 3) Ofício de Oswaldo Aranha Bandeira de Mello ao Departamento de Cultura, de 10 de dezembro de 1938. Todos eles foram apensados ao processo $\mathrm{n}^{\circ}$ 68.268/1938.
} 
deveria mais ser permitido; assim, confirmou o arrazoado dos procuradores e as decisões do Diretor do Departamento de Cultura. Mas ainda faltava satisfazer a Rubens Borba de Moraes.

Para realizá-lo, a procuradoria sugeriu que se revogasse apenas a letra “e' do art. 195 do ato do Executivo Municipal de São Paulo no 1.146, de 4 de julho de 1936. Desatava-se, assim, o nó que travava a questão. Em substituição a isso, o prefeito poderia fazer publicar novo ato administrativo em que a Escola de Biblioteconomia fosse regulada como uma entidade à parte, independente da Divisão de Bibliotecas, ou até mesmo eleger uma entidade de direito privado, ainda que subvencionada pela prefeitura, para essa finalidade. Em ambos os casos, ficaria caracterizada a diferença de funções que justificaria a volta ao pagamento das gratificações. Ainda assim, os procuradores se reservavam o direito de voltar a analisar o tema dos acúmulos de cargos após a criação da Escola.

No resumo da ópera, vê-se que o caso não era de aplicação fria de uma lei rígida, mas de disputa de forças na composição da interpretação dos diplomas legais cabíveis. Nessa situação, a procuradoria tentou assumir para si o papel de árbitro, entendido não como lado isento do jogo, mas como alguém em busca de saídas para premiar a todos os envolvidos na tertúlia. A saída salomônica parecia ter agradado haja vista o rápido encaminhamento: em 03 de janeiro de 1938, Moraes encaminha ao Prefeito a última juntada de documentos para que ele pudesse tomar sua decisão. Esta chega em 16 de janeiro de 1938, em um curto despacho escrito de próprio punho no qual consta a manutenção da Escola, nos termos propostos pela Procuradoria. Finaliza encaminhando para o Departamento de Cultura tomar as providências cabíveis. Este, por sua vez, encaminha o caso já no dia seguinte (17 de janeiro) para o Diretor da Divisão de Bibliotecas sugerir a redação do novo ato.

A resposta de RBM, oficiada em 26 de janeiro de 1939, constitui uma das peças mais enigmáticas do processo. Em vista de sua derrota no convencimento dos procuradores, era razoável supor que aceitaria o tema da separação entre Escola de Biblioteconomia e Divisão de Bibliotecas como assunto encerrado; em troca, poderia negociar sua confirmação como diretor da Escola, já em seus novos moldes - para isso poderia contar com o sucesso de sua empreitada anterior, talvez com o mesmo apoio informal que os procuradores já haviam demonstrado e possivelmente com a inércia das decisões burocráticas: se ele já era diretor, por que retirá-lo? Todas essas suposições caem por terra quando se lê qual foi sua proposta para o novo artigo:

Art. Fica criada a Escola de Biblioteconomia do Departamento Municipal de Cultura, cujos fins são os de dar instrução técnica às pessoas que se destinam à carreira de bibliotecário. 
Art. A Escola de Biblioteconomia do Departamento de Cultura ficará subordinada à Divisão de Bibliotecas e será dirigida pelo chefe da referida Divisão, de acordo com o regulamento a ser expedido dentro de sessenta (60) dias, a contar da publicação deste Ato.

Art. O Chefe da Divisão de Bibliotecas poderá designar funcionários dessa Divisão para, sem prejuízo de suas funções ordinárias, prestarem serviços na Escola de Biblioteconomia, serviços esses que terão o caráter de funções suplementares.

Art. As despesas com a manutenção da Escola de Biblioteconomia ocorrerão pela verba n. 7240 do orçamento vigente.

Art. Pelos serviços suplementares que prestarem na Escola de Biblioteconomia perceberão, tanto o chefe da Divisão, como os funcionários por ele designados, gratificações mensais. Art. Fica revogada a letra do art. 195 do Ato n. 1146, de 4 de julho de 1936. (SÃO PAULO, 1938, p. 1)

Note-se que, pela proposta de Moraes, a Escola de Biblioteconomia continua a fazer parte do organograma da Divisão, que os vencimentos extras ficam não apenas mantidos, mas até flexibilizados, pois o texto sequer obriga o Diretor a ser um dos lentes do curso para perceber o emolumento. Por que Moraes formula uma redação de Ato em pleno desacordo com o encaminhamento prévio? E o que isso nos permite afirmar sobre o estatuto de sua posição e dos demais bibliotecários envolvidos?

Posto que dificilmente Moraes recomendaria uma lei contra seu interesse pessoal, a citação logo acima permite concluir que ele não temia ser exonerado da Direção da Divisão, mas não tinha o mesmo grau de certeza quanto à Direção da Escola. Neste ponto, abrem-se uma série de conjecturas que nos permitimos fazer e assim formular uma série de alternativas: 1) Moraes temia que a Escola fosse entregue a outros(as) bibliotecários(as) com quem ele não tivesse convergência e, dessa forma, seu projeto de formação de uma nova biblioteconomia estaria em risco; 2) Moraes temia que a separação da Divisão de Bibliotecas, com orçamento próprio, pusesse em risco a própria existência da Escola; 3) Moraes julgou que não teria apoio suficiente para fazer aprovar o pagamento da gratificação, mesmo que a escola fosse organizada de modo independente. Essa hipótese seria a menos provável.

Em qualquer uma dessas três alternativas, ficaria evidente uma derrota nos planos de afirmação da formação em Biblioteconomia como uma atividade autônoma. Na melhor das hipóteses, o único instituto de formação de bibliotecários ficaria sob a direção de um nome a ser escolhido ao sabor das conveniências políticas, dentro de um cenário tão instável quanto as ondas do mar. Afinal, o relacionamento de Moraes com a nova gestão da Prefeitura e do Estado $^{115}$ instaurados pelo Estado Novo já havia acumulado desgastes. Ainda que fossem

\footnotetext{
${ }^{115} \mathrm{O}$ novo estatuto do regime varguista havia representado, no cenário paulista/paulistano, a emergência com força do interventor federal no Estado, Adhemar de Barros, que por sua vez nomeou Prestes Maia como interventor na
} 
bibliotecários, seria impossível imaginar a Escola como formadora do campo epistêmico, com produção de massa crítica de estudos e especializações no corpo docente que só renderiam frutos em um investimento contínuo por décadas.

Na pior das hipóteses, a destruição por completo da Escola seria uma questão de tempo. Por mais que busquemos objetivações das alianças e poderes pessoais estabelecidos tacitamente, ainda que presentes no cotidiano da administração pública, registrada em sisudos processos, muito se perde neste tipo de fonte, e chega-se a um limite do que é possível afirmar sobre o passado.

Seja porque Rubens Moraes já contava com isso ao enviar o fatídico ofício em 26 de janeiro de 1939, seja por reação a ele, o fato é que o ritmo do processo desacelerou, ao mesmo tempo em que sofreu uma guinada de 180 graus. Depois de ficar um mês com o processo para responder a Moraes, Francisco Pati decide encaminhar ao Prefeito, em 27 de fevereiro de 1939, a sugestão de que a Escola de Biblioteconomia permaneça dentro da Divisão de Bibliotecas, portanto sem direito a gratificação alguma. Prestes Maia pontua que não deveria ser função do Município produzir profissionais competentes para outras instituições para além da própria Prefeitura e ordena que até o orçamento da escola seja suprimido. Por fim, requisita a opinião do professor Fidelino de Figueiredo.

O despacho do prefeito é muito significativo e merece atenção detida. Até aquele momento, não havia no processo nenhuma crítica ao escopo da ação da Escola - pelo contrário, até os procurados haviam se manifestado por sua importância no cenário cultural brasileiro. A fala de Prestes Maia encontra-se em flagrante oposição ao projeto político do grupo de Armando Salles de Oliveira e de seus apoiadores entre os modernistas.

Visto que Oliveira já havia anunciado sua pretensão de substituir Vargas nas eleições que acabaram canceladas pelo Estado Novo, nota-se uma sintonia entre a mudança do tabuleiro nas três esferas políticas (nacional, estadual e federal) e a queda de braço em torno do projeto de Biblioteconomia representado pela Escola. Fazendo frente ao projeto cultural de Moraes, Prestes Maia solicita parecer a Fidelino de Figueiredo, português recém-chegado ao Brasil, exilado do salazarismo. Figueiredo exprime-se em 29 de julho de 1939, mostrando-se inicialmente favorável à criação de um curso superior em Biblioteconomia, mas pela Universidade de São Paulo, onde lecionava. Também sugere que se poderia criar um Curso de

Prefeitura da Capital. Como é de praxe nestes casos, a dança das cadeiras no comando destas duas esferas do Executivo - intimamente ligadas entre si - alterou por completo o cotidiano de trabalho e pode, inclusive, ajudar a explicar o surgimento do problema do financiamento para a Escola de Biblioteconomia. Dito de outra forma, não é apenas a existência da letra fria da lei, mas os agentes públicos que zelam por sua interpretação e execução que ajudam a explicar porque o projeto da Escola de Biblioteconomia perdeu espaço em um período tão curto. 
Biblioteconomia e Arquivologia, no Departamento de Cultura, "sem pretensões enciclopédicas, só com a matéria indispensável e possível em tão curto prazo de tempo" (SÃO PAULO, 1938a, s. p.), com noções de Bibliologia, Arquivologia, Paleografia, Biblioteconomia, Bibliotecografia, Cartografia, Numismática, Medalhística, além de uma formação geral sobre Brasil e Portugal. Em vista da quantidade de temas tratados e do tempo de formação previsto (2 anos), os temas seriam tratados de forma introdutória, nas palavras do próprio Fidelino de Figueiredo. Seu parecer é a última manifestação do processo, seguida do seu encaminhamento para arquivamento, em outubro do mesmo ano.

A análise do processo $n^{\circ} 68.268 / 1938$ permite enxergar como, apesar da rápida expansão das instituições a tratar da atividade bibliotecária, nos anos 1930, ocorreu um limite intrínseco à configuração do campo, assim como ocorrerá com diversas outras atividades socioculturais. Refém de uma cultura nacional caracterizada por um déficit institucional que mina a estabilidade nas decisões da administração pública, a implementação de políticas de longa duração altera o destino das repartições tanto aos egos como às disputas políticas de seus diretores; a Escola representou o surgimento e o temporário ocaso de um projeto de biblioteconomia que poderia contribuir, através da formação de leitores, para alterar esses status quo cultural letrado, no país.

Deve-se reforçar, no entanto, que o recuo político, sustentado via aparelho burocrático, foi temporário, pois algumas das iniciativas dos anos 1930 vão perdurar ou mesmo evoluir nas décadas seguintes, algumas com participação do próprio Rubens. As trajetórias incertas dessas iniciativas permitiram configurar o que hoje compreendemos como campo bibliotecário e não foram exclusividade da cidade de São Paulo, ocorrendo também, por exemplo, no Rio de Janeiro, conforme atesta a supressão violenta do Pavilhão Mourisco, projeto pioneiro de criação de uma biblioteca infantil no país, conduzido por Cecília Meireles e que instalou, no bairro do Botafogo, um verdadeiro centro cultural, destinado a crianças e jovens (PIMENTA, 2011).

Na procura das digitais de RBM deixadas ao longo de sua trajetória, vamos tratar, assim, dessa retomada da "luta", no próximo capítulo. Antes, porém, cabe observar que a Escola de Biblioteconomia, tendo à frente seus idealizadores, foi levada para dentro da Escola Livre de Sociologia e Política de São Paulo, atendendo a uma sugestão dos procuradores municipais; neste sentido, consistiu em um aprendizado adquirido na experiência do processo em tela neste item. Nem tudo se perdeu, mesmo nas derrotas. 


\section{UM BIBLIOTECÁRIO MODERNISTA - A BUSCA DE RECONHECIMENTO E AFIRMAÇÃO DA BIBLIOTECONOMIA BRASILEIRA}

O presente capítulo pretende apresentar a legislação que originou o primeiro Conselho Bibliotecário e também as ações da primeira associação profissional de Bibliotecários do Brasil. Pretende-se com este capítulo demonstrar os desdobramentos da Escola de Biblioteconomia do Departamento de Cultura, cujo fechamento, em 1939, não impediu que outros frutos continuassem surgindo, como, por exemplo, a mencionada criação de uma segunda Escola de Biblioteconomia, agora anexa à Escola Livre de Sociologia e Política de São Paulo. Além disso, acompanharemos os discursos de RBM a respeito da situação das bibliotecas no país, buscando indicar como seu projeto, além da criação de Bibliotecas, e da formação de quadros para aí atuarem, implicava também a profissionalização e o reconhecimento oficial de um campo profissional e de saberes novos no Brasil, relacionado direta e essencialmente à constituição e afirmação da cultura letrada, no país.

\subsection{A Biblioteconomia no Legislativo e o Conselho Bibliotecário}

Enquanto dirigia a Divisão de Bibliotecas e a Escola de Biblioteconomia no Departamento de Cultura, Moraes empenhou-se em institucionalizar também organismos profissionais, como o Conselho Bibliotecário (1937) ${ }^{116}$ e a Associação Paulista de Bibliotecários (1938). A criação das duas instituições representa a posição de Moraes de que o projeto de afirmação do papel social da biblioteca e dos bibliotecários só se sustentaria se viesse acompanhado de organismos profissionais que lhe dessem sustentação profissional e intelectual. Moraes começa a bater-se pela articulação política em torno desse projeto desde a

\footnotetext{
${ }^{116}$ No mesmo ano de criação do Conselho Bibliotecário em São Paulo, o Ministério da Educação e da Saúde decide implementar o Instituto Nacional do Livro. O Instituto federal viria a propor ações de organização e desenvolvimento de um sistema bibliotecário nacional. Ainda assim, a representatividade do Conselho Bibliotecário extrapolaria o panorama bibliotecário do Estado de São Paulo, a começar pela formação de bibliotecários seguida das mobilizações orquestradas pelo Conselho e na participação de seus membros em ações políticas e artísticas ligadas à democratização cultural. Em 1945, Rubens Borba de Moraes representa o Conselho de Bibliotecários no I Congresso Brasileiro de Escritores, realizado em São Paulo. No evento, discutiu-se as condições de volta do país à legalidade democrática, com uma Constituição que estabelecesse a liberdade de expressão e processos eleitorais diretos com voto secreto para a escolha dos membros do Executivo e do Legislativo, conforme o rito democrático. Cf.: ABREU, A. A. de. Congresso Brasileiro de Escritores, I. In: Dicionário Histórico-Biográfico Brasileiro - Verbete. CPDOC/FGV Centro de Pesquisa e Documentação de História Contemporânea do Brasil, 2009. Disponível em: http://www.fgv.br/cpdoc/acervo/dicionarios/verbetetematico/congresso-brasileiro-de-escritores-i. Acesso em: 09 dez. 2020.
} 
segunda metade da década de 1930, e a oficialização do Conselho e da Associação marcam a vitória em um processo iniciado anos antes.

O Conselho Bibliotecário é resultado de um projeto de lei apresentado à Assembleia Legislativa de São Paulo em outubro de 1936, por Paulo Duarte e Ernesto Leme (NEGRÃO, 1979), e regulamentado através da Lei 2.839 de 05/01/1937. Uma análise mais detida da lei demonstra como ela traz ganhos para o projeto defendido por Rubens Borba de Moraes.

O primeiro artigo definia as atribuições do Estado e dos Municípios em relação "ao desenvolvimento de bibliotecas no Estado" da seguinte maneira:

Parágrafo $1^{\circ}$ - Competem ao Estado os referidos serviços em relação às bibliotecas universitárias, às dos institutos especializados e às anexas a repartições e escolas públicas estaduais.

Parágrafo $2^{\circ}$ - Competem ao Município os mesmos serviços em relação às bibliotecas não especializadas, às das repartições municipais e às populares e infantis, quando não forem anexas a estabelecimentos estaduais de ensino. (SÃO PAULO, 1937b, p. 3)

Ao estabelecer responsabilidade para cada uma das esferas, a lei Estadual determinava a importância e magnitude do trabalho de "acompanhamento, manutenção, administração e desenvolvimento das bibliotecas" para o "aparelhamento bibliotecário" de todo o Estado de São Paulo. Para Moraes, o primeiro objetivo da lei foi o de definir "a atribuição do Estado e do Município em matéria bibliotecária de maneira a estabelecer uma cooperação das mais úteis e evitar duplicidade e desperdício de esforços" (MORAES, 1936, p. 1).

Note-se que o artigo propunha que as bibliotecas especializadas ficassem majoritariamente ao encargo do poder estadual, enquanto as populares e infantis caberiam ao poder municipal. Tal arranjo confirmava a divisão de tarefas que já havia sido proposta por Mário de Andrade, quando de sua passagem pelo Departamento de Cultura do Município, algo que pode explicar a concordância de Rubens com a lei. Em complemento, havia a preocupação com as cidades menores que porventura não tivessem recursos para abrir outras bibliotecas, para as quais o artigo 19 ofertava a possibilidade de funcionamento da biblioteca pública junto à biblioteca escolar estadual.

A lei que institui o Conselho Bibliotecário representou grau a mais na constituição do campo, pois abria caminho para aspecto essencial a seu desenvolvimento: a profissionalização, sua regulamentação e reconhecimento social. Era a primeira vez que se propunha uma organização para o mercado de trabalho dos bibliotecários, o que, segundo Moraes (1936,p. 1), "veio a preencher notável lacuna na legislação estadual e federal". Segundo ele, o Brasil era um 
dos poucos países que não possuía legislação em matéria de Biblioteconomia (MORAES, 1982).

O Conselho Bibliotecário tinha como missão auxiliar na fiscalização do cumprimento da lei, constituído por cinco membros assim representados:

-Um chefe do serviço de qualquer das bibliotecas universitárias;

-Um representante da Diretoria do Ensino;

-Um bibliotecário de qualquer dos institutos especializados;

-O Chefe da Divisão de Bibliotecas do Município da Capital;

-Um representante do Departamento de Cultura do mesmo Município. (SÃO

PAULO, 1937b, p. 3).

O grupo empenhado em consolidar o Conselho, além de buscar representantes de diferentes tipos de bibliotecas, incluiu, também, as duas instituições com maior autoridade no Estado, no que diz respeito às relações Bibliotecas e Educação: a Divisão de Bibliotecas e a Diretoria do Ensino. Moraes faria parte do corpo do conselho como diretor e chefe da Divisão de Bibliotecas e Jorge de Andrade Maia, ${ }^{117}$ médico bibliotecário na Faculdade de Medicina da USP, ficaria como interino nos períodos de ausência do presidente, $\mathrm{RBM}^{118}$.

Assim como o Departamento de Cultura, representantes da área da Educação e da Universidade de São Paulo vinham dedicando esforços para conectar e ampliar as bibliotecas abertas aos públicos, fossem elas escolares, para pesquisadores, ou de uso geral ${ }^{119}$. Por este motivo, foi proposta na mesma lei um "Catálogo Geral das Bibliotecas Paulistas", reunindo acervos de bibliotecas de todo o Estado de São Paulo:

Artigo 8. ${ }^{\circ}$ - Fica criado o Serviço de Catálogo Geral das Bibliotecas Paulistas, subordinado ao Conselho Bibliotecário, de acordo com o art. 7. ${ }^{\circ}$ letra "d".

Artigo 9. ${ }^{\circ}$ - O catálogo geral terá por fim estabelecer a centralização dos repertórios de todas as bibliotecas paulistas num catalogo único, tecnicamente organizado.

\footnotetext{
${ }^{117}$ Além de ser o principal bibliotecário da Faculdade de Medicina da USP, Jorge de Andrade Maia atuou em projetos do Departamento de Cultura relacionados à produção de dicionários e bibliografias especializadas em Medicina. Segundo Valentini (2010), o bibliotecário participou também da equipe técnica de construção de um vocabulário etnográfico junto com Mário de Andrade, Paulo Duarte, Oneida Alvarenga Dina Deyfrus e Levi Strauss; projeto que não se concretizou.

${ }^{118}$ Cf. SÃO PAULO. Secretaria da Educação. Actos Officiaes. In: Correio Paulistano. São Paulo, ano 1937a, ed. 24951, p. 10, 16 jul. 1937. Disponível em: http://memoria.bn.br/DocReader/090972_08/19386. Acesso em: 10 abr. 2021.

${ }^{119}$ Além dos projetos da Divisão de Bibliotecas sobre os quais já discorremos nesta tese nos capítulos anteriores, temos também, nos anos 1930, o Manifesto dos Pioneiros da Educação Nova, de 1932, com figuras de projeção como Fernando de Azevedo, Anísio Teixeira, Lourenço Filho, dentre inúmeros outros, que se empenharam na restruturação do ensino e da escola pública brasileira. O movimento que ficou conhecido como o da "Escola Nova" interpelava pela criação de bibliotecas escolares como extensão da educação (AZEVEDO et al, 2010).
} 
Artigo $10 .^{\circ}$ - Todas as bibliotecas do Estado - municipais ou estaduais são obrigadas a atender às requisições e instruções do Serviço de Catálogo Geral. Parágrafo único - Poderão fazer parte do catálogo geral quaisquer bibliotecas não oficiais que o desejem, desde que se submetam ao Regulamento do Serviço e ao Conselho Bibliotecário.

(SÃO PAULO, 1937a, p. 3).

A criação de bibliotecas conectadas entre si representa uma mudança na concepção de biblioteca, que deixa de ser isolada e passa a ser vista de uma forma sistêmica, ganhando densidade e volume, podendo otimizar serviços nas trocas que tal sistema facilita, ao se organizar sob premissas da colaboração. A cooperação inter-unidades permite que cada uma delas deixe de ser vista, também, como responsável por abrigar todo o conhecimento que o usuário deve aceder, para pensar neste conhecimento como composto por partes intercomunicáveis entre si, embora nunca completamente preenchidas. É, portanto, uma ruptura epistêmica que está sendo introduzida na legislação da época. A lei traz implícito o reconhecimento de que nenhum acervo no país, apesar dos grandes problemas de nosso mercado de livros, poderia se dizer definitivo sobre um ou todos os ramos do conhecimento. Por outro lado, a possibilidade de uso pelos leitores de materiais de diferentes unidades do sistema traria novas possibilidades de acesso à pluralidade de materiais bibliográficos espalhados pelo sistema e que não se repetiam exatamente da mesma forma em cada unidade.

Um sistema ordenado entre as bibliotecas, cuja interface com o leitor fosse cuidadosamente planejada, trazia exigências de um(a) profissional de bibliotecas à altura do desafio. Ao menos parecia ser isso o que pensavam os legisladores, posto que se preocuparam em definir termos para a admissão de novos bibliotecários aos seus respectivos cargos, impondo condições restritas de acesso. O acesso aos cargos estaduais ou municipais de bibliotecário seriam preenchidos por concurso de provas, por candidatos com "diploma de curso superior e de biblioteconomia”. A Escola da Divisão forneceria formação ao bibliotecário e o conselho fiscalizaria o atendimento à lei. Antes mesmo que a lei surtisse os primeiros efeitos previstos, a divulgação da regulamentação profissional do bibliotecário desencadearia, ao longo do ano seguinte, a preocupação em representantes de bases de governos de diferentes municípios em organizar seus sistemas bibliotecários, além de servir de inspiração para lideranças de outros países da América Latina ${ }^{120}$.

\footnotetext{
${ }^{120}$ No fundo que preserva a documentação pessoal de RBM, há correspondências trocadas entre ele e Magda Arce (Chile), entre 1937 e 1942, além de um pedido de informações sobre a realidade paulista, emitido pela Biblioteca Nacional da Argentina para RBM, em correspondência datada de 7 de setembro de 1939. Além disso, representantes políticos, além de diretores de bibliotecas e arquivos de diferentes unidades federativas do Brasil solicitaram cópia da lei e também orientações para que os Estados pudessem seguir o exemplo de São Paulo.
} 
Também foi a Lei 2.839 que oficializou a realização de um antigo anseio de Moraes: a fusão de acervos da Biblioteca do Estado e da Biblioteca Pública Municipal de São Paulo, atual Biblioteca Mário de Andrade. O intento foi possível, pois estava prevista a transferência de gestão da Biblioteca Pública do Estado para o município, em consonância com a divisão proposta no artigo $1^{\circ}$ da lei.

Neste aspecto, a primeira das funções do Conselho Bibliotecário, estabelecida pelo artigo $7^{\circ}$, consistia justamente na articulação de trabalhos entre as duas esferas administrativas públicas, como deixa entrever a redação final:

Artigo 7. ${ }^{\circ}$ - Compete ao Conselho: a) coordenar trabalhos entre as bibliotecas estaduais e municipais; b) tomar e fazer executar medidas necessárias à corporação entre as bibliotecas; c) - resolver, segundo os casos, com qualquer Secretaria de Estado ou Repartição pública, Conselho Universitário, Diretoria do Ensino, prefeituras municipais, ou qualquer dos Institutos especializados sobre a redistribuição dos acervos das diferentes bibliotecas, tendentes o melhor aproveitamento das coleções; d) - superintender o serviço de catalogo geral das bibliotecas paulistas e tomar as medidas necessárias para a sua boa execução; e) - solicitar às autoridades competentes as medidas necessárias, em qualquer das bibliotecas, para regularizar a sua vida interna ou trabalhos técnicos, quando em desacordo com o plano geral estabelecido; f) - estabelecer as bases para a unificação e padronização dos trabalhos técnicos nas bibliotecas do Estado; g) - promover a vulgarização dos trabalhos relativos à biblioteconomia; h) - prestar auxilio técnico, centralizar as estatísticas, promover intercâmbio com as bibliotecas nacionais e estrangeiras; i) promover os concursos de entrada na carreira de bibliotecário, remetendo a lista dos aprovados ao Governo, para a nomeação; j) - organizar o cadastro das bibliotecas paulistas. (SÃO PAULO, 1937b, p. 3).

Podemos organizar as contribuições da Lei 2839, do seguinte modo: a) definição e reconhecimento de um campo de atuação profissional, por meio da regulamentação da profissão e promoção de um espaço de discussão sobre o lugar das bibliotecas na sociedade; b) qualificação dos serviços bibliotecários favorecidos pela regulamentação profissional; c) definição de um conceito de gestão sistêmica, resultante na proposta de construção de um catálogo coletivo, envolvendo bibliotecas de diferentes portes e natureza. Pode-se avaliar, portanto, que a lei promulgada em 1937 tinha grande peso na orquestração do plano bibliotecário e significava uma inovação significativa em termos de propostas na área de políticas e de gestão pública, não só no estado, mas no país.

(Correspondência enviada por José Joaquim G. de Piva Filho a Rubens Borba de Moraes no dia 12 de janeiro de 1939, disponível no Arquivo Histórico da Biblioteca Mário de Andrade). 
A participação de Rubens Borba de Moraes na elaboração da lei parece estar indicada por um rascunho preservado entre seus documentos pessoais ${ }^{121}$. No rascunho, é possível notar a preocupação de que o texto contido ali fosse levado sem modificações ao plenário, depois de já ter sido aprovado nas duas comissões pertinentes: a de Constituição e Justiça e a de Educação e Cultura ${ }^{122}$.

Há dois argumentos principais no texto de Rubens Borba de Moraes. O primeiro deles procura convencer os deputados dos exemplos internacionais que serviriam de inspiração para a lei proposta. Aqui entra em ação o pressuposto de que São Paulo deveria se "adiantar" em relação ao resto do país na produção de bons exemplos de serviços ao público, inspirando-se em experiências internacionais que poderiam servir de modelo.

Nesse sentido, Moraes inicia lembrando que a Liga das Nações ${ }^{123}$ fizera um pouco antes um listado da legislação mundial no campo e o Brasil estaria em situação vergonhosa, representada apenas por um regulamento da Biblioteca Nacional. Moraes faz questão de frisar, "do Rio de Janeiro", certamente provocação em torno da disputa entre as esferas federal e estadual.

Vale observar que a invocação, tão acriticamente reproduzida pela literatura da Biblioteconomia, sobre a rixa estruturante entre a Biblioteconomia de São Paulo e do Rio de Janeiro, não aparece no argumento de Moraes. Não há na sua colocação oposição entre uma suposta Biblioteconomia "humanista" versus outra "técnica" / "pragmática". O lugar comum e dual parece ter sido consagrado mais pela literatura posterior, que não se debruça sobre os documentos e acaba se fundando no senso comum e alimentando disputas provincianas, que pelas preocupações reais em causa e que diziam respeito à adoção de projetos não só locais, mas nacionais, afinados com um modelo de modernização urbano-industrial de abrangência

\footnotetext{
${ }^{121} \mathrm{O}$ documento manuscrito está disponível na pasta referente a Rubens Borba de Moraes, no fundo do Departamento de Cultura do Instituto de Estudos Brasileiros, com data atribuída em 1936 pelo catálogo da Instituição.

${ }^{122}$ Cabe uma breve explicação sobre os trâmites para aprovação de uma lei naquele período, que não se distinguem em muito dos atuais. Quando um projeto de lei (PL) é oficialmente apresentado, precisa ser aprovado em Comissões temáticas antes de ir a plenário. Sua primeira análise é para saber se o conteúdo do PL atendia a todos os requisitos legais em sua formulação e se não incorreria em tema que não pertenceria à competência estadual. Essa análise era, portanto, dedicada à forma do projeto e era realizada pela Comissão de Constituição e Justiça. A segunda análise era sobre o mérito do projeto e, como nesse caso incidia temas ligados à Educação e Cultura, ficou a cargo da comissão existente para tal. É significativo que não houvesse registro de que ela tivesse passado pela Comissão de Orçamento, passo obrigatório quando o PL obriga o Estado a dispender alguma verba para cumprimento da lei.

${ }^{123}$ A Liga das Nações foi criada logo após o final da Guerra Mundial de 1914, para supostamente evitar que um conflito daquelas proporções voltasse a ocorrer um dia. Apesar de seu rotundo fracasso, serviu como primeira experiência de criação de uma esfera diplomática internacional, que pudesse coordenar esforços de temas de interesse comum em escala planetária - e o caso da biblioteconomia e da documentação constituiu um exemplo por excelência.
} 
nacional. Moraes chama ao esforço de produção de um catálogo único das bibliotecas paulistas como “obra de maior alcance intelectual” e não somente técno-funcional. Defenderá tal modelo, não apenas para São Paulo, mas para o país, uma vez que o problema do atraso do país, em seu entendimento, não é localizado, mas nacional. A atuação, a partir de São Paulo, é estratégica e não estrutural.

Do ponto de vista do feito intelectual, Moraes chama a atenção para os benefícios que especialistas e pesquisadores de todo o Estado poderiam ter ao conseguirem obter acesso a toda a documentação disponível para pesquisa, no sistema estadual, ampliando o escopo de suas pesquisas. A formação do catálogo deveria tomar como ponto de partida o interesse e as necessidades dos usuários, compondo uma descrição dos acervos em consonância com a erudição da pesquisa de ponta desenvolvida no estado.

Em termos de economia dos gastos públicos, o argumento era de que a formação de um catálogo único permitiria evitar a compra de duplicatas, racionalizar os serviços das bibliotecas do estado, propondo uma divisão de tarefas que as tornasse mais atraentes ao público e otimizasse o seu uso. Para isso, o rascunho de Moraes previa a criação de um organismo consultivo que prestasse auxílio às bibliotecas.

A arquitetura dos projetos voltados para as bibliotecas permite-nos observar a importância atribuída à concepção de "biblioteca colaborativa" que, contextualizada em sua realidade, abre seu acervo, por meio de sua inclusão no catálogo coletivo, para que usuários de outros dispositivos culturais pudessem usufruir de acervos de diferentes instituições. É nesse sentido que afirmamos que importava mais criar um sistema do que bibliotecas isoladas. $\mathrm{Ou}$ seja, a institucionalização do Conselho Bibliotecário ultrapassava interesses locais e municipais, enquadrando-se nas aspirações modernistas de construção de um projeto cultural que, valendo-se das condições especiais e favoráveis de São Paulo, no momento, se irradia, separa todo país.

O rascunho referido acima constitui peça relevante no sentido de tornar objetivas as condições pensadas por Rubens Borba de Moraes para a execução de um projeto brasileiro de Biblioteconomia. Consiste em mais uma evidência dentro da numerosa lista que aponta para a ausência da dicotomia nas propostas de Moraes entre a tecnicalidade dos métodos na abordagem da peça a ser indexada pelo bibliotecário e a formação cultural, a erudição que dele é exigida. 
Outro ponto de interesse do rascunho é a preocupação de RBM em chamar a atenção das autoridades públicas para a necessidade de regulamentação da profissão ${ }^{124}$ e participação no novo sistema bibliotecário, elemento essencial para o projeto de democratização cultural dos modernistas paulistas.

A despeito de que a lei estadual paulista promulgada em 05 de janeiro de 1937 tenha trazido contribuições para o desenvolvimento do campo da Biblioteconomia não só em São Paulo, mas também no Brasil, verificam-se também alterações significativas na confrontação do texto aprovado com o esboço de lei apresentado por Moraes. Cumpre observar as mudanças entre o rascunho escrito por este em relação ao texto final para compreender as mudanças nas estratégias de sua luta, que consistirá, dali em diante, em recuperar as perdas provocadas pela retirada de trechos de seu rascunho de anteprojeto de lei em relação ao texto legal definitivo.

A maior delas refere-se a ações que no documento precedente à lei foram descritas como competências da Diretoria de Bibliotecas. O documento de Moraes informava que à equipe, subordinada ao Conselho Bibliotecário do Estado, competia:

a) Organizar, incentivar e coordenar todos os trabalhos referentes a bibliotecas no Estado;

b) Estabelecer as bases para unificação e padronização dos trabalhos técnicos nas bibliotecas do Estado;

c) Solicitar às autoridades competentes as medidas necessárias para regularizar a vida interna ou trabalhos técnicos das bibliotecas quando em desacordo com a orientação geral por ela estabelecida;

d) Prestar auxílio técnico às bibliotecas que o solicitarem;

e) Adquirir livros e distribuí-los entre as bibliotecas;

f) Organizar catálogos coletivos e cadastro das bibliotecas do Estado;

g) Promover a vulgarização das obras relativas a biblioteconomia;

h) Promover intercâmbio com instituições congêneres nacionais e estrangeiras;

i) Dar instruções técnicas e culturais às instituições públicas e particulares, que desejarem fundar bibliotecas;

j) Promover o aperfeiçoamento técnico dos bibliotecários e facilitar a vinda para a capital de bibliotecários do interior, afim de seguirem cursos de biblioteconomia e fazer estágio em bibliotecas;

k) Promover reuniões e congressos bibliotecários; (MORAES, [1937b], p.1, grifo nosso).

\footnotetext{
${ }^{124}$ A proposição da Lei 2.839 de 1937 traria a cultura para dentro das preocupações em tirar a construção do país das mãos de leigos e inabilitados e passá-la para especialistas. Preocupações da mesma ordem já haviam surtido efeito na criação da Associação dos Advogados do Brasil (OAB), em 1930, e na instituição do Conselho das engenharias Confea/CREA, em 1933. Uma diferença significativa era que a proposição de lei foi apresentada ao governo estadual no bojo das inovações iniciadas pelo Departamento de Cultura em 1935, mas a OAB foi instituída por Getúlio Vargas através do Decreto $\mathrm{n}^{\circ} 19.408$, de 18 de novembro de 1930 (no segundo mês do governo provisório de Vargas) e o Confea tinha sido regulamentado pelo Decreto Federal n ${ }^{\circ} 23.569$, de 11 de dezembro de 1933.
} 
Os itens da letra "g" à "k" encontram-se esparsos ou ausentes da lei aprovada em 1937. No item "g" destaca-se a "vulgarização das obras relativas à biblioteconomia", texto que foi chancelado como "vulgarização dos trabalhos relativos à biblioteconomia". A diferença de texto, embora pareça inexpressiva ao leitor mais apressado, esconde uma intenção de que obras e outros materiais de formação de bibliotecários fossem disseminados. Também pode indicar a intenção de Moraes em intensificar a produção de textos formativos para os bibliotecários que não tinham acesso facilitado às produções internacionais, ideia que fica mais clara quando observado o item "h" que determina "Promover intercâmbio com instituições congêneres nacionais e estrangeiras".

Uma das primeiras ações tomadas pelo Conselho Bibliotecário foi a de organizar um cadastro das bibliotecas existentes no Estado. Para isso, o Conselho enviou cartas às bibliotecas do Estado e também a órgãos federais, como, por exemplo, o Ministério da Educação, informando os objetivos do Conselho de Biblioteconomia acrescidas dos dizeres abaixo transcritos:

[...] em cumprimento à letra 'j' da referida lei, o Conselho Bibliotecário está organizando o cadastro das bibliotecas e, para este fim, toma a liberdade de lhe remeter, em anexo, o questionário, para cujo preenchimento solicita o concurso de V. S. Concomitantemente a este serviço, acha-se também o Conselho empenhado em levantar o catálogo dos periódicos existentes nas diferentes bibliotecas e em tempo oportuno, dará conhecimento a V. S. desta resolução. (MAIA, 1937, p. 1)

Embora a duração do Conselho proposto em 1937 tenha sido curta ${ }^{125}$, transcorreu tempo suficiente para a elaboração do "Índice Catálogo Médico Paulista (1860-1936)" e o "Índice Catálogo Médico Brasileiro" (1937-1938) ${ }^{126}$, sob a direção de Jorge de Andrade Maia, que já

\footnotetext{
${ }^{125}$ Como visto no capítulo 3 da presente tese, o artigo 159 da Constituição Federal de 10 de novembro de 1937, combinado ao Decreto-lei federal $\mathrm{n}^{\circ} 24$, de 29 de novembro de 1937, obrigaram os entes públicos de todas as esferas a enfrentarem a questão de redefinirem quais seriam os cargos e gratificações que poderiam ser acumulados pelos funcionários públicos e quais não poderiam. Em resposta a essa situação, no dia 08 de janeiro de 1938 o interventor José Cardoso de Mello Neto publica a exoneração de Jorge de Andrade Maia do cargo de chefe do Catálogo Geral do Conselho Bibliotecário, restando-lhe o cargo de bibliotecário da Faculdade de Medicina. Cf. SÃO PAUlO (Cidade). Secretaria da Educação e Saúde Pública. In: Correio Paulistano. São Paulo, ano 1938, ed. 25102, p. 23, 09 jan. 1938. Disponível em: http://memoria.bn.br/docreader/DocReader.aspx?bib=090972_08\&pagfis=22251. Acesso em: 10 abr. 2021. A exoneração de Maia do conselho bibliotecário seria um indício nas mudanças que viriam a ocorrer nos próximos meses nas instituições bibliotecárias, dentre as quais estaria a Escola de Biblioteconomia, caso abordado no capítulo 4.

${ }^{126} \mathrm{O}$ catálogo foi produção de uma ação conjunta do Conselho Bibliotecário com a Faculdade de Medicina da USP e o patrocínio do Laboratório Andrômaco. Cf. MAIA, J. de A. Índice - catálogo médico brasileiro. In: Correio
} 
havia produzido o catálogo da Faculdade de Medicina da Universidade de São Paulo. Além da publicação de catálogos especializados, houve um empenho em estabelecer uma rede de trocas de acervos, o que no primeiro momento ficou restrito aos periódicos ${ }^{127}$.

O Conselho é regulamentado no ano de 1938, pelo Decreto-lei n. 9.494, assinado pelo interventor Adhemar Pereira de Barros e publicado no Diário Oficial do Estado de São Paulo, no dia 15/9/1938. O documento alterou as exigências para entrada no mercado de trabalho recém-regulamentada.

Dentre as modificações consubstanciais estava a autorização do exercício profissional por bibliotecários com "curso superior OU secundário" [destaque nosso] (art. 13, letra "e"), sem distinção de porte da biblioteca ${ }^{128}$. É possível imaginar que a inclusão dos critérios de desempate, indicando a preferência por candidatos que tivessem títulos universitários, publicações de Biblioteconomia e/ou conhecimentos de maior número de línguas (art. 22), tenha sido incluído no regulamento como tentativa de amenizar a alteração de escopo indicada no artigo acima citado.

Nesse período, o curso de Biblioteconomia, da Divisão de Bibliotecas, já estava em processo de fechamento e a Associação Paulista de Bibliotecários num movimento ativo na sociedade.

\subsection{Associação Paulista de Bibliotecários (APB) e a publicação de materiais sobre bibliotecas}

RBM foi figura-chave para a repercussão da primeira associação profissional de bibliotecários do Brasil, a Associação Paulista de Bibliotecários (APB). Moraes compôs a primeira diretoria da associação, ocupando a posição de diretor. O evento de posse aconteceu

Paulistano. São Paulo, ano 1939, ed. 25.672, p. 23, 12 nov. 1939. Disponível em: http://memoria.bn.br/docreader/DocReader.aspx?bib=090972_08\&pagfis=31643. Acesso em: 10 abr. 2021.

${ }^{127}$ No período em que Moraes esteve na Biblioteca Municipal, era comum realizar a permuta de duplicatas, porém isso ocorreu por iniciativa de cada instituição e sem um sistema próprio que facilitasse este tipo de serviço entre bibliotecas. Com a instituição do Conselho Bibliotecário, firmou-se no Estado um processo facilitado de troca de edições de periódicos, especialmente entre a Biblioteca Municipal dirigida por RBM e as bibliotecas do interior. Correspondências disponíveis no Arquivo Histórico da Biblioteca Mário de Andrade indicam que a Municipal da capital recebia as duplicatas e as distribuía aos interessados que previamente tinham acesso à lista dos números dos periódicos disponíveis.

${ }^{128}$ No ato de criação do Conselho Bibliotecário, havia a abertura para a atuação de bibliotecários sem nível superior, desde que se tratasse de bibliotecas de pequeno porte, mas ainda assim cada caso seria avaliado pelo Conselho Bibliotecário. Cf. SÃO PAULO (Estado). Decreto n ${ }^{\circ}$ 9.494, de 14 de setembro de 1938. Aprova o Regulamento do Conselho Bibliotecário do Estado. Diário Oficial do Estado de São Paulo: São Paulo, Secretaria da Educação e Saúde Pública, São Paulo, 14 de setembro de 1938. Disponível em: https://www.al.sp.gov.br/repositorio/legislacao/decreto/1938/decreto-9494-14.09.1938.html. Acesso em: 20 abr. 2021. 
às 21 h do dia 09 de dezembro de 1938, no restaurante "Trocadero", na capital paulista. É neste nível de detalhes que o evento é narrado pelo jornal Correio Paulistano, do dia 10 de dezembro, dando destaque ao discurso do diretor do Departamento de Cultura, Francisco Pati ${ }^{129}$, cujas declarações são as que seguem abaixo:

[...] Não vejo mérito em se saber onde se acha esta obra, em que parte da estante se esconde aquele volume, em que zona se situam os autores. Mérito existe, e muito grande, em conhecer, não o lugar do livro na estante, mas a posição do seu autor na história do pensamento, a sua importância como contribuição de um espírito à solução dos grandes problemas humanos, o seu valor como realização de arte ou ciência. Mérito existe em orientar o leitor, pondo-lhe às mãos, na hora oportuna, o livro de que necessita e que ele, muitas vezes nem sabe que foi escrito exatamente para esclarecer a dúvida que o aflige. A Associação Paulista de Bibliotecários dá-me a certeza, pelos elementos que a compõem, e, sobretudo, pelo programa que a si mesma se há traçado, de que compreendeu perfeitamente a missão do guardador de livros. Sei que um dos seus principais objetivos é propugnar pela disseminação de bibliotecas em nosso Estado. Mas sei, também que na disseminação de bibliotecas não vê ela um simples pretexto para dar colocação efetiva aos profissionais que a integram com tanto brilho. O seu ideal de ver uma biblioteca surgir em cada cidade brasileira é altamente significativo e patriótico. [...] outra grata certeza que me dão a existência e o funcionamento desta associação, a cuja frente se encontra, agora, o culto espírito de Rubens Borba de Moraes, de quem sou amigo e companheiro de trabalho. Felicito-vos, pois, calorosamente. Tanto pela escolha que fizestes, da nova diretoria que acaba de ser empossada, como pela obra que estais realizando, sem alarde, mas com bastante dedicação e sinceridade. Estas duas virtudes garantem o êxito dos vossos propósitos. Uma associação de bibliotecários, nos moldes desta, é organização digna do mais alto apreço, digna, sobretudo, do apoio e da solidariedade de quantos, na hora atual, exercem, em nossa terra, uma partícula de poder. (ASSOCIAÇÃO, 1938, p. 13 , grifo nosso) ${ }^{130}$

\footnotetext{
${ }^{129}$ Conforme já visto nos capítulos 3 e 4 da presente tese, uma leitura atenta das condições de produção e publicação da notícia em um periódico não pode prescindir da análise do contexto "micropolítico" que auxilia a compreender sua razão de ser. Neste sentido, o tamanho do texto (3 colunas de meia página cada) e o fato de ele trazer um longo trecho do discurso de Pati são indícios de que a notícia estava pensada para que ele se sobressaísse, o que por sua vez permite à pesquisa enxergar, como que por uma breve abertura do obturador da câmara, uma imagem do que outros agentes pensavam sobre o processo.

${ }^{130}$ Embora Francisco Pati trate o empossamento da diretoria como sendo uma "nova diretoria", não há informações sobre uma gestão anterior à de RBM. O jornal indica que a Associação havia sido "recentemente organizada", o que nos faz supor que embora houvesse a mobilização dos bibliotecários, somente em dezembro se oficializou a entidade. No que cabe acrescentar a respeito da APB, encontramos, também no jornal Correio Paulistano, uma nota na seção "Associações" datada de maio de 1936 com uma iniciativa de criação da entidade. Entretanto, é possível supor que tratou-se apenas de uma tentativa, haja vista que não há vestígios, nem mesmo no período, de que tenha tido continuidade naquele ano. Cf. ASSOCIAÇÃO de Bibliothecarios. In: Correio Paulistano. São Paulo, ano 1936, ed. B24579, p. 13, Seção Associações, 05 maio 1936. Disponível em: http://memoria.bn.br/docreader/DocReader.aspx?bib=090972_08\&pagfis=12255. Acesso em: 10 abr. 2021.
} 
O discurso promove um elogio ambíguo da função de bibliotecário, no qual diminui a importância da técnica para exaltar a função intelectual, de mediador do acesso da informação aos leitores. Opera, portanto, sob a lógica de uma divisão de funções que Moraes nunca aceitou - como já visto em sua atuação como professor, diretor de bibliotecas, presidente do Conselho Bibliotecário. Ao mesmo tempo, reconhece o papel fundamental da Associação Paulista e da tarefa que lhe cabe de ampliar a rede de bibliotecas no estado.

Por essa última indicação, definir a missão do bibliotecário como "guardador de livros" e mencionar a preocupação de empregar a todos os portadores de diploma na profissão, tampouco parece muito lisonjeiro, pois reduz as preocupações do grupo de bibliotecários em algo muito menor do que o apelo patriótico mencionado no próprio discurso. Em resumo, sua oferta de apoio político - cifrado na última frase do texto citado - precisaria ser matizado por suas ações pregressas como jornalista que, na década de 1920, coordenou uma campanha difamadora de Mário de Andrade na condição de editor da Folha da Noite, e como diretor do Departamento de Cultura que não moveu dedo para impedir o fim da Escola de Biblioteconomia.

De qualquer modo, merece relevo que Francisco Pati ressalte em seu discurso o que entende ser a relevância da Associação como entidade aglutinadora dos bibliotecários profissionais e também como instituição preocupada com a ampliação na oferta de bibliotecas. Em São Paulo, a APB tornou-se uma instituição que representou avanços significativos do ponto de vista da profissionalização bibliotecária. Foi concebida com a finalidade de “incentivar a difusão de estudos biblioteconômicos e correlatos”, bem como de defender direitos e interesses de classe - portanto, é possível afirmar que parte do que havia sido excluído do provável rascunho de RBM para o projeto de lei 2.839/37, passou a fazer parte da missão da Associação Paulista de Bibliotecários. Por exemplo, integrou-se à sua missão a promoção de eventos em forma de palestras e formações na área. Também era de sua alçada organizar reuniões mensais para estudo e discussão de problemas relacionados à Biblioteconomia.

Moraes, nesse sentido, pregava a necessidade de profissionalização, de constituição e de unificação de classe, como condição de desenvolvimento educacional e cultural, além de condição de desenvolvimento técnico especializado, formação profissional continuada, necessária aos projetos de democratização cultural. A ordem documental não se separava da ordem cultural e educacional, na compreensão da Biblioteconomia Moderna, do bibliotecário modernista. 


\subsection{A Escola de Biblioteconomia vai para a Escola de Sociologia e Política}

Enquanto acumulava alguns avanços e alguns reveses em suas tentativas de fazer avançar e institucionalizar o campo biblioteconômico no estado de São Paulo, Rubens Borba de Moraes estabeleceu uma rede internacional de contatos decisivos para sua trajetória, a partir, especialmente, de viagens aos EUA no final da década de 1930. Uma análise do desenvolvimento do campo da biblioteconomia, no Brasil, não estaria completa sem um olhar para suas relações com o que ocorria no exterior. E RBM vivenciou inúmeras experiências fora do país e procurou implementar por aqui, na condição de diretor da Divisão de Bibliotecas, presidente do Conselho Bibliotecário, entre outras distinções, inovações que ocorriam fora do Brasil, em atitude próxima do antropofagismo defendido por Oswald de Andrade e com quem esteve próximo ainda nos anos 1920.

Nesse sentido, queremos evitar nesta tese certos reducionismos, como, por exemplo, a afirmação de que os cursos de Biblioteconomia, organizados por Rubens Borba de Moraes, eram "compatível[is] com as diretrizes do modelo socioeconômico que influenciara essa aspiração de modernização: o capitalismo norte-americano [...] uma sociedade [que] favorece a divisão do trabalho e a fragmentação das profissões.” (LIMA, 1999, p. 52). Segundo essa visão, os bibliotecários com tal formação teriam "práticas dissociadas dos compromissos essenciais de qualquer profissão, em face das inter-relações que ela deveria manter com a sociedade, muito embora os sujeitos dessas ações as vissem como adequadas porque estão dentro da uniformidade técnica projetada pelo modelo adotado" (LIMA, 1999, p. 53).

Espera-se que o conjunto de capítulos da presente tese já tenha, até este momento, demonstrado suficientemente bem o engajamento de Moraes e do grupo modernista com uma biblioteconomia comprometida com a ampliação das práticas de leitura, tanto na oferta de unidades nos bairros mais populosos quanto no modo como os bibliotecários deveriam pautar suas práticas pelas demandas sociais trazidas pelo público.

Caberia ainda explorar mais profundamente essa relação entre RBM e as instituições estadunidenses de financiamento da pesquisa, evitando-se enxergá-la como via de mão única, isto é, como se os agentes financiadores fossem autores de uma proposta de biblioteconomia que RBM deveria apenas implementar, reproduzindo uma lógica - mesmo que para denunciála - de que a produção de conhecimento é realizada apenas fora do Brasil. A análise de um trecho de um boletim da ALA pode tanto resumir os argumentos a favor dessa lógica quanto expor suas limitações: 
[...] A ALA estabeleceu uma comissão para relações internacionais com o propósito de coordenar o trabalho de vários comitês da Associação engajados em uma variedade de projetos internacionais. Com o suporte financeiro da Fundação Rockfeller essa comissão tem agora um escritório em Washington, onde o seu estabelecimento é essencial porque todo serviço internacional de qualquer tipo deve ser aprovado pelo Departamento de Estado e outras agências federais preocupadas com as relações internacionais, como o Escritório do Coordenador de Relações Inter-Americanas. (ALA, 1937, p. 3)

As viagens que Moraes realiza aos EUA e a manutenção do curso de Biblioteconomia na Escola de Sociologia e Política se faz com verba da Fundação Rockfeller e do Escritório do Coordenador de Assuntos Interamericanos ${ }^{131}$. Isso implica envolvimento direto de RBM com as disputas geopolíticas sobre a América Latina (TOTA, 2000). Ambas as instituições tinham sua razão de existir nos projetos diplomáticos do grupo liderado por Nelson Rockfeller, membro do clã multimilionário proprietário da Standard Oil e, durante a década de 1930, apoiador e comissionado da presidência Roosvelt.

Desde o início de sua carreira profissional, coube a Rockfeller gerir os negócios da família em ramos ativos nos países ao sul do Rio Grande ${ }^{132}$. Seu interesse pelas artes, somado à sua observação sobre as tensas relações existentes entre os funcionários da Standard Oil e as populações locais de onde a empresa se instalava, levou-o a decidir-se pelo emprego do soft power como forma de melhorar a imagem da empresa nos países explorados.

Por essa razão, na década de 1930, Nelson Rockfeller direcionou a fundação "filantrópica" da família para financiar sanitaristas, artistas e missionários atuantes na América Latina. Paralelamente, Roosevelt e sua Secretaria de Estado, passaram a enxergar na América Latina um território de interesse para "ações humanitárias", especialmente no contexto da II Guerra Mundial, por razões de estratégia militar. Em resumo, era mais barato e fácil manter estes países sob sua zona de influência, por meio do estímulo à dinamização econômica e cultural, do que se ver obrigado a combater, às pressas, uma invasão bélica de um grupo indesejável.

Para fazer frente a este desafio, Nelson Rockfeller é chamado por Franklin Roosvelt a integrar o pessoal responsável pela política externa dos EUA, através do Comitê já referido, responsável pela defesa dos interesses deste país na América Latina, a partir de uma abordagem "sutil", sem o emprego da violência do poderio militar - voltado, é claro, para o conflito mundial no qual a participação direta dos EUA era só uma questão de tempo.

\footnotetext{
${ }^{131}$ The office of the Coordinator of Inter-American Affairs (OCIAA), na sigla original em inglês.

${ }^{132}$ Neste caso, refere-se ao rio que faz a fronteira entre EUA e México.
} 
Em outras palavras, o sucesso da estratégia imperialista a la Rockfeller dependia de algum grau de manifestação de apoio a iniciativas que buscassem dinamizar as instituições latino-americanas, trazer-lhes algum progresso em suas condições de vida - combate às doenças, aumento nos índices educacionais, diminuição da pobreza, para ficar em alguns exemplos. É no bojo desse contexto macropolítico que se pode compreender como se dá a negociação do fornecimento de verba estadunidense para os projetos educacionais e culturais, como o de institucionalização da biblioteconomia na América Latina.

Desse raciocínio decorre a conclusão que, por um lado, é inegável a existência de um desejo de controle dos destinos da América Latina e o reconhecimento de que a organização do acesso à informação é parte estratégica deste controle. Por outro lado, havia margem para a negociação de um certo protagonismo dos próprios latino-americanos em seus projetos de transformação, estimulados a encontrar soluções próprias para seus problemas crônicos de desenvolvimento, com a condição de que eles não pusessem em risco a "cooperação" com o "grande irmão do Norte", sem necessidade do uso da força.

Nesse sentido, é que transparece uma voz autoral de Rubem Borba de Moraes na realização de um projeto de biblioteconomia "antropofágico", inclusive na sua relação com os agentes de financiamento dos EUA. Em meio às escaramuças sobre o orçamento da Escola de Biblioteconomia já debatidas no capítulo 4, Moraes recebe, no dia 10 de dezembro de 1938, um convite para uma estadia de três ou quatro meses nos EUA. O convite parte oficialmente da American Library Association (ALA), por meio de seu secretário Carl Milam, e do representante do comitê da ALA para cooperação com a América Latina, Mr. Arthur Gropp ${ }^{133}$.

A mediação do convite é feita por Lewis Hanke, formado em História pela Universidade de Harvard, em 1936. Ao mesmo tempo em que trava relações com Moraes, Hanke começa a trabalhar na "Hispanic Foundation", da Biblioteca do Congresso, onde se manteve por 12 anos. Publicou The Spanish Struggle (A luta espanhola), em 1949, livro em que apresenta uma visão positiva da contribuição dos espanhóis para a colonização da América Latina. Não há possibilidade de se discutir nesta tese sobre um possível etnocentrismo nas conclusões de Hanke; cabe apenas registrar aqui a importância deste autor para os estudos hispano-americanos

\footnotetext{
${ }^{133}$ A esposa de Gropp, como mencionado anteriormente, já havia passado alguns anos no final da década de 1920 na cidade de São Paulo, onde atuara em um curso de biblioteconomia interno aos funcionários da Mackenzie, do qual participou Adelpha de Figueiredo.
} 
no mundo acadêmico dos EUA ${ }^{134}$ e a homologia entre o que afirmava sobre a herança espanhola na América Latina e o que Gilberto Freyre escrevia sobre a herança portuguesa para o Brasil.

Hanke garante a Moraes cobertura total dos gastos de estadia dentro do país ianque, cabendo a Moraes financiar o valor do transporte aéreo. O estágio consistiria em uma etapa inicial de dois meses em uma cidade como Indianápolis, onde ele poderia conhecer uma rede estadual de bibliotecas, apreciar o serviço de referência com catálogo unificado em todo o Estado, empréstimo a domicílio, além de bibliotecas especializadas - sobre negócios, Direito, etc. Depois disso, Moraes passaria cerca de seis semanas para conhecer as principais faculdades de biblioteconomia e as principais bibliotecas do país.

A estadia de RBM nos EUA se dá entre junho e agosto de 1939 e é marcada por viagens de longas distâncias, em trem, muitos contatos em almoços e jantares com bibliotecários do país e, principalmente, visitas a bibliotecas e instituições financiadoras, com alguns objetivos, como o de obter bolsas para si e seus estudantes ${ }^{135}$. A viagem começou pela cidade de San Francisco, onde participou de um congresso da American Library Association (ALA), em que também estiveram presentes representantes de diversos outros países, em sua maioria latinoamericanos $^{136}$.

Nesse encontro, houve duas sessões específicas para a discussão sobre os problemas da cooperação latino-americana com a ALA, na qual se registra a presença de mais de 80 pessoas que ouviram, no dia 22 de junho, de 1939, Rubens Borba de Moraes apresentar, em espanhol, relato sobre as bibliotecas de São Paulo, reportado no ALA Bulletin, sob os seguintes termos:

Dr. Borba de Moraes, dirigindo-se à Assembleia em Espanhol em deferência aos seus colegas hispano-americanos, resumiu o rápido crescimento e centralização dos serviços bibliotecários na Biblioteca Municipal de São Paulo, Brasil. A Biblioteca já pôs em funcionamento uma escola de serviços bibliotecários, a concentração dos materiais bibliotecários, a padronização dos métodos técnicos, a criação de bibliotecas infantis e uma divisão de trocas, e a publicação de uma bibliografia anual. É esperado que ela forme um catálogo

\footnotetext{
${ }^{134}$ Para saber mais, ver: LEWIS Hanke. In: INFOGALATIC: planetary knowledge core. [San Francisco, CA: Wikimedia Foundation, 2015]. Disponível em: https://infogalactic.com/info/Lewis_Hanke. Acesso em: 10 abr. 2021.

${ }^{135}$ Moraes registra em seu diário, no dia 17 de julho de 1929: "O Gilberto consultou-me sobre um homem que Lewis Hanke precisa para trabalhar com ele na biblioteca do Congresso no novo departamento sul-americano. [...] Eu disse ao Gilberto que se a situação em São Paulo continuasse tão desfavorável ao meu trabalho, um lugar como esse seria uma mina para mim, mas que eu teria um dó imenso em deixar meu trabalho em São Paulo pelo meio." (MORAES, 2011, p. 265). Outra anotação relevante está presente no diário, no dia 25 de julho de 1939: "Em Ann Arbor cavei com mr. Leonard 2 bolsas para bibliotecários da Municipal. Ele mostrou a melhor boa vontade de pleitear na Rockfeller o negócio. A impressão de quem assistiu minha negociação é que o negócio está feito." (MORAES, 2011, p. 266).

${ }^{136}$ No relatório do encontro, a transcrição da sessão inicial registra saudações a uma lista de convidados estadunidenses e outros estrangeiros. Nesta última categoria, Borba de Moraes é o primeiro a ser citado, logo seguido por representantes da Venezuela, México, Costa Rica, Chile, Colômbia, África do Sul e Irlanda.
} 
unificado dos acervos das bibliotecas mais importantes de São Paulo. (GROOP, 1939, p. 135) $)^{137}$

No período de quatro meses, isto é, entre fevereiro e junho de 1939, Rubens Borba de Moraes havia vivenciado a derrota em seu projeto de manter a Escola de Biblioteconomia, sob os domínios da Divisão de Bibliotecas, e a vitória simbólica de se ver reconhecido como referência para outros países latino-americanos, presentes na conferência da ALA.

Nessa passagem pela costa leste dos EUA, chamou a atenção de Moraes o modo como as bibliotecas estavam preparadas para atender a uma sociedade em que a leitura, aos olhos dele, era largamente praticada. Em seu diário de viagem, registra uma estimativa de que cerca de $50 \%$ dos 100 mil moradores da cidade de Berkeley eram frequentadores ativos da biblioteca pública da cidade. Moraes considera que o empréstimo doméstico era em grande medida responsável por este feito (MORAES, 2011, p. 256).

RBM passa o mês de julho em visitas às bibliotecas da região dos Grandes Lagos ${ }^{138}$. A paisagem urbana, cunhada pela potência da indústria (especialmente a automobilística), marcava o cenário onde RBM encontraria uma forma de organizar as bibliotecas que, segundo registro de seu diário, possuía pontos em comum com o praticado em São Paulo:

Estou entusiasmado com a organização das bibliotecas americanas. Mais que nunca estou decidido a lutar, a matar gente se for preciso, mas hei de fazer em São Paulo uma biblioteca de verdade! Primeiro passo: dar autonomia à biblioteca. Enquanto nossas bibliotecas forem repartições públicas não teremos bibliotecas. Só peço a Deus que me dê um prefeito amigo (no Brasil tudo se faz por camaradagem) para eu poder emancipar a biblioteca. [...] Passei a manhã na seção de catalogação da biblioteca. Vi uma máquina de copiar fichas Multigraph que vale a pena comprar, o resto é o que fazemos. (MORAES, 2011, p. 261-263).

Os registros do diário de viagem de RBM se alternam entre o deslumbramento com alguns aspectos das bibliotecas norte-americanas, como a sua organização e suas instalações luxuosas, e a indiferença, em relação a outros, como a catalogação, por exemplo, em que "não vê grande novidade". Descrever a situação do país visitado em contraste com a de São Paulo

\footnotetext{
${ }^{137}$ Original em inglês: "Dr. Borba de Moraes, addressing the assembly in Spanish in deference to his Spanish American colleagues, summarized the rapid growth and centralization of library service in the Municipal Library of São Paulo, in Brazil. Already realized in its program is a school of library service, concentration of library materials, standardization of technical methods, creation of children's libraries and a division of exchanges, and the publication of an annual bibliography. It is hoped to form a union catalog of the holdings of the more important libraries in São Paulo." Cf. GROPP, A. E. Latin America, Committee on Library Cooperation with. In: ALA Bulletin, v. 33, n. 11, p. 135-136. 15 out. 1939.

${ }^{138} \mathrm{O}$ roteiro incluiu estadias por Indianápolis, Ann Arbor (arredores de Detroit), Chicago e Cleveland.
} 
serve, mesmo se involuntariamente, para expor a nu as contradições entre o discurso da busca pela modernidade no país e as práticas efetivas, vigentes na administração pública paulista/nacional, cuja cultura política dos anos 1920 e 1930, por exemplo, continuavam marcadas pela herança colonial, entranhada na vida do país.

Moraes afirma que a diferença entre a biblioteca de lá e a de cá é que a primeira possui uma autonomia que aqui não temos. Todavia, enxergar na aliança com o chefe do executivo municipal a solução para o problema, implica partir, desde o nascedouro, de uma estratégia que nega o próprio objeto de desejo. Se os bibliotecários municipais dependem de um "favor" para poderem atuar adequadamente, a autonomia desejada acha-se comprometida de partida.

A contradição demonstra os embates a que estão sujeitos os projetos do modernista, em contexto marcado por fortes heranças coloniais, em realidade marcada pelo que Canclini chamou de "modernismo sem modernização" (CANCLINI, 2003). Nesses termos, trata-se, portanto, de compreender a herança do patrimonialismo (FAORO, 2001) e as influências deixadas na administração das coisas públicas. E tirar a conclusão de que a mudança da relação socialmente estabelecida entre, por exemplo, o público leitor e as bibliotecas anda pari passu com outras transformações estruturantes na sociedade, como o reconhecimento do direito à cultura letrada por toda a sociedade, condição prévia de democratização cultural, e não simplesmente a personalidade do chefe da burocracia que gerencia os serviços públicos, no caso, as bibliotecas.

Dito de outra forma, a autonomia buscada por RBM só seria possível mediante transformações da sociedade em múltiplos aspectos, dentre eles, alterações quantitativas e qualitativas dos diferentes setores políticos e sociais com a cultura letrada e suas instituições, das práticas letradas consideradas por todos como direito, com condições de serem efetivamente exercidas. É fato que exigir de RBM, em um Brasil de 1939, mergulhado em estado crônico de analfabetismo, de insuficiência escolar, de parque editorial em afirmação e centralizado, talvez fosse anacronismo. Ainda assim, enxergar os limites de sua visão e atuação permite a nós compreendermos, neste século XXI, contradições que certamente herdamos do projeto de Biblioteconomia Moderna levada adiante pelos modernistas e com as quais ainda convivemos ainda hoje. Por outro lado, é também modo de aprendizagem e de apropriação da herança deixada, indispensável à superação ao avanço em direção a novas formulações e novas contradições que, certamente, a "era da informação" e a globalização provocaram e vêm provocando.

Durante a viagem em análise, RBM participa de um Congresso para latinoamericanistas na Universidade de Michigan, também financiado pela Fundação Rockfeller. 
Nesse evento, Moraes estreita laços com Gilberto Freyre e Lewis Hanke, ambos eruditos, interessados nos passados coloniais da América Portuguesa e Espanhola, respectivamente. Freyre e Hanke encontraram em Borba um bibliotecário bibliófilo que lhes poderia auxiliar com pistas de livros raros para colecionar e ler nas bibliotecas dos EUA. Por esse motivo, Moraes foi escolhido, junto com William Berrien, para efetivar decisão importante do Congresso: elaborar um trabalho bibliográfico das obras raras sobre o período colonial do Brasil, tarefa satisfeita em parte pela publicação do Manual Bibliográfico de Estudos Brasileiros, cuja primeira publicação data de 1949.

Com esta lista de contatos com instituições e personalidades do mundo bibliotecário dos EUA, Moraes havia se gabaritado para se tornar mais independente das vicissitudes resultantes das disputas locais, vividas na Prefeitura Municipal de São Paulo. A súbita interrupção da Escola de Biblioteconomia do Departamento de Cultura, no primeiro semestre de 1939, seria secundada por sua retomada em outra instituição, a Escola de Biblioteconomia, associada à existente Escola Livre de Sociologia e Política.

É possível encontrar algumas pistas sobre o cotidiano dessa nova escola, em documento de 1943 (Escola de Biblioteconomia - Quinto ano letivo, 1943). Há, ali, além de um histórico, uma cronologia do curso que confirmam a Escola Livre de Sociologia e Política como a continuadora da experiência anterior, permitida pela subvenção da Fundação Rockfeller, atribuída em $1942^{139}$.

Uma comparação entre os nomes dos cursos, dos docentes e dos programas revela que Rubens Borba de Moraes continuava sendo o lente da matéria de História do Livro; a bibliografia, os temas e a sequência de aulas permaneciam os mesmos do curso oferecido entre 1937 e 1938. Mais do que repetir a análise já realizada em item anterior da presente tese, cabe apontar que o projeto de Biblioteconomia permanecia fundamentalmente o mesmo. A matéria de "Catalogação e Classificação" continuava sendo oferecida por Adelpha de Figueiredo e a matéria de "Organização e Administração de Bibliotecas" ficava a cargo de Francisco José de Almeida Azevedo, um dos poucos homens formados na turma de $1938^{140}$ e bolsista do Departamento de Estado dos EUA, junto com a outra professora do curso, Maria Leonor

\footnotetext{
${ }^{139}$ Fay (1943) descreve: "The ALA has been asked to administer a five-year grant for the development of the library school in São Paulo, Brazil. The school will be under the direction of Rubens Borba de Moraes, director of the Municipal Library.” Cf. FAY, L. ALA, Good Neighbors. Books Abroad, v. 17, n. 2, p. 118, 1943.

${ }^{140}$ FORMATURA dos bibliotecários do Departamento de Cultura e professorandas da Escola Normal "Padre Anchieta”. In: Correio Paulistano, ano 1938, ed. 25395, São Paulo, p. 1, 21 dez. 1938. Disponível em: http://memoria.bn.br/DocReader/Hotpage/HotpageBN.aspx?bib=090972_08\&pagfis=27196\&url=http://memoria .bn.br/docreader\#. Acesso em 10 abr. 2021.
} 
Voigtlander ${ }^{141}$. Na matéria de organização das bibliotecas, Azevedo inclui temas novos como a Documentação, de Paul Otlet, e de procedência europeia.

Esses fatos, somados à manutenção do currículo durante toda a década de 1940, tornam questionável a tese de que o ensino da FESP, nos anos 1940, se caracterizou por uma matriz exclusivamente tecnicista. Este raciocínio precisaria ser matizado pela percepção de que se buscou incluir temas e literatura que abrissem a perspectiva de uma formação também pautada pela erudição, ao menos enquanto Rubens Borba de Moraes foi o diretor da escola.

Em 1944, Moraes se transferiu para a Biblioteca Nacional. As razões oficiais apresentadas para esta movimentação incluíam a necessidade de reorganizar seu gigantesco acervo. Para a literatura sobre a história da biblioteconomia, a data serve como marco de uma vitória do "tecnicismo norte-americano" sobre a formação "humanística". Em item futuro, discutiremos essa avaliação; antes, porém, é mister demarcar outro momento importante para a trajetória de Rubens, e que ajuda a explicar seu chamado ao Rio de Janeiro: o discurso sobre "o problema das bibliotecas brasileiras".

\subsection{RBM manifesta sobre "O problema das bibliotecas brasileiras"}

Em 1943, RBM é convidado por Arquimedes de Melo Neto e Amelia de Queiroz Carneiro de Mendonça, ambos do Departamento Cultural da Casa do Estudante do Brasil, para proferir uma palestra no Salão de Conferências da Biblioteca do Ministério das Relações Exteriores do Brasil (Palácio do Itamarati), sob a presidência de Carlos Drummond de Andrade. O evento aconteceu no dia 23 de setembro do mesmo ano, e Moraes expôs na ocasião sua visão sobre "O problema das bibliotecas brasileiras". Transcrita, sua fala foi publicada no mesmo ano pela própria Casa, com prefácio de Gilberto Freyre ${ }^{142}$.

A palestra de RBM foi programada para compor um ciclo de conferências que incluíram Afonso Arinos de Melo Franco, Gilberto Freyre, Mário de Andrade e Viana Moog. A inclusão do bibliotecário Rubens Borba de Moraes nesta série de palestrantes conceituados é indício de uma consideração de Moraes como um intelectual intérprete do país em pé de igualdade com nomes ilustres, como os mencionados, ao mesmo tempo que indica a importância maior atribuída às questões de que se ocupava.

\footnotetext{
${ }^{141}$ The Department of State Bulletin, Volume III (1940), p. 282.

${ }^{142} \mathrm{O}$ texto viria a ser republicado duas vezes: 1) no Boletim Bibliográfico da Biblioteca Mário de Andrade, v. 42 , n. 1, p. 9-21, jan/mar 1981; 2) em formato de livro, no ano de 1983, pela Associação dos Bibliotecários do Distrito Federal, com apresentação de Antônio Agenor Briquet de Lemos e adição do "Discurso de abertura do $8^{\circ}$ Congresso Brasileiro de Biblioteconomia e Documentação”, proferido por Rubens em 1975.
} 
RBM aproveitou a ocasião para fazer uma radiografia das bibliotecas brasileiras, bem como para lançar um verdadeiro manifesto, conclamando a mobilização geral pela causa bibliotecária. O discurso previamente preparado seguiu o tom dos movimentos da época que buscavam analisar e explicar problemas culturais Brasileiros. A insistência com que Moraes indicou que as questões apresentadas por ele mereciam ser estudadas e incluídas em planos de ação estruturados, demonstra a sua preocupação em deixar claro que os cursos de Biblioteconomia, reunindo saberes técnicos especializados e cultura geral, eram fundamentais ao desenvolvimento de sistemas de bibliotecas sólidos para o país.

Em sua explanação, procurou demonstrar a necessidade de pautar suas críticas no tempo e no espaço, por vezes trazendo dados históricos comparativos entre a relação biblioteca e sociedade na Europa e nos Estados Unidos ${ }^{143}$. Nesse sentido, enfatizou que a mentalidade bibliotecária do Século XIX era de que os ricos provinham bibliotecas para os pobres, num ato de filantropia. Entretanto, mudanças estruturais no século XX fizeram com que os americanos construíssem uma relação entre sociedade e biblioteca, numa primeira vista, mais promissora do que a dos europeus e dos brasileiros. Destaca o fato de que nos Estados Unidos o povo teria reivindicado bibliotecas.

Embora Moraes não tenha levado seu discurso para as explicações das particularidades histórico-culturais de cada país, é possível observar que alguns aspectos remetem à compreensão da biblioteca como serviço público. Moraes associa o sentido da biblioteca como direito de cada cidadão e ressalta que serviços do equipamento cultural devem responder às demandas dos seus públicos.

Moraes toma uma referência de uso comum no passado europeu, para negá-la: "abrir uma biblioteca não é mais fechar uma prisão” (MORAES, 1943, p. 17). Segundo ele, não se deve aplicar juízos de valor ético à abertura de dispositivos culturais, como se eles fossem os responsáveis por assegurar a correção moral dos seus usuários. Procura, com isso, demarcar uma diferenciação entre o otimismo pedagógico e cultural que elevava a "instrução pública" e o acesso à cultura à condição de "salvadora da pátria"144.

$\mathrm{Na}$ Educação, a escola era vista como instrumento capaz de, sozinha, salvaguardar o país do atraso cultural. Para Moraes, o fato de as bibliotecas terem entrado para as políticas públicas, nos anos 1930, indicou uma superação da necessidade de conscientização do papel

\footnotetext{
${ }^{143}$ Moraes, segundo Lemos (1983), foi pioneiro em problematizar a Biblioteconomia brasileira e a realizar um estudo de Biblioteconomia comparada.

${ }^{144}$ Para entender o que é "otimismo pedagógico", cf.: NAGLE, J. Educação e sociedade na primeira república. São Paulo: Editora Pedagógica e Universitária, 1976.
} 
social destes dispositivos culturais. Lembra que, no período do Segundo Reinado, a idealização de cidades como centros de cultura dependia do interesse benemérito de Barões ou fazendeiros que viam nesta ação um modo de sustentação de seu status social. A Biblioteca se fiava na existência de fortunas pessoais dedicadas à sua existência, sem uma política pública que as preservasse dessa instabilidade.

Partindo de uma análise histórica panorâmica, Moraes afirmou que há uma mudança de direção ao apontar para o reconhecimento do papel educacional e cultural das bibliotecas. A partir dos anos 1930, diferentes atores da sociedade (governo, estudantes, intelectuais, professores e cidadãos comuns) passaram a perceber a importância das bibliotecas e defender a abertura dos acervos para o livre acesso. Apesar dos avanços, subsistiam alguns problemas: as bibliotecas eram idealizadas como espaços de conservação cultural ou, na nomenclatura empregada por Perrotti (2016), constituíam-se sob o modelo da biblioteca templum.

Para falar com franqueza, as nossas bibliotecas não são bem bibliotecas. São ainda, em geral, depósitos de livros, mais ou menos organizados, bem ou mal conservados. Não tem a função ativa que deviam ter. Os livros estão trancados; pouquíssimas bibliotecas brasileiras permitem o livre acesso às estantes. Os catálogos, quando existem, são todos feitos por métodos empíricos e antiquados. As poucas exceções só servem para confirmar a regra geral. A prova está no espanto e na alegria que sente o leitor quando utiliza uma dessas bibliotecas modernas. Esse estado de coisas precisa acabar. É aí que cabe a intervenção do poder público. (MORAES, 1943, p. 26)

Severo em suas críticas, RBM junta em sua análise críticas sobre as bibliotecas brasileiras, suas experiências, estudos em livros e viagens pela Europa, Estados Unidos e Brasil. Deixa claro que a divisão entre biblioteca para o povo e biblioteca para a elite era o que o incomodava no modelo europeu, no qual se formou (MORAES, 1943). Ao mesmo tempo em que demonstra que as bibliotecas norte-americanas não fizeram essa separação:

As bibliotecas americanas nasciam, pois, sem o erro básico das europeias: a separação de bibliotecas para o povo e bibliotecas para as elites. Elas não eram ali, doadas por uma classe como uma esmola a outra classe menos favorecida. (MORAES, 1943, p. 16)

Ao longo do discurso, Moraes deixa transparecer a acepção do conceito de sociedade moderna do período. Há um reconhecimento dos indivíduos como sujeitos livres e iguais, o que postula uma visão de que para que o país se modernizasse seria necessário a modernização das relações entre os sujeitos, entendidos, por sua vez, como autônomos em seu próprio desenvolvimento. A ideia é construída sobre o lema de que só haverá um Brasil moderno se as 
relações sociais e culturais se modernizarem. É dentro desse arcabouço que surgem, segundo ele, em diferentes partes do país, projetos políticos voltados para as bibliotecas, para os livros e para a leitura.

Moraes avalia que o principal entrave para a expansão das bibliotecas não estava nem no número de unidades, nem em sua disposição geográfica e nem sequer no fornecimento de acervo. Neste último caso, em especial, o Instituto Nacional do Livro estaria fornecendo às "bibliotecas perdidas no interior [...] lotes de livros", salvaguardando-as do olvido das autoridades locais (MORAES, 1943, p. 20).

Ao mesmo tempo em que celebra a existência de um mercado nacional de livros em expansão, sob o beneplácito do investimento estatal a assegurar, em uma ponta, a rentabilidade do comércio de livros e, do outro, o acesso à leitura a populações que de outra forma permaneceriam esquecidas, Rubens Borba aponta para a falta de bibliotecários preparados, com equilíbrio entre o domínio das técnicas modernas de biblioteconomia e da erudição demandada a um intelectual:

O bibliotecário moderno, repito, é um intelectual e um técnico. A cultura, ela a adquire em primeiro lugar, antes de entrar para a escola técnica, na Universidade e fora dela, lendo e estudando os conhecimentos humanos em perpétua transformação. É por isso que julgo um erro colocar à frente das bibliotecas não só eruditos sem preparo técnico, mas também técnicos sem erudição. O meio de remediar esse mal é atrair para as escolas de biblioteconomia, o intelectual, o universitário, o estudante que terminou seu curso superior. É dessa matéria-prima que são feitos os verdadeiros bibliotecários. Para a carreira bibliotecária, nova entre nós, cheia de futuro, é preciso atrair o jovem entusiasmado e de boa vontade, que procura, em falta de melhor caminho, essas superlotadas carreiras chamadas, não sei por que, de liberais. (MORAES, 1943, p. 22, grifo nosso)

Na passagem acima, Moraes explora um aspecto que pode ajudar a explicar o que talvez o tenha levado ao trabalho na Biblioteca Nacional. Era preciso reorganizá-la, dar novo formato a seu curso de formação, num país que pretendia transformar-se. A Biblioteca Nacional já fora objeto de sua reflexão em 1942, quando produziu um relatório com sugestões de mudança no curso; Moraes voltaria novamente à carga no Palácio do Itamarati, ao afirmar que o curso da BN tivera impacto nulo fora da capital federal. A título de comparação, cita o trabalho do Departamento Administrativo do Serviço Público (DASP) ${ }^{145}$, que criou um centro de

\footnotetext{
${ }^{145}$ A criação do DASP pelo governo Vargas, em 1937, é um indício de que o Estado estava migrando da lógica patrimonial para a lógica da racionalização administrativa nas repartições públicas. Para saber mais, ver Rangel (2017).
} 
aperfeiçoamento e formação, de modo a propiciar a criação de uma rede de bibliotecas e bibliotecários em âmbito federal.

A insistência com que Moraes exige a formação em grau superior, previamente ao ingresso na formação em Biblioteconomia, não é nova e vigora ainda tanto na Europa, como nos Estados Unidos, ao lado de outros modos. Ela pode ser vista como uma forma de negociação entre seu projeto de modernização e uma realidade arcaica, da qual ele via a impossibilidade de escapar. Tratava-se de evitar um círculo vicioso: para garantir a ampliação do direito de acesso à leitura, era preciso investir em bibliotecas dignas do nome. Para tal, era preciso formar bibliotecários, eles próprios leitores. Isso seria possível apenas tomando-se como "matériaprima" pessoas que tivessem o nível de formação à altura da exigência da tarefa. Da mesma forma, profissionais que, ao se apropriarem das técnicas especializadas, já possuíam repertórios culturais capazes de propiciar uma articulação e reflexão sobre as demandas funcionais de organização da biblioteca e sua natureza de instituição cultural, a serviço de valores civilizatórios avançados.

A proposta esbarrava, evidentemente, nas condições concretas sociais, educacionais e culturais do país. Faltava contingente humano para o preenchimento de tais funções, ou seja, quadros com formação superiores, dado que o acesso à leitura (condição sine qua non) para atingir este nível era incrivelmente restrito. RBM pugnava por um projeto de democratização cultural e de profissionalização que no Brasil dos anos 1930 e 1940 acabava se encerrando em parcelas restritas das classes médias urbanas mais abastadas, sem vazão nas profissões ditas "liberais". Nesse sentido, a realidade acabou impondo caminhos que acabarão caracterizando a Biblioteconomia moderna brasileira como um campo profissional predominantemente feminino, para onde se dirigiram estratos da classe média escolarizada que se identificavam com questões educacionais e culturais e que começavam a irromper como força social e profissional no espaço público moderno, a exemplo do que, em certo sentido, acabou ocorrendo também, apesar das variações, em outras partes do mundo. As questões de gênero, assim como outras, ocupam assim, um papel privilegiado e a ser explorado por outras pesquisas acerca dessa transição entre a Biblioteconomia clássica e Biblioteconomia moderna, da mesma forma que as condições de subalternidade reservada às mulheres na sociedade brasileira não deixam de indicar o lugar social que seria atribuído ao campo pela ordem social prevalente ainda hoje no Brasil, a despeito dos esforços e tentativas, como as de RBM, de alçá-lo a níveis compatíveis com o de outras áreas profissionais e de conhecimento tidas como superiores.

O discurso no Palácio do Itamarati marca um dos pontos mais altos da carreira de Rubens Borba de Moraes, ao menos no âmbito de sua atuação dentro do país. Permite enxergar, 
também, os limites de suas formulações, dentro das constrições impostas pela realidade em que viveu, por sua forma de agir e de pensar em alternativas de ação. Não obstante estas limitações, visíveis a posteriori para nós estudiosos do século XXI, também cumpre observar que o discurso de RBM surtiu um efeito inquietante e significativo. Em 1945, ele seria convidado a dirigir a Biblioteca Nacional.

\subsection{Moraes assume a Biblioteca Nacional}

Em 17 de dezembro de 1945, Rubens Borba de Moraes é nomeado para o cargo de Diretor da Biblioteca Nacional ${ }^{146}$, do Ministério da Educação e Saúde, "vago em virtude da aposentadoria de Rodolfo Augusto de Amorim Garcia ${ }^{147}$. Desde agosto do ano anterior, ainda sob o governo Vargas, Moraes era responsável pela Divisão de Preparação da Biblioteca Nacional. Em março de 1945, havia assumido a disciplina de bibliografia e serviço de referência no curso fundamental de Biblioteconomia da Biblioteca Nacional. A entrada de Moraes na direção da instituição gerou manifestações de intelectuais, políticos, educadores e pesquisadores nacionais e internacionais que enviaram cartas a ele e escreveram artigos de opinião para jornais ${ }^{148}$.

Moraes trazia consigo a preocupação com a formação de bibliotecários especializados, bandeira levantada quando estava no Departamento de Cultura. Antes mesmo de ser nomeado como professor no curso fundamental de Biblioteconomia da Biblioteca Nacional ${ }^{149}$, colaborou com um "exame crítico do projeto feito para reorganização do curso de Biblioteconomia da Biblioteca Nacional" ${ }^{150}$. Em 1945, lamentou que a formação de bibliotecários pela BN (depois

\footnotetext{
${ }^{146} \mathrm{O}$ cargo de Diretor da Biblioteca Nacional era um cargo em comissão, padrão "P", do quadro permanente do Ministério da Educação e Saúde.

${ }^{147}$ NOMEAÇÃO. 17 de dezembro de 1945. Disponível no acervo pessoal de RBM.

${ }^{148} \mathrm{O}$ historiador americano, Lewis Hanke, amigo de Moraes, escreveu uma carta para parabenizá-lo pelo novo cargo e lançar-lhe um desafio: "você tem uma grande oportunidade diante de você de estabelecer bibliotecas e biblioteconomias com bases sólidas no Brasil". Correspondência de Lewis Hanke datada de 1945. Disponível no acervo pessoal de RBM na BBM.

${ }^{149}$ A partir da Reforma de 1944, a Biblioteca Nacional passou a ter dois cursos de Biblioteconomia. Um deles era intitulado de "Curso Fundamental de Biblioteconomia" e preparava auxiliares de biblioteca. Entre as disciplinas constava: 1) Organização de Bibliotecas; 2) Catalogação e classificação; 3) Bibliografia e referência; 4) História do livro e das bibliotecas. No curso superior em Biblioteconomia, as disciplinas eram: 1) Organização e administração de Bibliotecas; 2) Catalogação e classificação; 3) História da literatura (aplicada à bibliografia); 4) Disciplina optativa: 4.1 Noções de paleografia e catalogação de manuscritos e de livros raros e preciosos; 4.2 Mapotecas; 4.3 Iconografia; 4.4 Bibliotecas de música; 4.5 Bibliotecas infantis e escolares; 4.6 Bibliotecas especializadas e bibliotecas universitárias; 4.7 Bibliotecas públicas ou 4.8 Qualquer disciplina da Faculdade Nacional de Filosofia ou Instituto Congênere. Cf.: DIAS, A. C. Na Biblioteca Nacional. Chronos: publicação cultural da UNIRIO, v. 1, n. 10. Rio de Janeiro: UNIRIO, 2015.

${ }^{150}$ Correspondência de 4 de novembro de 1942 enviada por Maria P. de Brito a RBM em agradecimento pela análise. Documento disponível no acervo pessoal de Moraes.
} 
da reforma de 1944) não atendesse às necessidades internas da própria biblioteca, a qual exigiria especialistas. O assunto foi tema de conversas e correspondências trocadas com o Ministro da Educação. Logo que tomou posse, Moraes reclamou:

Os bibliotecários e bibliotecárias são nomeados mediante concurso e, com a
finalidade de formar candidatos capazes, o governo mantem uma escola de
biblioteconomia com a denominação de 'Cursos da Bibl. Nac'. As matérias
ministradas nos referidos cursos são exclusivamente biblioteconômicas,
tais como: catalogação, classificação, bibliografia e organização de
bibliotecas. Para ingresso nos cursos é exigido apenas o término do curso
secundário. Embora sejam essas matérias as disciplinas básicas para o
treinamento de bibliotecários para o trabalho rotineiro em bibliotecas públicas
em geral, não são suficientes para a formação de pessoal especializado em
certos serviços particulares existentes numa biblioteca do tipo de nossa
Nacional. [...] ora para catalogar, estudar, e oferecer esse material ao
público é necessário dispor de pessoal competente e capaz com base
cultural sólida e especializada. É com pesar que o confessamos: a biblioteca
Nacional não dispõe desse pessoal em número suficiente. [...] A Biblioteca
Nacional via-se, na falta de pessoal competente, privada de cumprir a mais
simples de sua[s] funções culturais: a catalogação de seu acervo ${ }^{151}$.
(MORAES, 1945, p. 1, grifo nosso).

É possível observar no trecho citado que Moraes associava a atividade de catalogação a uma atividade intelectual que demandava "conhecimento geral", o que, segundo ele, os bibliotecários formados na própria instituição não dispunham devido à baixa exigência para ingresso no curso. A solução encontrada por ele foi a de contratar historiadores para a catalogação de acervos, que, segundo ele próprio, estavam já havia quinze anos sem ser catalogados.

As críticas de Moraes teriam apenas começado. Ao observar que não teria força política para encampar as mudanças que julgava necessárias, estabeleceu uma parceria com a Rockefeller que, em função disso, enviaria bibliotecários para a BN para fazer um diagnóstico da situação da biblioteca ${ }^{152}$. O objetivo principal da parceria era que a ALA enviasse dois consultores estrangeiros para a BN, custeados pela Rockfeller, para que emitissem um relatório sobre as condições do acervo, prédio e serviços da biblioteca. Com a vinda dos consultores estrangeiros, RBM pôde argumentar com descrições de especialistas os problemas encontrados na Biblioteca. O documento abordou aspectos físicos e materiais, como as condições de

\footnotetext{
${ }^{151}$ MORAES, R. B. de. [Correspondência]. Destinatário: Gustavo Capanema. São Paulo, 1945.

${ }^{152}$ A parceria entre Biblioteca Nacional, Rockfeller e ALA - American Library Association, resultou em grande investimento, sem honorários para os cofres públicos. Cf. MORAES, R. B. de. Relatório do diretor da Biblioteca Nacional ao ministro da Educação e Saúde, relativo ao exercício de 1946. 1946. In: Revista de Biblioteconomia, Brasília, ano 2, n. 2, p. $203-231$, jul./dez., $1974 . \quad$ Disponível em: https://periodicos.unb.br/index.php/rbbsb/article/download/28645/24916/. Acesso em: 20 abr. 2021.
} 
armazenamento do acervo: higiene, ventilação, iluminação, proliferação de traças e outras ameaças biológicas. Além disso, alertava sobre a dificuldade de desenvolver melhorias na biblioteca com os funcionários mais antigos da casa, pautados por uma visão de biblioteconomia tradicional e burocrática, como aquela que RBM já havia enfrentado em São Paulo, com Eurico de Góes.

A experiência da Biblioteca Nacional pode ser cotejada com a da Divisão de Bibliotecas do Departamento de Cultura. Tanto em São Paulo como no Rio de Janeiro, a ação de RBM consistiu no entrecruzamento de dois feixes de preocupações. A primeira delas consistiu em desalojar o que considerava como velhos hábitos de uma concepção de biblioteca e de bibliotecário, cujo foco estaria na preservação dos documentos; a segunda, em criticar rotinas de trabalhos nas quais o usuário/leitor estava longe de figurar como elemento central. Era um convicto defensor da Biblioteconomia Moderna, ainda que distinguisse a importância da preservação do patrimônio cultural representado pelas obras do passado guardadas nas Bibliotecas Nacionais.

A reorganização do acervo, no caso da $\mathrm{BN}$, consistiu em tarefa de magnitude incomparavelmente superior à da Biblioteca Municipal Mário de Andrade, mesmo levando-se em consideração que para esta foi necessário planejar e construir um novo prédio, processo eivado por disputas com outros órgãos da Prefeitura Municipal, de onde resultou uma alteração no projeto formulado inicialmente por Moraes. O tamanho do acervo, sua visibilidade e sua importância histórica como patrimônio cultural elevaram em muito o desafio de Moraes. Ainda assim, o objetivo era o mesmo: facilitar o acesso ao leitor, tanto o comum como o pesquisador do patrimônio.

Ao mesmo tempo em que enfrentava esse desafio, RBM também se ocupou da reconstituição do curso de Biblioteconomia da $\mathrm{BN}$ e apresentou um projeto para a criação de um sistema de bibliotecas nos bairros populares do Rio de Janeiro, então capital federal. A relação entre estas bibliotecas públicas e a Nacional se daria nos mesmos moldes do proposto no Regulamento do Departamento de Cultura, em 1936. A Biblioteca Nacional teria função de servir como espaço de pesquisa. Nos bairros seriam instaladas as "bibliotecas populares" que abririam as portas do saber aos operários e outros trabalhadores, às novas gerações, abrigadas em suas necessidades de suporte no processo escolar.

$\mathrm{Na}$ intenção de trazer a modernidade às bibliotecas da capital federal, Rubens Borba de Moraes não pôde ter Mário de Andrade como apoio a seu lado, pois Mário já havia regressado a São Paulo, com condições de saúde difíceis, mantendo-se fora de combate. É interessante observar, contudo, que Moraes mantivera sua fidelidade a aspectos dos projetos que os uniu 
nos anos 1930, posição que tem sido pouco abordada pela literatura biblioteconômica, ou seja, a luta por um projeto cultural de dimensão federal e nacional, que conferisse reconhecimento social e político à Biblioteconomia no país. Pródiga na abordagem desse período pela chave de leitura da aplicação da classificação decimal de Dewey ao acervo da BN, a literatura da área deixa escapar, com essa abordagem reduzida à sua dimensão técnico-especializada, o sentido da preocupação sociocultural com a implantação de um sistema de classificação documentário na Nacional, assim como a dimensão político-cultural dos diferentes sistemas de organização documentária e da informação, pedra de toque das transformações defendidas por Moraes durante o período em que esteve à frente da $\mathrm{BN}$.

A proposta de formação de uma rede de bibliotecas "populares" não teve sucesso, também, na capital federal e pode indicar outro elemento na interpretação central a esta tese. Novamente, o esforço modernizante dos agentes no campo da biblioteconomia tem sua métrica de sucesso condicionada à adaptação às estruturas de reprodução dos arcaísmos brasileiros, que convivem e atravessam as tentativas de mudanças. Para modernizar a BN, um espaço em grande medida restrito às elites de pesquisadores e eruditos, Moraes encontrou a sustentação política necessária, embora não estivesse imune a críticas de contemporâneos, algumas delas posteriormente reproduzidas pela bibliografia.

Já no momento em que seu projeto toca as balizas do projeto de revolução conservadora (FERNANDES, 1975), sua ação se vê obstruída, mesmo se o capital social disponível por Moraes sempre lhe permitiu, pessoalmente, escapar, em alguma medida, de certa forma "honrosa", dos impasses vividos. No caso de São Paulo, o clima sufocante do Departamento de Cultura, após a saída de Mário de Andrade, e também a frustração com a interrupção dos planos de expansão da rede de bibliotecas, foi em parte superada pela ampliação dos vínculos profissionais com o exterior, o estágio nos EUA, em 1939; o problema da interrupção da formação de bibliotecários pela Prefeitura foi compensado pelos ares frescos da Escola Livre de Sociologia Política, com apoio da Fundação Rockfeller.

\subsection{Nem "clássica", nem "moderna": "empenhada" e "antropofagista"153}

Para concluirmos a análise documental proposta nesta tese trataremos de um dos últimos discursos públicos de RBM, antes de sua saída do Brasil para trabalhar na ONU em Nova York.

\footnotetext{
${ }^{153}$ Optamos pelo termo antropofagista, no sentido indicado por Isac Teixeira Assunção e que, segundo ele, tratarse-ia de distinção cunhada por Antonio Candido "para dissociar a significação de antropófago, que é comedor de carne humana". Nesse sentido, antropofagista "seria, sim, o comedor da cultura estrangeira" (ASSUNÇÃO, 2010).
} 
O evento ocorreu em setembro de 1947, foi organizado pela ALA e contou com a presença de bibliotecários de diversas nacionalidades da América Latina. Moraes, impossibilitado de participar presencialmente do encontro, devido às atividades da Biblioteca Nacional, enviou, como sua porta-voz, a Sra. Maria Luiza Monteiro da Cunha ${ }^{154}$ que leu texto escrito por ele, na segunda sessão geral do evento, ocorrida no dia 15 de setembro de 1947.

Moraes começou seu discurso recordando que, em 1939, ano em que esteve pela primeira vez em um evento da ALA, teve um período de aprendizagem, tanto nas bibliotecas europeias, quanto nas discussões promovidas pela instituição americana. Em suas próprias palavras define as experiências que teve:

\begin{abstract}
Oito anos atrás, nesta mesma estação do ano, nesta mesma cidade, participei de uma reunião anual desta mesma Associação Americana de Bibliotecários. Passei os melhores dias daquela reunião discutindo problemas de nossa profissão, lucrando com sua longa experiência profissional e obtendo prazer com a extraordinária capacidade americana de conhecer pessoas e fazer amigos. Senti aqui um clima de entusiasmo, de fé no futuro e de confiança no nosso trabalho que me encheu de coragem para voltar e lutar pelas bibliotecas do meu próprio país. Se os resultados de minhas conversas com vocês tivessem sido reunidos, eles teriam preenchido um livro sobre a ciência do serviço bibliotecário. Pouco antes dessa visita aqui, passei vários meses visitando as bibliotecas da Europa. Lá, encontrei alguns dos bibliotecários mais sábios e cultos que já conheci. Se minhas conversas com aqueles homens tivessem sido gravadas, elas teriam preenchido um livro sobre a filosofia das bibliotecas. (MORAES, 1947, p. 1, grifo nosso)
\end{abstract}

No início de sua fala, Moraes pontua a Biblioteconomia em duas vertentes: a da "ciência do serviço bibliotecário" e a da "filosofia das bibliotecas”. Não há oposição ou hierarquização entre "ciência" e "filosofia". Há, outrossim, diferenças: a Biblioteconomia nos EUA é pensada como "serviço", algo que pode remeter para a centralidade do leitor e a necessidade de um método de trabalho científico como necessidade para cumprir tal tarefa. São inúmeros os leitores e suas demandas e só lançando mão da "ciência" é possível fazer algo diante de tanta diversidade; por outro lado, a Biblioteconomia europeia estaria voltada mais para a memória

\footnotetext{
${ }^{154}$ Maria Luiza Monteiro da Cunha foi funcionária da Biblioteca Pública Municipal de São Paulo no período em que RBM foi diretor; também foi sua aluna na primeira turma do curso de Biblioteconomia da Escola de Sociologia e Política, em 1940. No momento do evento, a bibliotecária estava concluindo o mestrado em Biblioteconomia na Columbia University com bolsa da ALA. Logo que concluiu a pós-graduação, retornou ao Brasil e assumiu a disciplina de "Catalogação" do Curso de Biblioteconomia da Escola de Sociologia e Política, antes ministrada por Adelpha de Figueiredo. Na década de 1960, quando Maria Luiza da Cunha trabalhava como diretora da Biblioteca Central da Universidade de São Paulo, juntou-se ao comitê que estruturou a Escola de Comunicações e Artes (ECA). Em 1966, foi criado o curso de Biblioteconomia da ECA que ficou sob sua responsabilidade. Como parte do primeiro corpo docente do curso ministrou as disciplinas de "Introdução à Biblioteconomia" e "Catalogação". Para saber mais, ver o artigo de Fujita; Macedo (1992).
} 
acumulada, os conhecimentos impressos nas coleções guardadas séculos após séculos nas bibliotecas.

Esse trecho inicial prepara, todavia, explicitação que será feita adiante e que traz o argumento central da fala de Moraes. Está em pauta a necessidade de superação da dualidade estabelecida entre erudição (Biblioteconomia Clássica) e conhecimento técnico (Biblioteconomia Moderna). Como vimos anteriormente, Moraes defende um ideal de bibliotecário que faz a síntese entre os dois termos, que tenha domínio de conteúdos culturais amplos, assim como a qualificação técnica especializada necessária para realizar os "serviços bibliotecários". Cultura e técnica em seu entender são elementos essenciais para que as instituições culturais cumpram com efetividade seu papel no mundo moderno

Na sequência de seu discurso, Moraes apresenta sua leitura sobre as transformações no período entre 1939 e 1947. Segundo ele, o contexto de 1947 é bastante distinto do de 1939, especialmente no que diz respeito às relações culturais internacionais. A partir de referências do que seriam as consequências da herança dos dois conflitos bélicos - pois a II Guerra Mundial seria em grande medida resultante dos desarranjos institucionalizados pela "Grande Guerra" Moraes trata de problemas mundiais a serem resolvidos, no pós-guerra, por cada nação dos participantes daquele Congresso.

Em seu discurso, RBM projeta um público espectador constituído majoritariamente por estadunidenses que, segundo ele, deveria transformar sua visão sobre a América Latina. Os habitantes do continente americano, abaixo do Rio Grande, são descritos como "selvagens a serem catequizados", visão corrente provinda dos colonizadores europeus que precisa ser mudada, Ironicamente, RBM refere-se à instabilidade europeia, capaz de provocar dois conflitos bélicos altamente destrutivos, algo que nenhum morador do Novo Mundo jamais teria experimentado. Era preciso, assim, que os antigos missionários fossem "convertidos", para deixarem de crer em algo que seria uma "paz armada, paz que não é real”, sobretudo por haver ainda países que se consideram culturalmente melhores do que outros, com privilégios a exigir exclusividade no direito de se manifestarem (MORAES, 1947, p. 3).

Esta explanação sobre o que pensa ser a realidade social de seu tempo é feita no intuito de questionar o papel que eles próprios, na condição de bibliotecários, podem exercer no mundo, com o objetivo de impedir a eclosão de uma terceira guerra mundial:

Para onde essa política nos levará? Para a guerra, sem dúvida. É possível para nós, bibliotecários, ficar de braços cruzados - catalogar nossos livros enquanto esperamos por uma bomba que destruirá nossa biblioteca? O que podemos fazer, você pergunta. Acredito que podemos fazer muito. Nós, bibliotecários 
e todos os trabalhadores intelectuais em geral, cometemos um grande erro. Esse erro foi nos isolarmos em nosso trabalho, ocuparmo-nos exclusivamente nos aspectos técnicos de nossos trabalhos. Um livro passou a ser principalmente um problema de catalogação e circulação. Não pensamos o suficiente sobre a influência que este livro pode ter na sociedade. Nossa missão era divulgar a cultura. Hoje devemos nos preocupar com o uso que as pessoas farão dessa cultura. (MORAES, 1947, p. 2, grifo nosso)

Moraes lança um olhar crítico sobre a política que vinha norteando os trabalhos bibliotecários nos anos anteriores à Segunda grande guerra e problematiza a identidade do bibliotecário, ao denunciar que a classe profissional tem se fechado em seus problemas de "catalogação e circulação", atuando de forma isolada e desconectada das repercussões da leitura sobre os leitores. A compartimentação da realidade complexa (MORIN, 1999) em "minimundos" que não se comunicam, implica esquecer que os problemas têm uma dimensão planetária - assim como suas soluções - e que precisam ser encarados politicamente e com abrangência global.

Da constatação do problema, Moraes lança um manifesto na tentativa de que os bibliotecários entendam que sua participação no meio social global precisa ser objetivada nas rotinas diárias, nos discursos, nos encontros anuais, nas políticas bibliotecárias concretas:

[...] Vivemos em um mundo de política - mas nós, bibliotecários, temos um horror inato à política. Eu acredito que este é mais um dos nossos erros. A influência política em uma biblioteca é uma coisa ruim e ninguém vai negar isso. Contra tal intervenção, devemos sempre lutar. Mas existe outra forma de política que é a arte de prever as consequências dos atos humanos e de orientá-los para que sejam úteis à sociedade. E é essa forma de política que devemos praticar.

Estamos em uma posição excepcionalmente boa para saber o que está acontecendo no mundo. Temos livros e revistas em abundância e ninguém está em melhor posição para descobrir a verdade imparcial. Falta-nos, no entanto, a vontade de nos determos nesses fatos e de proceder a interpretá-los. Chegou o momento em que os técnicos devem pensar nas consequências humanas das técnicas. Chegou o momento em que devemos pensar além das técnicas. (MORAES, 1947, p. 2, grifo nosso)

A crítica à ingerência política nas bibliotecas, possivelmente eco da experiência vivenciada por Moraes no Departamento de Cultura em São Paulo, não se confunde, todavia, com a neutralidade do bibliotecário, ao contrário. A experiência, embora curta, em São Paulo, demonstrou para ele que havia um grande potencial transformador, político e social, neste dispositivo cultural, ao ser pensado como instituição viva, dinâmica e criativa. Todavia, para realizá-lo, as bibliotecas teriam que se relacionar com lógicas exteriores ao campo, mas não poderiam ser pautadas por elas. Como instâncias culturais, elas são dotadas de lógicas próprias 
e singulares, específicas aos fenômenos culturais. Apesar de inscritas e relacionadas com a ordem social, bibliotecas têm que se afirmar como organismos autônomos, categoria que remete à esfera política. Por isso, os bibliotecários, queiram ou não, exercem uma atividade intrinsecamente política, pois atuam em dinâmicas que se organizam em torno de um bem público por excelência: a cultura. É nesse sentido que é preciso não só catalogar e difundir cultura, pois "Chegou o momento em que os técnicos devem pensar nas consequências humanas das técnicas. Chegou o momento em que devemos pensar além das técnicas" (MORAES, 1947, p. 2).

Esta mesma passagem também continua a desenvolver uma superação do binômio, apresentado anteriormente, ciência/filosofia, ao insistir no fato de que pensar além das técnicas - isto é, na dimensão política transformadora implícita às bibliotecas -- demandaria um olhar político sobre o lugar e o peso desta instituição cultural nas suas relações com a sociedade, um novo paradigma envolvendo ciência e fillosofia, em relações dinâmicas.

Continuando sua exposição, RBM lança a ideia de militância bibliotecária, ao defender que os bibliotecários se engajem na política definida como a "arte de prever as consequências dos atos humanos e de orientá-los para que sejam úteis à sociedade”. Em referência ao problema enfrentado pela diplomacia estadunidense previamente a 1942, quando titubeou entre defender um dos lados em conflito ou permanecer neutro, Moraes continua:

[...] NÃO há lugar no mundo de hoje para o isolacionista. [...]. Para o bibliotecário de hoje, há um trabalho que convoca homens de boa vontade e fé - a política da paz. Temos hoje a missão de mostrar que vários modos de vida e pensamento podem coexistir pacificamente (MORAES, 1947, p. 2, grifo nosso).

A militância para uma "política da paz" consistiria em "mostrar que vários modos de vida e pensamento podem coexistir pacificamente". Tal argumentação conduz à compreensão da biblioteca como elemento central para a apropriação das culturas locais/nacionais/internacionais e, tal apropriação, como antídoto, trincheira contra a possibilidade de uma terceira guerra mundial, algo que representaria uma hecatombe nuclear.

Nessas circunstâncias, o termo biblioteca recebe um sentido amplo, compreendido como "lugar" de manifestação e respeito à memória de diferentes povos, com seus modos de vida singulares, sem hierarquizações como sempre ocorreu, com os projetos coloniais que estabeleceram a superioridade cultural e civilizacional do colonizador. Ao bibliotecário é atribuída, assim, a responsabilidade de atuar como agente que compreende a importância de 
coexistência das diferentes culturas, com suas distintas origens temporais e geográficas, e o respeito aos múltiplos modos de "ser e estar no mundo".

O cotejamento do discurso de RBM com as ações da Divisão de Bibliotecas anteriormente discutidas nesta tese permite afirmar que Moraes reverberou no discurso de 1947 a ideia dos modernistas paulistas segundo as quais a "biblioteca" não se resume a organismos culturais, sem vínculos com a ordem política e social onde se encontram. Seu isolamento não permite transformar um povo que, no caso brasileiro, era ainda, em sua maioria, analfabeto. Tais transformações, na concepção de Moraes, colocam em jogo articulações e dinâmicas complexas que só a própria articulação dinâmica entre técnica, política e cultura, entre saberes e fazeres práticos e intelectuais, entre tempos e espaços culturais diversos e distintos é capaz de realizar.

Do ponto de vista de que nos ocupamos aqui, ou seja, da direção que círculos modernistas brasileiros buscaram imprimir à formação do campo da Biblioteconomia, no Brasil, temos, portanto, uma proposta de Biblioteconomia que não seria nem europeia ou estadunidense, nem clássica ou moderna, mas busca de superação dessas tradições que ecoaram no país, mas ganharam filtros locais, em comunhão com o ideário de reafirmação identitária do Brasil.

As relações vitais de Moraes com o modernismo paulista, sua participação ativa nas revistas Klaxon (1922) e Terra Roxa e Outras Terras (1926) e ainda na revista Antropofagia (1928), pontas de lança do ideário modernista, se articulam com a defesa de uma Biblioteconomia que ia além da cópia, seja da Europa, seja dos Estados Unidos. Seu pronunciamento no Congresso da ALA é indicação da busca de superação, da tentativa de originalidade que permeou a formação da Biblioteconomia brasileira. A partir de distintas matrizes e tradições, RBM e porção significativa dos círculos modernistas brasileiros, sobretudo aquela identificada com posições antropofagistas e interessadas na problemática das bibliotecas e da Biblioteconomia, atuaram, na falta de uma melhor definição, para a constituição de uma "Biblioteconomia antropofagista", empenhada não só na constituição do campo técnico e especializado, como também em sua qualificação e autonomia políticas.

Tal como reivindicado por modernistas partidários da antropofagia literária, RBM propunha, portanto, no Congresso da ALA, uma direção que colocasse a Biblioteconomia em novo patamar, nem europeu, nem norte-americano, nem clássica, nem moderna - antropofágica. Buscado e gestado em sua longa experiência de sujeito ligado a diferentes mundos e que aprendera na prática a importância de colocá-los em articulação, o "modelo antropofagista" correspondia não só a episteme voltada à realização dos anseios de jovens em conflito com seus 
contextos privilegiados de origem. Proposto em país que travava uma luta histórica por autonomia e afirmação no concerto das nações, tal modelo era uma forma de saída para os impasses da guerra, modo de estar em relação com a alteridade, a cultura do outro, sem deixar de ser si próprio, de ser singular na pluralidade. Num mundo conflagrado, após o desastre que conduziu ao horror nuclear de Hiroshima e Nagasaki, a antropofagia poderia ser caminho promissor, abertura a novas direções.

Se a proposta de Moraes oferecia, no Congresso da ALA, uma alternativa ao campo biblioteconômico fechado num impasse entre a "filosofia" e "a ciência", ao mesmo tempo afirmava sua fidelidade à causa modernista. Em 1924, um de seus vários manifestos, o PauBrasil, apelava para um sentido de dupla direção, nas relações políticas e culturais internacionais: "Dividamos: poesia de importação. E a Poesia Pau-Brasil, de exportação" (ANDRADE, 1924, p. 5). Se transpusermos para o campo biblioteconômico tal máxima, teríamos: "Dividamos: Biblioteconomia de importação. E a Biblioteconomia Pau-Brasil, de exportação".

A proposta de Moraes apresentada no evento da ALA foi defendida quando ele se encontrava ainda na Biblioteca Nacional, tentando efetivá-la na prática. Como era de se esperar, suscitou resistências que não eram somente culturais e que RBM tenta vencer, lançando mão da ajuda de especialistas americanos, autoridades externas cuja expertise poderia colaborar para levar adiante seus projetos de renovação da Nacional. Isso não aconteceu, todavia, pois a reforma da Biblioteca não era um problema técnico ou administrativo, mas político-cultural, envolvendo disputas por posições e projetos de país defendidos por diferentes atores e grupos. A Biblioteconomia antropofagista de Moraes foi, assim, combatida na capital do país, como já ocorrera em São Paulo, com Prestes Maia e o Estado Novo. A praça da Cinelândia, mais que um ambiente de paz, tornou-se, assim, um território de guerra que expulsará RBM para fora do país, tal como aconteceria anos depois com jovens inconformistas que, mesmo pertencendo a meios não necessariamente populares, não cabiam no mundo brasileiro ainda dominado por relações de força que vinham do passado colonial e da nova situação de Guerra-fria, pós 1945. Nova Iorque será, assim, espécie de exílio, a terra de um recomeço. Contratado pela Organização das Nações Unidas, RBM assume, em 1948, a Biblioteca do órgão criado em 1945; cargo que ocupa até 1949, ao ser nomeado diretor do Centro de Informações da ONU, tendo que mudar-se, então, para Paris, onde fica até 1954, para voltar, então, à Biblioteca da ONU, em Nova Iorque, como seu diretor, cargo que ocupará até sua aposentadoria, em 1958.

Ao retornar ao Brasil, RBM engajou-se na Universidade de Brasília, em 1963, onde terá uma atuação destacada como professor do curso de Biblioteconomia, até retirar-se para seu 
sítio, na cidade de Bragança Paulista, onde falece, em 1986. A ida à recém-criada Brasília, e que durará de 1963 a 1970, é indício que permite conjecturar que a luta pelo campo biblioteconômico, nos termos por ele delineados na participação no Congresso da ALA, precisa ser fortalecida, estava ainda a ser feita, assimilada pelo país. RBM não se rendera à tendência funcional, operacional que, apesar de avanços pontuais do campo, vinha se impondo à Biblioteconomia. A formação das novas gerações de bibliotecários se dava, no seu entendimento, em crescente direção tecnicista, contrária ao "modelo antropofagista" representado por ele e que estava na origem da constituição de um campo social e político específico. Era importante, assim, continuar a luta pela formação de bibliotecários capazes de articular "ciência" e "filosofia", técnica e cultura, saber especializado e erudição, condição de afirmação e estabilização, de reconhecimento do campo biblioteconômico não apenas oficial, mas pela sociedade brasileira em sua diversidade. Era, portanto, preciso continuar defendendo, no Brasil, uma Biblioteconomia e bibliotecários empenhados e antropofagistas, como fizera no Congresso da ALA. 


\section{CONSIDERAÇÕES FINAIS}

Os deslocamentos culturais e sociais de RBM permitiram-nos observar que a institucionalização da Biblioteconomia no Brasil emergiu no bojo de tentativas de mobilização social em torno da cultura, entendida pelos modernistas como elemento fundante para o Brasil "moderno". A construção social do campo da Biblioteconomia brasileira passou por um processo de profissionalização e de construção de identificação social da biblioteca que até então era lida sob uma perspectiva patrimonialista, por sua função de guarda da memória social pelas dinâmicas que ordenavam a biblioteca e a colocavam dentro de matrizes excludentes social e culturalmente.

Com RBM, a Biblioteconomia se organiza em torno de uma causa: a modernização do país. Vemos que a história de constituição do campo é complexa, a começar por sua institucionalização e, por isso, não pode ser reduzida por leituras dualistas que apresentam oposição entre técnica e "humanismo".

Ao olharmos para as práticas bibliotecárias desempenhadas por RBM, vemos que sua posição sobre as Biblioteconomias não exclui as duas orientações predominantes nas práticas espalhadas pelo mundo, antes, as contém e, em certo sentido, as supera, ou seja, a luta para conciliar técnica e humanismo o fez ultrapassar a dualidade que vigora ainda hoje em discursos sobre a Biblioteconomia, em vários circuitos especializados ou não. Uma das marcas importantes dessa preocupação é que Moraes optou por não realizar traduções dos documentos da ALA (originalmente em inglês) para a língua portuguesa. Ele entendia o que significava a circulação de ideias e um dos objetivos do "plano bibliotecário" modernista, por ele representado, era, em primeiro lugar, que a memória cultural fosse organizada para circular, para que os sujeitos pudessem entrar em contato com ela e, por esse caminho, se renovassem e a renovassem. Nisso, o projeto modernista foi inovador. Não era um projeto de simples ordenação documentária, face à explosão documentária decorrente, especialmente do desenvolvimento das técnicas de reprodução; era, antes, uma ação político-cultural que pretendia colocar a ordem bibliográfica a serviço do processo civilizacional e da superação de amarras coloniais que impediam o país de afirmar-se no cenário das nações ocidentais avançadas. Moraes buscou na política da boa vizinhança encontrar o suporte técnico necessário para colocar o plano bibliotecário em ação. Os acordos firmados com a ALA ao longo dos anos nos indicam como Moraes associou a adoção de técnicas então modernas de catalogação e classificação com concepções de bibliotecas centradas na circulação dos acervos, na sua disponibilização e usos, como condição de afirmação de uma nova ordem histórica no Brasil. 
Rubens Borba de Moraes sabia que o utilitarismo era uma tendência crescente da modernidade e que, nesse cenário, não se tratava apenas de modernizar a ordem dos livros, mas sim de colocá-la em sintonia com novos modos de se colocar na sociedade.

A Biblioteconomia fecundada por RBM no projeto da Divisão de Bibliotecas do DC almejava a organização de uma classe profissional com atuação ativa na construção de uma sociedade livre dos desmandos impostos pela ordem colonial. Para isso, fundamentou-se no conhecimento histórico sobre a formação do país e na realidade social e cultural das pessoas de seu tempo. O projeto de Biblioteconomia apostou na sistematização e capilarização dos saberes bibliotecários, por meio da formação de profissionais oriundos de diversas partes do país. Podemos dizer que os modernistas vislumbravam a participação dos bibliotecários na mudança estrutural do cenário político reinante, o que confere uma marca especial ao processo de constituição do campo, no Brasil. Vemos surgir uma Biblioteconomia "empenhada", nos termos que Candido aponta como característica da formação da literatura, no Brasil (CANDIDO, 1969), sua grandeza e, ao mesmo tempo, seu limite.

Dado que o projeto bibliotecário em constituição estava empenhado em participar da construção de uma sociedade moderna, é decorrência natural o esforço em problematizar o paradigma bibliotecário da conservação de acervos, que reduzia o papel da biblioteca a depósitos de memória e de conhecimento produzido no mais das vezes na Europa.

Quais foram os agentes desse projeto de biblioteca? Como foi possível que a sociedade brasileira e, em especial, a cidade de São Paulo produzisse indivíduos cujas trajetórias particulares os levassem a pensar no papel das bibliotecas e dos bibliotecários, a partir da superação da dicotomia entre técnica e humanismo? Como deu-se a inclusão da Biblioteconomia nas agendas das políticas públicas locais e nacionais? Um mergulho pela biografia de Rubens Borba de Moraes ajuda a elucidar questões fundantes que estão na formação do campo biblioteconômico no Brasil e a compreender seu desenvolvimento, enquanto território de disputas e de contradições que atravessam sua história e a caracterizam até o presente em suas errâncias entre técnica e cultura.

Ao resumir em Testemunha ocular o que foi sua passagem por Genebra, RBM a sintetiza em um conjunto de tensionamentos: a cidade que é orgulhosa das liberdades individuais, também possui uma tradição férrea em que nada parece se alterar; o rapaz que tinha vocação para o desregramento também era fascinado pela ascese necessária para quem 
desejasse conhecer o máximo possível de livros, como o fazia ${ }^{155}$. Desse conjunto de tensões nasce um "autorretrato com palavras" que serve como mote para estas considerações finais:

Revoltei-me contra tudo que é estável e não quer evoluir. Revoltei-me contra o burguês satisfeito com o que aí está, contra esse 'burguês', que nós queríamos destruir nos tempos da Semana de Arte Moderna. Revoltei-me contra o poder do dinheiro e acabei desprezando-o e ignorando-o. Aprendi a desconfiar do capitalismo. Mas não é impunemente que se vivem tantos anos debaixo da bandeira vermelha e amarela da cidade de Calvino. Alguma cor desbotou em mim. Minha índole levava-me, naturalmente, a ser um intelectual boêmio. Mas Genebra interveio e me fez levar essa vida, porém, com conforto. Ao contrário da generalidade dos brasileiros que vivem despreocupados de suas obrigações, adquiri, para sempre, um senso agudo do dever, do cumprimento das tarefas que me cabem. Adquiri uma fé inabalável na democracia sem nivelamentos. Vi como a democracia verdadeira não é uma questão de igualdade, mas de oportunidades iguais para todos. Aliás, Stálin disse que a igualdade é um preconceito burguês. Aprendi essa porção de princípios genebrinos bons e bonitos. Nem sempre, porém, os pude praticar rigorosamente, porque a carne é fraca e a carne do brasileiro é fraquíssima. (MORAES, 2011, p. 93)

Dentre os deveres aos quais se obrigava, Moraes inclui a defesa da democracia, entendida como a promoção de oportunidades iguais para todos e não como um igualitarismo. Isso representa, na passagem da juventude para a velhice, uma confisssão de mudança de visão política, pois no mesmo livro Moraes declarou ter trazido aos amigos modernistas, logo de sua chegada ao Brasil, a leitura de autores comunistas como Henri Barbusse e que se declarava um socialista na época, influenciado por leituras de Marx, Engels, Kautsky, Plekhanov, entre outros.

A mudança de perspectiva teria se dado quando Stálin ascendeu ao poder - em 1923, após a morte de Lênin. Tais mudanças de opinião são correntes na vida de um intelectual atento às transformações do mundo e, sem prejuízo de sua importância, explicam menos sua trajetória do que os paradoxos e contradições que o definem.

Rubens Borba de Moraes assume certos paradoxos como seus, mas tem dificuldade de enfrentar outros que igualmente ajudam a iluminar sua atuação como bibliotecário e, por tabela, auxiliam a compreender a formação do campo bibliotecário. Por exemplo, sua invocação do

\footnotetext{
${ }^{155}$ No mesmo livro, Moraes afirma que em seus dois últimos anos de Genebra teria lido a impressionante marca de cem livros por ano, incluindo-se aí o tempo gasto com as anotações de leitura registradas em um caderno que teria se perdido com o tempo. Mais importante do que confirmar o número exato de livros devorados por Moraes é expressar seu anseio por mostrar-se como um bibliófilo que, antes de tudo, lê e se apropria dos livros, o que confere novo sentido ao ato de comprá-los e colecioná-los.
} 
princípio liberal clássico de estimular a "igualdade de oportunidades" e negar o igualitarismo, em convívio com sua desconfiança do capitalismo e sua revolta contra o poder do dinheiro.

De sua formação europeia, Moraes traz o princípio liberal da "igualdade de oportunidades", aplicável em uma sociedade como a genebrina, na qual a modernização conduziu a uma diminuição das desigualdades sociais e pôde ser observada e vivida por ele. Entretanto, falar em "igualdade de oportunidades" assume sentidos radicalmente distintos para a experiência social paulistana e brasileira, resultante do processo de modernização conservadora que amplia a produção de excedentes de riqueza apropriados por um número crescentemente menor de pessoas (FERNANDES, 1975).

Moraes não formula a questão nestes termos, mas antevê a necessidade de adaptações quando afirma que se revoltou contra o poder do dinheiro e aprendeu a desconfiar do capitalismo. O que ele pensaria se estivesse ainda vivo neste início do século XXI, com a ampliação da visibilidade e do questionamento de questões como o machismo e o racismo estruturais da sociedade brasileira? Se a leitura de Testemunha ocular traz a impressão de que Moraes não conseguiu superar, no sentido dialético, o conflito de pertencimento a dois mundos: de um lado, o europeu, onde se formou; e de outro, o brasileiro, onde vive e onde estão suas origens, como membro de uma família abastada. Seu projeto bibliotecário é, nesse aspecto, tentativa de síntese entre situações e condições que se mostrariam historicamente irreconciliáveis, como indicam os crescentes conflitos de várias ordens da sociedade brasileira ao longo do tempo. E, aqui, em especial, entra a institucionalização da Biblioteconomia como campo socioprofissional.

Na década de 1920, a carência de dispositivos culturais promotores da mediação da experiência social paulistana era patente para diversos dos grupos sociais envolvidos, como demonstra a iniciativa de reforma e ampliação da Biblioteca Municipal, em 1926. O relativo fracasso dessa reforma da biblioteca é representativo das limitações desse projeto de biblioteconomia no qual a preservação do patrimônio se transforma em um fim em si mesmo. Em tal projeto, o bibliotecário possui como preocupação principal manter uma política que não leva em consideração as demandas da população em termos de acesso à memória preservada nas bibliotecas e de ressignificação destes espaços, em flagrante contradição com as transformações sociais e culturais vividas de forma pioneira no Brasil por cidades como São Paulo, mas que viriam a se espalhar, com suas regionalidades, por todo o território nacional nas décadas seguintes.

A necessidade de adaptação às situações emergentes por meio das mudanças políticas impôs a necessidade de fortalecer e definir o posicionamento dos atores envolvidos na 
"problemática da biblioteconomia". Nessas condições se intensificaram as tensões que envolveram diferentes lógicas de pensamento sobre o que deveria ser a Biblioteconomia moderna. Desse modo, o campo bibliotecário passou a viver um momento de fortificação e consolidação. Nesse sentido, ganharam forças políticas as ações e projetos que coincidiam com a oferta de profissionais capacitados para atuarem na estruturação do país, no que diz respeito à organização da documentação da administração pública e estatal. Os efeitos práticos dessa direção está representado no surgimento do IBBD - Instituto Brasileiro de Bibliografia e Documentação, em 1954, idealizado pela bibliotecária Lydia Sambaquy e que o presidiu nos anos de 1954 e 1965. Segundo Oddone (2006, p. 45), “os serviços prestados pelos bibliotecários do IBBD sob a liderança de Lydia Sambaquy abriram um novo campo de ação profissional”. Houve, assim, um deslocamento conjuntural da Biblioteconomia pública para a Documentação, representada pelo IBBD que, segundo Sambaquy (2020, p. 13) tinha por objetivo "promover o intercâmbio de informações entre as instituições de pesquisas e divulgar, no Brasil e no estrangeiro, os trabalhos técnico-científicos brasileiros". Campos que se entrecruzam, a Biblioteconomia e a Documentação, tornam-se, no entanto, disciplinas distintas que, no universo comum de que participam, representam projetos e modo de atuação complementares, mas distintos, ligados, especialmente, às questões da informação científica e tecnológica (ICT); a Documentação acaba disputando territórios comuns com a Biblioteconomia; disputa que se tornará mais acirrada com o surgimento da Ciência da Informação, em que pesem as declarações de complementariedade e de colaboração entre os campos. No Brasil, com forte histórico de exclusões e fraturas culturais, o campo das ações político-culturais voltadas para as bibliotecas públicas, entendidas como instituições formativas e não somente informativas, empenhadas na universalização da leitura e da aculturação letrada, ficam prejudicadas diante das urgências científicas e técnicas implicadas diretamente nos projetos de Documentação e de Ciência da Informação.

Ao observarmos a posição na qual ficou a biblioteca municipal de São Paulo, identificamos que as práticas de leitura se alinharam ao Departamento de Cultura - a ponto de na década de 1940 oferecerem em conjunto, com a consonância da Divisão de Bibliotecas, um curso de Biblioteconomia voltado para professores e interessados em trabalhar em bibliotecas escolares e infantis. Os defensores destas práticas de leitura possuíam, todavia e em graus diversos, fissuras em seu interior. O cotejamento das aulas de RBM e Adelpha de Figueiredo demonstra o mútuo reconhecimento da coexistência de várias biblioteconomias nesse período. (Ainda nesse sentido, se pudéssemos acrescentar o nome de Lenyra Fraccaroli, veríamos que o modo como ela define as relações entre biblioteca e escola também resulta em uma terceira 
vertente de definição da biblioteconomia). É possível lançar a hipótese de que as divisões em seu próprio seio dificultaram a consolidação da Biblioteconomia como campo de estudos e práticas sociais, educacionais e culturais.

Outro momento em que se objetivaram as divisões do campo foi a participação de Fidelino de Figueiredo no processo de cancelamento da Escola de Biblioteconomia do Departamento de Cultura. Fidelino de Figueiredo instituiu um lugar para si dentro do campo de disputas que se colocava por meio das políticas de Prestes Maia. Enquanto RBM foi até aquele momento o anunciador de um campo em mudança e expansão, Fidelino de Figueiredo atuou como árbitro, legitimando-se por meio de uma pretensa formação intelectual voltada para as bibliotecas e tornando-se assim essencial para posicionar ou destituir a prefeitura do papel de formador cultural. Após essa decisão do poder público municipal, instaurou-se neste âmbito uma disputa entre a Cultura e a Educação. Se na gestão de RBM o campo social da Biblioteconomia contava com atores de diferentes frentes, como a Educação, o Legislativo, o Municipal, o Estadual e o Federal, com o cancelamento caiu por terra os pressupostos alimentados até aquele momento.

Embora anacronicamente possamos analisar tais disputas com desconforto, podemos indicar que a configuração adotada pelo campo profissional, a partir dos anos 1940, granjeoulhe visibilidade justamente por compreender as demandas enunciadas pelos administradores do Estado. Se, por um lado, as medidas foram importantes para a visibilidade profissional, não podemos deixar de nos perguntar: qual profissional? Que biblioteca? Quais as consequências para o desenvolvimento de um país plural, cultural e social? O que priorizamos e o que perdemos com tudo isso?

As respostas a tais perguntas precisam, necessariamente, passar pelo legado que os modernistas nos deixaram, não apenas em termos do que foi feito, mas também daquilo que foi derrotado.

Andrade e Moraes frequentaram a Biblioteca Pública Municipal de São Paulo nos anos 1920, no qual o paradigma vigente era o da biblioteca templum (PERROTTI, 2016). O mesmo ocorria na maioria das bibliotecas existentes no país neste período: em detrimento do acesso ao conhecimento ali armazenado, prezava-se pela guarda do acervo como bem patrimonial intocável. Em acréscimo, quando se tratava de uma biblioteca "pública" isso era, via de regra, a expressão da fonte de financiamento de sua manutenção e não uma expressão da função social do dispositivo cultural.

"Público", neste caso, significava mantido com recursos estatais, dentro de uma gestão patrimonialista que confunde o que é do Estado com os bens pessoais dos ocupantes dos postos- 
chave na administração deste Estado (FAORO, 2001). O patrimonialismo arraigado na gestão pública na cidade de São Paulo dos anos $1920^{156}$ pôs em estado de choque um jovem idealista, apaixonado por livros e recém-chegado de uma experiência social radicalmente distinta (como é o caso de Genebra) chamado Rubens Borba de Moraes.

De forma semelhante, o choque atingiu também outros jovens apaixonados por livros, sedentos por mudanças e, ao menos em certos casos, sensíveis às dores de sofrerem alguma forma de exclusão social. Para a sorte deles (e do Brasil), as famílias de Mário de Andrade e Rubens Borba de Moraes se conheciam, e os dois logo se fizeram amigos e companheiros de projetos. Nosso embate por democracia cultural, protagonizada pelos bibliotecários, se alimenta também de lances históricos de sorte, em que os deuses regentes dos acasos nos sorriem.

As travas de uma Biblioteconomia clássica, em afinidade com uma gestão patrimonialista da coisa pública, não se encerram na sua dificuldade de lidar com um público cada vez maior, mais diversificado e portador de maiores demandas (educacionais e sociais). Encontra-se também na incapacidade de lidar com a revolução editorial, decorrente dos distintos impactos de outra revolução - a Industrial - no mundo dos livros, da imprensa, da leitura de uma forma geral.

O livro possui uma relação ambígua com a produção industrial (CHARTIER, 1999), que em todos os aspectos torna mais complexo o trabalho do bibliotecário. Por um lado, os avanços na tipografia tornam o livro reproduzível em larga escala e disponibiliza a um número crescente de leitores, em escala mundial, a produção bibliográfica outrora restrita a uma circulação reduzida em termos geográficos. Sem alterar o fetiche provocado pelas edições primeiras ou especiais da obra, o trabalho do bibliotecário aumentou pelo simples fato de que há mais títulos disponíveis no mercado, aumentando a oferta de leitura e os interessados (tanto leitores como editores) em dar vazão a esse aumento industrial da oferta.

Por outro lado, a autoria do livro permanece algo artesanal, irreprodutível, inimitável. Há mais títulos no mercado, mas cada título é único. Adelpha de Figueiredo se referiu a esse fato, na sua aula de 1935, como o "exército de autores anônimos"; seguindo os passos de Moraes, podemos afirmar que o papel do bibliotecário é retirá-los do anonimato, dar-lhes conhecimento público através do reconhecimento do que eles têm de específico em termos de estilo, de temática, de abordagem.

Voltadas para a preservação, as bibliotecas públicas patrimonialistas reforçavam o status quo de excluir da cultura letrada a maior parte da população; além disso, apartavam-se de

\footnotetext{
${ }^{156}$ Desnecessário lembrar que a localização desta experiência é apenas uma necessidade argumentativa; o patrimonialismo se espraia por toda a história do Brasil, em todo o território.
} 
mudanças estruturais necessárias para lidar com a revolução editorial. Do século XIX em diante, no caso da Europa, ou dos anos 1920 em diante, no caso do Brasi1 ${ }^{157}$, torna-se obrigatório fazer a seleção do que deve ser preservado.

No bojo do processo de seleção, estão incluídos tanto a decisão do que deve ficar nas prateleiras da biblioteca, o que implica na necessidade de ler e compreender para estabelecer critérios para selecionar, quanto mediar o conhecimento do leitor sobre as novidades que aparecem nas prateleiras da biblioteca; informar-lhe das opções de leituras preservando-lhe o direito de escolher livremente seu próprio percurso como leitor. O bibliotecário incapaz de efetuar ambos os processos atrai para sua biblioteca a "desordem empírica insustentável”.

Vivenciando esse momento histórico, Moraes problematiza as relações estabelecidas entre a biblioteca e o leitor e leva suas reflexões aos amigos modernistas, na tentativa de construir em instâncias políticas superiores um plano bibliotecário. Rubens Borba de Moraes problematizou a função, a ordem, a acessibilidade, o alcance cultural, social, temático e temporal dos acervos; trouxe para o debate das bibliotecas a insustentabilidade da visão do bibliotecário como guardador de livros.

Sua descrença no fazer bibliotecário começou quando percebeu que os cargos de bibliotecários eram ocupados por intelectuais que não entendiam o papel social que desempenhavam, tampouco demonstravam interesse em buscar novos meios de facilitar o acesso do público ao acervo, ambos em ascendente crescimento. Moraes reclamava que o modo de organização das bibliotecas não atendia aos anseios dos leitores acostumados com biblioteca. Sua reclamação nos faz observar que a organização de uma biblioteca aparece como um dispositivo integrador ou excludente de uma parcela da população até então não observada pelas bibliotecas.

A identificação dos problemas bibliotecários dos anos 1920 evidenciaria a necessidade de um momento conciliador entre a memória e o futuro e faria emergir o "plano bibliotecário" como um dos pilares paulista do movimento cultural modernista que visava ao mesmo tempo o rompimento com um gosto cultural e uma visão passadista do que era o Brasil, seguidos da construção de uma nova relação com as diversas culturas pujantes no país e a afirmação de uma identidade nacional que levasse em conta essa diversidade.

\footnotetext{
${ }^{157}$ Assumimos essa data simbólica para utilizar como marco da importação de um novo parque gráfico para a editora/gráfica Monteiro Lobato \& Cia., mesmo cientes de seu fracasso comercial nos anos subsequentes. Esse fracasso precisa ser relativizado na medida em que os projetos gráficos, o incremento no número de títulos e na tiragem impressa são heranças de Monteiro Lobato assumidas por outros agentes do campo editorial, dentre os quais José Olympio.
} 
Nos anos 1930, diversos grupos se mobilizaram por caminhos distintos para chegar à ruptura da fratura entre educação e biblioteca. Do ponto de vista dos educadores, diversos nomes ligados ao Manifesto dos Pioneiros defenderam em seus escritos a importância da Biblioteca Escolar como espaço educativo, de garantia de acesso aos que não pudessem ter acesso aos livros exigidos pelo currículo escolar. Além disso, tanto no âmbito estadual - com a regulação de divisão de tarefas entre Prefeitura e Estado no concernente ao financiamento das bibliotecas - quanto no âmbito federal, com a criação do Instituto Nacional do Livro, surgem os primórdios de afirmação de uma política pública para o setor.

A esses interlocutores, o projeto modernista encabeçado por Mário de Andrade, acompanhado por Rubens Borba de Moraes (no que tangia às bibliotecas), respondeu fornecendo infraestrutura para a atuação de uma importante liderança na área das bibliotecas escolares em São Paulo: Lenira Fraccaroli. Entretanto, o cerne do projeto era de uma biblioteca modernista com outra finalidade, nem oposta e nem complementar: o da leitura desinteressada, por um lazer que vai muito além do entretenimento.

No caso ideal de Rubens Moraes, é impossível pensar neste ideal sem invocar as condicionantes de seu desenvolvimento infantojuvenil. RBM encontrou no colégio genebrino de cultura franco-alemã o exemplo por excelência da Bildung, do percurso formativo livremente guiado pelas aptidões individuais. Por razões sociais e psicológicas, identificou-se com a realização desse percurso como meio de afirmar sua subjetividade, seu modo próprio de estar no mundo.

Ainda que a São Paulo dos anos 1930, em sua diversidade de situações sociais, fosse muito distinta da Genebra dos anos 1920 de Rubens Borba de Moraes, parece-lhe aceitável acreditar que tanto um pesquisador ao frequentar a Biblioteca Central, quanto um operário ao procurar a unidade da Mooca ou mesmo uma criança ao visitar sua biblioteca infantil estivessem a reproduzir, mutatis mutandis, a mesma experiência antropológica que ele próprio havia vivenciado e que lhe fora tão central.

O processo de constituição da Biblioteconomia se acentuou com o curso da Divisão de Bibliotecas do Departamento de Cultura que atribui à Biblioteconomia o lugar de pedra angular na formação de um Brasil moderno. Nesse sentido, essa disciplina é entendida como instrumento organizador do crescimento do país do ponto de vista desenvolvimentista que pairava sobre as políticas nacionais empregadas por Getúlio Vargas. A posição que a Biblioteconomia tem no projeto do Departamento demonstra sua centralidade e relevância na construção do "homem moderno", vale dizer, letrado. A modernização do Brasil passa por essa disciplina sob dois sentidos: o primeiro deles atrelado a conferir capilaridade às bibliotecas 
públicas alavancadas por projetos político-culturais locais e o segundo, à criação de redes de bibliotecas que se sustentam mutuamente. Tanto um quanto o outro simulam que o engajamento político- cultural é essencial na concretização da Biblioteconomia como campo de práticas e saberes.

Pensar em uma Biblioteconomia nestes moldes era tarefa hercúlea, que não se poderia vencer sem o auxílio de um valoroso batalhão. Ao menos assim pensou Rubens Borba de Moraes, pois ele não perdeu tempo ao assumir o cargo de Diretor de Bibliotecas do Departamento de Cultura. Já nos meses seguintes criou uma Escola, inicialmente sem financiamento próprio (1936), para no ano seguinte fortalecer sua institucionalização através de um pedido de verba que fosse própria.

Uma das apostas de Moraes foi a de que a sustentação e capilarização do "plano bibliotecário" dependia da formação dos profissionais. Com isso, sistematizou um curso que foi oferecido no primeiro momento na Escola de Biblioteconomia da Divisão de Bibliotecas e depois como um curso anexo à Escola de Sociologia e Política. Como alternativa ao bibliotecário tradicional, os cursos de Moraes resgatavam na história dos livros bibliotecários cuja importância de cada bibliotecário estava na inserção em seu tempo e contexto. Nesse sentido, reclama que se espera do profissional que ele tenha cultura geral, o que no entendimento de Moraes, refere-se à sua capacidade de acumular, recuperar e se apropriar do conhecimento histórico da própria cultura.

O "plano" consistia em impulsionar a formação de um corpo de profissionais com "mente bibliotecária" moderna, que conhecesse a influência das bibliotecas na história das sociedades e fossem conscientes de seu papel na construção de um futuro mais democrático para a nação brasileira. Esta preocupação ficou evidente nas tentativas de manutenção e continuidade da Escola de Biblioteconomia. Para Moraes, o problema das bibliotecas no Brasil não estava no fato de que não tínhamos biblioteca pública, mas sim no fato de que não tínhamos bibliotecas e nem bibliotecários com o sentido abrangente de públicos (BERTRAND, 2010) coisa de todos, em que a voz e a expressão não são cerceadas em nome de um preconceito ou de uma cultura erudita, superior.

O projeto que se mostrava local ganha projeções nacionais ao exigir que os alunos do curso se envolvessem com a modernização das bibliotecas públicas de sua cidade de origem e multiplicassem a formação recebida a outros interessados em atuarem como bibliotecários. Esse modo de ramificar o trabalho feito pela Divisão de Bibliotecas gera uma articulação local que se desdobra em um movimento bibliotecário nacional que circunscreve tanto o campo profissional quanto intelectual dos bibliotecários modernos. 
Ainda dentro do curso elaborado pela Divisão, fizeram-se ouvir outras concepções de biblioteca, com as quais Morais também demonstrou desacordo. Visões como a exposta na aula de Adelpha de Figueiredo, que consideravam as pessoas menos instruídas como tábulas rasas (BOSI, 2003), que por serem "atrasadas" precisavam ser "guiadas" por um "bibliotecáriomissionário" para lhes fornecer a "luz da ciência" (para repetir as palavras da própria Figueiredo).

A instrumentalização da leitura por bibliotecários levaria à confusão sobre o papel do bibliotecário e do professor, que apesar de serem análogos tinham sua singularidade no fato de que nas bibliotecas modernas, na concepção de Mário de Andrade e Rubens Borba de Moraes, não caberia a pedagogização da biblioteca. Moraes preferiu ver o bibliotecário como um “intelectual profissional militante" capaz de mobilizar uma das transformações que o mundo precisaria: a da democratização da leitura.

O próprio Rubens Borba de Moraes pode ser lido na chave deste novo bibliotecário emergente. Se por um lado já comentamos a respeito do desajuste entre as expectativas do jovem de 20 anos recém-chegado de Genebra e os valores culturais arraigados no cotidiano paulistano neste período, por outro lado é necessário relembrar certas propriedades sociais que permitiram a Rubens Borba de Moraes ocupar o papel de mobilizador em torno da construção de uma nova Biblioteconomia, e de como ele obteve resposta para suas demandas e anseios.

Rubens Borba de Moraes é uma figura importante para esse momento, pois, além de impulsionar as discussões e desenvolvimento do campo, teve a percepção de que a concepção de biblioteca, até então vigente, demandava uma ruptura. $\mathrm{O}$ momento era conflituoso. $\mathrm{O}$ fato de Rubens Borba de Moraes ter origem em família tradicional no Estado de São Paulo, pertencer a uma elite intelectual, ao lado de Mário de Andrade, compor a equipe que gerenciava os projetos do Departamento de Cultura e ser um entendedor de livros sobre o Brasil colonial, fez com que seu lugar de fala (RIBEIRO, 2019) lhe outorgasse o direito à crítica e também autoridade para alterar a forma como se discutia a biblioteca e os livros. Ele, como bibliófilo, compreendia a importância de saber preservar a memória cultural e, ao mesmo tempo, a necessidade de atualizar e organizar o modo como os processos vinham acontecendo.

Logo, o período de 1935 a 1945 tornou-se um momento transitório para as bibliotecas e para a biblioteconomia, porque além do período demandar ações, atores sociais como Rubens Borba de Moraes fizeram a leitura e organizaram a transição. Tal junção resultou em um momento marcado ao mesmo tempo por uma ruptura com uma compreensão de biblioteca como espaço de conservação e, ao mesmo tempo, uma abertura para a modernização de seu papel e modo de organização. É importante salientar que não se trata de uma substituição de 
paradigmas, mas de um processo transitório no qual é notável a distinção entre a permanência e a mudança.

A modernização está relacionada à técnica, mas a concepção da biblioteca, a essência do que é uma biblioteca se manteve no projeto. Há de se considerar que Mário de Andrade também foi importante naquele momento, embora ele não estivesse diretamente envolvido com o processo de constituição da biblioteconomia no período em que estava à frente do Departamento de Cultura. Ele participou ativamente do projeto de biblioteca proposto para a cidade de São Paulo.

A política de difusão cultural implementada por meio da Divisão de Bibliotecas compunha o plano de "reverter os efeitos desagregadores da modernização capitalista" (MONTEIRO, 2002) que dada sua lógica arquetípica desenraizam os sujeitos de sua própria cultura de modo a reificá-los e submetê-los às demandas do ritmo produtivo de uma sociedade em processo de industrialização (BOSI, 2003). A lógica moderna capitalista massificava os sujeitos como máquinas de uma engrenagem desprovidas, portanto, de memória e de participação real na construção do futuro da Nação que antevê uma relação irreconciliável entre passado e porvir. Para Rubens Borba de Moraes, tal lógica contradiz a estratégia de produção de novas representações de Nação do Brasil que se articula diante de si mesmo e de sua projeção no mundo. Ao esvaziar-se dos sentidos do passado no presente - contrapondo-se às teorias evolucionistas - sobrepõe-se o futuro estéril aos valores construídos coletivamente como sociedade.

Nesse sentido, o "plano bibliotecário" propõe um "sistema de bibliotecas" que visava promover a democratização cultural de forma a possibilitar a todas as pessoas o acesso à memória (por meio da leitura desinteressada e do estudo) com vistas a limitar a indeterminação do futuro, imposta pela engrenagem da industrialização. A biblioteca pública deveria incluir as crianças em processo de alfabetização e os operários, que teriam acesso restrito a jornais e novelas, e assim quebrar o paradigma de que a biblioteca é uma instituição restrita a letrados e eruditos. Diferentemente da concepção de biblioteca proposta anteriormente à criação do Departamento de Cultura, Moraes e Mário de Andrade concordam que a biblioteca oferecida aos operários deveria se constituir como um espaço de lazer e formação cultural e não apenas de preparação para o trabalho. Os leitores eram convidados a se expressarem por meio de cartas (Seção de Correspondência), expressões artísticas (Jornal Mural) e outras formas que se achassem possíveis para que a formação constituísse uma via de mão dupla. Havia em Moraes uma preocupação em mudar o modo como a biblioteca se colocava na sociedade, passando de seu papel até o modo como ela se organiza. A biblioteca no período que estudamos é o 
instrumento que os agentes na lida pela fermentação de uma cultura democrática dispõem para, dentro dos limites das estruturas políticas e econômicas de uma "República que nunca foi" (na feliz expressão de José Murilo de Carvalho), construir um país “moderno", no sentido de uma sociedade em que todos os cidadãos têm direito à participação, formação para isso e sem que alguma instituição ou desigualdade funcione como barreira para essa participação.

O projeto modernista e modernizante de Biblioteconomia não conseguiu se realizar por completo, e aqui está outro feixe de paradoxos, com os quais se projeta luz para a condição atual da Biblioteconomia. A ação social promovida pelo núcleo de RBM e Mário de Andrade não ocorreu em terra incógnita, mas em uma sociedade onde os mecanismos de reprodução de desigualdade atuaram na conformação das relações sociais havia então quatro séculos, período no qual poucos traços de continuidades foram tão fortes quanto a sua lógica: preservar e justificar a hegemonia das classes dominantes. Tais marcas provocaram desajustes entre o modernismo proposto por Moraes e seus colegas e a modernização necessária numa sociedade que historicamente se pautou pela restrição à escolarização e ao acesso aos livros pela população, ou seja, que organizou pela negação à modernização social, elemento fundante de uma sociedade moderna (CANCLINI, 2000). Tal desajuste se desdobra na divisão internacional do trabalho para preservar os mesmos grupos dominantes.

Os enfrentamentos entre o projeto de Mário de Andrade no Departamento de Cultura e a cultura política local já foram suficientemente demonstrados por outros estudos ${ }^{158}$. Cabe-nos aqui investigar como o projeto bibliotecário lida com esses abismos estruturantes, de modo a evitar uma visão maniqueísta que posicione RBM e seu grupo como simples vítimas, incapazes de oferecer uma resposta negociada com seus interlocutores. Pretende-se evitar o risco de teleologicamente, escolher como leitmotiv da história a derrota do projeto do Departamento de Cultura, como se ele estivesse fadado a esse destino tal qual em uma tragédia grega.

Alterar essa visão implica também ser sensível e perceber que a herança deixada por RBM, resultante dessa negociação, implica em aceitar elementos que reproduzem a desigualdade que se pretendia combater. Um exemplo prático ajuda a entender a questão: como visto no tema da seleção de estudantes para a Escola, era mister contar com uma mão de obra bastante habilitada para lidar com os desafios intrínsecos a essa nova visão de bibliotecária. Ocorre que tal formação inicial só era disponível aos membros muito restritos de uma elite econômica e cultural. Deste modo, sem prejuízo dos aspectos democráticos, socialmente

\footnotetext{
${ }^{158}$ BARBATO JUNIOR, R. L. de A. Missionários de uma utopia nacional-popular. São Paulo: Annablume, 2004. OLIVEIRA, F. Intelectuais, cultura e política. Plural - Revista do Programa de Pós-graduação em Sociologia da USP, v. 12, p. 12-19, 2005.
} 
inclusivos, e teóricos, dotados de uma concepção de cultura isenta de hierarquizações ${ }^{159}$, a exigência acabava em impasse de difícil resolução: de um lado, atendia a complexidade das demandas profissionais modernas, que exigiam técnica e domínio prévios de repertórios culturais letrados. Por outro, por tal razão, fechava a profissão a círculos restritos e privilegiados, insuficientes para atender os propósitos de universalização letrada pretendida pelo projeto.

Outra negociação com o status quo, também dotado de um caráter ambíguo em que se reproduzem certos aspectos sociais e ao mesmo tempo se busca mudar outros, tem relação com o financiamento da Fundação Rockfeller para a Escola de Biblioteconomia, nos anos 1940. Queremos defender que apresentar Rubens Borba de Moraes como vetor de uma intrusão imperialista em assuntos brasileiros é um anacronismo, do qual decorre um dos problemas mais recorrentes na literatura sobre a história da Biblioteconomia.

Primeiramente, é forçoso admitir que aos nossos olhos de brasileiros do século XXI está suficientemente comprovado o quanto o imperialismo (hard ou soft power) minou a luta de amplos setores da sociedade brasileira pela diminuição das desigualdades. Nós vivemos a intervenção de Lincoln Gordon no Brasil dos anos 1950 e 1960 e como isso resultou na ditadura civil-militar que resultou na morte e na tortura de muitos ativistas sociais. Também vivemos, mais recentemente, a operação Lava-Jato, com apoio logístico do serviço secreto estadunidense, do qual resultou a destruição da indústria de base nacional.

Ora, o Rubens Borba de Morais dos anos 1930 não tinha vivenciado nenhum desses eventos históricos. O que ele enxergava, em seu cotidiano de intelectual na administração pública, era uma dificuldade imensa em lidar com a reprodução de certos preconceitos como a de que os pobres não mereceriam ter biblioteca, ou de que todo trabalho feminino deveria ser algo menor, menos importante e/ou uma continuidade da "natureza materna" das mulheres (p. ex. enfermagem, assistência social, docência nos níveis básicos da educação).

Para alguém que vivenciou esse desafio em um período como o do Estado Novo estabelecido por chefes políticos, de tendências acirradamente autoritárias, contrários ao grupo político que sustentou o projeto modernista em São Paulo - a oferta de um grupo poderoso, preocupado com a diminuição da pobreza ${ }^{160}$, pode ter soado como a última tábua de salvação e

\footnotetext{
${ }^{159}$ Para a discussão na Antropologia dos anos 1930 sobre a cultura em uma perspectiva adotada pelos modernistas, conferir os trabalhos de Monteiro (s.d), Clifford (2011), Ribeiro (2005), Franz Boas (2004), Geiger (1999) e Moraes (1983).

${ }^{160}$ Como já demonstrado no capítulo 4 , Rockfeller considerava que um elevado grau de pobreza nos países explorados por seu grupo petrolífero poderia gerar instabilidade em seus negócios. Trata-se, evidentemente, de um cálculo de risco que não tem nada a ver com altruísmo.
} 
a possibilidade de reconhecimento de seu projeto. Novamente, RBM pensava não apenas como paulista, mas como "cidadão do mundo", que poderia não apenas reforçar a experiência em São Paulo, mas ganhar redes de sociabilidades que poderiam amplificar sua visão de Biblioteconomia em outras partes do globo.

Essa leitura pode ser confirmada com a participação de Rubens Borba de Moraes nos Congressos da ALA, tanto em 1939 quanto em 1947. Em ambos os casos, ele traz contribuições autorais, elementos que poderiam ser copiados para outros países - longe de ser, portanto, um comportamento "colonizado", de um cúmplice do imperialismo.

Resta ainda por compreender a breve passagem de RBM pelo Rio de Janeiro, cheio de desencontros e mal-entendidos. Em geral, sua decisão de aplicar a classificação decimal de Dewey foi compreendida pela bibliografia como a prova cabal de falta de habilidade bibliotecária, ou até de entreguismo. Pensamos que este evento também adquire novas luzes quando lido à luz daquela realidade histórica.

No capítulo 4, descreveu-se como RBM não conseguiu se inserir na trama bibliotecária já existente no Rio de Janeiro, mais, talvez, por fazer resistência aos modus vivendi ali instalados que por sua incapacidade de fazer a leitura das singularidades a separar a capital federal de São Paulo. Nesta última, não havia um corpo constituído de funcionários, nem a instituição era vista como guardiã da memória nacional. Quando RBM é convidado para atuar na BN, estava passando da esfera municipal à federal, mudança que não significava apenas expansão e deslocamento geográficos, mas ingresso em disputas realizadas em território com lógicas distintas da Divisão de Bibliotecas do Departamento de Cultura.

Ato contínuo, busca auxílio para implementar algo semelhante ao que realizou em São Paulo, isto é, transformar a BN: de uma biblioteca pautada pela conservação do patrimônio para um centro de referência a serviço da população. Sua agilidade em perceber a falta de apoio pode ter conduzido para uma leitura de que o apoio internacional serviria como um contraponto eficiente. Gustavo Capanema, político mais experiente, corrigiu sub-repticiamente o erro ao engavetar o relatório feito pelos consultores estadunidenses trazidos com verba da Fundação Rockfeller.

Infelizmente, para RBM, o sucessor de Capanema não teve a mesma expertise. Deu-se a partir de então uma sucessão de gestos de inabilidade política que custaram a RBM não apenas o cargo, mas um certo amargor com o campo bibliotecário nacional correspondido reciprocamente por muitos atores do mesmo campo, especialmente os que não conhecem o cenário paulista da atuação de RBM. 
O que hoje nos faz voltar ao período é o fato de que assim como naquele momento, hoje notamos que há uma intensificação nas discussões sobre o papel social e educacional das bibliotecas, o que recai diretamente sobre qual tipo de Biblioteconomia que estamos construindo e quais os seus rumos. Em certa medida, responder para esta pergunta implica em levantar avanços e limites da Biblioteconomia modernista no Brasil, ou, indo um pouco mais além, nos questionarmos sobre os resultados e consequências dos planos bibliotecários que podem ser afrontados com aqueles que vivemos no âmbito das bibliotecas contemporâneas.

A partir de textos levantados nos acervos que consultamos, é possível identificar um movimento biblioteconômico mundial que acontecia nos anos de 1930. Podemos observar que Moraes entrou na "onda" de modernização das bibliotecas ao mesmo tempo em que atuava no desenvolvimento de uma Biblioteconomia nacional.

RBM viu a biblioteca como uma obra de arte para a qual o bibliotecário trabalha em função de algum compromisso histórico que lhe toca. No seu caso foi a necessidade de compreender as próprias raízes que gerou o anseio por desarrolhar um projeto de biblioteca histórica sobre o Brasil. Para Moraes, o paradigma da "biblioteca templum" cuja intencionalidade era a de "salvar almas" não mais condiria com a dimensão social que a biblioteca tomou com os projetos político-culturais de livro, leitura e biblioteca. Na verdade, para ele teria maior importância questionar quem era o profissional em ação. Qual seu grau de conhecimento geral e técnico? Qual sua relação com os livros? Qual o seu interesse em se especializar e conhecer muito bem seu universo de trabalho? A resposta formulada por RBM para estas perguntas nos leva a concluir que ele se dedicou a minar a lógica da rivalidade dualista entre técnica e humanismo sem deixar de vislumbrar um projeto nacional de Bibliotecas no qual a organização do acervo seguisse uma lógica global.

Ao realizar este percurso intelectual, RBM pode ser visto como um exemplo de uma série de projetos intelectuais de intervenção no país durante os anos 1930 e 1940 que podem ser descritos da forma abaixo:

O resultado foi uma convergência de práticas e ações que se inseriram em um movimento pendular de criação/renovação, bem como nacionalização/universalização da cultura brasileira, que se servia de diferentes mídias, não se restringindo à indústria editorial, embora tenham estabelecido com ela um fértil diálogo, que vai resultar em ricas interações nos anos subsequentes. (DUTRA, 2010, p. 237)

Muitos dos discursos relacionados à modernização da biblioteca a compreendiam simplesmente como adoção de um novo modo de organização documentária. Por exemplo, 
referiam-se à adoção do sistema de Classificação Dewey, em uso em bibliotecas americanas e europeias. Rubens Borba de Moraes, ao contrário, não via a biblioteca como uma instituição isolada de organização e preservação documental, mas como um projeto de cultura e educação de grande abrangência.

Nesse sentido, o que RBM apresentou junto com os modernistas no projeto do Departamento de Cultura e Recreação da Prefeitura de São Paulo (1935), o discurso realizado na Casa do Estudante (1943) são ideias que de certa forma se repetem nos relatórios da Biblioteca Nacional (1947); todos eles mostram que, para Moraes, a modernização da Biblioteca, diferentemente do que defendiam alguns outros bibliotecários como, por exemplo, Sylvia de Queiróz Sambaquy ${ }^{161}$, não se reduzia à modernização de técnicas de classificação e sim abarcavam o modo de pensar a biblioteca na sociedade brasileira que buscava os caminhos para sua modernização.

Moraes reconhecia a quantidade e a qualidade de bibliotecas existentes, pois entendia que não se tratava de colocá-las abaixo e criar novas bibliotecas no lugar. Por outro lado, defendia a necessidade de discutir os sentidos das bibliotecas na sociedade e a partir daí mudar as estruturas do que estava construído. Quando RBM fala que o plano de biblioteca não pode ficar à mercê das gestões governamentais e diz que aí estão os cursos de biblioteconomia, lança para o Estado o compromisso de participar da reflexão sobre o papel constitutivo da biblioteca na cultura nacional. Seu apelo é para que estas instituições tomem forma de política pública permanente.

Em suma, o que pretendemos fazer ao longo da presente tese foi demonstrar que quando compreendemos as condições de surgimento do campo da Biblioteconomia, compreendemos melhor os embates e impasses do presente ligados à identidade profissional do bibliotecário, seu papel social, educativo e cultural. Além disso, demonstramos que a compreensão sobre o lugar e papel da biblioteca na sociedade complexa na qual estamos inseridos enfrenta o desafio da falta de seu reconhecimento como instância emancipadora, capaz de cortar círculos viciosos que levam à reprodução das desigualdades sociais, seja através da negação do acesso às manifestações culturais e artísticas de nossa sociedade e do conjunto de experiências históricas disponíveis para o conhecimento, seja através da afirmação de culturas superiores às outras e, portanto, da justificativa para hierarquizações sociais com base nas manifestações culturais em seu sentido mais amplo. Território em disputa, a Biblioteconomia não poderia se constituir à

\footnotetext{
${ }^{161}$ Sylvia de Queiroz era irmã de Lydia de Queiroz Sambaqui, que foi bibliotecária formada pela Biblioteca Nacional, em 1938, e pela Columbia University, em 1942, e teve um importante papel na biblioteca do DASP e em aspectos relacionados à catalogação nos anos 1940 .
} 
parte dos conflitos históricos e sociais que marcam sua emergência no país, fruto de um movimento amplo que a extrapola, mas que permitiu sua afirmação como campo profissional autônomo e reconhecido oficialmente, por meio da Lei 4084, de 30 de junho de 1962, que dispôs sobre a profissão de bibliotecário e regulou seu exercício. Evidentemente, as disputas no campo e com outros campos continuaram - e continuam - da mesma forma que colaborações e esforços conjuntos, dependendo de contingências e opções. Assim, a errância observada em sua constituição indica que continuam vivos os obstáculos ao direito à cultura letrada, no Brasil, onde privilégios históricos se mantêm, apesar de esforços de modernização que foram ocorrendo ao longo do tempo; concomitantemente, é possível observar mobilizações e buscas que, apesar dos obstáculos e a contrapelo conseguiram criar fato histórico novo e desconhecido do país: a Biblioteconomia, entendida como manifestação empenhada, campo políticocultural, voltado à afirmação do direito irrestrito de todos à cultura letrada. Os caminhos que caracterizam tal criação são sinuosos, repletos de idas e vindas, contraditórios. No entanto, não abalam a magnitude da criação, cujo cerne está em apontar para a centralidade da cultura na vida política e social, assim como a dos diferentes atores sociais que aí desempenham suas ações. Nosso século XXI recebeu, assim, uma herança que demanda cuidados especiais, dada a errância dos contextos onde ela se constituiu. 


\section{REFERÊNCIAS}

ABDANUR, E. F. Os "ilustrados" e a política cultural em São Paulo: o departamento de cultura na gestão Mario de Andrade (1935-1938). 1992. Dissertação (Mestrado em História) Instituto de Filosofia e Ciências Humanas, Universidade Estadual de Campinas, Campinas, 1992. Disponível em: http://www.repositorio.unicamp.br/handle/REPOSIP/278642. Acesso em: 18 jul. 2019.

ABREU, A. A. de. Congresso Brasileiro de Escritores, I. In: Dicionário HistóricoBiográfico Brasileiro - Verbete. CPDOC/FGV Centro de Pesquisa e Documentação de História Contemporânea do Brasil, 2009. Disponível em:

http://www.fgv.br/cpdoc/acervo/dicionarios/verbete-tematico/congresso-brasileiro-deescritores-i. Acesso em: 09 dez. 2020.

ALMEIDA JÚNIOR, O. F. de. Profissional da informação: entre o espírito e a produção. In: VALENTIM, Marta Lígia (Org.). Profissionais da informação: formação, perfil e atuação profissional. São Paulo: Polis, 2000, p.31- 51. (Palavra-Chave; 11).

ALMEIDA JÚNIOR, O. F. de. Sociedade e Biblioteconomia. São Paulo: Polis, APB, 1997.

ANDRADE, M. de. Departamento Municipal de Cultura. O Estado de São Paulo, ano 62, n. 20.335, p. 3, 21 fev. 1936. Disponível em: https://acervo.estadao.com.br/pagina/\#!/1936022120355-nac-0003-999-3-not. Acesso em: 04 abr. 2020.

ANDRADE, O. de. Manifesto da poesia Pau-Brasil. Jornal Correio da Manhã, ano 23, n. 9.147, Rio de Janeiro, p. 5, 18 mar. de 1924. Disponível em:

http://memoria.bn.br/docreader/DocReader.aspx?bib=089842_03\&pagfis=18756. Acesso em: 21 abr. 2021.

ANDRADE, M. de. Ofício de 07 de agosto de 1935. São Paulo: Departamento de Cultura e Recreação, 1935.

ANDRADE, O. de. O manifesto antropófago. In: TELES, G. M. Vanguarda europeia e modernismo brasileiro: apresentação e crítica dos principais manifestos vanguardistas. 3. ed. Petrópolis: Vozes; Brasília: INL, 1976. Disponível em:

https://www.ufrgs.br/cdrom/oandrade/oandrade.pdf. Acesso em: 27 mar. 2021.

ANTUNES, C. Rubens Borba de Moraes: anotações de um bibliófilo. São Paulo: Publicações BBM, 2017.

ARAÚJO, D.; REIS, A. S. dos. Bibliotecas, Bibliofilia e Bibliografia: alguns apontamentos. InCID: Revista de Ciência da Informação e Documentação, v. 7, p. 183-201, 2016. Disponível em: https://www.revistas.usp.br/incid/article/view/118770. Acesso em: 05 abr. 2020 .

ARENDT, H. A condição humana. Rio de Janeiro: Forense Universitária, 2007.

ASSIS, L. da S. de. Bibliotecas públicas e políticas culturais: a Divisão de Bibliotecas do Departamento de Cultura e Recreação da Prefeitura de São Paulo (1935). 2013. Dissertação (Mestrado em Ciência da Informação) - Escola de Comunicações e Artes, Universidade de 
São Paulo, São Paulo, 2013. Disponível em:

https://teses.usp.br/teses/disponiveis/27/27151/tde-28012014-121948/pt-br.php. Acesso em: 10 mar. 2021.

ASSOCIAÇÃO de Bibliothecarios. In: Correio Paulistano. São Paulo, ano 1936, ed. B24579, p. 13, Seção Associações, 05 maio 1936. Disponível em:

$\mathrm{http}: / /$ memoria.bn.br/docreader/DocReader.aspx?bib=090972_08\&pagfis=12255. Acesso em: 10 abr. 2021.

ASSOCIAÇÃO paulista de bibliothecarios. In: Correio Paulistano. São Paulo, ano 1938, ed. 25386, p. 3, 10 dez. 1938. Disponível em:

http://memoria.bn.br/DocReader/docreader.aspx?bib=090972_08\&pasta=ano\%20193\&pesq= 10\%20dezembro\%201938\&pagfis=27007. Acesso em: 10 abr. 2021.

ASSUNÇÃO, I. T. de. Historiografia linguística do movimento antropofágico: por uma literatura popular para a firmação da língua e da identidade brasileiras. 2010. Dissertação (Mestrado em Letras e Linguística) - Faculdade de Letras, Universidade Federal de Goiás, Goiânia, 2010. Disponível em:

https://files.cercomp.ufg.br/weby/up/26/o/Isac_Teixeira_de_Assun___o_-

_Disserta__o.pdf. Acesso em: 07 out. 2020.

AZEVEDO, F. de et al. Manifestos dos pioneiros da Educação Nova (1932) e dos

educadores 1959. Recife: Fundação Joaquim Nabuco, Editora Massangana, 2010. Disponível em: http://www.dominiopublico.gov.br/download/texto/me4707.pdf. Acesso em 10 abr. 2021.

BACHELARD, G. La formation de l'esprit scientifique. Paris. J. Vrin, 1938.

BANDEIRA, S. P. O mestre dos livros: Rubens Borba de Moraes. Brasília: Briquet de Lemos, 2007.

BARBATO JÚNIOR, R. Missionários de uma utopia nacional-popular: os intelectuais e o Departamento de Cultura de São Paulo. São Paulo: Annablume; FAPESP, 2004.

BAUDRILLARD, J. O sistema dos objetos. São Paulo: Perspectiva, 1993.

BAUER, M. W; GASKELL, G. Pesquisa qualitativa com texto, imagem e som: um manual prático. Petrópolis: Vozes, 2002.

BAUMAN, Z. Globalização: as consequências humanas. Rio de Janeiro: Zahar, 1999.

BECKER, H. Mundos da arte. Lisboa: Livros Horizonte, 2010.

BECKER, H. S.; PESSIN, A. A Dialogue on the Ideas of "World" and "Field". In:

Sociological forum, v. 21, n. 2. Springer, 2006.

BERTRAND, A. Bibliothèque publique et public library: essai de généalogie comparéi.

Villeurbane: Presses de l'enssib, 2010.

BOAS, F. Antropologia cultural. Rio de Janeiro: Zahar, 2004.

BOSI, A. Dialética da colonização. São Paulo: Companhia das Letras, 1992. 
BOSI, A. Reflexões sobre a arte. São Paulo: Ática, 2003.

BOSI, A. Tempo Vivo da Memória. São Paulo: Ateliê Editorial, 2003.

BOURDIEU, P. Campo del poder y campo intelectual. Buenos Aires: Folios, 1983.

BOURDIEU, P.; WACQUANT, L. Réponses: pour une anthropologie reflexive. Paris: Seuil, 1992.

BRASIL. Decreto-lei n 24 , de 29 de novembro de 1937. Dispõe sobre a acumulação de funções e cargos públicos remunerados, e dá outras providências. Diário Oficial da União: seção 1, Brasília, DF, p. 23672, 01 jan. 1937. Disponível em:

https://www2.camara.leg.br/legin/fed/declei/1930-1939/decreto-lei-24-29-novembro-1937351813-publicacaooriginal-1-pe.html. Acesso em: 07 abr. 2021.

BRÜSEKE, F. J. A modernidade técnica. RBCS - Revista Brasileira de Ciências Sociais, v. 17, n. 49, p. 136-173, 2002. Disponível em:

http://www.scielo.br/j/rbcsoc/a/GptC7gQGJkcvt4qhwKKNHtQ/?format=pdf\&lang=pt.

Acesso em: 20 abr. 2021.

BURKE, P. Cultura popular na idade moderna: Europa, 1500-1800. São Paulo:

Companhia das Letras, 2010.

BURKE, P. Uma história social do conhecimento: de Gutemberg a Diderot. Rio de Janeiro: Jorge Zahar, 2003.

BUTLEN, M. Les politiques de lecture et leurs acteurs, 1980-2000. Lyon: INRP, 2008.

CANCLINI, N. G. A globalização imaginada. São Paulo: Iluminuras, 2003.

CANCLINI, N. G. Industrias culturales y globalización: procesos de desarrollo e integración en América Latina. Estudios internacionales, p. 90-111, 2000.

CANDIDO, A. Formação da literatura brasileira: momentos decisivos. 3. ed. São Paulo: Martins, 1969.

CASTELlO, J. A. A literatura brasileira: origens e unidade (1500-1960). São Paulo: Edusp, 1999.

CASTELLS, M. A sociedade em rede: do conhecimento à política. In: CASTELL, M; CARDOSO, G. A sociedade em rede: do conhecimento à acção política. Belém: Imprensa Nacional, 2005.

CASTRO, C. A. História da biblioteconomia brasileira. Brasília: Thesaurus Editora, 2000.

CASTRO, C. A.; RIBEIRO, M. S. P. As contradições da sociedade da informação e a formação do bibliotecário. Revista Digital de Biblioteconomia e Ciência da Informação, Campinas, v. 2, n. 1, p. 41-52, 2004. Disponível em:

https://periodicos.sbu.unicamp.br/ojs/index.php/rdbci/article/view/2079. Acesso em: 23 maio. 2021.

CATANI, A. M. et al. (org.). Vocabulário Bourdieu. Belo Horizonte: Autêntica, 2017. 
CERQUEIRA, V. L. C. de. Contribuições de Samule Lowrie e Dina Lévi-Strauss ao departamento de cultura de São Paulo (1935 - 1938). 2010. Dissertação (Mestrado em Ciências Sociais) - Pontifícia Universidade Católica de São Paulo, São Paulo, 2010.

CHARTIER, R. A ordem dos livros: leitores, autores e bibliotecas na Europa entre os séculos XIV e XVIII. Brasília: Editora Universidade de Brasília, 1994.

CHARTIER, R. A ordem dos livros: leitores, autores e bibliotecas na Europa entre os séculos XIV e XVIII. Brasília: Editora Universidade de Brasília, 1999.

CHATZIMANASSIS, A. Démocratisation de la culture et démocratie culturelle à partir de l'exemple québécois. In: BODT, R.; LOWIES, J.-G. Démocratie culturelle e

démocratisation de la culture. Bruxelas: Observatório des Politiques Culturelles; Federation Wallanie-Bruexelles, 2014a.

CHATZIMANASSIS, A. La démocratie culturelle : un autre modèle de politique culturelle. Politiques de la culture, p. 1 - 9, 2014b. Disponível em: http://chmcc.hypotheses.org/675. Acesso em: 03 abr. 2021.

CLARO, S. F. Revista do Arquivo Municipal de São Paulo: um espaço científico e cultural esquecido (proposta inicial e as mudanças na trajetória - 1934-1950). 2008. Tese (Doutorado em História Social) - Faculdade de Filosofia, Letras e Ciências Humanas, Universidade de São Paulo, São Paulo, 2008. Disponível em: https://teses.usp.br/teses/disponiveis/8/8138/tde09022009-164245/pt-br.php. Acesso em: 03 maio 2021.

CLIFFORD, J. A experiência etnográfica: antropologia e literatura no século XX. Rio de Janeiro: Ed. UFRJ, 2011.

COMMUM de dois. Correio Paulistano. São Paulo, 05 dez. 1935. Notas e Comentários, p. 5. Disponível em:

http://memoria.bn.br/docreader/DocReader.aspx?bib=090972_08\&pagfis=10216. Acesso em: 19 fev. 2021.

COMTE, A. Cours de philosophie positive, 1877. Disponível em:

https://bibdig.biblioteca.unesp.br/handle/10/28016. Acesso em: 03 mar. 2021.

COSTA, A. L. J. da. Associativismo operário, educação e autonomia na formação da classe trabalhadora em São Paulo (1889-1930). Educ. Pesqui., São Paulo, v. 44, 2018. Disponível em http://www.scielo.br/j/ep/a/GXMzcDwzmtSXjCdqryWM9rP/?format=pdf\&lang=pt. Acesso em: 03 maio 2021.

COSTA, F. M. Bibliofilia: a eterna devoção aos livros. 2009. Trabalho de conclusão de curso (Graduação em Biblioteconomia) - Curso de Biblioteconomia, Escola de Comunicação e Artes, Universidade de São Paulo, São Paulo, 2009.

DARNTON, R. O grande massacre de gatos. 2. ed. Rio de Janeiro: Graal, 1988.

DAVINSON, D. Bibliographic Control. London, Clive Bingley, 1975. 
DEAECTO, Marisa Midori. Duas Brasilianas. Livro: Revista do Núcleo de Estudos do Livro e da Edição, São Paulo: Ateliê Editorial/NELE, 2011, v. 1, p. 39-50.

DIAS, A. C. Na Biblioteca Nacional. Chronos: publicação cultural da UNIRIO, v. 1, n. 10. Rio de Janeiro: UNIRIO, 2015.

DOSSE, F. El arte de la biografía: entre historia y ficción. México: Universidad Iberoamericana, 2007.

DOSSE, F. O desafio biográfico: escrever uma vida. São Paulo: Edusp, 2009.

DUARTE, P. Mário de Andrade por ele mesmo. 2. ed. São Paulo: HUCITEC, 1985.

DUARTE, P. Mário de Andrade por ele mesmo. São Paulo: HUCITEC, 1977.

DUTRA, E. de F. Cultura. In: GOMES, A. de. C. Olhando para dentro (1930 - 1964).

Objetiva /Fundació Mapfre, 2010.

EL FAR, A. O livro e a leitura no Brasil. Rio de Janeiro: Jorge Zahar, 2006.

EL-DINE, L. R. Z. Ensaio e interpretação do Brasil no modernismo verde-amarelo (19261929). Estudos Históricos, Rio de Janeiro, v. 32, n. 67, p. 450 - 468, 2019. Disponível em: http://www.scielo.br/j/eh/a/Mg7tG9YJ9TFV3ytjYb9JcXv/?lang=pt\&format=pdf. Acesso em: 03 abr. 2021.

EL-DINE, L. R. Z. Eugenia e seleção imigratória: notas sobre o debate entre Alfredo Ellis Junior, Oliveira Vianna e Menotti Del Picchia, 1926. História, Ciências, Saúde Manguinhos, Rio de Janeiro, v. 23, p. 243-252, 2016. Disponível em: http://www.scielo.br/j/hcsm/a/5H7Jr9BPZ5JHB4qQXNSqkjM/?format=pdf\&lang=pt. Acesso em 05 abr. 2020.

ELIAS, N. O Processo Civilizador: uma história dos costumes. Rio de Janeiro: Jorge Zahar Editor, 1990. v. 1.

FAORO, R. Os donos do poder: formação do patronato político brasileiro. São Paulo: Globo, 2001.

FAY, L. ALA: Good Neighbors. Books Abroad, v. 17, n. 2, p. 118, 1943.

FERNANDES, F. A revolução burguesa no Brasil: ensaio de interpretação sociológica. Rio de Janeiro: Zahar, 1975.

FIGUEIREDO, A. S. R. Aula inaugural. Escola de Biblioteconomia, Curso de catalogação. São Paulo, 17 ago. 1936.

FIGUEIREDO, A. S. R. Desenvolvimento da biblioteconomia em São Paulo: conferência realizada no DASP. Rio de Janeiro: DASP; Imprensa Nacional, 1945.

FONSECA, E. N. da. Introdução à Biblioteconomia. São Paulo: Pioneira, 1992.

FORMATURA dos bibliotecários do Departamento de Cultura e professorandas da Escola Normal "Padre Anchieta". Correio Paulistano, ano 1938, ed. 25395, São Paulo, p. 1, 21 dez. 
1938. Disponível em:

http://memoria.bn.br/DocReader/Hotpage/HotpageBN.aspx?bib=090972_08\&pagfis=27196\& url=http://memoria.bn.br/docreader\#. Acesso em 10 abr. 2021.

GEIGER, A. Uma antropologia sem métier: primitivismo e crítica cultural no modernismo brasileiro. 1999. Tese (Doutorado em Antropologia Social) - Museu Nacional, Universidade Federal do Rio de Janeiro, Rio de Janeiro, 1999.

GODOY FILHO, G. de. A mobilidade da população paulista através de seu crescimento. Revista do Arquivo Municipal, São Paulo, v. 16, n.2, ago. 1935.

GÓES, E. de. Ofício de 13 de agosto de 1935. São Paulo: Departamento de Cultura e Recreação, Divisão de Bibliotecas, 1935.

GOMES, A. C. A invenção do trabalhismo. Rio de Janeiro: FGV, 1988.

GOMES, A. M. de C. (org.) Escrita de si, escrita da história. Rio de Janeiro: FGV, 2004.

GOMES, D. P. O Departamento Municipal de Cultura de São Paulo (1935-1938):

políticas de criação de bibliotecas e democratização da leitura. 2008. Dissertação (Mestrado em Educação, História, Política e Sociedade) - Pontifícia Universidade Católica de São Paulo, São Paulo, 2008.

GRADY, C. Why public libraries are still essential in 2018: libraries exist for the public. Amazon exists to maximize profits. Vox, Washington, D.C., 24 jul. 2018. Disponível em: https://www.vox.com/culture/2018/7/24/17603692/public-libraries-essential-forbes-amazon. Acesso em: 13 out. 2020.

GROPP, A. E. Latin America, Committee on Library Cooperation with. In: ALA Bulletin, v. 33, n. 11, p. 135-136. 15 out. 1939.

GYMNASIO Macedo Soares. O Estado de S. Paulo, São Paulo, ano 43, n. 13989, p. 14, 24 jan. 1917. Disponível em:

HALLEWELL, L. O livro no Brasil. 2. ed. São Paulo, Edusp, 2005.

HELDER, R. R. Como fazer análise documental. Porto: Universidade de Algarve, 2006.

ILUSÃO biográfica. In: CATANI, A. M. et al (org.). Vocabulário Bourdieu. Belo Horizonte: Autêntica, 2017.

KOLLMAN, P. At the origins of mission and missiology: a study in the dynamics of religious language. Journal of the American Academy of Religion, Oxford: Oxford University Press, vol. 79, n. 2, p. 425-458, 2011. Disponível em: https://www.jstor.org/stable/23020433?seq=1. Acesso em: 03 abr. 2021.

KOPYTOFF, I. The cultural biography of things: commoditization as process. In:

APPADURAI, A. The social life of things: commodities in cultural perspective. Cambridge: Cambridge University Press, 2003.

LE DEUFF, O. La culture de l'information et l'héritage documentaire. DocumentalisteSciences de l'Information, 2010, n. 3, v. 47, p. 4-11. Disponível em: 
https://www.cairn.info/revue-documentaliste-sciences-de-1-information-2010-3-page-4.htm. Acesso em 10 abr. 2020.

LE GOFF, J. Documento/Monumento. Campinas: Unicamp, 1990.

LEJEUNE, P. O pacto autobiográfico: de Rousseau à internet. Belo Horizonte: UFMG, 2008.

LEMOS, A. A. B. de. Apresentação. In: MORAES, R. B. de. O problema das bibliotecas brasileiras. 2. ed. Brasília: ABDF, 1983.

LEMOS, A. A. B. de. Aproximações sobre a regulamentação da profissão de bibliotecário. Rio de Janeiro: Agência Biblioo, 2016.

LEMOS, A. A. B. de. De bibliotecas e biblioteconomias: percursos. Brasília, DF: Briquet de Lemos Livros, 2015.

LEMOS, A. A. B. de. Em busca dos temas perdidos. InCID: Revista de Ciência da Informação e Documentação, Ribeirão Preto, v. 5, n. 2, p. 34-50, set. 2014. Disponível em: https://www.revistas.usp.br/incid/article/view/84809. Acesso em: 10 abr. 2020.

LEWIS Hanke. In: INFOGALATIC: planetary knowledge core. [San Francisco, CA: Wikimedia Foundation, 2015]. Disponível em: https://infogalactic.com/info/Lewis_Hanke. Acesso em: 10 abr. 2021.

LIMA, M. H. T. de F. Marcas discursivas na formação de profissionais de memória. Informação \& Sociedade: estudos, João Pessoa, v. 14, n. 2, p. 87-108, 2004. Disponível em: https://brapci.inf.br/_repositorio/2010/11/pdf_c781a1cb37_0013102.pdf. Acesso em: 10 abr. 2021.

LIMA, R. M. de. A construção social da biblioteconomia brasileira: a dimensão políticopedagógica do fazer bibliotecário. Manaus: Editora da Universidade do Amazonas, 1999.

MACEDO, N. D. de; FUJITA, M. S. L. Vida e obra de Maria Luisa Monteiro da Cunha. Revista Brasileira de Biblioteconomia e Documentação, São Paulo, v. 25, n. 1/2, p. 131 145, jan. / jun. 1992. Disponível em:

https://brapci.inf.br/_repositorio/2011/10/pdf_ee8f22e7cb_0019210.pdf. Acesso em: 10 out. 2020 .

MAIA, J. de A. [Correspondência]. Destinatário: Gustavo Capanema (Ministro). São Paulo, 20 ago. 1937.

MAIA, J. de A. Índice - catalogo médico brasileiro. In: Correio Paulistano. São Paulo, ano 1939, ed. 25.672, p. 23, 12 nov. 1939. Disponível em:

http://memoria.bn.br/docreader/DocReader.aspx?bib=090972_08\&pagfis=31643. Acesso em: 10 abr. 2021.

MARTINS FILHO, P. (org.). Cartas de Rubens de Moraes ao livreiro português António Tavares de Carvalho. São Paulo: Biblioteca Brasiliana Guita e José Mindlin, 2018.

MARTINS, W. A palavra escrita: história do livro, da imprensa e da biblioteca. São Paulo: Ática, 1996. 
MATOS, L. de. A arte e o ensino. Revista Folha da Serra, n. 18, mar. 1933.

MEIRELES, C. Problemas da literatura infantil. São Paulo: Summus; Brasília: INL, 1984.

MELOT, M. A sabedoria do bibliotecário. Cotia, SP: Ateliê Editorial; São Paulo: Edições SESC SP, 2019.

MICELI, S. Vanguardas em retrocesso. São Paulo: Companhia das Letras, 2012.

MINDLIN, J. Rubens Borba de Moraes: um intelectual incomum. CIBEC - Revista Brasileira de Estudos Pedagógicos. Brasília, v. 79, n. 192, p. 109, maio/ago. 1998a.

MINDLIN, J. Uma vida entre livros: reencontros com o tempo. São Paulo: Edusp, Companhia das Letras, 1998b.

MONTEIRO, L. O movimento modernista e a construção de uma identidade nacional sob a égide do Estado Novo. In: Bibliobelas: o blog da Biblioteca "Professor Marcello de Vasconcellos Coelho" da Escola de Belas Artes da UFMG, fev. 2002. Disponível em: https://bibliobelas.files.wordpress.com/2012/02/1345085694_arquivo_artigolucianomonteirosbhc.pdf. Acesso em: 02 set. 2020.

MORAES, E. J. de. A brasilidade modernista: sua dimensão filosófica. Rio de Janeiro: Graal, 1978.

MORAES, E. J. de. A constituição da ideia de modernidade no Modernismo brasileiro. 1983. Tese (Doutorado em Filosofia). Instituto de Filosofia e Ciências Sociais - Universidade Federal do Rio de Janeiro, 1983.

MORAES, R. B. de. [Correspondência]. Destinatário: Gustavo Capanema. São Paulo, 1945.

MORAES, R. B. de. [Correspondência]. Destinatário: Mário de Andrade. São Paulo, 1922.

MORAES, R. B. de. A lição das bibliotecas americanas. Revista do Arquivo Municipal. São Paulo, v. 3, n. 2, p. 197-208, 1942.

MORAES, R. B. de. Aspectos históricos da biblioteca Mário de Andrade e o papel do Dr. Rubens na Biblioteconomia brasileira. [Entrevista cedida a] May Brooking Negrão. Bragança Paulista, 1983.

MORAES, R. B. de. Cultural Relations with Latin America. ALA Bulletin, v. 41, n. 9, 15 set. 1947.

MORAES, R. B. de. Depoimento de Rubens Borba de Moraes. [Entrevista cedida a] Museu da Imagem e do Som de São Paulo em 18 de set. 1981.

MORAES, R. B. de. Depoimento sobre a Biblioteca Pública Municipal de São Paulo. [Entrevista cedida a] Antonio Agenor Briquet de Lemos. Bragança Paulista, 7 de set. de 1978.

MORAES, R. B. de. Discurso de inauguração da Escola de Biblioteconomia. São Paulo, 1936. 
MORAES, R. B. de. Entrevista de Rubens Borba de Moraes. [Entrevista cedida a] Professores da Escola de Comunicações e Artes. Bragança Paulista, 1986.

MORAES, R. B. de. Entrevista de Rubens Borba de Moraes. [Entrevista cedida a] Marco Aurélio da Filgueira Gomes. 15 de set. 1982.

MORAES, R. B. de. História do livro. Notas de aula. Transcrição da disciplina Arte e Industria do Livro, Escola de Biblioteconomia, transcrito por J. Eduardo Oliveira de Barros, 22 abr. 1937.

MORAES, R. B. de. Lar Brasileiro. Revista de Antropofagia, São Paulo, ano 1, n. 9, p. 3, jan. 1929. Disponível em:

https://digital.bbm.usp.br/bitstream/bbm/7064/10/Anno.1_n.09_45000033273.pdf. Acesso em: 03 mar. 2020.

MORAES, R. B. de. Lembrança de Mário de Andrade: sete cartas. São Paulo: Kosmos, 1979a.

MORAES, R. B. de. Livros e bibliotecas no Brasil colonial. São Paulo: Secretaria da Cultura Ciência e Tecnologia do Estado de São Paulo, 1979b.

MORAES, R. B. de. O bibliófilo aprendiz: prosa de um velho colecionador para ser lida por quem gosta de livros, mas pode também servir de pequeno guia aos que desejam formar uma coleção de obras raras, antigas ou modernas. 2. ed. São Paulo: Editora Nacional, 1975.

MORAES, R. B. de. O bibliófilo aprendiz: prosa de um velho colecionador para ser lida por quem gosta de livros, mas pode também servir de pequeno guia aos que desejam formar uma coleção de obras raras, antigas ou modernas. 3. ed. Brasília: Briquet de Lemos, 2005.

MORAES, R. B. de. O engenheiro, o bibliotecário e o sentido de um projeto cultural. [Entrevista concedida a Sebastião de Souza]. 1985.

MORAES, R. B. de. O problema das bibliotecas brasileiras. Brasília: ABDF, 1983.

MORAES, R. B. de. O problema das bibliotecas brasileiras. Rio de Janeiro: Casa do Estudante do Brasil, 1943.

MORAES, R. B. de. Rascunho Conselho Bibliotecário do Estado, [1937b]. Pasta referente a Rubens Borba de Moraes, no fundo do Departamento de Cultura do Instituto de Estudos Brasileiros.

MORAES, R. B. de. Relatório do diretor da Biblioteca Nacional ao ministro da Educação e Saúde, relativo ao exercício de 1946. 1946. In: Revista de Biblioteconomia, Brasília, ano 2 , n. 2, p. 203 - 231, jul./dez., 1974. Disponível em:

https://periodicos.unb.br/index.php/rbbsb/article/download/28645/24916/. Acesso em: 20 abr. 2021.

MORAES, R. B. de. Testemunha ocular: recordações. Brasília: Briquet de Lemos, 2011.

MORIN, E. O pensar complexo: Edgar Morin e a crise da modernidade. Rio de Janeiro: Garamond, 1999. 
NAGLE, J. Educação e sociedade na primeira república. São Paulo: Editora Pedagógica e Universitária, 1976.

NEGRÃO, M. B. A evolução do Departamento de Bibliotecas Públicas, 1907-1978. Revista de Biblioteconomia de Brasília, Brasília, v.7, n.2, p. 186 - 208, jul./dez. 1979. Disponível em: $<$ http://basessibi.c3sl.ufpr.br/brapci/index.php/article/view/ 0000002961/c05ec8a076f70adbb7035ab099c420e7. Acesso em: 06 set. 2020.

NEGRÃO, M. B. Biblioteca pública municipal de São Paulo: da criação à consolidação (1926-1951), breve esboço histórico. 1983. 1983. Dissertação (Mestrado em Ciências da Comunicação) - Escola de Comunicação e Artes, Universidade de São Paulo, São Paulo, 1983.

NORA, P. Entre a memória e a história: a problemática dos lugares. Projeto História: Revista do Programa de Estudos Pós-Graduados de História, v. 10, n. 1, 1993.

ODDONE, N. O IBBD e a informação científica: uma perspectiva histórica para a ciência da informação no Brasil. Ciência da Informação, Brasília, v. 35, n. 1, p. 45-56, jan./abr. 2006. Disponível em: http://revista.ibict.br/ciinf/article/view/1152. Acesso em: 09 set. 2020.

OLIVEIRA, E. B. de. O conceito de memória na ciência da informação no Brasil: uma análise da produção científica dos programas de pós-graduação. 2010. Tese (Doutorado em Ciência da Informação) - Faculdade de Ciência da Informação, Universidade de Brasília, Brasília, 2010. Disponível em: https://repositorio.unb.br/handle/10482/7466. Acesso em: 03 abr. 2020.

OLIVEIRA, F. Intelectuais, cultura e política. Plural - Revista do Programa de Pósgraduação em Sociologia da USP, v. 12, p. 12-19, 2005.

OLIVEIRA, M. M de. Como fazer pesquisa qualitativa. Petrópolis, Vozes, 2007.

OTLET, P. Tratado de documentação: o livro sobre o livro, teoria e prática. Brasília: Briquet de Lemos, 2018.

PERROTTI, E. Infoeducação: um passo além científico-profissional. Informação@ Profissões, v. 5, n. 2, p. 05-31, 2016. Disponível em:

http://www.uel.br/revistas/uel/index.php/infoprof/article/view/28314. Acesso em: 10 abr. 2021.

PERROTTI, E. Sobre informação e protagonismo cultural. In: GOMES, H. F.; NOVO, H. F. (org.). Informação e Protagonismo Social. Salvador: EDUFBA, 2017.

PERROTTI, E.; PIERUCCINI, I. Infoeducação: saberes e fazeres da contemporaneidade. In: LARA, M. L. G, FUJINO, A.; NORONHA, D. P. (org.). Informação e contemporaneidade: perspectivas. Recife: Néctar, 2008.

PIMENTA, J. S. Fora do outono nem as aspirações amadurecem: Cecília Meireles e a criação da Biblioteca Infantil do pavilhão Mourisco (1934-1937). 2001. Dissertação (Mestrado em Educação) - Faculdade de Letras, Pontifícia Universidade Católica do Rio de Janeiro, Rio de Janeiro, 2011. 
PIMENTA, J. S. Leitura, arte e educação: a biblioteca infantil do Pavilhão Mourisco (19341937). Rio de Janeiro: CRV, 2011.

PINTO, J. M. et al. Um olhar sobre os indicadores de analfabetismo no Brasil. Revista Brasileira de Estudos Pedagógicos, v. 81, n. 199, 2000. Disponível em: http://www.rbep.inep.gov.br/ojs3/index.php/rbep/article/view/1340. Acesso em: 03 mar. 2020 .

POIRIER, M. Leadership et bibliothéconomie: description d'un programme conçu pour les futurs leaders des bibliothèques du Canada. Documentation et bibliothèques, v. 47, n. 1, p. 33-38, 2001. Disponível em: https://www.erudit.org/fr/revues/documentation/2001-v47-n1documentation02031/1032649ar/. Acesso em: 10 abr. 2021.

QUINN, M. E. Historical dictionary of librarianship. Rowman \& Littlefield, 2014.

RAFFAINI, P. T. Esculpindo a cultura na forma Brasil: o departamento de cultura de São Paulo (1935-1938). São Paulo: Humaitas/FFLCH/USP, 2001.

RAMOS, P. de A. Partido Democrático de São Paulo (PD). In: Dicionário HistóricoBiográfico Brasileiro - Verbete. CPDOC/FGV Centro de Pesquisa e Documentação de História Contemporânea do Brasil, 2009. Disponível em:

http://www.fgv.br/cpdoc/acervo/dicionarios/verbete-tematico/partido-democratico-de-saopaulo-pd. Acesso em: 09 dez. 2020.

RANGEL, T. R. A construção da identidade do profissional da informação em Biblioteconomia partir do DASP, do IBBD e do IBICT: um estudo histórico a partir de fontes primárias das instituições no período 1930-1950. 2017. Dissertação (Mestrado em Ciência da Informação) - Escola de Comunicação, Instituto Brasileiro de Informação em Ciência e Tecnologia, Universidade Federal do Rio de Janeiro, Rio de Janeiro, 2017. Disponível em: https://ridi.ibict.br/handle/123456789/961. Acesso em: 21 abr. 2021.

REGULAMENTO do Departamento de Cultura. São Paulo: Prefeitura de São Paulo, 1935.

REIFSCHNEIDER, O. D. B. A bibliofilia no Brasil. 2011. Tese (Doutorado em Ciência da Informação) - Faculdade de Ciência da Informação, Universidade de Brasília, Brasília, 2011. Disponível em: https://repositorio.unb.br/handle/10482/10744. Acesso em: 05 abr. 2020.

REIPERT, H. J. História da Biblioteca Pública Municipal Mário de Andrade. São Paulo: Prefeitura do Município de São Paulo, Departamento de Cultura, Divisão de Bibliotecas, 1972.

RIBEIRO, D. Lugar de fala. São Paulo: Pólen Produção, 2019.

RIBEIRO, M. C. Arqueologia Modernista: viagens e reabilitação do primitivo em Mário e Oswald de Andrade. 2005. Dissertação (Mestrado em Antropologia Social) - Instituto de Filosofia e Ciências Humanas, Universidade Estadual de Campinas, Campinas, 2005. Disponível em: http://www.repositorio.unicamp.br/handle/REPOSIP/281514. Acesso em: 6 ago. 2019.

ROMAINVILLE, C. Démocratie culturelle \& démocratisation de la culture. Repères: Histoire des politiques culturelles, Bruxelles, n. 4-5, juin 2014. Disponível em: http://www.opc.cfwb.be/index.php?eID $=$ tx_nawsecuredl\&u $=0 \& g=0 \&$ hash $=\mathrm{c} 83 \mathrm{~d} 5 \mathrm{adfe} 788 \mathrm{ac} 0$ 
b70785f7ce1b25e023cd7259d\&file=fileadmin/sites/opc/upload/opc_super_editor/opc_editor/ documents/pdf/publications_OPC/Reperes_N4-5_BAT_BD.pdf. Acesso em: 09 dez. 2020.

RUSSO, L. G. M. A biblioteconomia brasileira: 1915-1965. Rio de Janeiro: INL, 1966.

SALIBA, E. T. As apostas na república. In: SCHWARCZ, L. M. (org.). A abertura para o mundo: 1889-1930. Rio de Janeiro: Objetiva/Fundacion Mapfre, 2010.

SAMBAQUY, L. de Q. O IBBD e a informação científica no Brasil. Ciência da Informação em Revista, Maceió, v. 7, n. 1, p. 10-18, maio 2020. Disponível em:

https://www.seer.ufal.br/index.php/cir/article/view/10193. Acesso em: 26 maio 2021.

SÃO PAULO (Cidade). Ato do Executivo Municipal de São Paulo n ${ }^{0} 1.146$, de 4 de julho de 1936. Consolida e modifica disposições referentes aos serviços, repartições e funcionários da Prefeitura, e dá outras providências. Diário Oficial da Cidade, 07 jul. 1936, p. 1. Disponível em: http://legislacao.prefeitura.sp.gov.br/leis/ato-gabinete-do-prefeito-1146-de-7-de-julho-de1936. Acesso em: 20 maio 2020.

SÃO PAULO (Cidade). Ato n. 1 de 1926. Sobre o regulamento da Bibliotheca Publica Municipal. Câmara Municipal de São Paulo, São Paulo, 12 de janeiro de 1926.

SÃO PAULO (Cidade). Processo n. 68.268 de 1938. Solicitando continuação do pagamento da verba mensal a escola de Biblioteconomia a partir de junho p.p., remetendo cópia da lei estadual e do regulamento em vigor. São Paulo, 1938a.

SÃO PAULO (Cidade). Secretaria da Educação. Actos Officiaes. In: Correio Paulistano. São Paulo, ano 1937, ed. 24951, p. 10, 16 jul. 1937b. Disponível em:

http://memoria.bn.br/DocReader/090972_08/19386. Acesso em: 10 abr. 2021.

SÃO PAULO (Cidade). Secretaria da Educação e Saúde Pública. In: Correio Paulistano. São Paulo, ano 1938, ed. 25102, p. 23, 09 jan. 1938b. Disponível em:

http://memoria.bn.br/docreader/DocReader.aspx?bib=090972_08\&pagfis=22251. Acesso em: 10 abr. 2021.

SÃO PAULO (Estado) Decreto n. 9.303, de 6 de julho de 1938. Consolida disposições sobre pagamento de gratificações para serviços extraordinários no ensino profissional e dá outras providências. Diário Oficial do Estado de São Paulo: Secretaria de Estado da Educação e Saúde Pública, 6 jul. 1938a. Disponível em:

https://www.al.sp.gov.br/repositorio/legislacao/decreto/1938/decreto-9303-06.07.1938.html. Acesso em: 07 abr. 2021.

SÃO PAULO (Estado). Decreto n. 9.494, de 14 de setembro de 1938. Aprova o Regulamento do Conselho Bibliotecário do Estado. Diário Oficial do Estado de São Paulo: São Paulo, Secretaria da Educação e Saúde Pública, São Paulo, 14 de setembro de 1938b. Disponível em: https://www.al.sp.gov.br/repositorio/legislacao/decreto/1938/decreto-9494-14.09.1938.html. Acesso em: 20 abr. 2021.

SÃO PAULO (Estado). Lei n. 2.839, de 05 de janeiro de 1937. Regulamenta os serviços de organização, administração e desenvolvimento de bibliotecas no Estado. Diário Oficial do Estado de São Paulo: São Paulo, Secretaria de Estado da Educação e Saúde, ano 47, n. 5, p. 3, 8 jan. 1937b. Disponível em: 
http://dobuscadireta.imprensaoficial.com.br/default.aspx?DataPublicacao=19370108\&Cadern $\mathrm{o}=$ Diario\%20Oficial\&NumeroPagina $=3$. Acesso em: 03 mar. 2020.

SAVIANI, D. História das ideias pedagógicas no Brasil. Campinas: Autores Associados, 2013.

SCHUTZ, A. Collected Papers I: the problem of social reality. The Hague: Martinus Nijhoff, 1962.

SCHWARCZ, L. M. Introdução. Sobre semelhanças e diferenças. In: SCHWARCZ, L. M. (org.). História da vida privada no Brasil. São Paulo: Companhia das Letras: 2000. v. 4.

SCHWARCZ, L. M. População e sociedade. In: SCHWARCZ, L. M. (org.). A abertura para o mundo: 1889-1930. Rio de Janeiro: Objetiva/Fundacion Mapfre, 2010. v. 3.

SERRES, A. Culture de 1'information à 1'université: savoir en jeux, enjeux de savoirs. In: LIQUETE, V. (coord.). Cultures de l'information. Paris: CNRS Editions, 2014.

SEVCENKO, N. O orfeu extático na metrópole: São Paulo sociedade e cultura nos frementes anos 20. São Paulo: Companhia das Letras, 2009.

SILVEIRA, F. J. N. da. O bibliotecário como agente histórico: do "humanista" ao "Moderno Profissional da Informação". Informação \& Sociedade: estudos, João Pessoa, v. 18, n. 3, p. 83 - 94, set./dez. 2008. Disponível em:

https://periodicos.ufpb.br/ojs/index.php/ies/article/view/1873. Acesso em: 23 abr. 2021.

SORÁ, G. Brasilianas: José Olympio e a gênese do mercado editorial brasileiro. São Paulo: Edusp, 2010.

SOUZA, F. das C. de. A construção escolar do bibliotecário brasileiro: ontem, hoje, amanhã. Ciência da informação, Brasília, v. 20, n. 2, p. 181-190, jul./dez. 1991. Disponível em: http://revista.ibict.br/ciinf/article/view/354/354. Acesso em: 14 maio 2021.

SOUZA, F. das C. de. Modernização e Biblioteconomia nova no Brasil. 1994. Tese (Doutorado em Educação) - Universidade Metodista de Piracicaba, Piracicaba, SP, 1994.

SOUZA, F. das C. de. Modernização e Biblioteconomia nova no Brasil. Florianópolis: NUP-CED-UFSC, 2003.

SOUZA, F. das C. de. O discurso sobre a educação em Biblioteconomia e Ciência da Informação caminhos teórico-metodológicos para a compreensão. In: CUNHA, M. V. da; SOUZA, F. das C. de. (Org.). Comunicação, gestão e profissão: abordagens para o estudo da ciência da Informação. Belo Horizonte: Autêntica, 2006, v. 1, p. 151-172.

SOUZA, F. das C. de. O ensino da Biblioteconomia no contexto brasileiro. Florianópolis: Editora da UFSC, 1990.

SOUZA, F. das C. de. O ensino da Biblioteconomia no contexto brasileiro: século XX. 2. ed. rev. Florianópolis: Editora da UFSC, 2009.

TASSO da Silveira. In: Enciclopédia Itaú Cultural de Arte e Cultura Brasileiras Verbete. São Paulo: Itaú Cultural, 2021. Disponível em: 
http://enciclopedia.itaucultural.org.br/pessoa22373/tasso-da-silveira. Acesso em: 24 mai. 2021.

TOTA, A. P. O imperialismo sedutor. São Paulo: Companhia das Letras, 2000.

UNESCO. Declaração universal da UNESCO sobre a diversidade cultural. UNESCO. Paris, França, 2002. Disponível em:

http://unesdoc.unesco.org/images/0012/001271/127160por.pdf. Acesso em: 28 maio 2019.

VALENTINI, L. Um laboratório de antropologia: o encontro entre Mário de Andrade, Dina Dreyfus e Claude Lévi-Strauss (1935-1938). 2010. Dissertação (Mestrado em Antropologia Social) - Faculdade Filosofia e Ciências Humanas, Universidade de São Paulo, São Paulo, 2010. Disponível em: https://www.teses.usp.br/teses/disponiveis/8/8134/tde-06062011132611/pt-br.php. Acesso em: 04 ago. 2020.

VAMPRÉ, S. O centenário da Fundação da Primeira Bibliotheca Pública de S. Paulo. O Estado de São Paulo, ano 51, n. 16.862, p. 2, 25 abr. 1925. Disponível em:

https://acervo.estadao.com.br/pagina/\#!/19250425-16862-nac-0001-999-1-not. Acesso em: 20 maio 2021.

VERGARA, J. I. O. Toda canção de liberdade vem do cárcere: homofobia, misoginia e racismo na recepção da obra de Mário de Andrade. Tese (Doutorado em Música) - Centro de Letras e Artes, Universidade Federal do Estado do Rio de Janeiro, Rio de Janeiro, 2018. Disponível em: http://www.repositorio-bc.unirio.br:8080/xmlui/handle/unirio/11947. Acesso em: 11 abr. 2021.

VIANNA, O. Populações meridionais do Brasil. Rio de Janeiro: Paz e Terra, 1974.

WASHINGTON, L. Posição do bibliotecário. Correio Paulistano, São Paulo, ano 92, ed. 27411, p. 4, 03 ago. 1945. Disponível em:

http://memoria.bn.br/DocReader/090972_09/24530. Acesso em: 03 mar. 2020.

WEBER, M. A “ética” protestante e o espírito do capitalismo. São Paulo: Companhia das Letras, 1999.

WEBER, M. A política como vocação. In: WEBER, M. Ensaios de sociologia. Rio de Janeiro: LTC, 1982. 